$$
\text { DOE/ID/ } 13268-T 3
$$

ENVIRONMENTAL SCIENCE AND RESEARCH FOUNDATION REPORT SERIES, NUMBER 17

\title{
ENVIRONMENTAL SCIENCE AND RESEARCH FOUNDATION ANNUAL TECHNICAL REPORT: CALENDAR YEAR 1996
}

\author{
Edited by \\ Randall C. Morris and Roger D. Blew \\ July 1997 \\ O. Doyle Markham, Executive Director
}

\begin{abstract}
DISCLAIMER
This report was prepared as an account of work sponsored by an agency of the United States Government. Neither the United States Government nor any agency thereof, nor any of their employees, makes any warranty, express or implied, or assumes any legal liability or responsibility for the accuracy, completeness, or usefulness of any information, apparatus, product, or process disclosed, or represents that its use would not infringe privately owned rights. Reference herein to any specific commercial product, process, or service by trade name, trademark, manufacturer, or otherwise does not necessarily constitute or imply its endorsement, recommendation, or favoring by the United States Government or any agency thereof. The views and opinions of authors expressed herein do not necessarily state or reflect those of the United States Government or any agency thereof.
\end{abstract}




\section{DISCLAMIER}

Portions of this document may be illegible in electronic image products. Images are produced from the best available original document. 


\section{ENVIRONMENTAL SCIENCE AND RESEARCH FOUNDATION ANNUAL TECHNICAL REPORT JANUARY 1 - DECEMBER 31, 1996}

\section{EXECUTIVE SUMMARY}

This Annual Technical Report describes work conducted for the Department of Energy, Idaho Operations Office (DOE-ID), by the Environmental Science and Research Foundation (Foundation) under contract DE-AC07-94ID13268. The Foundation's mission to DOE-ID provides support in several key areas. We conduct an environmental monitoring and surveillance program over an area covering much of the upper Snake River Plain, and provide environmental education and support services related to Idaho National Engineering and Environmental Laboratory (INEEL) natural resource issues. Also, the Foundation, with its University Affiliates, conducts ecological and radioecological research on the Idaho National Environmental Research Park. This research benefits major DOE-ID programs including Waste Management, Environmental Restoration, Spent Nuclear Fuels, and Land Management Issues. The major accomplishments of the Foundation and its University Affiliates during the calendar year 1996 can be divided into five major categories.

\section{ENVIRONMENTAL SURVEILLANCE PROGRAM}

In this category, the Foundation and its University Affiliates:

- Routinely sampled air, water, soils, environmental dosimeters and various foodstuffs throughout the upper Snake River Plain for contaminants originating from the INEEL. During 1995, we collected 2,378 samples as part of the surveillance program, and performed 3,653 analyses on these samples.
- Completed construction and began routinely collecting data from two Community Monitoring Stations located at area schools.

- Prepared the INEEL Site Environmental Report for Calendar Year 1995. Also, we prepared and distributed a report that highlighted the significant data and conclusions from the annual site environmental report. This report was written for a more general audience than the full report and was titled, In Summary: Idaho National Engineering Laboratory Site Environmental Report for Calendar Year 1995.

- Developed or revised standard operating procedures for sample collection and preparation, safety, and quality assurance, and incorporated them into the controlled Environmental Science and Research Foundation Manual. The manual contains 40 plans and procedures including 5 new procedures for 1996.

- Continued to conduct routine quality assurance assessments of our internal programs as well as contractor analytical laboratories. These assessments ranged from informal "walkdowns" of selected field activities by the program manager to formal surveillances using a checklist by a designated quality assurance coordinator. A program to obtain and submit blind spiked samples (samples containing a known amount of radioactive material) to laboratories performing radiological analyses was also continued. 
- Obtained analytical services from independent laboratories including laboratories at Idaho State University, University of California at Davis, University of Toronto, and a commercial laboratory.

- Installed and began use of the new Sample and Environmental Analyses Management System (SEAMS) during 1996. This system allows surveillance program users to schedule samples, generate bar-code labels, and track samples from collection, through the analysis process, until final disposal. Analytical data received from the laboratories in electronic format can be loaded directly into the system.

\section{ENVIRONMENTAL EDUCATION}

In this category, the Foundation and its University Affiliates:

- Published six issues of Foundation Focus. Circulation of the newsletter grew $55 \%$ by the end of 1996 to 1,024 .

- Gave 49 presentations. The audiences included professional societies, INEEL tour groups, classrooms (from elementary through university graduate level), and others. We estimated that more than 1,500 people attended Foundation presentations.

- Prepared and issued 25 news releases to approximately 212 media outlets. Each month, Foundation activities related to INEEL were mentioned by news media across Idaho, with additional coverage in Montana, South Dakota, and Utah.

- Continued to operate a Travelers' Information Radio Station for the INEEL. This station provides information on INEEL environmental topics to passengers in vehicles traveling through the INEEL. Fourteen messages were aired in 1996. In order to supply future messages we conducted a radio script writing contest for area high school students. Sixteen students won awards.

- Made a portable display describing the INEEL Offsite Environmental Surveillance Program available to libraries and other public institutions throughout Idaho. It appeared at 11 locations in 1996.

- Published 10 Foundation reports. In addition, Foundation researchers had 20 technical, peer-reviewed articles and reports published, in-press, or submitted during 1996

\section{ENVIRONMENTAL SERVICES AND SUPPORT}

In this category, the Foundation and its University Affiliates:

- Responded to more than 250 requests for information from the public, DOE, DOE contractor personnel, scientists, and stakeholders regarding the Foundation's programs or the environmental contamination, radioecology, ecology, surveillance activities and natural resources at the INEEL.

- Conducted 37 field evaluations in support of NEPA at the INEEL. The Foundation has taken a leading role in monitoring compliance with requirements of Environmental Checklists during the progress of projects at the INEEL.

- Conducted two big-game surveys and one site-wide raptor count. We sent the results to appropriate agencies, including DOE, the Idaho Department of Fish and Game, and the U.S. National Biological Service.

- Established working relations with State and Federal resource management agencies on behalf of the INEEL. The Foundation continued as the INEEL interface with the U.S. Department of Agriculture Animal 
Damage Control programs and the U.S. Fish and Wildlife Service Threatened and Endangered Species program.

- Participated in INEEL meetings including several established group meetings, ad hoc committees, and singular meetings.

- Facilitated use of the Idaho National Environmental Research Park by 162 University scientists, staff, and graduate students. We provided technical review of INEEL research plans and management documents.

\section{ECOLOGICAL RISK ASSESSMENT}

The Foundation has served as a co-leader in the ecological risk assessment guidance development effort since its inception at the INEEL. This effort resulted in a guidance document for conducting screening-level ecological risk assessments on the INEEL. In 1996, the Foundation:

- Contributed to the development of techniques for conducting site-wide and WAG-wide ecological risk assessments.

- Participated in developing the Field Sampling Plan for the Site-wide Ecological Risk Assessment.

- Provided logistical support for two LMITCO summer interns to summarize the Foundation's reprint database with respect to it's relevance to ecological risk. Their report is in progress.

- Participated in a DOE-HQ sponsored working group to develop methodologies for incorporating the Data Quality Objectives process into the Ecological Risk Assessment process.

- Interacted regularly with other people involved in ecological risk assessment across the nation to discuss ideas and share solutions to ecological risk problems which are of interest across the DOE complex.

- Provided input to LMITCO on the thinking behind the proposed rule 10 CFR 834 , Subpart F.

In addition to these DOE-ID funded activities, the Foundation engaged in other activities related to ecological risk assessment on the INEEL.

- We participated, by invitation, in a DOEHQ sponsored "Working Meeting on improving the qualitative evaluation of environmental impacts at the DOE Environmental Management sites."

- We planned and conducted a survey of sensitive species at the INEEL Waste Area Groups.

\section{RESEARCH BENEFITTING THE DOE-ID MISSION}

In this category, the Foundation and its University Affiliates:

- Conducted 30 research projects. A total of 153 scientists, graduate students, and technicians from 12 universities and colleges participated in Foundation research projects at the INEEL. These projects supported DOE-ID programs for Waste Management, Environmental Restoration, Spent Nuclear Fuels, Land Management Issues, and other INEEL and DOE programs.

- Provided research data to DOE-ID for use in complying with various mandates and regulations including the National Environmental Policy Act; the Endangered Species Act; the Natural Resource Damage Assessment and Risk Assessment sections of the Comprehensive Environmental Response, Compensation, and Liability 
Act; and the Federal Noxious Weed Act.

- Prepared 20 technical manuscripts for peer-reviewed journals, 10 Foundation Technical Reports, and two articles in the popular literature.

- Presented research results at regional, national, and international scientific society meetings, as well as in university and other classroom environments. Other products of our research program included the design and manufacture of various electronic gauges to measure snowmelt runoff, predictive models and GIS maps of snake hibernacula, various computerized databases of plants and animals on the INEEL, and significant additions of specimens to lichen and invertebrate museum collections.

Overall, the Foundation was productive and efficient while under contract to DOE-ID during 1996. Most of the goals of each individual program were accomplished, and the Foundation's responses to requests from DOE-ID and INEEL contractors were timely, complete, and cost effective. 


\section{TABLE OF CONTENTS}

EXECUTIVE SUMMARY $\ldots \ldots \ldots \ldots \ldots \ldots \ldots \ldots \ldots \ldots \ldots \ldots \ldots \ldots \ldots \ldots \ldots \ldots \ldots$

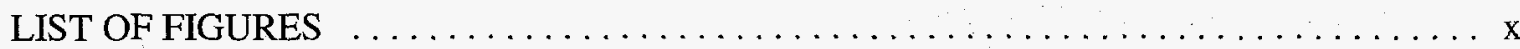

LIST OF TABLES $\ldots \ldots \ldots \ldots \ldots \ldots \ldots \ldots \ldots \ldots \ldots \ldots \ldots \ldots \ldots \ldots \ldots \ldots \ldots \ldots$

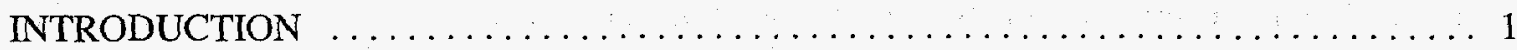

Section I. INEEL OFFSITE ENVIRONMENTAL SURVEILLANCE PROGRAM $\ldots \ldots \ldots 4$

Section II. ENVIRONMENTAL EDUCATION $\ldots \ldots \ldots \ldots \ldots \ldots \ldots \ldots \ldots \ldots \ldots \ldots \ldots \ldots \ldots$

Section III. ENVIRONMENTAL SERVICES AND SUPPORT $\ldots \ldots \ldots \ldots \ldots \ldots \ldots 22$

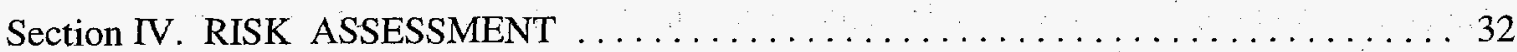

Section V. RESEARCH BENEFITTING THE DOE-ID MISSION . . . . . . . . . . . 35

Wildlife Use of Man-made Ponds on the Idaho National Engineering and Environmental

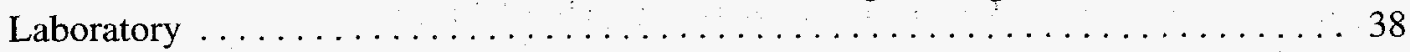

Breeding and Wintering Populations of Raptors on the Idaho National Engineering and

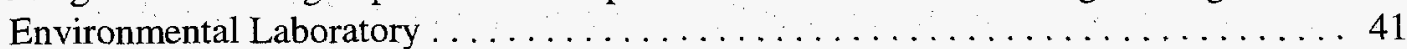

Comparison of Four Protective Cap Designs for Burial of Hazardous Waste at the Idaho

National Engineering and Environmental Laboratory $\ldots \ldots \ldots \ldots \ldots \ldots \ldots . \ldots 4$

Mitigating Long Term Impacts of Small Mammal Burrowing on the Closure of Hazardous

Waste Areas . . . . . . . . . . . . . . . . . . . . . 52

Studies on the Effectiveness of Biobarriers Against Harvester Ant Excavation of Buried

Waste: Laboratory Experiments . . . . . . . . . . . . . . . . 55

Studies on the Effectiveness of Biobarriers Against Harvester Ant Excavation of Buried

Waste: Establishment of Ant Colonies on the Protective Cap/Biobarrier Field Plots . . 61

Soil Subsidence and Snowmelt Erosion on Waste Disposal Sites . . . . . . . . . 66

Distribution, Abundance, and Habitat of the Pygmy Rabbit on the Idaho National Engineering

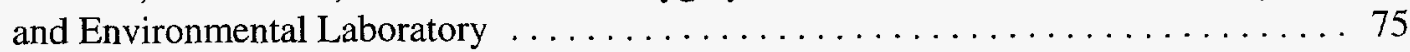

Heavy Metals in Small Mammal Populations at the Idaho National Engineering and

Environmental Laboratory . . . . . . . . . . . . . . . . . . . 82

Long-term Vegetation Dynamics at the Idaho National Engineering and Environmental

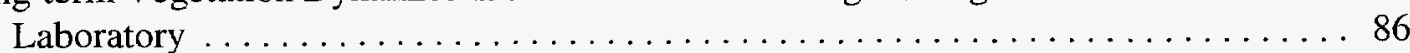

Habitat Use and Movement Patterns of Mule Deer on the INEEL . . . . . . . . . . 94

Plutonium Distribution among Soil Phases Around the Subsurface Disposal Area at the Idaho

National Engineering and Environmental Laboratory $\ldots \ldots \ldots \ldots \ldots \ldots \ldots$

Lichens as Air Pollution Biomonitors at the Idaho National Engineering and Environmental

Laboratory . . . . . . . . . . . . . . . . . . . . . . 100

Breeding Bird Surveys at the Idaho National Engineering and Environmental Laboratory 103 
Monitoring Amphibian and Reptile Populations on the Idaho National Engineering and Environmental Laboratory: Indicators of Environmental Health and Change . . . . 107

Honey Bees as Sentinels of Environmental Hazards at the Idaho National Engineering and

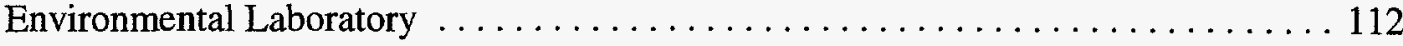

Diversity of the Ant Fauna at the Idaho National Engineering and Environmental Laboratory:

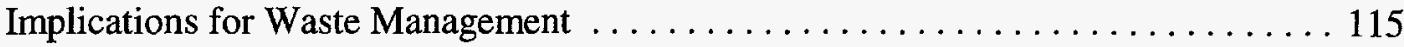

Radionuclide Cycling in Plastic Lined Evaporation Ponds and Effects on Radionuclide Levels in and Radiation Doses to Waterfowl and Waterfowl Hunters . . . . . . . . . . . . 118

Radioecology of Iodine-129 in the Sagebrush Steppe Ecosystern . . . . . . . . . . . 127

Surface Water Penetration at the Subsurface Disposal Area . . . . . . . . . . . . . 131

Occurrence of Small Owl Species on the Idaho National Engineering and Environmental

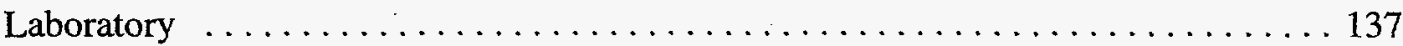

Factors That Affect the Distribution of Soil Lichens at the Idaho National Engineering and

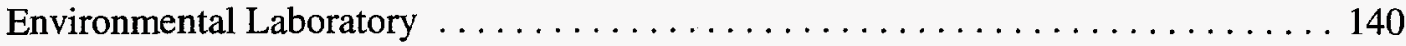

Fire Ecology of the Idaho National Engineering and Environmental Laboratory . . . . . 144 Offsite Transport of Radionuclides from INEEL Facilities by, and Effects to,

Barn Swallows . . . . . . . . . . . . . . . . . . . . . 151

Uptake of Contaminants by Vegetation and Burrowing Activity on a Decommissioned Radioactive Waste Pond Complex . . . . . . . . . . . . . . . . . . . . 154

Ecological Impacts of Irrigating Native Vegetation with Sewage Wastewater . . . . . . 159

Noxious and Exotic Weed Survey of the Idaho National Engineering and Environmental

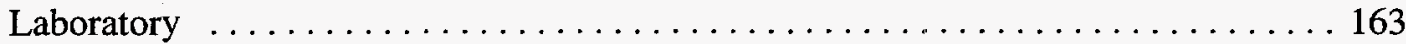

Habitat Use by Summer Populations of Bats in Sagebrush Steppe . . . . . . . . . 168

Trace Elements and Organics in Surface Soils at the Subsurface Disposal Area . . . . . 175 Uptake Parameters of Contaminants and Species Important to INEEL Ecological Risk

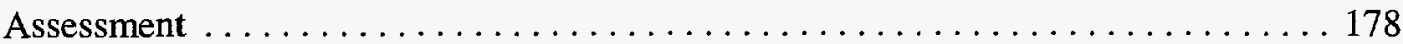

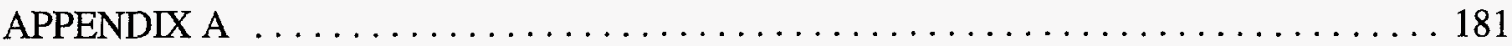

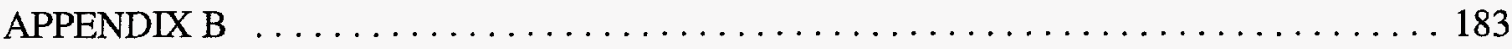

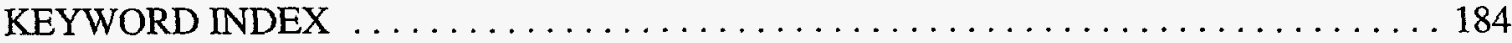




\section{LIST OF FIGURES}

Fig. 1. Air, drinking water, and surface water sampling locations for the INEEL Offsite

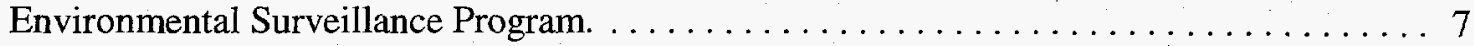

Fig. 2. Soil and foodstuff sampling locations for the INEEL Offsite Environmental Surveillance

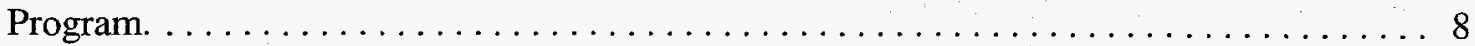

Fig. 3. Top: Evapotranspiration for the 1996 growing season for four cap designs, two vegetation types, and three irrigation treatments from the Protective Cap/Biobarrier Experiment at the INEEL. ET was calculated by subtracting total soil water content on 1 November from that on 22 March and adding precipitation received and irrigation applied between those dates. Data are means for Replicates 1 and 2. Bottom: Total soil water content in the upper $1 \mathrm{~m}$ of soil for the four cap configurations and two vegetation types under ambient precipitation and the summer irrigation treatment on 1 November 1996. Analyses are

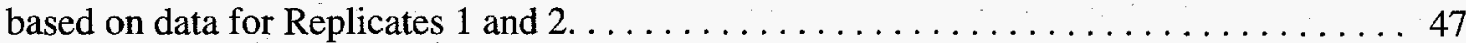

Fig. 4. Changes in soil moisture over the 1996 growing season for a 1-m biobarrier cap and a 0.5-m biobarrier cap. In both cases, the moisture profiles indicate extraction of water by plants from the soil below the biobarrier. $\ldots \ldots \ldots \ldots \ldots \ldots \ldots \ldots \ldots \ldots \ldots \ldots$

Fig. 5. Pre-dawn water potentials of selected Artemisia tridentata ssp. tridentata and A.t. ssp. wyomingensis in ambient precipitation plots of Replicates 1 and 3 during the 1996 growing season. Bars are standard errors. Significant differences $(\mathrm{P}<0.5)$ on a sampling date are

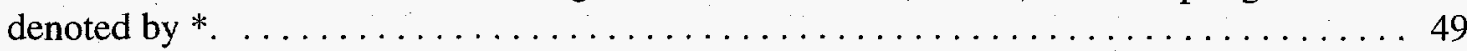

Fig. 6. Schematic of the nest structure used in laboratory testing of potential biobarriers for the exclusion of Pogonomyrmex salinus during nest excavation. . . . . . . . . . . 57

Fig. 7. Treatment configurations used in laboratory ant nest structures in 1996. Stippling indicates gravel and elliptical shapes cobble. Blank areas were filled with soil. Each section

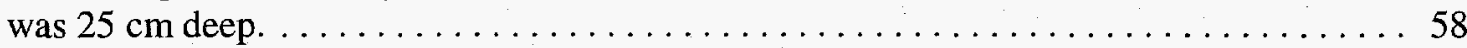

Fig. 8 1995-1996 time to exhumation of tracer gravel from $25-\mathrm{cm}, 50-\mathrm{cm}, 75-\mathrm{cm}$, and $100-\mathrm{cm}$ depths after addition of ants to column. . . . . . . . . . . . . . . . . . 59

Fig. 9 1992-1993 time to exhumation of tracer gravel from $25-\mathrm{cm}, 50-\mathrm{cm}, 75-\mathrm{cm}$, and $100-\mathrm{cm}$ depths after addition of ants to column. . . . . . . . . . . . . . . . . . . . 60

Fig. 10. Location of transplanted harvester ant nests on the Protective Cap/Biobarrier Experiment.

Fig. 11. Surface/contour map of the PC/BE taken during the growing and dormant seasons, 1996 $(\mathrm{n}-350)$. North and east coordinate horizontal distances are in feet. North coordinate axis is slightly exaggerated.

Fig. 12. Comparison of cumulative snow melt runoff for predicted (Tarboton 1994) and measured during the complete snow season in 1996. Interrill erosion is measured from simulated waste burial trench caps near EBR-1 at INEEL. . . . . . . . . . . . . .

Fig. 13. Comparison of cumulative snow melt runoff for predicted (Tarboton 1994) and measured during the spring snow melt period only in 1996. Interrill erosion is measured from

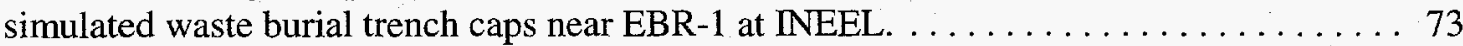

Fig. 14. Mean "tall" shrub height of five point quarter sample grids around burrow sites. . . 78

Fig. 15. Mean "short" shrub density of five point quarter sample grids around burrow sites. . 79

Fig. 16. Daily activity patterns of a male pygmy rabbit, based on the average number of pulse changes for every half hour interval within a 24-hour block Analysis was based on five 24hour blocks. . . . . . . . . . . . . . . . . . . . . . . . . . . 80 
Fig. 17. Daily activity patterns of a female pygmy rabbit, based on the average number of pulse changes for every half hour interval within a 24-hour block Analysis was based on five 24hour blocks. . . . . . . . . . . . . . . . . . . . . . . . . . . . . . 81

Fig. 18. Relative cover of big sagebrush (Artemisia tridentata; ARTR), green rabbitbrush (Chrysothamnus viscidiflorus), and perennial grasses on 35 permanent vegetation plots at the Idaho National Engineering and Environmental Laboratory. . . . . . . . . . . 88

Fig. 19. Mean cover of perennial grasses plotted against mean cover of shrubs for 35 permanent plots at the Idaho National Engineering and Environmental Laboratory. Regression lines are drawn for those years in which there was a significant $(\mathrm{P}<0.05)$ linear relationship between perennial grass and shrub cover. . . . . . . . . . . . . . . . . . . . . . . 89

Fig. 20. Perennial grass cover plotted against perennial grass species richness for nine census years on permanent plots at the Idaho National Engineering and Environmental Laboratory. Each point represents one plot.

Fig. 21. Shrub cover plotted against shrub species richness for nine census years on permanent plots at the Idaho National Engineering and Environmental Laboratory. Each point represents one plot. Regression lines are drawn for those years in which there was a significant $(\mathrm{P}<0.05)$ linear relationship between cover and species richness. . . . . . . . . . . . . . 91

Fig. 22. Results of a search for rattlesnake dens based on the predictive model. Out of the 50 predicted sites searched, 34 were not dens, 9 were possible dens, 5 were probable dens, and 2 were confirmed dens. None of the non-predicted areas exhibited snake activity. . . . . 110

Fig. 23. Total and major radionuclide concentrations in the water column of the east evaporation

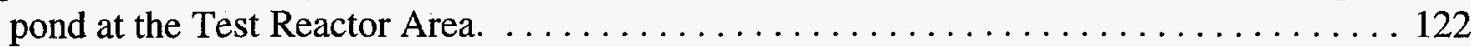

Fig. 24. Total and major radionuclide concentrations in the water column of the west evaporation pond at the Test Reactor Area.

Fig. 25. Total radionuclide concentrations in the muscle tissue of both control ducks and ducks using waste ponds on the INEEL. Ducks were collected in both 1995 and $1996 . \ldots \ldots 125$

Fig. 26. Map of the Idaho National Engineering and Environmental Laboratory showing the locations of 15 sites where environmental samples were collected for ${ }^{129} \mathrm{I}$ analysis. Locations are indicted by $\mathrm{S}$; the control location was located south of Highway 20 between Idaho Falls and the eastern boundary of the INEEL. . . . . . . . . . . . . . . . . . . . 129

Fig. 27. Volumetric water content (\%) at 20-cm depth increments on specific dates in 1996 in eight areas of different waste cover treatments in the Radioactive Waste Management Complex at the Idaho National Engineering and Environmental Laboratory. Plot codes are

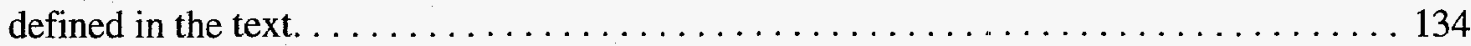

Fig. 28. Total volumetric water content (\%) in areas of different waste cover treatments in the Radioactive Waste Management Complex at the Idaho National Engineering and Environmental Laboratory. Water contents are given at peak recharge (spring) and maximum depletion (fall) from 1988 - 1996. Plot codes are defined in the text. . . . . . . . . . . 135

Fig. 29. Locations (*) of spotted knapweed, field bindweed, leafy spurge, and Canada thistle

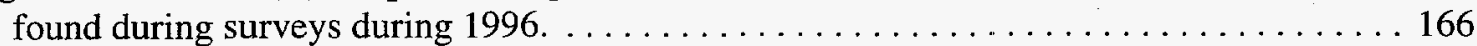

Fig. 30. Locations (*) of infestations of musk thistle found during 1996. Dashed line indicates

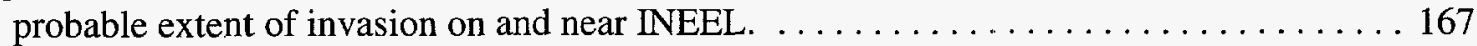

Fig. 31. A diagram of the experimental apparatus to determine the plant-soil concentration ratios

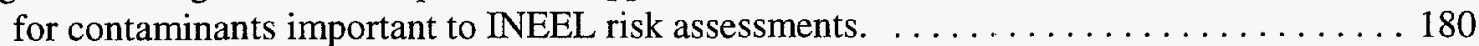




\section{LIST OF TABLES}

Table 1. Summary of the Foundation environmental surveillance program (1996) . . . . . . 6

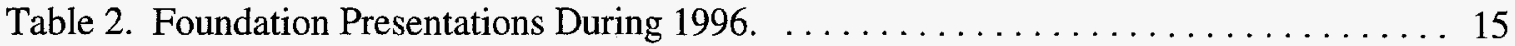

Table 3. Foundation Signs, Posters, and Displays During 1996. . . . . . . . . . . . . 18

Table 4. Foundation Reports Published During 1996. . . . . . . . . . . . . . . . . 20

Table 5. NEPA Field Evaluations conducted by the Environmental Science \& Research

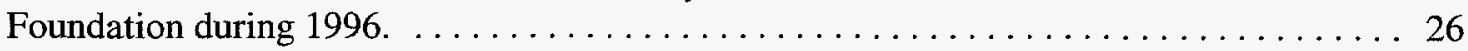

Table 6. Listed Threatened and Endangered Species and Other Species of Concern Possibly

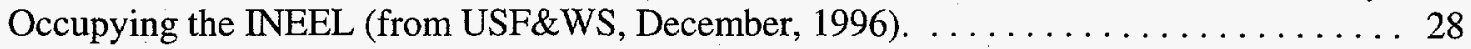

Table 7. Number of birds of prey observed on the INEEL during the 1996 winter raptor survey.

Table 8. DOE-ID Program Beneficiaries of Specific Environmental Science and Research Foundation Research Projects. . . . . . . . . . . . . . . . . . . . . 36

Table 9. 1996 Assignment of ant colonies to columns and treatments, colony size (number of workers) collected in the field and eventual number added to the columns. Treatments: BB25 $=10-30-10-\mathrm{cm}$ thicknesses of gravel-cobble-gravel placed at a depth of $25-75 \mathrm{~cm}, \mathrm{BB} 50=10-$ $30-10-\mathrm{cm}$ thicknesses of gravel-cobble-gravel placed at a depth of $50-100 \mathrm{~cm} . \ldots \ldots \ldots 59$

Table 10. General nest data. See Fig. 1 for nest placement. . . . . . . . . . . . . 64

Table 11. Afternoon colony activity of established nests in biobarrier plots as of 19 August and 24 September 1996. . . . . . . . . . . . . . . . . . . . . . . . . 65

Table 12. Summary of rainfall simulation plot characteristics and results. $\ldots \ldots \ldots \ldots \ldots 70$

Table 13. Concentrations of selected radionuclides in filtered water, seston (particulate matter), and sediment from the lined evaporation ponds and the formerly used percolation ponds at

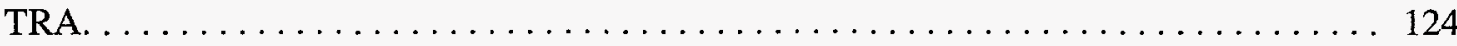

Table 14. Average total concentrations of radionuclides in the edible portion of ducks collected from waste ponds on the INEEL and the whole body committed effective dose to a human

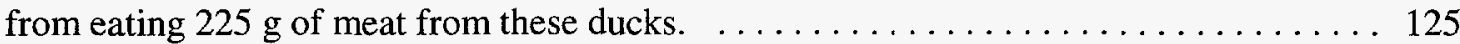

Table 15. Annual percentage of average precipitation ( $99.7 \mathrm{~mm}$ water equivalent) falling during the non-growing season (October through March) at the INEEL, maximum depth of recorded infiltration (recharge), and average spring maximum and fall minimum volumetric soil water content on all study plots at the Subsurface Disposal Area. . . . . . . . . . . . . 133

Table 16. Cover (\%) of common plant species on the Floyd plots burned by the Butte City Fire

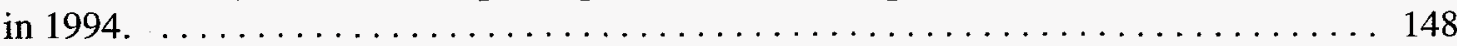

Table 17. Nitrate and ammonia concentrations ( $\mu \mathrm{g} \mathrm{N} / \mathrm{g}$ soil) for soils collected from near shrubs (shrub space) and from interspaces between shrubs on an area burned by the 1995 Argonne West fire and an adjacent unburned area. Initial values are for samples analyzed immediately after they were collected; final values are for samples incubated in the laboratory for six weeks. Statistical tests for $\mathrm{NH}_{4}$ and $\mathrm{NO}_{3}$ samples were performed on ln-transformations for analysis of variance. Arithmetic means are reported in all cases. . . . . . . . . . . . . 149

Table 18. Average exposure rates measured in barn swallow nests at various sites, 1995 and

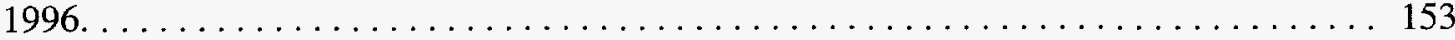

Table 19. Average dry biomass per square meter for species found growing on the soil covers of

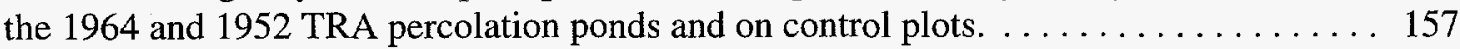

Table 20. Average concentrations of selected radionuclides in vegetation growing on the soil covers of the 1964 and 1952 TRA percolation ponds and on control plots. . . . . . . . 158 
Table 21. Vegetation percent cover in the three different plant communities irrigated with wastewater and similar control areas.

Table 22. Types of summer bat roosts located in INEEL lava tube caves determined by day

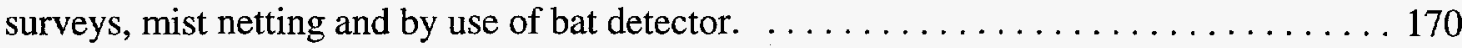

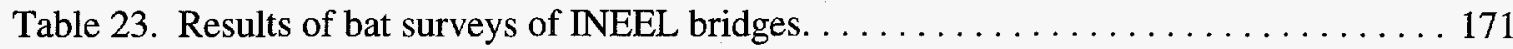

Table 24. INEEL Central Facilities Area buildings used as bat roosts. . . . . . . . . 172

Table 25. Results of bat detector transects in juniper and sagebrush dominated areas and along the Big Lost River.

Table 26. Results of bat surveys of human-made ponds on the INEEL. A "pass" means one or more individuals were detected flying over or near water. A "feeding buzz" indicates that one or more individuals were hunting insects. 


\section{ENVIRONMENTAL SCIENCE AND RESEARCH FOUNDATION \\ ANNUAL TECHNICAL REPORT \\ JANUARY 1 - DECEMBER 31, 1996}

\section{INTRODUCTION}

This Annual Technical Report is submitted to the Department of Energy, Idaho Operations Office (DOE-ID), by the Environmental Science and Research Foundation, Inc. in accordance with contract DE-AC07-94ID13268. This report summarizes the major activities conducted for DOE-ID by the Environmental Science and Research Foundation during the period January 1 through December 31, 1996. Because universities are involved in almost all Foundation activities, in this report the term "Foundation" collectively refers to Foundation Staff and Foundation University Affiliates.

The Environmental Science and Research Foundation designed this Annual Technical Report to be readable and meaningful to DOE-ID and the general public. We made efforts to reduce the occurrence of scientific terminology and detailed descriptions of specific experimental and statistical design. The Foundation manages, coordinates, and conducts ecological and environmental research, environmental surveillance, environmental services, and environmental education for DOE-ID at the Idaho National Engineering and Environmental Laboratory (INEEL). The Foundation's staff has more than 80 years combined experience in conducting these activities at the INEEL. By using University Affiliates and university and commercial analytical laboratories, and by operating as a private, non-profit organization, the Foundation obtains facts independent from Management \& Operating contractor. This provides independent data analyses and reports which help to satisfy concerns expressed by the State of Idaho and its citizens. Additionally, this approach is consistent with DOE's commitment to public openness.
To meet these obligations to DOE-ID and the public, the Foundation has established several principal goals. These goals form the basis for the five major sections of this report.

\section{SECTION I: INEEL OFFSITE ENVIRONMENTAL SURVEILLANCE PROGRAM}

The Foundation conducted surveillance to satisfy the environmental protection program requirements of DOE Order 5400.1 which assure compliance with environmental laws and regulations, executive orders, and DOE policies. Section I describes the offsite environmental surveillance program and summarizes the sampling effort. This summary indicates the types, frequency, and location of routine environmental samples, and the constituents for which each sample was analyzed. This section does NOT provide analysis or interpretation of the program data for 1996. Analysis and interpretation will be presented in a separate report (The Idaho National Engineering Laboratory Annual Site Environmental Report for Calendar Year 1996), available in August 1997.

\section{SECTION II: ENVIRONMENTAL EDUCATION}

Through its educational mission, the Foundation aims to improve public understanding of the environment of the INEEL. Section II of this report emphasizes the Foundation's support of DOE-ID's open and frank discussion of environmental issues with various individuals and stakeholder groups. The Foundation's Environmental Education program includes an aggressive agenda of press releases, newsletters, and presentations to both technical and nontechnical audiences. 
SECTION III: ENVIRONMENTAL SERVICES AND SUPPORT

Ecological and natural resource related information is vital not only for the completion of environmental compliance documentation, but also for the day-to-day management at the INEEL. Section III summarizes the Foundation's activities regarding natural resource issues on the INEEL. The Foundation provided DOE-ID with information and recommendations for wildlife and other ecological concerns on the INEEL. We served as the point of contact for DOE-ID on natural resource issues with various agencies (e.g., Bureau of Land Management and the Idaho Department of Fish and Game). In addition, the Foundation responded to public and professional inquiries about the ecology of the INEEL.

\section{SECTION IV: ECOLOGICAL RISK ASSESSMENT}

The Environmental Protection Agency (EPA), under the Comprehensive Environmental Response, Compensation, and Liability Act (CERCLA) requires that all Superfund sites perform both human health and ecological risk assessments. In addition, the Action Plan for Implementing the Federal Facility Agreement and Consent Order (FFA/CO) for the INEEL requires developing risk assessment guidance for the entire INEEL site. Section IV describes the Foundation's involvement in ecological risk assessment issues and efforts, both locally and nationally. This program provides DOE-ID with the basic tools to comply with various federal and state regulations, mandates, and agreements.

\section{SECTION V: ECOLOGY AND RADIOECOLOGY RESEARCH}

At the INEEL, the Foundation develops scientific goals and conducts environmental research consistent with the needs of DOE-ID. Section V summarizes the various radioecology and ecology research projects conducted by Foundation staff and University Affiliates on the INEEL. This research provided sound, scientifically-defensible answers to basic and applied ecological questions related to DOE-ID programs including Waste Management, Environmental Restoration, Spent Fuels, and Infrastructure. The knowledge gained from this research is the basis for the environmental education, services and support supplied by the Foundation to DOE-ID and the INEEL community.

\section{CONTRIBUTORS}

This Annual Technical Report was a collective effort of Foundation staff and University Affiliates. Foundation contributors included R. D. Blew, R. W. Brooks, O. D. Markham, R. G. Mitchell, R. C. Morris, D. S. Peterson, T. D. Reynolds, D. E. Roush, and R. W. Warren. The University Affiliates contributing to this report included Principal Investigators J. J. Bromenshenk (University of Montana); L. D. Flake (South Dakota State University); J. E. Anderson, J. W. Laundré, B. D. Eshelman, and C. R. Peterson (Idaho State University); W. H. Clark (Albertson College of Idaho); J. B. Johnson, P. E. Blom, and J. M. Peek (University of Idaho);

S. A. Ibrahim (Colorado State University);

L. C. Pearson (Ricks College, retired);

D. S. Rogers (Brigham Young University); W. P. MacKay (University of Texas at El Paso); J. R. Belthoff (Boise State University); and J. P. Dobrowolski (Utah State University); Research Associate G. C. Smith (University of Montana); Research Assistants T. D. Ratzlaff and E. K. Duffin (Idaho State University); and M. D. Gaglio, E. A. Osorio, and I. Iniquez (University of Texas at $\mathrm{El}$ Paso); and Graduate Students T. J. Christian (University of Montana); S. L. Cooper, K. I. Gabler, L. T. Heady, M. Miller, 
D. Evans, and S. Patrick (Idaho State University); N. A. Fahler (South Dakota State

University); S. Haymond (Brigham Young
University); and D. E. Beaver (University of Idaho) 


\title{
SECTION I
}

\section{INEEL OFFSITE ENVIRONMENTAL SURVEILLANCE PROGRAM}

\begin{abstract}
The Environmental Science and Research Foundation conducted the Idaho National Engineering and Environmental Laboratory (INEEL) Offsite Environmental Surveillance Program for DOE-ID during 1996. Results from 2378 samples collected during the year consisting of 3653 analyses (perforrned by four offsite analytical laboratories) indicated that radioactivity from the INEEL could not be distinguished from natural radioactivity and worldwide fallout in the vicinity of the INEEL. We prepared the Idaho National Engineering Laboratory Site Environmental Report for Calendar Year 1995 and quarterly reports of environmental surveillance program data. A number of presentations and displays related to the environmental surveillance program were provided throughout Idaho, with an emphasis on eastern Idaho. We continued to develop a high-quality surveillance program by review and revision of procedures and methodologies, installation of a computerized sample/data management system, and analysis of a variety of quality control samples to verify our contracted laboratories' precision and accuracy. By the end of the year, two community monitoring stations were installed, and now serve as educational tools for teaching about environmental surveillance at the INEEL.
\end{abstract}

Keywords: Air, community monitoring stations, drinking water, environmental dosimetry, environmental surveillance, foodstuffs, surface water, quality assurance.

\section{JUSTIFICATION}

Operations at the Idaho National Engineering and Environmental Laboratory (INEEL) have the potential to release both radioactive and nonradioactive contaminants into the air and water. To assess the effects of these contaminants, the Environmental Science and Research Foundation conducted the INEEL Offsite Environmental Surveillance Program for the Department of Energy, Idaho Operations Office (DOE-ID).

The program's primary purposes were to sample media representing pathways of contaminants from the INEEL to the public, to obtain radiological analyses for these samples, and to report and interpret the results of these analyses for the public. The Foundation conducted surveillance to satisfy the environmental protection program requirements of DOE Order 5400.1 which assure compliance with environmental laws and regulations, executive orders, and DOE policies. We compared the data to derived concentration guides established for protection of members of the public and the environment in DOE Order 5400.5.

\section{Program Goals and Objectives}

The Foundation's major goals for the INEEL Offsite Environmental Surveillance Program were to:

- Sample and analyze media from all relevant contaminant (primarily radionuclides) pathways to the offsite environment.

- Evaluate results of offsite environmental surveillance data and coordinate with other agencies performing environmental monitoring both on and offsite, including INEEL contractors and federal and state organizations.

- Collect the necessary data to verify that INEEL operations are in compliance with applicable environmental standards and assess the offsite impact, if any, of INEEL operations on humans and the environment.

- Report and interpret environmental surveillance results obtained by the Foundation, Lockheed-Martin Idaho Technologies Company (LMITCO), the National Oceanic and Atmospheric 
Administration, the United States

Geological Survey, and other agencies to

DOE-ID and the public.

- Promote public awareness of the surveillance program and its results, and provide opportunities for public comment on environmental surveillance issues at the INEEL.

In order to achieve these goals, we established the following objectives for 1996:

- Conduct a routine surveillance program to sample media representing potential exposure pathways for contaminants from the INEEL.

- Prepare technical reports that present and interpret environmental surveillance data for the DOE and the public, including the Idaho National Engineering Laboratory Site Environmental Report for Calendar Year 1995 and quarterly environmental surveillance reports.

- Continue to develop and implement a quality assurance program to ensure the Environmental Surveillance Program produces quality results and is operated in a manner consistent with requirements.

- Complete installation of two community monitoring stations, train station managers on operation of the samplers and equipment, and begin using data generated by the stations for classroom activities.

- Continue to evaluate the Offsite Environmental Surveillance Program through periodic review of data, procedures, and methodologies.

- Provide environmental surveillance program data, and interpretation of this data, to the public through periodic reports, news releases, the Foundation Focus newsletter, and public presentations.

- Complete installation of a computerized sample/data management system that allows samples to be tracked from collection through disposal, and train surveillance staff members on the use of the system.

\section{PROGRAM ACCOMPLISHMENTS}

The Foundation conducted the INEEL Offsite Environmental Surveillance Program for DOE-ID during 1996. The objectives described above were satisfied by major accomplishments in all aspects of the surveillance program.

\section{Routine Sampling Program}

A total of 2378 samples of air, water, foodstuffs, and environmental dosimeters were collected during 1996, and 3653 analyses were performed on these samples (Table 1). Of this total, quality control samples (replicates, duplicates, blanks, and spiked samples) accounted for 312 samples and 519 analyses.

A network of 14 low-volume air samplers (Fig. 1), including 11 at offsite locations and three on the INEEL, operated continuously throughout the year. An additional sampler located at the new Mountain View Middle School Community Monitoring Station in Blackfoot became operational at the beginning of October. Each week, filters were changed at all locations, and screening analyses were performed $\left({ }^{131} \mathrm{I}\right.$ for charcoal cartridges, gross alpha and gross beta for particulate filters).

Quarterly composites of the weekly filters were analyzed for gamma-emitting radionuclides, and selected locations were 
Table 1. Summary of the Foundation environmental surveillance program (1996).

\begin{tabular}{|c|c|c|c|c|c|}
\hline \multirow{2}{*}{$\begin{array}{l}\text { Sample Type } \\
\text { Analysis }\end{array}$} & \multirow{2}{*}{$\begin{array}{l}\text { Collection } \\
\text { Frequency }\end{array}$} & \multirow{2}{*}{$\begin{array}{l}\text { Number } \\
\text { of } 1996 \\
\text { Analyses }\end{array}$} & \multicolumn{3}{|c|}{ Locations } \\
\hline & & & Distant & Boundary & INEEL \\
\hline \multicolumn{6}{|l|}{ Air } \\
\hline $\begin{array}{r}\text { Gross Alpha } \\
\text { Gross Beta } \\
{ }^{131} \mathbf{I}\end{array}$ & weekly & $\begin{array}{l}897 \\
897 \\
857 \\
\end{array}$ & $\begin{array}{l}\text { Blackfoot, Craters of the Moon, } \\
\text { Idaho Falls, Rexburg, Mountain } \\
\text { View Middle School (Blackfoot) }\end{array}$ & $\begin{array}{l}\text { Arco, Atomic City, FAA Tower, } \\
\text { Howe, Monteview, Mud Lake, Reno } \\
\text { Ranch }\end{array}$ & $\begin{array}{l}\text { Main Gate, EFS, } \\
\text { Van Buren }\end{array}$ \\
\hline $\begin{array}{r}\text { Gamma Spec } \\
\text { Particulate } \\
\text { Mass }\end{array}$ & quarterly & $\begin{array}{l}76 \\
73\end{array}$ & $\begin{array}{l}\text { Blackfoot, Craters of the Moon, } \\
\text { Idaho Falls, Rexburg, Mountain } \\
\text { View Middle School (Blackfoot) }\end{array}$ & $\begin{array}{l}\text { Arco, Atomic City, FAA Tower, } \\
\text { Howe, Monteview, Mud Lake, Reno } \\
\text { Ranch. }\end{array}$ & $\begin{array}{l}\text { Main Gate, EFS, } \\
\text { Van Buren }\end{array}$ \\
\hline $\begin{array}{r}{ }^{90} \mathrm{Sr} \\
\text { Transuranics }\end{array}$ & quarterly & $\begin{array}{l}29 \\
30\end{array}$ & Rotating schedule & Rotating schedule & $\begin{array}{l}\text { Rotating } \\
\text { schedule }\end{array}$ \\
\hline \multicolumn{6}{|l|}{ IMPROVE } \\
\hline air visibility & semi-weekly & 106 & None & None & CFA \\
\hline \multicolumn{6}{|l|}{ PM-10 } \\
\hline fine particulates & every 6 days & 26 & $\begin{array}{l}\text { Rexburg, Mountain View Middle } \\
\text { School (Blackfoot) }\end{array}$ & None & None \\
\hline \multicolumn{6}{|l|}{ Air Moisture } \\
\hline Tritium & $\begin{array}{l}\text { four to } 13 \\
\text { weeks }\end{array}$ & 13 & Idaho Falls, Rexburg & Atomic City & None \\
\hline \multicolumn{6}{|l|}{ Precipitation } \\
\hline Tritium & monthly & 20 & Idaho Falls & None & CFA \\
\hline Tritium & weekly & 18 & None & None & EFS \\
\hline \multicolumn{6}{|l|}{ Surface $\mathrm{H}_{2} \mathrm{O}$} \\
\hline $\begin{array}{r}\text { Gross Alpha, } \\
\text { Gross Beta } \\
{ }^{3} \mathrm{H} \\
\end{array}$ & semiannually & $\begin{array}{l}19 \\
19 \\
19 \\
\end{array}$ & $\begin{array}{l}\text { Twin Falls, Buhl, Hagerman } \\
\text { Idaho Falls, Bliss }\end{array}$ & None & None \\
\hline \multicolumn{6}{|l|}{ Drinking $\mathrm{H}_{2} \mathrm{O}$} \\
\hline $\begin{array}{r}\text { Gross Alpha } \\
\text { Gross Beta } \\
{ }^{3} \mathrm{H} \\
\end{array}$ & semiannually & $\begin{array}{l}34 \\
34 \\
34\end{array}$ & $\begin{array}{l}\text { Aberdeen, Blackfoot, Carey, } \\
\text { Idaho Falls, Fort Hall, Minidoka, } \\
\text { Roberts, Shoshone }\end{array}$ & $\begin{array}{l}\text { Arco, Atomic City, Howe, } \\
\text { Monteview, Mud Lake }\end{array}$ & None \\
\hline \multicolumn{6}{|l|}{ Milk } \\
\hline${ }^{131} \mathrm{I}$ & monthly & 100 & $\begin{array}{l}\text { Blackfoot, Carey, Dietrich, } \\
\text { Minidoka, Roberts }\end{array}$ & Howe, Terreton, Arco & None \\
\hline $\begin{array}{l}\text { Tritium } \\
{ }_{90}^{0} \mathrm{Sr}\end{array}$ & annually & $\begin{array}{c}9 \\
10 \\
10\end{array}$ & $\begin{array}{l}\text { Blackfoot, Carey, Dietrich, Idaho } \\
\text { Falls, Minidoka, Roberts }\end{array}$ & Howe, Terreton, Arco & None \\
\hline${ }^{129} \mathrm{I}$ & quarterly & 20 & Blackfoot, Roberts & Howe, Terreton, Arco & None \\
\hline \multicolumn{6}{|l|}{ Potatoes } \\
\hline Gamma Spec & annually & $\begin{array}{l}6 \\
6 \\
\end{array}$ & Blackfoot, Idaho Falls, Rupert & Arco, Mud Lake & None \\
\hline \multicolumn{6}{|l|}{ Wheat } \\
\hline Gamma Spec & annually & $\begin{array}{l}12 \\
12\end{array}$ & $\begin{array}{l}\text { American Falls, Blackfoot, } \\
\text { Dietrich, Idaho Falls, Minidoka, } \\
\text { Carey }\end{array}$ & $\begin{array}{l}\text { Arco, Morteview, Mud Lake, Tabor, } \\
\text { Terreton }\end{array}$ & None \\
\hline \multicolumn{6}{|l|}{ Lettuce } \\
\hline $\begin{array}{r}\text { Gamma Spec } \\
{ }_{90} \mathrm{Sr}\end{array}$ & annually & $\begin{array}{l}9 \\
9 \\
\end{array}$ & $\begin{array}{l}\text { Blackfoot, Carey, Idaho Falls, } \\
\text { Pocatello }\end{array}$ & Arco, Atomic City, Howe, Mud Lake & None \\
\hline \multicolumn{6}{|l|}{ Fish } \\
\hline \multicolumn{6}{|l|}{ Sheep } \\
\hline Gamma Spec & annually & 18 & Blackfoot. & None & $\begin{array}{l}\text { INEEL grazing } \\
\text { areas }\end{array}$ \\
\hline \multicolumn{6}{|l|}{ Waterfowl } \\
\hline $\begin{array}{r}\text { Gamma Spec } \\
{ }_{90}^{90} \\
\text { Transuranics } \\
\end{array}$ & annually. & $\begin{array}{l}39 \\
24 \\
24 \\
\end{array}$ & Fort Hall & None & $\begin{array}{l}\text { Waste disposal } \\
\text { ponds }\end{array}$ \\
\hline \multicolumn{6}{|l|}{ Game } \\
\hline Gamma Spec & variable & 24 & None & None & INEEL roads \\
\hline \multicolumn{6}{|l|}{ Soil } \\
\hline $\begin{array}{r}\text { Gamma Spec } \\
{ }_{90}^{90} \mathbf{S r} \\
\text { Transuranics } \\
\end{array}$ & biennially & $\begin{array}{l}25 \\
12 \\
12 \\
\end{array}$ & $\begin{array}{l}\text { Carey, Crystal Ice Caves, } \\
\text { Blackfoot, St. Anthony }\end{array}$ & $\begin{array}{l}\text { Butte City, Monteview, Atomic City, } \\
\text { FAA Tower, Howe, Mud Lake (2), } \\
\text { Reno Ranch }\end{array}$ & None \\
\hline \multicolumn{6}{|l|}{ TLDs } \\
\hline $\begin{array}{r}\text { Gamma } \\
\text { Radiation }\end{array}$ & semiannual & 26 & $\begin{array}{l}\text { Aberdeen, Blackfoot, Craters of } \\
\text { the Moon, Idaho Falls, Minidoka, } \\
\text { Rexburg, Roberts }\end{array}$ & $\begin{array}{l}\text { Arco, Atomic City, Howe, } \\
\text { Monteview, Mud Lake, Reno Ranch }\end{array}$ & None \\
\hline
\end{tabular}




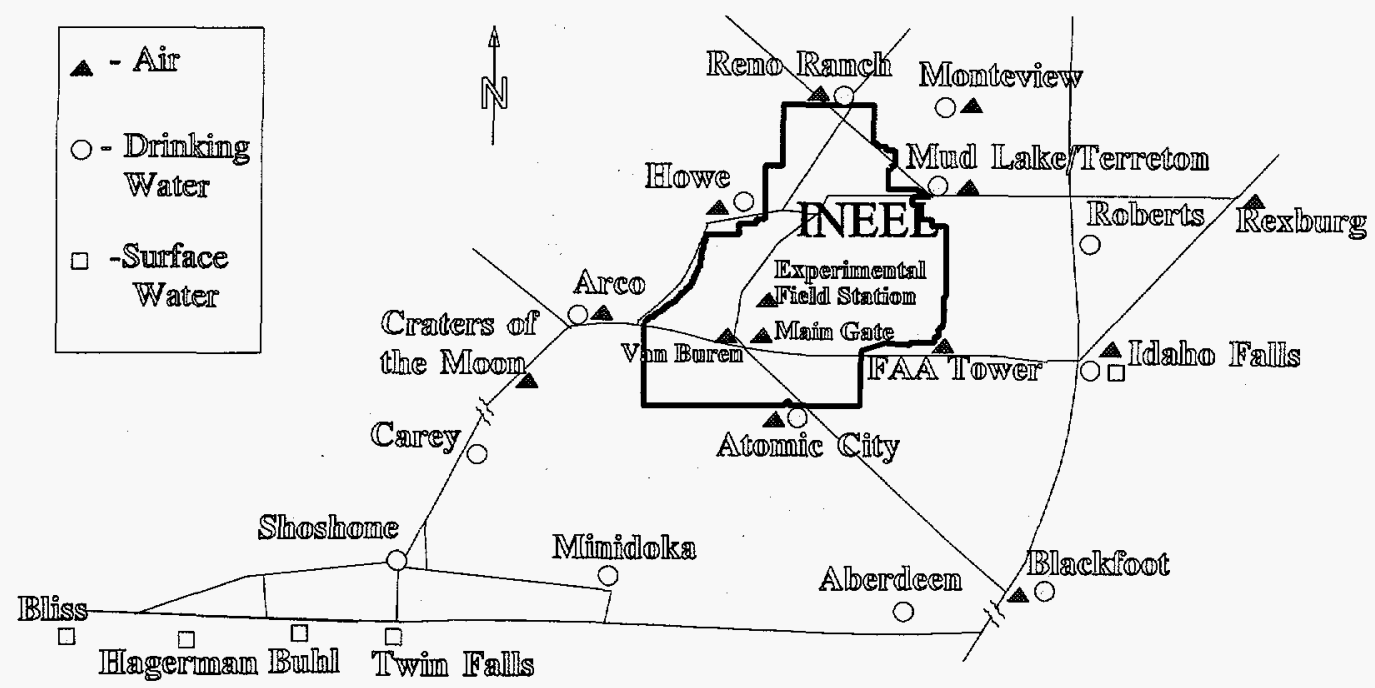

Fig. 1. Air, drinking water, and surface water sampling locations for the INEEL Offsite Environmental Surveillance Program.

also analyzed for ${ }^{90} \mathrm{Sr}$ and transuranic radionuclides ( $\mathrm{Pu}$ and $\mathrm{Am})$. To monitor for tritium in the air, atmospheric moisture was collected at two offsite locations, with a third station added in October at the Madison Middle School Community Monitoring Station in Rexburg. Precipitation was collected at three locations (two onsite and one offsite) to further assess levels of tritium.

The Foundation funded the Interagency Monitoring of Protected Visual Environments (IMPROVE) samplers located at Craters of the Moon National Monument and the INEEL, which are operated under a Memorandum of Understanding between the DOE and the National Park Service. The Foundation also operated the IMPROVE sampler located at the INEEL, and sent semiweekly samples to the University of California, Davis for analysis. The IMPROVE program is used nationwide at national parks and wilderness areas to measure parameters that can reduce visibility.

As part of the Environmental Protection
Agency (EPA) Environmental Radiation Ambient Monitoring System program, the Foundation collected biweekly air filters from a high-volume air sampler in Idaho Falls. These samples were sent to the EPA laboratory in Montgomery, Alabama for analysis. Monthly precipitation and quarterly drinking water samples were also collected for the program.

The Foundation obtained semiannual water samples from 11 drinking-water locations and two surface-water locations. In addition, quarterly samples were collected at two drinking-water and three surface-water sites in the Magic Valley. All samples were analyzed for gross alpha, gross beta, and tritium.

We collected milk from one dairy weekly and from eight other dairies monthly. Each milk sample was analyzed for ${ }^{131} \mathrm{I}$, with one sample from each location also analyzed for tritium and ${ }^{90} \mathrm{Sr}$ during the year. During 1996 , the Environmental Surveillance Program initiated sampling for ${ }^{129} \mathrm{I}$, a long-lived radionuclide that has been a major contributor 


\begin{tabular}{|c|}
\hline $\begin{array}{l}\text { - Milk } \\
\text { - Lettuce } \\
\text { - Wheat } \\
\text { - Potatoes } \\
\text { - Soil } \\
\text { - Dosimeter }\end{array}$ \\
\hline
\end{tabular}

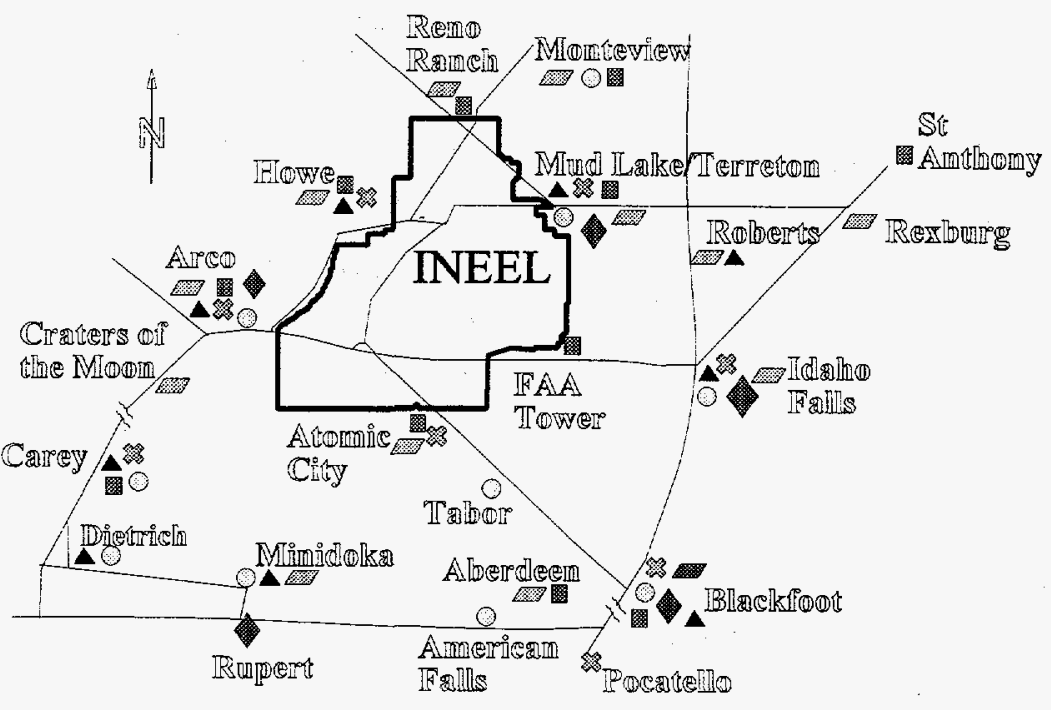

Fig. 2. Soil and foodstuff sampling locations for the INEEL Offsite Environmental Surveillance Program.

to the projected dose to residents near the INEEL during the last few years. These analyses, which use extremely sensitive accelerator mass spectrometry, are being performed by Isotrace Laboratory at the University of Toronto.

Annual samples of foodstuffs were collected from private gardens (lettuce), local grain elevators (wheat), and warehouses (potatoes) (Fig. 2). These were analyzed for gamma-emitting radionuclides and ${ }^{90} \mathrm{Sr}$. The Foundation took muscle, liver, and thyroid samples from sheep that grazed onsite and at a control location, and from game animals killed on INEEL roads. Fish were collected from the Big Lost River on the INEEL.

Environmental dosimeters were collected from 13 sites during May and November to assess radiation exposure at distant and boundary sites (Fig. 2). Radiation exposure was also measured at the Madison and Mountain View Middle School Community Monitoring Stations using pressurized ion chambers beginning in October.

\section{Analytical Laboratories}

For the radiological monitoring program, the Foundation obtained analytical services from three independent laboratories. The Environmental Monitoring Laboratory at Idaho State University performed most routine analyses, including gross alpha, gross beta, tritium, and most gamma spectrometry. In July of 1996, this laboratory, which had previously also conducted work for the State Oversight Program, was divided into two entirely separate operations. Foundation work during the latter half of the year was performed by the newly created Environmental Assessment Laboratory at Idaho State University. Strontium-90, transuranic analyses, and some gamma spectrometry analyses were obtained from Quanterra, Inc. in Richland, Washington. As described earlier, ${ }^{129}$ I analyses were conducted by Isotrace Laboratory at the University of Toronto. 
Crocker Nuclear Laboratory at the University of California, Davis, continued to provide analytical support for the IMPROVE program. Environmental dosimetry was provided by the Operational Dosimetry Unit of Lockheed-Martin Idaho Technologies Company.

\section{Quality Assurance Program}

The Foundation continued to implement, and completed revision of, a set of over 40 standard operating procedures for sample collection and preparation, safety, and quality assurance incorporated into the controlled Environmental Science and Research Foundation Manual. Five new procedures were prepared for the manual in 1996.

We strove to continue improving the performance of environmental surveillance program activities. Routine assessments were continued on sample collection and preparation. These assessments ranged from informal "walkdowns" of selected field activities by the program manager to formal surveillances using a checklist by a designated quality assurance coordinator. The quality assurance coordinator is independent of the surveillance program, reporting directly to the Executive Director. In addition to field assessments, the coordinator also prepares quarterly reports of quality assurance data, and assists with evaluations of laboratory performance. Training and qualification for staff members continued to be upgraded.

A program to obtain and submit blind spiked samples (samples containing a known amount of radioactive material) to laboratories performing radiological analyses was also continued. This program, combined with routine analysis of sample blanks, replicate samples, and split samples assists in providing verification of the ability of our contracted laboratories to accurately perform given analyses. In 1996, approximately $13 \%$ of samples submitted for analysis were quality control samples.

\section{Sample/Data Management System}

The Foundation installed and began use of the new Sample and Environmental Analyses Management System (SEAMS) during 1996. This system allows surveillance program users to schedule samples on a variety of sampling intervals and generate sampling plans and bar-code labels for sampling events. These samples are then tracked using the system-generated identification number through the analysis process until disposal. Analytical data received from the laboratories in electronic format can be loaded directly into the system.

\section{Public Information}

One of the Foundation's major goals is to inform and educate the public about environmental surveillance at the INEEL. We used a variety of approaches to provide information on the environmental surveillance program to the general public including presentations, an educational display, media releases, articles in the Foundation Focus newsletter, and reports. Detailed information on these is provided in Section II of this document.

\section{Community Monitoring Program}

A major component of the public education program included the development of Community Monitoring Stations to inform stakeholders about, and involve them in, environmental surveillance at the INEEL. Installation of air sampling, radiation measurement and meteorological equipment was completed for the two Community Monitoring Stations located at Madison Middle School in Rexburg and Mountain View Middle School in Blackfoot. Training of the station mangers, who are science teachers in the respective schools, was completed during the year. A station manager manual consisting of standard operating 
procedures for operating the equipment and interpreting data generated by the stations was prepared for use by the teachers. At each station, a public display area allows for the presentation of data on current weather conditions and gamma radiation levels. More importantly, the stations serve as an educational tool for the two schools. Data generated by the stations is accessed through the school's computer systems, allowing this data to be incorporated into science classes dealing with topics such as meteorology and radioactivity.

\section{PRODUCTS}

The Foundation prepared the INEEL Site Environmental Report for Calendar Year 1995 as required by DOE Orders (Mitchell et al. 1996a). The report contained environmental monitoring data collected by the Foundation, INEEL contractors, the U.S. Geological Survey, and the National Oceanic and Atmospheric Administration. In addition, the report summarized the INEEL's compliance status with respect to major environmental laws and regulations, and provided a summary of significant environmental restoration and waste management issues. The report also included an evaluation of the hypothetical dose to a member of the public resulting from operations at the INEEL. Following DOE-ID and INEEL contractor review, the report was printed and distributed to more than 400 individuals. The Foundation will also prepare the INEEL Site Environmental Report for 1996.

We also completed a summary document (Roush et al. 1996) as a companion report to the Annual Site Environmental Report. This report highlighted the significant data and conclusions from the Annual Site Environmental Report, and was written so the public could easily understand the results and interpretations of environmental programs at the INEEL.
The Foundation prepared quarterly environmental surveillance reports for 1995 and the first quarter of 1996 (Mitchell et al. 1996b. Peterson et al. 1996, Peterson et al. 1996a, 1996b, 1996c, 1996d). Following review by DOE-ID, each of these reports was printed and distributed. A draft report was prepared for the second quarter of 1996.

\section{LITERATURE CITED}

Mitchell, R. G., D. Peterson, and D. L. Hoff. 1996a. Idahı National Engineering Laboratory site environmental report for calendar year 1995. ESRF-014, DOE/ID12082(95). Environmental Science and Research Foundation, Idaho Falls, ID. 203 pp.

Mitchell, R. G., D. Peterson, and D. Roush. 1996b. INEEL offsite environmental surveillance program report for the fourth quarter of 1995. ESRF-011(4QT95). Environmental Science and Research Foundation, Idaho Falls, ID. 33 pp.

Peterson, D., R. G. Mitchell, and A. Adams. 1996. INEEL offsite environmental surveillance program report for the first quarter of 1995. ESRF-011(1QT95). Environmental Science and Research Foundation, Idaho Falls, ID. 25 pp.

Peterson, D., R. G. Mitchell, and D. Roush. 1996a. INEEL offsite environmental surveillance program report for the second quarter of 1995. ESRF-011(2QT95). Environmental Science and Research Foundation, Idaho Falls, ID. 30 pp.

Peterson, D., R. G. Mitchell, and D. Roush. 1996b. INEEL offsite environmental surveillance program report for the third quarter of 1995. ESRF-011(3QT95). Environmental Science and Research Foundation, Idaho Falls, ID. 28 pp. 
Peterson, D., R. G. Mitchell, and D. Roush. 1996d. INEEL offsite environmental surveillance program report for the first quarter of 1996. ESRF-011(1QT96). Environmental Science and Research Foundation, Idaho Falls, ID. 25 pp.
Roush, D., R. G. Mitchell, and D. Peterson. In summary: Idaho National Engineering Laboratory site environmental report for calendar year 1995. ESRF-015.

Environmental Science and Research Foundation, Idaho Falls, ID. 26 pp. 


\title{
SECTION II
}

\section{ENVIRONMENTAL EDUCATION}

\begin{abstract}
Through its educational mission, the Foundation aims to improve public understanding of the environment of the Idaho National Engineering and Environmental Laboratory (INEEL). This is accomplished using four program objectives and seven communications strategies. During calendar year 1996, the Foundation issued 25 news releases to a mailing list of 212 media outlets. During 1996, Foundation staff and University Affiliates gave 49 presentations to more than 1,500 persons and exhibited displays and posters at 21 locations. The Foundation published 10 reports. A Foundation-operated travelers' information radio station broadcast continuously during 1996 and was available to approximately 800,000 vehicles. A total of 14 , three- to five-minute repeating messages were aired. Awards were presented to 16 area high school students for new radio messages. A new educational tactic, implemented in 1996, is a pair of community monitoring stations, at Rexburg and Blackfoot. The stations provide community involvement and educational opportunities, as well as actual environmental surveillance data. Information from the stations are being incorporated into science and mathematics curricula at Rexburg's Madison Middle School and Blackfoot's Mountain View Middle School. Foundation Focus, an information-filled newsletter about the INEEL's environment, reached an expanded audience in 1996. Circulation, consisting of selected individuals, requestors, and libraries, grew to 1,024 at the end of 1996.
\end{abstract}

Keywords: Education, communications, community monitoring stations, Foundation Focus newsletter, news releases, traveler's information radio.

\section{JUSTIFICATION}

Through its educational mission, the Foundation aims to improve public understanding of the environment of the Idaho National Engineering and Environmental Laboratory (INEEL). This goal requires regular, planned, two-way exchange of information about ecological research, environmental monitoring, and environmental issues. Results from the Foundation's environmental surveillance program and findings from Foundation research projects are a major source of information for these educational activities.

Much is known about the state of the environment at the INEEL, but this knowledge is not widely understood. So, there exist tremendous opportunities for learning. The Foundation's environmental education program attempts to reach a variety of audiences with information packaged in a variety of ways. Environmental education programs are characterized by three elements (Disinger and Monroe 1994):

"an acknowledgment of the world as an integrated ecological and social system; a recognition of humans and their creations as part of the environment, and; emphasis on human values, attitudes, and perceptions in shaping environmental issues and their solutions."

The Foundation's education program strives to include each of these elements in its public communications.

In this post-Cold War era, powerful perceptions of the U.S. Department of Energy (DOE) as the nation's nuclear weapons maker continue to overshadow DOE's important role as a major natural resource agency.

Regionally, the INEEL offers a paradox to people in Idaho. It is a place where a high-quality remnant of the region's native sagebrush steppe is juxtaposed with restricted access, nuclear reactors and radioactive materials storage. A successful environmental education program at the INEEL necessarily incorporates a recognition of its environmental legacy of radioactive materials, which must be properly managed, with plenty of information about the wealth of Idaho's natural heritage present on the Site. Understanding both of these interpretations of the INEEL's environment is necessary for wise management decisions. The perceptions and opinions of elected officials, activists, 
adjacent landowners, tribal leaders, INEEL employees, other Idaho residents, and visitors to the upper Snake River Valley impact DOE's management of the INEEL environment. An aggressive and steady environmental public education program at the INEEL increases awareness, fosters understanding, and results in better decisions.

\section{Program Objectives}

The Foundation's Environmental Education Program objectives are:

- Develop and distribute attractive and factual materials about the environment of the INEEL.

- Disseminate results from the INEEL Offsite Environmental Surveillance Program and provide opportunities for public involvement.

- Provide environmental education activities to schools.

- Distribute information about INEEL ecological research findings to publics beyond traditional scientific audiences.

These objectives contribute directly to better public understanding of the INEEL.

\section{Communication Strategies}

The Foundation designed and employed seven communication strategies in 1996. These strategies were to:

- Periodically release information about INEEL ecological research and environmental surveillance to news media outlets in Idaho and other Rocky Mountain states.

- Make presentations to a wide variety of audiences, including elementary and secondary schoolchildren, civic groups, university students and faculty, INEEL tour groups, and professional peers.

- Place interpretive signs, posters, and displays, some portable and some permanent, at various locations.

- Publish brochures, reports, flyers, papers, and other documents, many of which were designed and written for non-technical audiences.

- Broadcast messages about the natural and cultural history of the INEEL, as well as results and findings from the Foundation's surveillance and research programs, via a travelers' information radio station.

- Work with the INEEL Offsite Environmental Surveillance Program to operate two community monitoring stations and to foster public involvement in the surveillance program.

- Publish a widely-distributed newsletter, Foundation Focus.

Decisions affecting environmental quality need to be made with the best available knowledge and thorough scientific understanding. The Foundation's environmental education program seeks to help provide information that contributes to wise decision-making. Through vigorous, timely, and fair communications, the program's ultimate goal is to provide people with the best information available about the INEEL's environment.

\section{PROGRAM ACCOMPLISHMENTS}

\section{News Releases}

The Foundation issued 25 news releases. Most of these releases were distributed to a mailing list of 212 media outlets, including 
Idaho newspapers, periodicals, and broadcast stations, as well as some major outlets in neighboring states. From January to December, and every month in between, the Foundation's activities at the INEEL were mentioned by news media across Idaho, with additional instances of coverage in Montana, South Dakota, and Utah. Most coverage can be traced to planned releases of information. Response across the media shows success in obtaining both print and broadcast attention. Communicating to broad audiences is necessary for public understanding of the Foundation's scientific work.

\section{Presentations}

A skilled personal presentation to an attentive audience is accepted as one of the best ways to explain scientific findings. For this reason, Foundation scientists often give presentations at scientific meetings. Multimedia presentations are also used to provide information to other types of audiences. During 1996, the Foundation staff and university affiliates gave 49 presentations to professional peers, students, civic leaders, and other audiences (Table 2, Table 3). More than 1,500 persons attended Foundation presentations during the year.

\section{Interpretive Signs, Posters, and Displays}

In order to reveal the purposes and findings of INEEL ecological research and environmental monitoring, the Foundation creates and places illustrative media--signs, displays, and posters (Table 3 ).

As part of the community monitoring stations, established at Madison Middle School in Rexburg, ID, and Mountain View Middle School in Blackfoot, ID, permanent displays were constructed. At each CMS, signs explaining the basis for environmental monitoring, explaining INEEL Offsite Environmental Surveillance Program findings, and featuring real-time display of data were installed. These signs also contain a bulletin board where stations managers display messages and student work. Other interpretive signs identifying and explaining each piece of instrumentation within the CMS enclosures were installed onto the fences surrounding each station.

Another permanent interpretive sign, at the Protective Cap/Biobarrier Experiment site at the Experimental Field Station on the INEEL, explains the experiment to visitors in a concise and attractive manner. It is used by tour groups visiting the field experiment, and is stocked with handouts and brochures.

The Foundation made a portable display describing the INEEL Offsite Environmental Surveillance Program available to libraries and other public institutions throughout Idaho. It appeared at 11 locations: Hailey, Twin Falls, Rupert, Fort Hall, Pocatello, Arco, Carey, Terreton, Boise, Rexburg, and Rigby. The display shows the extent of the INEEL's offsite surveillance program, interprets recent results, and explains basic radiation science. Information handouts and surveillance program reports were available at the display. Foundation scientists created five peer-reviewed posters for presentation at scientific meetings.

\section{Publications}

Research findings become accepted by the scientific community after peer scrutiny and publication. During 1996, 10 reports were published by the Foundation (Table 4). In addition to Foundation published reports, Foundation researchers had 20 technical, peer-reviewed articles and reports published, in-press, or submitted during 1996 (Appendix A). 
Table 2. Foundation Presentations During 1996.

Title

Environmental Monitoring by the Foundation

Board of Directors, Yellowstone Soil
Conservation District, St. Anthony, ID

Ecological Research and Environmental

Monitoring at the INEL

Geology Students from Ricks College, Rexburg, ID

Ecological and Radioecological Research and

Environmental Monitoring at the INEL

INEL Offsite Environmental Surveillance

Program

Environmental Tour of the INEL

Dose to Humans from Game Animals

Environmental Research and Ecological Risk Assessment at the INEL

Health Physics Summer Practicum graduate students from Colorado State University and Idaho State University

Idaho Falls Chamber of Commerce

Summer 1996 Associated Western University students of LMITCO

Radiological Environmental Monitoring Class at Idaho State University

Representatives of EPA Region 10 and LMITCO Waste Area Group managers

Being an Environmental Scientist

Students at Clair E. Gale Junior High School, Idaho Falls

Natural History and Environmental Research of the INEL

Training for Community Monitoring Station

Managers

Training for Community Monitoring Station

Managers

Protective Cap/Biobarrier Experiment

Protective Cap/Biobarrier Experiment

Faculty Members from Ricks College, Rexburg, ID

Teachers at Madison Middle School, Rexburg, ID

Teachers at Mountain View Middle School, Blackfoot, ID

Environmental Studies Students from Ricks College, Rexburg, ID

Forest Ecologist from Commonwealth Scientific and Industrial Research Organization of New South Wales, Australia

Sensitive, Threatened and Endangered Species at the INEL

Decontamination and Decommissioning Program Managers, LMITCO

Recovery of the 1994 Butte City and 1995 Argonne Burns

Science Action Teams and Teacher Research Assistant Program participants and mentors

Recovery of the 1994 Butte City and 1995 Argonne Burns 
Table 2 (continued). Foundation Presentations During 1996.

\begin{tabular}{l} 
Title \\
\hline Protective Cap/Biobarrier Experiment \\
Natural Resources of the INEL \\
Conducting Ecological Research and \\
Environmental Surveillance in Southeastern \\
Idaho \\
Diversity of Natural Resources at the INEL \\
Protective Cap/Biobarrier Experiment
\end{tabular}

Benefits from and to the Science Action Team Assessing Recovery of the Butte City Fire

Protective Cap/Biobarrier Experiment

Protective Cap/Biobarrier Experiment

Animals of the Sagebrush Steppe

Protective Cap/Biobarrier Experiment and Other Environmental Research at the INEL

Environmental Surveillance, Wildfire

Recovery, and Ecological Research

Ecological Research and Environmental Monitoring at the INEL

Communicating about the Idaho National Engineering Laboratory's Environment

Working as a Journalist and Environmental Educator at a DOE Site

Environmental Science and Research Foundation and Some Advice for Your Environmental Career

Students from Associated Western Universities and the Upward Bound and National Science Foundation internship programs at Idaho State University

Craters of the Moon National Monument staff

Researchers and administrators at the Instituto de Ecologia in Xalapa, Veracruz, Mexico

Potential trustees of the INEL Natural Resource Damage Assessment committee

LMITCO consultants on final closure of the Subsurface Disposal Area

INEL Institute Program Meeting on Science Action Teams as an Idaho School to Work Model

EPA Region 10 risk assessment staff

Biology students from Ricks College, Rexburg, ID

Fourth Grade Classes at Hillview Elementary School, Ammon, ID

INEL Employee and Guest Tour

Representatives from Office of Emergency Management and Office of Energy Intelligence, DOE-HQ, and LMITCO

INEL Employee and Guest Tour

Ecopsychology: The Interconnectedness of Humans and the Environment, College of Social Sciences and Public Affairs, Boise State University, ID

English Classes at Clair E. Gale Junior High School, Idaho Falls, ID

Environmental Legal Assistant, Paralegal, and Legal Secretary Program Students, Eastern Idaho Technical College, Idaho Falls, ID 
Table 2 (continued). Foundation Presentations During 1996.

Title

Audience

Environmental Surveillance and Research by Idaho Falls Chamber of Commerce the Foundation

Animals of the Sagebrush Steppe

Fourth Grade Classes at Midway Elementary

School, Menan, ID

Job Shadowing with an Environmental

Ninth Grade Student from Clair E. Gale Junior Technician

Waterfowl Use of Wastewater Ponds at the Idaho National Engineering Laboratory

High School, Idaho Falls, ID

Conference on Ecosystem Restoration and Creation, Tampa, FL

Bird Communities at Wastewater Ponds in Southeastern Idaho

Conference on Ecosystem Restoration and Creation, Tampa, FL

Raptors of the Intermountain and Prairie Regions

South Dakota Agricultural Heritage Museum, Brookings

Wildlife Research in a High Desert-the INEL South Dakota State University, Brookings

Bird Studies in a Desert Shrub Ecosystem, Idaho

South Dakota Ornithologist Union Annual Meeting, Brookings

Modeling the Location of Snake Dens on the Idaho National Engineering Laboratory

American Fisheries Society Meetings, Logan, UT

Modeling the Location of Snake Dens

Idaho Herpetological Society Meetings, Boise

The Irrepressible Reptiles of Idaho

Science Trek, Idaho Museum of Natural History, Pocatello

Natural History of Snakes in Bannock County

Hawthorne Junior High Field Trip to Cherry

Springs, Pocatello, ID

Snake Safety on the Idaho National

Fleet Management, INEEL

Engineering Laboratory

Snake Safety on the Idaho National Engineering Laboratory

Snake Safety on the Idaho National Engineering Laboratory

Snake Safety on the Idaho National Engineering Laboratory

Snake Safety on the Idaho National Engineering Laboratory

Status of small owl species on the Idaho National Engineering Laboratory

CFA Medical Staff, INEEL

Fleet Management (additional personnel), INEEL

CFA Fire Crew, INEEL

TAN Fire Crew, INEEL

Graduate Seminar, Department of Wildlife and Fisheries, South Dakota State University, Brookings 
Table 3. Foundation Signs, Posters, and Displays During 1996.

\begin{tabular}{|c|c|}
\hline Title & Audience \\
\hline $\begin{array}{l}\text { Research Parks and NEPA: Two Decades of } \\
\text { Symbiosis }\end{array}$ & $\begin{array}{l}\text { Earth Day Celebration, Ricks College, } \\
\text { Rexburg, ID }\end{array}$ \\
\hline $\begin{array}{l}\text { DOE's National Environmental Research } \\
\text { Parks }\end{array}$ & $\begin{array}{l}\text { North American Association for } \\
\text { Environmental Education Annual } \\
\text { Conference, Burlingame, CA }\end{array}$ \\
\hline $\begin{array}{l}\text { INEL Offsite Environmental Surveillance } \\
\text { Display }\end{array}$ & Hailey (ID) Library \\
\hline $\begin{array}{l}\text { INEL Offsite Environmental Surveillance } \\
\text { Display }\end{array}$ & Twin Falls (ID) Public Library \\
\hline $\begin{array}{l}\text { INEL Offsite Environmental Surveillance } \\
\text { Display }\end{array}$ & Demary Memorial Library, Rupert, ID \\
\hline $\begin{array}{l}\text { INEL Offsite Environmental Surveillance } \\
\text { Display }\end{array}$ & Tribal Business Center, Fort Hall, ID \\
\hline $\begin{array}{l}\text { INEL Offsite Environmental Surveillance } \\
\text { Display }\end{array}$ & Marshall Public Library, Pocatello, ID \\
\hline $\begin{array}{l}\text { INEL Offsite Environmental Surveillance } \\
\text { Display }\end{array}$ & Lost River Community Library, Arco, ID \\
\hline $\begin{array}{l}\text { INEL Offsite Environmental Surveillance } \\
\text { Display }\end{array}$ & Little Wood River Library, Carey, ID \\
\hline $\begin{array}{l}\text { INEL Offsite Environmental Surveillance } \\
\text { Display }\end{array}$ & Heart of the Valley Library, Terreton, ID \\
\hline $\begin{array}{l}\text { INEL Offsite Environmental Surveillance } \\
\text { Display }\end{array}$ & Boise (ID) Public Library \\
\hline $\begin{array}{l}\text { INEL Offsite Environmental Surveillance } \\
\text { Display }\end{array}$ & Madison Public Library, Rexburg, ID \\
\hline $\begin{array}{l}\text { INEL Offsite Environmental Surveillance } \\
\text { Display }\end{array}$ & Rigby (ID) Public Library \\
\hline $\begin{array}{l}\text { Root Growth and Water Relations of Bromus } \\
\text { tectorum in Response to Drying Soil Surfaces }\end{array}$ & $\begin{array}{l}\text { Ecological Society of America Annual } \\
\text { Meeting, Providence, RI }\end{array}$ \\
\hline $\begin{array}{l}\text { Habitat and Behavior Assessment of an } \\
\text { Endemic Rabbit Species (Brachylagus } \\
\text { idahoensis) in Southeastern Idaho }\end{array}$ & $\begin{array}{l}\text { Society for Conservation Biology and } \\
\text { Ecological Society of America Joint Annual } \\
\text { Meetings, Providence, RI }\end{array}$ \\
\hline $\begin{array}{l}\text { Heavy Metals in Small Mammal Habitats and } \\
\text { Populations at the Idaho National } \\
\text { Engineering Laboratory }\end{array}$ & $\begin{array}{l}\text { American Society of Mammalogists National } \\
\text { Meeting, Grand Forks, ND }\end{array}$ \\
\hline $\begin{array}{l}\text { Avoidance of Lead Contaminated Food } \\
\text { Sources by Peromyscus maniculatus }\end{array}$ & $\begin{array}{l}\text { American Society of Mammalogists National } \\
\text { Meeting, Grand Forks, ND }\end{array}$ \\
\hline
\end{tabular}


Table 3 (continued). Foundation Signs, Posters, and Displays During 1996.

\begin{tabular}{|c|c|}
\hline Title & Audience \\
\hline $\begin{array}{l}\text { Post-fire Succession and Exotic Invasion in } \\
\text { Sagebrush-grass steppe of Southeastern Idaho }\end{array}$ & $\begin{array}{l}\text { Undergraduate Biological Research } \\
\text { Conference, Pacific University, Forest Grove, } \\
\text { OR }\end{array}$ \\
\hline $\begin{array}{l}\text { Madison Middle School Community } \\
\text { Monitoring Station }\end{array}$ & $\begin{array}{l}\text { Community Monitoring Station visitors, } \\
\text { Madison Middle School, Rexburg, ID }\end{array}$ \\
\hline $\begin{array}{l}\text { Mountain View Middle School Community } \\
\text { Monitoring Station }\end{array}$ & $\begin{array}{l}\text { Community Monitoring Station visitors, } \\
\text { Mountain View Middle School, Blackfoot, } \\
\text { ID }\end{array}$ \\
\hline $\begin{array}{l}\text { The Protective Cap/Biobarrier Experiment: } \\
\text { Assessing Natural Materials and Ecological } \\
\text { Processes to Isolate Hazardous Wastes }\end{array}$ & $\begin{array}{l}\text { Protective Cap/Biobarrier Experiment } \\
\text { visitors, Experimental Field Station, INEEL }\end{array}$ \\
\hline
\end{tabular}

\section{Travelers' Information Radio}

A Foundation-operated traveler's information radio station broadcast continuously during 1996 . Located at the intersection of U.S. Highways 20 and 26, the low-powered transmitter broadcasts on a frequency of $530 \mathrm{AM}$ and is available to persons in the 800,000 vehicles driving on these highways each year. Three- to five-minute repeating messages discuss the environment, natural history, and cultural history of the INEEL and the southeastern Idaho desert. A total of 14 messages were aired. Signs three miles from the junction alert travelers to tune in. To provide future messages as well as an educational opportunity for students, a contest was held for area high school students. Awards were presented to 16 students.

Community Monitoring Stations and Public Involvement in the INEEL Offsite Environmental Surveillance Program

The INEEL Offsite Environmental Surveillance Program, operated by the Foundation, extensively monitors the southeastern Idaho environment for INEEL contamination. In 1996, it collected more than 2,378 samples on which more than 3,653 analyses were performed. The program provides ample assurances of INEEL operational safety. Public awareness of the program's results is integral to allaying fears, correcting misconceptions, and promoting support for the INEEL. But, making the INEEL environmental surveillance data available to anyone who asks for them is not enough. The Foundation packages the data, along with easy-to-follow interpretations and explanations of their underlying concepts, into reports, report summaries, fact sheets, multimedia presentations, and a portable display.

A new educational tactic, implemented in 1996 , is a pair of community monitoring stations, at Rexburg and Blackfoot. These stations monitor radioactivity and particulates in the air, environmental radiation levels, and weather conditions, providing real-time measurements and collecting samples for laboratory analysis. The stations provide community involvement and educational opportunities, as well as actual environmental surveillance data. Information from the stations are being incorporated into science and mathematics curricula at Madison Middle School and Mountain View Middle School. 
Table 4. Foundation Reports Published During 1996.

\begin{tabular}{|c|c|c|}
\hline Report Number & Report Name & Author(s) \\
\hline ESRF-005 & $\begin{array}{l}\text { Plant Communities, Ethnoecology, and Flora } \\
\text { of the Idaho National Engineering Laboratory }\end{array}$ & $\begin{array}{l}\text { Jay E. Anderson, } \\
\text { Kristin T. Ruppel, } \\
\text { James M. Glennon, } \\
\text { Karl E. Holte, and } \\
\text { Ronald C. Rope }\end{array}$ \\
\hline $\begin{array}{l}\text { ESRF-011 } \\
\text { (1QT95) }\end{array}$ & $\begin{array}{l}\text { INEL Offsite Environmental Surveillance } \\
\text { Program Report for the First Quarter of } 1995\end{array}$ & $\begin{array}{l}\text { Don Peterson, Russell } \\
\text { Mitchell, Amy Adams }\end{array}$ \\
\hline $\begin{array}{l}\text { ESRF- } \\
011(2 \mathrm{QT} 95)\end{array}$ & $\begin{array}{l}\text { INEL Offsite Environmental Surveillance } \\
\text { Program Report for the Second Quarter of } \\
1995\end{array}$ & $\begin{array}{l}\text { Don Peterson, Russell } \\
\text { Mitchell, Donny Roush }\end{array}$ \\
\hline $\begin{array}{l}\text { ESRF- } \\
011(3 Q T 95)\end{array}$ & $\begin{array}{l}\text { INEL Offsite Environmental Surveillance } \\
\text { Program Report for the Third Quarter of } 1995\end{array}$ & $\begin{array}{l}\text { Don Peterson, Russell } \\
\text { Mitchell, Donny Roush }\end{array}$ \\
\hline $\begin{array}{l}\text { ESRF- } \\
011(4 Q T 95)\end{array}$ & $\begin{array}{l}\text { INEL Offsite Environmental Surveillance } \\
\text { Program Report for the Fourth Quarter of } \\
1995\end{array}$ & $\begin{array}{l}\text { Don Peterson, Russell } \\
\text { Mitchell, Donny Roush }\end{array}$ \\
\hline ESRF-012 & $\begin{array}{l}\text { Environmental Science and Research } \\
\text { Foundation Annual Technical Report to DOE- } \\
\text { ID, Calendar Year } 1995\end{array}$ & $\begin{array}{l}\text { Timothy D. Reynolds } \\
\text { and Randall C. Morris } \\
\text { (eds) }\end{array}$ \\
\hline ESRF-013 & $\begin{array}{l}\text { Methods for monitoring bat population trends } \\
\text { at lava-tube caves on the Idaho National } \\
\text { Engineering Laboratory }\end{array}$ & Bosworth, W.R. III \\
\hline $\begin{array}{l}\text { ESRF-014 and } \\
\text { DOE/ID- } \\
12082(95)\end{array}$ & $\begin{array}{l}\text { Idaho National Engineering Laboratory Site } \\
\text { Environmental Report for Calendar Year } 1995\end{array}$ & $\begin{array}{l}\text { Russell G. Mitchell, } \\
\text { Don Peterson, Diana L. } \\
\text { Hoff }\end{array}$ \\
\hline ESRF-015 & $\begin{array}{l}\text { In Summary: Idaho National Engineering } \\
\text { Laboratory Site Environmental Report for } \\
\text { Calendar Year } 1995\end{array}$ & $\begin{array}{l}\text { Donny Roush, Russell } \\
\text { G. Mitchell, Don } \\
\text { Peterson }\end{array}$ \\
\hline $\begin{array}{l}\text { ESRF- } \\
\text { 016(1QT96) }\end{array}$ & $\begin{array}{l}\text { INEL Offsite Environmental Surveillance } \\
\text { Program Report: First Quarter of } 1996\end{array}$ & $\begin{array}{l}\text { Don Peterson, Russell } \\
\text { Mitchell, Donny Roush }\end{array}$ \\
\hline
\end{tabular}

\section{Foundation Focus}

Foundation Focus, an information-filled newsletter covering Foundation surveillance and research activities as well as natural and cultural history of the INEEL, reached an expanded audience in 1996. Circulation, consisting of selected individuals, requestors, and libraries, grew by more than 55 percent to 1,024 at the end of 1996 . Issues typically opens with "From the Desk of the Director." The piece provides an opportunity to recap surveillance and research accomplishments and express plans for future activities. The 
balance of each newsletter presents a cross section of research findings, monitoring results, and educational opportunities. The final issue of this volume was significant in introducing an in-depth series of articles entitled, "The Site, the Plain, the Aquifer, and the Magic Valley." The newsletter's value as a direct voice of an independent non-profit organization is significant in highlighting important environmental work at the INEEL.

\section{PRODUCTS}

The products of the Foundation's environmental education program include all the news releases, presentations, displays, Foundation reports, Traveler's Information Radio messages, and the Foundation Focus.

\section{LITERATURE CITED}

Disinger, J. F. and Monroe, M. C. 1994.

Defining environmental education.

National Consortium for Environmental Education and Training, School of Natural Resources, University of Michigan, Ann Arbor. $40 \mathrm{pp}$. 


\title{
SECTION III
}

\section{ENVIRONMENTAL SERVICES AND SUPPORT}

\begin{abstract}
A principal element of the mission of the Environmental Science and Research Foundation is to provide the Department of Energy, Idaho Operations Office (DOE-ID) with a variety of environmental services and support. In 1996, the Foundation performed 37 National Environmental Policy Act (NEPA) field evaluations and conducted environmental surveys to provide information for NEPA documentation, Risk Assessments, and other activities. We conducted follow-on field surveys to monitor the success of several revegetation efforts. We authored the Ecological Resources section of the Environmental Assessment for a new silt/clay borrow source at the Idaho National Engineering and Environmental Laboratory (INEEL). The Foundation assisted DOE-ID in discussions with the Idaho Department of Fish and Game (IDF\&G), the U.S. Fish and Wildlife Service (USF\&WS), the Bureau of Land Management, and other natural resource management agencies. We performed wildlife surveys and provided data on elk and pronghom populations to DOE-ID and IDF\&G. Information on Threatened and Endangered Species was obtained from the USF\&WS and interpreted for the INEEL. The Foundation continued to serve as a resource for ecological expertise for the INEEL. Technical staff served on committees dealing with a variety of ecological, radioecological, ecological risk, and natural resource issues such as wildland fire, soil capillarity, grazing and occurrence of sensitive species at each Waste Area Group on the INEEL. We served on the NEPA Planning Board and the Natural Resource Damage Assessment Trustees Committee, and also served on one INEEL committee unrelated to ecological resources, but concerning ecological researchers: the emergency notification committee. We responded to more than 250 inquiries regarding environmental or surveillance issues from INEEL personnel, the scientific community, stakeholders and the general public.
\end{abstract}

Keywords: Big game, elk, environmental assessment, Idaho Department of Fish and Game, National Environmental Research Park, natural resources, NEPA, pronghorn, raptors, sensitive species, Threatened and Endangered species, U.S. Fish and Wildlife Service, wildlife surveys.

\section{JUSTIFICATION}

Ecological and natural resource related information is vital not only for the completion of environmental compliance documentation (e.g. Environmental Checklists, Environmental Assessments and Environmental Impact Statements) but is important for the day-to-day management at the INEEL. For example, knowing the habits of rattlesnakes and the location of den sites can improve worker safety. Foundation staff members have more than 85 years collective experience collecting and interpreting ecological and environmental information at the INEEL. This knowledge resource is a valuable to the entire INEEL family. The Foundation makes this information available to DOE-ID, Lockheed Martin Idaho Technologies Company (LMITCO), subcontractors, INEEL stakeholders and the general public. Responding to requests for information and expertise is a growing segment of the Foundation's activities. Valuable as it is, past experience is insufficient to assure competent decision making. Past experience with the ecological resources of the site must be supplemented with current knowledge about the constantly changing plant and animal populations on the INEEL. For this reason the Foundation regularly conducts plant and wildlife surveys and interprets the results of these surveys for INEEL decision makers.

The Foundation's role in performing and interpreting plant and animal surveys complements its role in transferring information to the public, state and federal agencies, and legislators. Being aware of the current condition of the populations of plants and animals enables us to respond quickly and accurately to public concerns about environmental issues involving the INEEL. For example, past wildlife depredation on the agricultural areas surrounding the INEEL prompted criticism of DOE by IDF\&G and local legislators. Knowledge of the current status and trends in the populations of elk and pronghorn helps the Foundation anticipate depredation problems work with IDF\&G and 
DOE to proactively address depredation issues and explore reasonable resolutions. The quality of the environment on and near the INEEL is important to most local residents because it is one of the last large, undisturbed areas of sagebrush steppe remaining in the western United States, and is an important habitat for game and nongame animals. The scientific community also recognizes the inherent ecological benefits of such a large tract of protected and relatively undisturbed habitat. For example, in 1996 at the request of Idaho Partner's in Flight the Foundation nominated the INEEL for designation as a national Important Bird Area.

\section{Program Objectives}

The Foundation's specific environmental services and support objectives are to:

- Respond to requests from DOE-ID, other DOE sites, other State and Federal agencies, and members of the public for assistance, advice, and information on a wide range of ecological issues, including wildlife and environmental surveillance.

INEEL managers as well as resource managers at other DOE facilities, or with other State and Federal Agencies, often require information about the INEEL environment to effectively manage the resources in their care. The Foundation is the primary repository of such information. In addition, responding promptly and accurately to these requests is an important part of the INEEL initiative to be open and honest about environmental issues. Because the environmental picture at the INEEL is generally positive, this also provides positive public relations for DOE.

- Conduct field investigations and offer ecological recommendations for the NEPA process.
Most Environmental Checklists require biological evaluations and many require field investigations. The Foundation performs these evaluations and investigations. The Foundation also provides current information about the plant and animal species inhabiting the INEEL, including threatened, endangered, or other species of special concern, for use in Environmental Assessments and Environmental Impact Statements.

- Coordinate and participate in studies to determine the status of Threatened and Endangered, or otherwise important species on the INEEL.

There is one Endangered Species (gray wolf), two Threatened Species (bald eagle and Ute's ladies tresses), and 16 species of concern that may occur on, or be impacted by, the INEEL. Monitoring these species is necessary to ensure DOE-ID is able to meet its legal obligations with regard to the Endangered Species Act. Monitoring these species and their habitats also simplifies and expedites NEPA field evaluations for activities at the INEEL. In addition, depredating species (pronghorn and elk) and other game species (sage grouse and mule deer) are of interest to the local public and other State and Federal agencies. Elk and pronghorn have caused hundreds of thousands of dollars of damage to crops in agricultural lands adjacent to the INEEL in the past decade. Monitoring these species provides information with which to develop management strategies for animals that use the INEEL for part or all of the year. It also allows DOE to have informed dialog with game management agencies and stakeholder groups.

Breeding Bird Surveys have proven to be an effective method of monitoring ecological and environmental change. For this reason, the Foundation continues to conduct annual Breeding Bird Surveys. For more information on this effort, see the research report titled 
"Breeding Bird Surveys on the INEEL" in Section V of this report.

Similarly, birds of prey are at the top of the food chain and are important indicators of ecological and environmental change. For this reason, the Foundation participates in the annual midwinter eagle count sponsored by the Biological Resources Division of the U.S. Geological Survey (USGS). On the INEEL, the Foundation expands this count to include all raptors. This count enables us to track population trends and to compare trends on the INEEL with those in similar locations. These data help the biological evaluation of construction and other activities on the INEEL to prevent further decreases in sensitive species. Two raptors (ferruginous hawk and burrowing owl) inhabiting the INEEL are former C2 candidates for listing as threatened or endangered under the Endangered Species Act. We periodically monitor nesting success of these species.

- Serve as a point of contact for environmental expertise and information exchange with the USDA Forest Service, USDA Animal and Plant Health Inspection Service (Animal Damage Control [ADC]), USDA Dubois Sheep Experiment Station, USGS Biological Resources Division Raptor Research Center, USDI Bureau of Land Management (BLM), USDI National Park Service, USDI Fish and Wildlife Service and the Idaho Department of Fish and Game in matters involving natural resource management.

Sharing information with these agencies is important for enhancing and maintaining DOE's credibility with them. The Foundation has specific responsibilities with respect to some of these agencies. For example, as part of the DOE Memorandum of Understanding with BLM that established the grazing zones on the INEEL, DOE agreed to fund predator control by ADC in the grazing areas. The Foundation funded and administered that program for DOE in 1996. During some years the INEEL is winter range for one third of all the pronghorn in Idaho and hundreds of elk. Besides being game species, these animals have a history of depredation on the agricultural fields surrounding the site. The IDF\&G is responsible for managing this depredation problem. Because these animals spend time on the INEEL, an area closed to hunting, IDF\&G looks to DOE-ID for assistance. The Foundation contributes to the dialogue between DOE and IDF\&G on this and other issues. For example, the Foundation provides current information about animal population trends to IDF\&G and has assisted in the coordination of elk removal operations.

- Correspond with USF\&WS to satisfy the requirements of Section 7 of the Endangered Species Act and exercise local authority to determine whether proposed developments on the INEEL require formal Biological Assessment consultation with that agency.

Compliance with the Endangered Species act requires DOE-ID to semiannually ask the USF\&WS for an updated list of threatened and endangered species likely to occur on the INEEL. The Foundation makes this request on behalf of DOE-ID. Moreover, the Foundation advises DOE-ID when it is appropriate to enter into a formal Section 7 Consultation with the USF\&WS.

- Coordinate and encourage use of the Idaho National Environmental Research Park by ecologists, environmental scientists, and other natural resource scientists.

The boundaries of the INEEL enclose a large expanse of undeveloped and relatively undisturbed sagebrush steppe habitat. This unique environment provides an excellent opportunity for environmental scientists and ecologists to study natural processes and, in 
particular, the impact of human energy development on such systems. For this reason, DOE designated the INEEL as a National Environmental Research Park in 1975. As coordinator of the Research Park, the Foundation encourages scientists to perform research on the INEEL, coordinates their work, and assists them with logistics. DOE-ID obtains valuable data about the INEEL environment from the studies performed by these scientists. In addition, by supporting this research DOE demonstrates its concern for the environment to the public. Finally, because much of the research is conducted by students seeking graduate degrees, DOE demonstrates its support for science education.

- Review and contribute to documents describing the ecology and radioecology of the INEEL whether generated at the INEEL, by other DOE sites, or by outside agencies.

Foundation staff are recognized as experts on the ecology and environment of the INEEL as well as in individual speciality disciplines. We review manuscripts for technical accuracy and often author the ecological sections of various INEEL documents.

\section{PROGRAM ACCOMPLISHMENTS}

Following is a brief summary of the variety and scope of the environmental services and support provided by the Foundation staff. During the calendar year of 1996, the Foundation:

- Responded to more than 250 requests for information about our environmental surveillance and research programs, or the environmental contamination, radioecology, and ecology of the INEEL.

These requests came from DOE-ID, its contractors, interest groups, the scientific community, and the general public.

Responses to these requests included short, informal telephone conversations, preparation of written documents (Appendix A) and formal presentations (Appendix B).

- Conducted 37 field evaluations in support of NEPA at the INEEL (Table 5). The Foundation has taken a leading role in monitoring compliance with requirements of Environmental Checklists during the progress of projects at the INEEL.

- Conducted follow-on field surveys to monitor the success of revegetation efforts at the TAN sewage lagoon, Spreading Area B, Pad A, and the Foundation Travelers' Radio tower, and developed and presented the INEEL position to the Idaho Department of Environmental Quality regarding the need for additional revegetation efforts at $\mathrm{Pad} \mathrm{A}$.

- Corresponded with the USF\&WS to satisfy the requirements of Section 7 of the Endangered Species Act. The list of listed and proposed endangered and threatened species and species of concern (Table 6) was distributed to the DOE-ID NEPA Compliance Officer, LMITCO NEPA Environmental Affairs, several INEEL subcontractors and various individuals. A letter was developed and distributed to describe changes in the classification system and the addition of some species.

- Coordinated the annual national mid-winter eagle count sponsored by the USGS Biological Resources Division Raptor Research Field Station.

The zone covered the INEEL and all of Butte and Clark Counties. Several staff members participated in this count. For the INEEL, this was an expanded effort to count 
Table 5. NEPA Field Evaluations conducted by the Environmental Science \& Research Foundation during 1996.

\begin{tabular}{|c|c|c|c|}
\hline Date & Contractor & NEPA Number & Project \\
\hline $1-3$ & DOE & INEEL-ID-91017 & $\begin{array}{l}\text { NEPA requirements for controlled hunt on the } \\
\text { INEEL }\end{array}$ \\
\hline $1-15$ & LMITCO & INEEL-96-008 & $\begin{array}{l}\text { Road rehabilitation throughout INEEL (Notified } \\
\text { on 5-20-96 that project will not begin until } 1998 \text {. } \\
\text { We will be asked to perform additional } \\
\text { evaluations at that time.) }\end{array}$ \\
\hline $2-15$ & LMITCO & INEEL-96-003 & Drilling test wells at Spreading Area B \\
\hline $3-4$ & LMITCO & CPP-96-002 & Installation of new boiler feed pipe near CPP 606 \\
\hline $3-6$ & LMITCO & & Closure of the Waste calcining Facility \\
\hline $3-27$ & LMITCO & INEEL-96-007 & $\begin{array}{l}\text { Removal of underground storage tanks at CFA and } \\
\text { PBF }\end{array}$ \\
\hline $4-1$ & LMITCO & CFA-96-003 & Drilling test holes for CFA gravel pit expansion \\
\hline $4-1$ & LMITCO & RWMC-96-001 & RWMC Pit 9 crane laydown area \\
\hline $4-11$ & ESRF & CFA-96-001 & $\begin{array}{l}\text { Impacts of irrigation of native vegetation on the } \\
\text { INEEL }\end{array}$ \\
\hline $4-29$ & LMITCO & CFA-96-004 & $\begin{array}{l}\text { Disassembly and disposal of CFA communications } \\
\text { tower }\end{array}$ \\
\hline $5-9$ & LMITCO & CFA-96-005 & $\begin{array}{l}\text { CFA borrow source for Landfills I, II, and III } \\
\text { CERCLA action (evaluation amended 5-16-96) }\end{array}$ \\
\hline $5-16$ & LMITCO & CFA-96-005 & $\begin{array}{l}\text { Revision of evaluation dated 5-9-96 for CFA } \\
\text { borrow source for Landfills I, II, and III CERCLA } \\
\text { action }\end{array}$ \\
\hline $5-16$ & ANL-W & INEEL-96-012 & $\begin{array}{l}\text { Reseeding of Argonne Burn Area with spring } \\
\text { wheat }\end{array}$ \\
\hline $5-16$ & ESRF & INEEL-96-013 & $\begin{array}{l}\text { Uptake parameters of contaminant species } \\
\text { important to INEEL ecological risk assessment } \\
\text { research project }\end{array}$ \\
\hline $5-23$ & LMITCO & INEEL-96-011 & Operable Unit $10-03$ ordnance assessment \\
\hline $5-23$ & LMITCO & CPP-96-009 & CPP-spent nuclear fuel dry storage project \\
\hline $5-23$ & LMITCO & CFA-96-0XX & CFA trailer relocation to support HPIL operations \\
\hline
\end{tabular}


Table 5 (continued). NEPA Field Evaluations conducted by the Environmental Science \& Research Foundation during 1996.

\begin{tabular}{|c|c|c|c|}
\hline Date & Contractor & NEPA Number & Project \\
\hline $6-10$ & LMITCO & & $\begin{array}{l}\text { Revegetation plan for the BORAX-V } \\
\text { decontamination and decommissioning site }\end{array}$ \\
\hline $6-11$ & LMITCO & CFA-96-007 & CFA laydown area for landfill cap activity \\
\hline $7-3$ & LMITCO & TAN-96-010 & $\begin{array}{l}\text { Drilling monitoring and extraction wells at TAN } \\
\text { (evaluation amended 8-14-96) }\end{array}$ \\
\hline $7-15$ & LMITCO & CFA-96-016 & INEEL landfill complex modifications \\
\hline $7-15$ & LMITCO & INEEL-96-019 & $\begin{array}{l}\text { INEEL NOAA Remote Optical Sensor test } \\
\text { program }\end{array}$ \\
\hline $7-18$ & LMITCO & RWMC-96-006 & RWMC Animal Control \\
\hline $7-30$ & LMITCO & TAN-96-011 & TAN hanger gate temporary parking lot \\
\hline \multirow[t]{2}{*}{$8-14$} & LMITCO & INEEL-96-020 & Demolition of ARVFS bunker \\
\hline & LMITCO & & $\begin{array}{l}\text { Environmental issues related to closure of CFA } 754 \\
\text { tank farm }\end{array}$ \\
\hline $8-24$ & LMITCO & CFA-96-010 & $\begin{array}{l}\text { Removal of contaminated soil at five locations at } \\
\text { CFA }\end{array}$ \\
\hline $8-14$ & LMITCO & TAN-96-010 & Drilling monitoring and extraction wells at TAN \\
\hline $8-15$ & LMITCO & PBF-96-002 & Removal of mixed waste at ARA \\
\hline $8-22$ & ANL-W & & $\begin{array}{l}\text { Ecological evaluation of ANL-W dust control } \\
\text { activities }\end{array}$ \\
\hline $8-23$ & LMITCO & INEEL-96-021 & Operable Unit 10-03 Ordnance removal Action \\
\hline $9-11$ & LMITCO & & $\begin{array}{l}\text { Request for comments on update of Environmental } \\
\text { Checklists }\end{array}$ \\
\hline $9-17$ & ESRF & INEEL-96-026 & Study of Principal Lineament Origin \\
\hline $9-26$ & ANL-W & ANL EC & $\begin{array}{l}\text { Dust suppression and revegetation of burned desert } \\
\text { areas in the vicinity of ANL-W }\end{array}$ \\
\hline $9-26$ & LMITCO & RWMC-96-009 & RWMC firebreak creation and mitigation \\
\hline $12-4$ & LMITCO & INEEL-96-027 & $\begin{array}{l}\text { Installation of Seismic Velocity Logging Wells for } \\
\text { the } 1997 \text { Seismic Hazards Investigation. }\end{array}$ \\
\hline $12-10$ & DOE & & $\begin{array}{l}\text { Semiannual update of list of Threatened and } \\
\text { Endangered species on the INEEL }\end{array}$ \\
\hline
\end{tabular}


Table 6. Listed Threatened and Endangered Species and Other Species of Concern Possibly Occupying the INEEL (from USF\&WS, December, 1996).

\begin{tabular}{|c|c|c|}
\hline Species & Classification & Occurrence on the INEEL \\
\hline $\begin{array}{l}\text { Bald Eagle (Haliaeetus } \\
\text { leucocephalus) }\end{array}$ & Listed: Threatened & Winter Visitor most years \\
\hline Gray wolf (Canis Lupus) & $\begin{array}{l}\text { Listed: Endangered, } \\
\text { Experimental } \\
\text { Population }\end{array}$ & $\begin{array}{l}\text { Several unconfirmed sightings on the } \\
\text { INEEL since } 1993 \text {. }\end{array}$ \\
\hline $\begin{array}{l}\text { Ute's Ladies tresses } \\
\text { (Spiranthes diluvialis) }\end{array}$ & Listed: Threatened & Unknown on the INEEL \\
\hline $\begin{array}{l}\text { Long-eared Myotis } \\
\text { (Myotis evotis) }\end{array}$ & Former C2 species & Limited distribution on INEEL \\
\hline $\begin{array}{l}\text { Small-footed Myotis } \\
\text { (Myotis subulatus) }\end{array}$ & Former C2 species & $\begin{array}{l}\text { Relatively common over much of } \\
\text { INEEL }\end{array}$ \\
\hline $\begin{array}{l}\text { Townsend's big-eared bat } \\
\text { (Corynorhinus } \\
\text { townsendii) }\end{array}$ & Former C2 species & Year round resident on INEEL \\
\hline $\begin{array}{l}\text { Pygmy Rabbit } \\
\text { (Brachylagus idahoensis) }\end{array}$ & Former $\mathrm{C} 2$ species & Limited distribution on INEEL \\
\hline $\begin{array}{l}\text { Merriam's shrew (Sorex } \\
\text { merriami) }\end{array}$ & State protected species & Limited distribution on INEEL \\
\hline $\begin{array}{l}\text { Ferruginous hawk (Buteo } \\
\text { regalis) }\end{array}$ & Former $\mathrm{C} 2$ species & $\begin{array}{l}\text { Summer resident; widespread } \\
\text { distribution on INEEL }\end{array}$ \\
\hline $\begin{array}{l}\text { Long-billed curlew } \\
\text { (Numenius americanus) }\end{array}$ & Former C2 species & $\begin{array}{l}\text { Summer resident; limited distribution } \\
\text { on INEEL }\end{array}$ \\
\hline $\begin{array}{l}\text { Northern Sagebrush } \\
\text { Lizard (Sceloporous } \\
\text { graciosus) }\end{array}$ & Former $\mathrm{C} 2$ species & Widespread distribution on INEEL \\
\hline $\begin{array}{l}\text { Painted milkvetch } \\
\text { (Astragalus ceramicus var } \\
\text { apus) }\end{array}$ & Former C2 species & $\begin{array}{l}\text { Common in sandy areas dominated } \\
\text { by sagebrush on the north end of the } \\
\text { INEEL }\end{array}$ \\
\hline $\begin{array}{l}\text { King's bladderpod } \\
\text { (Lesquerella kingii var } \\
\text { cobrensis) }\end{array}$ & $\begin{array}{l}\text { Idaho Native Plant } \\
\text { Society monitor list }\end{array}$ & Uncommon on East Butte \\
\hline $\begin{array}{l}\text { Nipple cactus } \\
\text { (Coryphantha } \\
\text { missouriensis) }\end{array}$ & $\begin{array}{l}\text { Idaho Native Plant } \\
\text { Society monitor list }\end{array}$ & Uncommon on Reno Point \\
\hline $\begin{array}{l}\text { Sepal-tooth dodder } \\
\text { (Cuscuta denticulata) }\end{array}$ & $\begin{array}{l}\text { Idaho Native Plant } \\
\text { Society Category } 1\end{array}$ & Not known from INEEL \\
\hline $\begin{array}{l}\text { Lemhi milkvetch } \\
\text { (Astragalus aquilonius) }\end{array}$ & $\begin{array}{l}\text { Idaho Native Plant } \\
\text { Society Sensitive } \\
\text { Species }\end{array}$ & $\begin{array}{l}\text { Limited to western foothills on } \\
\text { INEEL }\end{array}$ \\
\hline
\end{tabular}


Table 6 (continued). Listed Threatened and Endangered Species and Other Species of Concern Possibly Occupying the INEEL (from USF\&WS, December, 1996)

\begin{tabular}{lll}
\hline Species & Classification & Occurrence on the INEEL \\
\hline $\begin{array}{l}\text { Winged-seed evening } \\
\text { primrose (Camissonia }\end{array}$ & $\begin{array}{l}\text { Idaho Native Plant } \\
\text { pterosperma) }\end{array}$ & Rare in northwest foothills on INEEL \\
Species & \\
$\begin{array}{l}\text { Spreading gilia } \\
\text { (Ipomopsis }[\doteq \text { Gilia }]\end{array}$ & Idaho Native Plant & Limited to western foothills on \\
polycladon) & Society Category 2 & INEEL \\
$\begin{array}{l}\text { Tree-like oxytheca } \\
\text { (Oxytheca dendroidea) })\end{array}$ & $\begin{array}{l}\text { Idaho Native Plant } \\
\text { Society Sensitive }\end{array}$ & $\begin{array}{l}\text { Uncommon; wide spread in sandy } \\
\text { Specils on INEEL }\end{array}$ \\
\hline
\end{tabular}

not only eagles, but all raptors.

- Conducted two big game surveys (midwinter and midsummer) and supplied the resulting data to DOE-ID and the IDF\&G.

- Participated in INEEL meetings including several established group meetings [e.g., Ecological Risk Assessment Working Group, Natural Resource Damage Assessment Trustees meetings, NEPA Planning Board], ad hoc committees (e.g., Wildland Fire Lessons Learned, Wildland Fire Management, Spreading Area B in situ Soil Characteristics, Emergency Notification of Personnel, CFA Landfill 1, 2 , and 3 Closure) and singular meetings (e.g. Response to BLM request for a short-term increase in grazing on the INEEL). We were instrumental in preventing the development of an unplanned borrow source and the unnecessary destruction of 100 or more acres of mature sagebrush habitat during the CFA Landfill 1, 2 and 3 capping process.

- Provided funding to ADC to conduct predator control on the INEEL. During 1996, 18 lambs were killed by predators on the INEEL. In response to complaints by livestock operators, 64 coyotes were taken by ADC personnel.

- Facilitated the use of the Idaho National Environmental Research Park by 29 scientists from 12 universities. These research efforts supported 13 research assistants, 55 technicians, 9 administrative staff members, 34 temporary employees and volunteers, and science education for 22 graduate students. A total of 162 university personnel participated in Foundation programs on the INEEL. The activities of these research scientists, their students, and their staff are described in Section V of this document.

- Provided technical review of various INEEL documents and management plans (e.g. Idaho National Engineering Laboratory Management Plan for Cultural Resources FINAL DRAFT (DOE/ID-10361, Rev. 1), and authored the sections related to ecology of the Draft Environmental Assessment -- New Silt/Clay Borrow Source for the Idaho National Engineering Laboratory (DOE/EA-1083, October 1996). Foundation Ecologists were referees for eight manuscripts submitted to technical 
journals.

- Represented INEEL perspectives at three "by invitation only" working sessions sponsored by DOE-HQ: (1) Improving the qualitative evaluation of environmental impacts at the DOE environmental management sites, (2) Implementing data quality objectives in the ecological risk assessment process, and (3) Long-term performance of in situ stabilization).

- Continued to be active in professional societies (e.g. Northwest Scientific Association, Health Physics Society, Ecological Society of America, American Society of Mammalogists, and others). One member took a seat on the combined executive board and working group of the Idaho Society for Energy and Environmental Education Advocates.

\section{IMPORTANT RESULTS}

The mid-winter raptor survey and the two big game surveys provided results important for understanding the potential impacts of NEEL activities on wildlife species of concern.

The results of the mid-winter raptor survey are reported in Table 7 . No bald eagles were observed within the INEEL boundary. As usual, the most common raptor observed on the site during the survey was the rough-legged hawk. Numbers of these birds were less than half of the 13 year average. Due to natural year-to-year variability in populations and wintering conditions, changes in numbers of raptors observed were not considered significant when compared to the long-term averages.

The midwinter big game survey was conducted February 12-14, 1996. Using a standard line-transect techniques, we observed 221 elk and estimated a population of 945 pronghorn. The number of elk observed in the winter of 1996 was nearly double of that in 1995 . This was primarily due to a new herd of over 100 elk wintering on the west side of the INEEL. Fewer pronghorn were recorded on the INEEL than during previous winters. Most likely because of the lack of snow cover and relatively mild conditions in the valleys adjacent to the INEEL, few pronghorn migrated beyond the mouth of the valleys.

The midsummer survey was conducted on August 12 and 13, 1996. Using a quadrat count technique, we estimated pronghorn and elk populations at 1,247 and 201 individuals, respectively. Summer pronghorn numbers were much higher than the previous two summer counts, partially due to a rebounding population and to a counting technique that is known to yield slightly higher estimates. The highest summer pronghorn densities (14.8 pronghorn per square mile) were observed in areas adjacent to agriculture. The number of elk estimated to be on the site during the summer of 1996 appeared to be much higher than the previous summer count. This was likely an artifact resulting from changes in our sampling technique. In 1995 we reported the actual number of elk observed during complete aerial survey of the INEEL. In 1996 we only surveyed randomly selected portions of the INEEL, and estimated a INEEL population number by extrapolation from those data. 
Table 7. Number of birds of prey observed on the INEEL during the 1996 winter raptor survey.

\begin{tabular}{lcc} 
Species & 1996 tally & 13-year average \\
\hline Bald eagle & 0 & 1.8 \\
Golden eagle & 9 & 10.1 \\
Prairie falcon & 3 & 1.8 \\
Peregrine falcon & 1 & 0.1 \\
Merlin & 1 & 0.1 \\
American kestrel & 3 & 0.7 \\
Rough-legged hawk & 28 & 63.8 \\
Red-tailed hawk & 0 & 0.7 \\
Ferruginous hawk & 0 & 0.3 \\
Swainson's hawk & 0 & 0.1 \\
Northern harrier & 2 & 0.8 \\
Great-horned owl & 0 & 0.6 \\
Short-eared owl & 0 & 1.8 \\
Common raven & 21 & 17.0 \\
Northern shrike & 3 & 2.1 \\
\hline
\end{tabular}




\title{
SECTION IV
}

\section{RISK ASSESSMENT}

\begin{abstract}
Foundation staff members have participated in the ecological risk assessment guidance development effort at the Idaho National Engineering and Environmental Laboratory (INEEL) from the beginning. During 1996, one Foundation Research Scientist was a member of the team that led the planning for the site-wide ecological risk assessment at the INEEL. The Foundation was actively involved in developing a Field Sampling Plan for the site-wide ecological risk assessment through planning meetings and document reviews. That effort continues in 1997 . We contributed to the development of DOE complex-wide ecological risk assessment strategies and guidance by participation on two national working groups. We also shared the INEEL's ecological risk assessment expertise with the ecological risk assessment community through reviews of documents from other national laboratories, and guidance documents from EPA and DOE. The Foundation continued to provide human health and ecological risk assessments and assessment advice to DOE, LMITCO, and the other members of the INEEL family as needed.
\end{abstract}

Keywords: CERCLA, CRESP, data quality objectives, DOE-HQ, ecological risk assessment, sensitive species, waste area groups.

\section{JUSTIFICATION}

The Environmental Protection Agency (EPA), under the Comprehensive Environmental Response, Compensation, and Liability Act (CERCLA) requires that all Superfund sites perform both human health and ecological risk assessments. In addition, the Action Plan for Implementing the Federal Facility Agreement and Consent Order (FFA/CO) for the INEEL requires developing risk assessment guidance for the entire INEEL site.

Human health risk assessment is a welldeveloped discipline and these assessments are conducted using existing guidance from the EPA. However, ecological risk assessment is not well developed, particularly for primarily terrestrial ecosystems like the INEEL. In this case, guidance is not available and must be developed specifically for the site. The tremendous variety of contaminants, pathways, and species of potential concern across the INEEL makes this a particularly difficult and time-consuming task. It requires knowledge of the contaminant distribution on the site, its ecology and radioecology, and expertise in risk assessment methodology.

The Foundation has participated in the development of guidance for ecological risk assessment from the beginning of this effort at the INEEL. As coordinators of the National
Environmental Research Park and the primary organization for the study of the ecology and radioecology of the INEEL, we have unique expertise that is critical to the success of the guidance development effort. In 1996 we participated in planning the Site-wide (WAG 10) ecological risk assessment, including developing portions of the draft Field Sampling Plan.

Successful ecological risk assessment cannot occur in a vacuum. It is important to coordinate our efforts at the INEEL with those of other sites to benefit from one another's experience. Thus, participation in working groups dealing with ecological risk assessment problems across the DOE complex is essential for establishing a successful ecological risk assessment program. Foundation staff members participated, by invitation, in two such groups in 1996 and were active in reviewing documents from other sites and regulatory agencies.

\section{Objectives}

Program objectives for 1996 were to:

- Participate, with the INEEL Ecological Risk Assessment Group, in developing techniques for conducting a site-wide ecological risk assessment at the INEEL. 
- Contribute to the development of DOE complex-wide ecological risk assessment strategies and guidance by participation on national working groups.

- Share the INEEL's ecological risk assessment expertise with the ecological risk assessment community through reviews of documents from other National Laboratories, guidance documents from EPA and DOE.

- Provide human health and ecological risk assessments and assessment advice to DOE as needed.

\section{PROGRAM ACCOMPLISHMENTS}

The Foundation had accomplishments related to all objectives during 1996. Specifically, we:

- Contributed to the development of techniques for conducting site-wide and WAG-wide ecological risk assessments.

One Foundation staff member, several Lockheed Martin Idaho Technologies Company (LMITCO) employees, and representatives from consulting firms interacted regularly with one another and with personnel from the EPA, the State of Idaho, and DOE-ID to develop and refine methodologies for conducting this assessment. Specifically, the Foundation helped develop models of radiation dose to animals via ingestion of surface water and made comparisons of the currently used estimation algorithm for external dose with an exact calculation. On two occasions, we provided tours of the INEEL emphasizing sensitive environments and species for consultants participating in ecological risk assessments.

- Participated in developing the Field Sampling Plan for the Site-wide Ecological

\section{Risk Assessment.}

We familiarized the consultant writing the plan with the INEEL environment by providing a tour of the area emphasizing the sensitive environments. In addition, we met regularly with the consultant and the LMITCO team to discuss the elements of the plan. We reviewed drafts of the plan as it progressed. The plan is currently under revision.

At LMITCO's request, the Foundation began developing a scientifically defensible, biometrical sampling plan that, if implemented, would have provided conclusive evidence about impacts to biota from CERCLA chemicals.

- Provided logistical support for two LMITCO summer interns to summarize the Foundation's reprint database with respect to it's relevance to ecological risk. Their report is in progress.

- Participated in a DOE-HQ sponsored working group to develop methodologies for incorporating the Data Quality Objectives process into the Ecological Risk Assessment process. We reviewed drafts of the product from that workshop but it has not yet been published as a final document.

- Interacted regularly by telephone and E-mail with other people involved in ecological risk assessment across the nation to discuss ideas and share solutions to ecological risk problems which are of interest across the DOE complex.

In this context, the Foundation was called upon to review EPA's proposed guidelines for ecological risk assessment and provide comments for inclusion in a DOE-HQ response. We also reviewed a white paper from Sandia National Laboratory describing a ecological risk screening process for radionuclides. As result of that review, 
Sandia decided to implement the screening process already developed by the Foundation in cooperation with LMITCO. On two separate occasions, we advised the State of New Mexico on methodologies being used to conduct ecological risk assessments at the INEEL. We took advantage of all these opportunities to learn more about how assessments are being conducted in other areas.

- Provided input to LMITCO on the thinking behind the proposed rule 10 CFR 834 , Subpart F.

Because of the Foundation's participation in the development of the rule as it relates to terrestrial organisms, our input was sought as background for LMITCO's comments on the rule.

In addition to these DOE-ID funded activities, the Foundation engaged in other activities related to ecological risk assessment on the INEEL.

- We participated, by invitation, in a DOE-
HQ sponsored "Working Meeting on improving the qualitative evaluation of environmental impacts at the DOE Environmental Management sites."

This meeting focused on developing a set of questions that could be asked of managers at the Sites that would elicit information appropriate for funding projects based on ecological risk. Our participation in this group was funded by the Consortium for Risk Evaluation with Stakeholder Participation (CRESP).

- We planned and conducted a survey of sensitive species at the INEEL Waste Area Groups.

This effort was supported by LMITCO. Reports from these surveys are currently under revision.

\section{PRODUCTS}

Our effort this year has been primarily advisory in nature and no tangible products have resulted. 


\section{SECTION V}

\section{RESEARCH BENEFITTING THE DOE-ID MISSION}

\section{PROGRAM DESCRIPTION AND SUMMARY}

At the Idaho National Engineering and Environmental Laboratory (INEEL), the Foundation develops scientific goals and conducts environmental research consistent with the needs of the Department of Energy, Idaho Operations Office (DOE-ID). Because the INEEL is a National Environmental Research Park, the Foundation also coordinates ecological research on the INEEL that is not directly supported by funds from DOE-ID. Foundation research supports decision making and regulatory compliance for Waste Management, Environmental Restoration, Spent Nuclear Fuels, and DOEID Infrastructure Programs. DOE-ID uses these data for complying with various mandates and regulations including, but not limited to, the National Environmental Policy Act, the Endangered Species Act, Natural Resource Damage Assessment and Risk Assessment sections of the Comprehensive Environmental Response, Compensation, and Liability Act, and the Federal Noxious Weed Act. Moreover, Foundation research is generally consistent with statements by the Secretary of Energy on land stewardship responsibilities and promotes the mission statement of the National Environmental Research Park.

Some Foundation research projects are INEEL-wide in scope. They are not tied specifically to any particular DOE-ID program, but generally benefit all programs. For example, the pygmy rabbit is classified by the U.S. Fish and Wildlife Service as a species of special concern under the Endangered Species Act. Surveys conducted for this and other species indirectly benefit all site activities and programs by providing the population and distribution information needed to maintain compliance with the
National Environmental Policy Act. Big game surveys (pronghorn, deer, and elk) are also not tied to a particular INEEL program, but provide information that allows DOE-ID to work effectively with stakeholders (e.g. adjacent land owners, sportsmen, legislators, and the Idaho Department of Fish and Game) on issues related to crop depredation and hunting.

Some projects, such as research into the effect of plastic liners on radionuclide cycling and transport in evaporation ponds, are more program specific. Although an individual project may have a single funding source, the research often benefits more than one major INEEL program. Table 8 summarizes which major INEEL programs benefit most from particular research projects.

In 1996, the Foundation conducted research, data analysis, and interpretation on 30 projects. We developed technical publications from three projects for which field work was previously completed. Many individual research projects were related, providing a more comprehensive approach to a particular goal. Projects could be organized into three general categories: (1) contaminant transport, detection, and effects; (2) stewardship of natural resources; and (3) ecology of waste covers. Results from some projects, such as the suite of experiments associated with the Protective Cap/Biobarrier Experiment, can potentially make significant contributions to municipal and industrial landfill practices, including low-level radioactive waste management. These contributions can result in a considerable future cost savings to DOE.

Fundamental to the Foundation's research program is the active participation of universities from Idaho and from other states in the research process. This association is mutually beneficial. Universities provide 
Table 8. DOE-ID Program Beneficiaries of Specific Environmental Science and Research Foundation Research Projects.

\begin{tabular}{l}
$\quad$ Research Project \\
\hline Wildife Use of Man-Made Ponds on the INEEL \\
Breeding and Wintering Populations of Raptors on the INEEL \\
Comparison of Four Protective Cap Designs \\
Mitigating Long-Term Impacts of Small Mammal Burrowing \\
Effectiveness of Ant Biobarriers: Laboratory Studies \\
Effectiveness of Ant Biobarriers: Establishing Colonies on PC/BE \\
Soil Subsidence and Snowmelt Erosion on Waste Disposal Sites \\
Distribution and Abundance of the Pygmy Rabbit, a C2 Species \\
Concentrations of Heavy Metals in Populations of Small Mammals \\
Long-Term Vegetation Dynamics \\
Habitat Use and Movement Patterns of Mule Deer \\
Plutonium Distribution Among Soil Phases at the INEEL \\
Lichens as Biomonitors of Air Pollution \\
Breeding Bird Surveys and Long-term Data Analyses \\
Distribution and Status of Reptiles and Amphibians on the INEEL \\
Monitoring Environmental Contaminants with Honey Bees \\
Diversity of the Ant Fauna over the INEEL \\
Radioactivity Cycling in Plastic Lined Evaporation Ponds \\
Radioecology of ${ }^{129}$ I in the Sagebrush Steppe \\
Surface Water Penetration at the Subsurface Disposal Area \\
Occurrence of Small Owls Species on the INEEL \\
Factors Affecting the Distribution of Soil Lichens on the INEEL \\
Fire Ecology of the INEEL \\
Swallows \\
WWP covers \\
Effects of Wastewater Irrigation on Sagebrush Steppe \\
Noxious Weeds on the INEEL \\
Bats on the INEEL \\
Trace Elements \& Organics in SDA Soils \\
Uptake Parameters Important to INEEL Ecological Risk Assessment \\
\hline DOE Progm
\end{tabular}

${ }^{\prime}$ DOE Program abbreviations: IS = Infrastructure, WM = Waste Management, ER = Environmental Restoration, SF $=$ Spent Fuels.

specialized expertise at a reasonable cost to complement the skills available within the Foundation staff. University faculty and students benefit from educational and research opportunities offered by the
Foundation. Four Foundation staff members and 18 University Affiliates served as Principal Investigators on research projects at the INEEL. University personnel included 53 university researchers, graduate students, and 
research assistants and represented 12 universities. Additional Foundation staff members and university personnel supported other phases of the research. A total of 153 university personnel participated in Foundation research programs during 1996.

The most important product of research is information. For the Foundation that information is generally made available in the form of reports and publications. These provide factual and citable sources of information for various INEEL documents (e.g., the Comprehensive Facilities and Land Use Plan and the Environmental Assessment for New Silt/clay Borrow Source). These products provide the credible, defensible, scientific information base needed to support decision making regarding INEEL operations, land and natural resource stewardship, and many other issues.

Because the process of scientific research is not complete without the scrutiny of other scientists, Foundation researchers are required to publish their findings in peer reviewed science journals. In order for the benefits of Foundation research to reach a broader audience, the Foundation strongly encouraged its researchers to recast the information in non-technical outlets. In 1996, the Foundation produced, submitted, or published 20 technical articles for publication in appropriate scientific journals plus 10 Foundation Technical Reports

Other tangible products of our research program include designs (e.g., low-level waste covers), scientific equipment development, new research techniques, novel data analysis procedures, and creative application of existing technologies in new areas.

A product common to all Foundation research projects, and deserving special recognition, is new scientists with advanced degrees. Generally, one or more graduate students work under the direction of a Principal Investigator on each of the research projects. These students receive training in research principles, field experience, and report writing while conducting research for the Foundation. The research provides substance for a Master's thesis or Ph.D. dissertation and satisfies the research requirements for an advanced degree. Seventeen Master of Science students and three Ph.D. students were supported by their participation in Foundation research.

Following are summaries of the individual research projects detailing the scope, significance, major accomplishments, important results, and products produced during 1996. Some of these projects are in their infancy and their summaries focus on and accomplishments such as locating a suitable study area or installing equipment rather than on product completion. For more mature projects, field work may be complete and products such as technical publications and presentations are highlighted. 


\title{
WILDLIFE USE OF MAN-MADE PONDS ON THE IDAHO NATIONAL ENGINEERING AND ENVIRONMENTAL LABORATORY
}

\author{
Lester D. Flake ${ }^{1}$
}

\begin{abstract}
Two manuscripts were accepted for publication in the Proceedings for the 23rd Annual Conference on Ecosystem Restoration and Creation; two oral presentations were given at this meeting. A third paper on mule deer and pronghorn use of wastewater ponds underwent extensive re-analysis and revision and was submitted to the Great Basin Naturalist.
\end{abstract}

Keywords: Man-made ponds, mule deer, pronghorn, wastewater ponds, wildlife habitat.

\section{JUSTIFICATION}

In a cold desert ecosystem such as the Idaho National Engineering and Environmental Laboratory (INEEL), water may be highly limiting to a number of wildlife species. There is a broad array of vertebrate species associated with wastewater ponds on the INEEL. Species such as the Sora (Porzana carolina) and Eared Grebe (Podiceps nigricollis) appear during the reproductive season on man-made ponds such as the north cell of the Naval Reactor Facility (NRF) and the west pond at Argonne National Laboratory-West (ANL-W). Both species are dependent on wetlands with at least some emergent vegetation, which the NRF and ANL-W ponds provide. These examples demonstrate how ponds increase species richness in the desert ecosystem. Because natural ponds containing water throughout the summer are not commonly found on or near the INEEL, man-made ponds play a major role in increasing and maintaining biodiversity on the INEEL.

Empirical and quantitative data indicate wastewater ponds on the INEEL are an important and, for some species, necessary resource for wildlife (Howe and Flake 1989). However, statistically significant, low level, radionuclide contamination has been recorded in several bird species and mammals associated with radionuclide leaching ponds (Halford and Markham 1978). Although studies of animal movements provide important information on the potential for contaminant movement to off site areas, little is known about wildlife use of ponds and subsequent potential exposure to contaminants.

This information will be useful for DOE's Environmental Risk Assessments. It will also support environmental documentation and policy such as the National Environmental Policy Act and Natural Resource Damage Assessment. Information on pond characteristics in relation to wildlife use can be used to design future ponds on the INEEL to increase or decrease wildlife use.

Between 1991 and 1993, Cieminski (1993) examined and reported wildlife use of ponds on the INEEL. The objectives of that study were to:

- Determine daily and seasonal patterns of pond use by birds and intermediate to large mammals.

- Estimate visitation rates, and where possible, actual numbers of birds and mammals using ponds and identify the functional value of ponds for these species.

- Determine pond characteristics that are associated with use of a pond by a particular bird or mammal species. 
- Provide information for predicting the wildlife potential of new ponds constructed at INEEL based on pond characteristics.

That study indicated that INEEL ponds had greater numbers of individual invertebrates but fewer taxa (groupings of taxonomically similar organisms such as all rotifers or all daphnia) than did natural ponds in other studies. High numbers of invertebrates may have been linked to the lack of fish predators and the high levels of nitrogen and phosphorus, particularly in ponds receiving sewage effluent. The abundance of invertebrates likely influenced bird use. INEEL ponds were used by a minimum of 144 bird species, with peak numbers of species occurring from April through September. Wastewater ponds provided important feeding and resting areas for migrant birds. They also provided watering, feeding, and reproductive sites for many bird species that reproduce on the INEEL. The greatest numbers of bird species were found at large, nutrient rich ponds surrounded by dense grass or shrub cover. Numbers of individuals within a species or species grouping were often influenced by other pond characteristics. For example, shorebirds were attracted to ponds with increased amounts of bare shoreline.

Wastewater ponds also attracted big game species. Mule deer were observed at waste water ponds from June through December. Peak use was during September and October. Pronghorn were most commonly seen at the ponds in July and August although use occurred from May through November. Ponds with more succulent forage on the periphery received the heaviest use by ungulates.

\section{Objectives}

The objectives of this present effort were to:
- Develop and submit manuscripts for publication to appropriate journals, symposia proceedings, or Foundation technical reports, from data previously collected on wildlife use of wastewater ponds on the INEEL.

- Respond to journal reviews with appropriate editing and analysis on accepted papers through final publication stage.

\section{PROJECT ACCOMPLISHMENTS}

Two manuscripts were prepared and submitted for publication in a symposium proceedings; these two manuscripts were accepted for publication in the symposium proceedings. A third manuscript was revised (complete reanalysis of the data) and submitted for journal review. Two oral presentations were given at an international symposium.

\section{RESULTS}

We concluded that many ponds on the INEEL are important to a great variety of bird species and several large mammals. They add to the diversity of wildlife on the INEEL. Compared with natural wetlands, INEEL ponds had fewer invertebrate taxa but more individuals of most taxa.

\section{PRODUCTS}

Three technical publications were prepared in 1996.

- Cieminski, K. L., and L. D. Flake. 1996. Bird communities at wastewater ponds in southeastern Idaho. In Proceedings of the 23rd Annual Conference on Ecosystem Restoration and Creation, Tampa, Florida (in press). 
- Flake, L. D. and K. L. Cieminski. 1996. Waterfowl use of wastewater ponds on the Idaho National Engineering Laboratory. In Proceedings of the 23rd Annual

Conference on Ecosystem Restoration and Creation, Tampa Florida (in press).

- Cieminski, K. L. 1996. Mule deer and pronghorn use of wastewater ponds in a cold desert. Submitted to Great Basin Naturalist.

Two technical presentations were made in 1996.

- Cieminski, K. L. and L. D. Flake. 1996. Bird communities at wastewater ponds in southeastern Idaho. 23rd Annual Conference on Ecosystem Restoration and Creation, May 16-17, Tampa, Florida.

- Flake, L. D. and K. L. Cieminski. 1996.
Waterfowl use of wastewater ponds at the Idaho National Engineering Laboratory. 23rd Annual Conference on Ecosystem Restoration and Creation, May 16-17, Tampa, Florida.

\section{LITERATURE CITED}

Cieminski, K. L. 1993. Wildlife use of wastewater ponds at the Idaho National Engineering Laboratory. Unpublished MS thesis. South Dakota State University, Brookings. $233 \mathrm{pp}$.

Halford, D. K. and O. D. Markham. 1978. Radiation dosimetry of small mammals inhabiting a liquid radioactive waste disposal area. Ecology 59:1047-1054.

Howe, F. P. and L. D. Flake. 1989.

Mourning dove use of man-made ponds in a cold-desert ecosystem in Idaho. Great Basin Naturalist 49:627-631. 


\title{
BREEDING AND WINTERING POPULATIONS OF RAPTORS ON THE IDAHO NATIONAL ENGINEERING AND ENVIRONMENTAL LABORATORY
}

\author{
Lester D. Flake ${ }^{2}$
}

\begin{abstract}
Two popular manuscripts based on previously collected field data were revised and submitted to nontechnical outlets. Additional photographs needed for publication of the popular articles were taken on the INEEL. One popular paper was subsequently published. The other is in review. Additional revision took place on a technical manuscript which will likely be submitted to a professional journal in CY-97. All manuscripts have been reviewed by DOE and the Foundation. Three seminars or talks were presented.
\end{abstract}

Keywords: Birds of prey, indicator species, raptors, sensitive species.

\section{JUSTIFICATION}

The Idaho National Engineering and Environmental Laboratory (INEEL) is designated as a National Environmental Research Park. This provides an excellent field laboratory for monitoring long-term changes in natural populations of wildlife, including birds of prey, and separating natural population variability from impacts of energy related development. Several species of owls, hawks, and eagles occupy the INEEL seasonally. The Bald Eagle (Haliaeetus leucocephalus) is a winter visitor that is classified as a threatened species. The Ferruginous Hawk (Buteo regalis) and Burrowing Owl (Athene cunicularia) nest on the INEEL and are considered species at risk, formerly classified as Candidates (C2) for the Threatened and Endangered Species List.

Birds of prey are considered indicator species, providing a warning to society of unacceptable levels of contaminants in the environment. Their position in the food chain dictates that persistent toxins that accumulate in smaller prey organisms will likely accumulate in raptors as well. Thus, raptors can be important as early indicators of contamination problems. Although previous studies (Craig and Craig 1984) documented that populations of nesting and wintering raptors fluctuate greatly, there is no information indicating a decline in raptor populations on the INEEL.

Monitoring these species is important for the Department of Energy (DOE). This complies with the spirit and intent of the Endangered Species Act and the National Environmental Policy Act, and demonstrates DOE's commitment to land stewardship (U.S. DOE 1994). Further, the evidence of a stable raptor population suggests a healthy ecosystem and provides a strong message to the public of the adequacy of environmental safeguards on the INEEL.

\section{Objectives}

We completed field research on raptors of the INEEL in 1994 (Hansen 1994). The research included a comprehensive assessment of past and present raptor population numbers, and identified the distribution of nest sites, nest site characteristics, nesting and fledging success, and priority nesting areas. We also modernized and updated the existing database. Based on those results, our objectives for 1996 were to:

- Evaluate the status of raptors on the INEEL listed by state or federal agencies as endangered, threatened, or candidate species, or species of special concern.

- Develop and submit manuscripts to 
appropriate technical journals or popular publication.

- Respond to journal reviews with appropriate editing and analyses or reanalyses as necessary to enhance the opportunity for ultimate publication in the scientific literature.

- Develop and present seminars or other talks on raptor research on the INEEL.

\section{PROJECT ACCOMPLISHMENTS}

One popular manuscript was published and a second was submitted. Three oral presentations either specifically on INEEL raptors or on INEEL raptors and other research on the INEEL were presented to various audiences in South Dakota.

\section{PRODUCTS}

- Hansen, R. W. and L. D. Flake. 1996. Prairie biologists in the desert. South Dakota Conservation Digest. Pp. 12-13, 15.

- Hansen, R. W. (In review). Hawks of Idaho's high desert. Idaho Wildlife.
- Flake, L. D. Raptors of the intermountain and prairie regions. Presented at the South Dakota Agricultural Heritage Museum, Brookings. January 1996.

- Flake, L. D. Wildlife research in a high desert--the INEL. Open seminar for faculty and students at South Dakota State University. October 9, 1996.

- Flake, L. D. Bird studies in a desert shrub ecosystem, Idaho. Banquet speaker for South Dakota Ornithologist Union annual meeting. Brookings. October 12, 1996.

\section{LITERATURE CITED}

Craig, T. H. and E. H. Craig. 1984. Recent changes in Buteo abundance in southeastern Idaho. Murrelet 65:91-93.

Hanson, R. W. 1994. Raptor use of the Idaho National Engineering Laboratory. Unpublished MS. thesis. South Dakota State University, Brookings, South Dakota. $141 \mathrm{pp}$.

U. S. Department of Energy. 1994. Stewards of a National Resource. DOE/FM-0002. U.S. Department of Energy, Washington, DC. 


\title{
COMPARISON OF FOUR PROTECTIVE CAP DESIGNS FOR BURIAL OF HAZARDOUS WASTE AT THE IDAHO NATIONAL ENGINEERING AND ENVIRONMENTAL LABORATORY
}

\author{
Jay E. Anderson, Teresa D. Ratzlaff, Eric Duffin, and Micha Miller ${ }^{3}$
}

\begin{abstract}
The Protective Cap/Biobarrier Experiment was designed to rigorously test the performance of four protective cap configurations. The objective is to recommend an economical cap that uses natural ecosystem processes to protect interred hazardous waste from moisture and minimizes long-term maintenance. Cap designs include $2 \mathrm{~m}$ of soil, caps with a gravel-cobble biobarrier at a depth of either $0.5 \mathrm{~m}$ or $1 \mathrm{~m}$ in $2 \mathrm{~m}$ of soil, and an 'EPA cap' with a meter of soil over a plastic liner covering compacted clay. The experiment includes three replications of the four caps, three irrigation treatments, and two vegetation types. Dependent variables include evapotranspiration, soil moisture, plant cover, and plant water status. In spring 1996, the soil wetting front reached $1.2 \mathrm{~m}$ in soil-only plots, to the depth of biobarriers in those plots, and to the plastic liner in the EPA plots. Under $310 \mathrm{~mm}$ of summer irrigation, water percolated to a depth of $1 \mathrm{~m}$ on the soil-only and $1-\mathrm{m}$ biobarrier plots, but did not penetrate the 1-m biobarrier; percolation was observed below two of six 0.5 - $\mathrm{m}$ biobarriers. Evapotranspiration from the irrigated plots was over twice that of plots receiving ambient precipitation, but, by November 1, plants had extracted all but $30 \mathrm{~mm}$ of the supplemental water. There was clear evidence of water extraction below the biobarrier on four of $180.5-\mathrm{m}$ biobarrier subplots and one of $181-\mathrm{m}$ subplots under the fall/spring irrigation regime. In these plots, water content below the biobarrier was at least $25 \%$, indicating that a threshold water content may be required for roots to bridge a biobarrier. All plot configurations performed as expected in 1996, but significant differences among caps and vegetation type and significant interactions with irrigation treatment demonstrate the critical importance of statistical replication in studies such as this.
\end{abstract}

Keywords: Evapotranspiration, hazardous waste, landfill capping, Protective Cap/Biobarrier Experiment,

\section{JUSTIFICATION}

Shallow burial is a common method for disposing of low-level radioactive, industrial, and municipal wastes. Percolation of water into buried wastes is among the most serious problems faced by managers of such disposal sites (Healy et al. 1989, Nativ 1991), so exclusion of water must be a priority in containment designs. The presence of water may promote growth of plant roots into the waste zone and the subsequent transport of hazardous materials to aboveground foliage. Furthermore, percolation of water through the waste zone may contaminate ground water (Fisher 1986).

Various designs and recommendations for isolating wastes with protective caps have been proposed and implemented (Nyhan et al. 1990, Wing and Gee 1990, Anderson et al. 1991, 1993), but there has been no attempt to statistically compare the effectiveness and long-term stability of different designs in a large-scale replicated field experiment. Highly engineered protective caps may be very costly to construct, and their designs often fail to account for or exploit local climatic characteristics and natural processes. Furthermore, the longevity of some caps depends upon the continued integrity of manufactured materials that are critical functional components of the design.

In semiarid areas, where potential evapotranspiration (ET) greatly exceeds precipitation, it is theoretically possible to preclude water from reaching interred wastes with 1) a simple soil cap that is deep enough to store precipitation received while plants are dormant or during short duration, high intensity storms and 2) a stable plant cover that depletes soil moisture reserves during the growing season, thereby emptying the soil's

${ }^{3}$ Department of Biological Sciences, Idaho State University, Pocatello, Idaho 83209-8007 
water storage reservoir. Plants are a critical component of a protective soil cap because they extract water from the soil to depths well below those affected directly by evaporation from the soil surface.

We have demonstrated the feasibility of this soil-plant cover system at the Idaho National Engineering and Environmental Laboratory (INEEL), where $2 \mathrm{~m}$ (6 ft.) of local soil supporting a healthy stand of perennial vegetation prevented deep drainage of water even under twice the average annual precipitation (Anderson et al. 1991, 1993). However, it is possible that burrowing by small mammals or ants may decrease the water storage capacity of a soil cap and provide paths for preferential flow of water. Biological intrusion barriers (biobarriers) of gravel and cobble restrict burrowing ( $\mathrm{J}$. Laundre, unpublished data), but the impacts of such barriers on soil moisture storage and plant rooting depths are unknown.

The Protective Cap/Biobarrier Experiment (PC/BE) was designed to rigorously test the efficacy of four protective cap designs at the INEEL. The cap designs are 1) $2 \mathrm{~m}(6 \mathrm{ft}$.) of soil, 2 ) $2 \mathrm{~m}$ (6 ft.) of soil interrupted by a biobarrier $0.5 \mathrm{~m}(1.5 \mathrm{ft}$.) below the soil

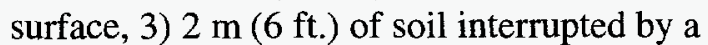
biobarrier $1 \mathrm{~m}(3 \mathrm{ft}$.) beneath the soil surface,

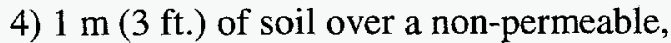

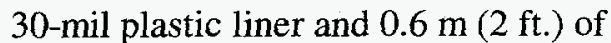
compacted clay, as recommended by the U.S. Environmental Protection Agency. The biobarrier is a $0.3-\mathrm{m}(1 \mathrm{ft}$.) layer of rock cobble sandwiched between $0.1-\mathrm{m}$ (4-in.) layers of gravel.

The experimental design is a three-way factorial split-strip plot. Irrigation (three treatments) is the strip plot factor, cap (four configurations) is the split plot factor, and vegetation (two types) is the subplot factor. These treatments are replicated three times. Each of twelve 16 X 24-m (52 X 79-ft.) plots (four per treatment) is subdivided into $8 \mathrm{X}$ 8-m (26 X 26-ft.) subplots, for a total of 72 subplots (Limbach et al. 1994). The irrigation treatments are 1) ambient precipitation only, 2) ambient precipitation augmented biweekly during the summer to double the average annual precipitation, and 3) ambient precipitation augmented to double the average annual precipitation, with half applied in late fall and half in early spring. Subplots are planted with either a monoculture of crested wheatgrass (Agropyron desertorum) or a native species mixture consisting of five shrub species, five grass species, and two forb species (Limbach et al. 1994). The experimental plots were constructed at the INEEL Experimental Field Station during the fall of 1993. During construction, a soil layer at the bottom of each plot in one replicate was sprayed with a solution of cobalt chloride and the soil layer just beneath the biobarriers or at $1 \mathrm{~m}$ ( $3 \mathrm{ft}$.) in the soil-only plots was sprayed with a solution of lithium chloride. These chemicals were emplaced as rooting depth tracers, assuming that elemental lithium and cobalt would be detected in the aboveground tissues of plants rooting to those depths.

\section{Objectives}

The ultimate objective of the Protective Cap/Biobarrier Experiment is to confidently recommend an effective, economical soil-plant cover system for interred wastes at the INEEL and climatically similar repositories. During the first three years we established vegetation and collected baseline data on plant establishment, rooting depths, patterns of soil water storage and depletion. Burrowing ants were introduced to the plots in 1996 (see Gaglio et al., this volume), and borrowing rodents will be introduced in the spring of 1997. Current plans call for application of excess irrigation until cap failure occurs (drainage through the entire cap) in the sixth year. Results from these manipulations will enable us to predict 1) the amount and seasonal distribution of precipitation that could fall on the site before a particular cap configuration would fail, and 
2) whether burrowing organisms will significantly affect cap performance under high levels of precipitation.

The specific objectives of the $\mathrm{PC} / \mathrm{BE}$ are to:

- Compare the efficacy of four protective cap designs for precluding water percolation into a buried waste zone.

- Evaluate the impact of emplacing biological intrusion barriers at different depths within a soil cap on percolation of water, plant rooting depths, and moisture storage capacity of the soil cap.

- Examine the interactions among cap design and vegetation type with regard to plant establishment and survival, changes in plant community composition and total plant cover, plant rooting depths, and patterns of soil water extraction.

- Compare vegetation development on plots receiving different irrigation treatments.

- Evaluate the efficacy of biobarriers for restricting burrowing into protective soil caps, and examine the interaction of biobarrier depth and the movement of water in soil profiles containing burrows.

- Refine recommendations for the design, construction and maintenance of protective caps at the INEEL.

The first four of these objectives were addressed during 1996.

\section{PROJECT ACCOMPLISHMENTS}

- We compared infiltration, percolation, drainage, and depletion of soil water among the four cap designs and two vegetation types under ambient precipitation and two supplemental irrigation treatments. Because failure of a solenoid valve resulted in excessive irrigation of some plots in replicate 3 , data for replicates 1 and 2 were used to estimate ET and for analysis of water remaining at the end of the season.

- We compared ET among caps, vegetation types and irrigation treatments.

- We inventoried all plants on the native species subplots and assigned a subjective vigor index to each sagebrush plant. Plant cover was estimated by point interception on seven transects per subplot; analyses of the cover data are in progress.

- The number of live sagebrush (Artemisia tridentata ssp. tridentata and ssp. wyomingensis) individuals were compared between cap types and among irrigation treatments.

- We collected plant tissue samples in 1995 for analyses of lithium and cobalt to determine whether there were differences in rooting depth among species, cap type, or irrigation treatment. Results from the analyses were inconclusive. Plants were sampled again in 1996 and will be analyzed in the spring of 1997.

- We measured predawn and midday plant water potentials and transpiration rates of selected sagebrush plants on the ambient precipitation subplots to compare water use of the two subspecies on the different caps.

\section{IMPORTANT RESULTS}

Ambient Precipitation Treatment: The wetting front associated with spring recharge of soil water reached depths from $0.6 \mathrm{~m}$ ( $2 \mathrm{ft}$.)

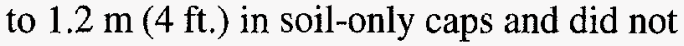
cross the biobarrier in either $0.5-\mathrm{m}(1.5-\mathrm{ft}$.) or 1-m (3-ft.) biobarrier plots. The wetting front

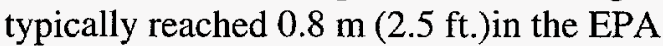


plots. Soil water was extracted to the depth of percolation in all plots, and no drainage was observed.

Summer Irrigation Treatment: In response to $310 \mathrm{~mm}$ (12 in.) of supplemental summer irrigation applied in five equal amounts at 2-week intervals, water percolated to a

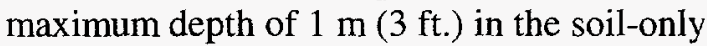
plots and 1-m (3-ft.)biobarrier plots. No percolation of water occurred below the $1-\mathrm{m}$ (3-ft.) biobarriers. The wetting front from natural winter/spring recharge did not cross any biobarrier on the summer irrigation treatment plots, but the supplemental irrigation resulted in percolation below the biobarrier in two of six $0.5-\mathrm{m}$ (1.5-ft.) biobarrier plots. Water content increased to 30-35\% above the liner in EPA plots.

At the end of the 1996 growing season (data from 1 November), average water content in the upper meter of soil for the four caps ranged from 128 to $160 \mathrm{~mm}$ (5.0 to 6.3 in.) under ambient precipitation and from 163 to $198 \mathrm{~mm}$ (6.4 to $7.8 \mathrm{in}$.) on plots receiving summer irrigation (Fig. 3). Despite these modest differences, analysis of variance revealed significant differences among caps, vegetation types, and irrigation treatments, and significant cap $\mathrm{X}$ vegetation, cap $\mathrm{X}$ irrigation, and cap $X$ irrigation $X$ vegetation interactions. Mean water content with supplemental irrigation was $32 \mathrm{~mm}$ higher than that under ambient precipitation $(\mathrm{P}<$ 0.001 ). Thus, the soil-plant cover system returned most but not all ( 280 of $310 \mathrm{~mm}$ [11.0 of $12.2 \mathrm{in.])}$ of the supplemental moisture to the atmosphere.

Fall/Spring Irrigation Treatment: In October, we applied $200 \mathrm{~mm}$ (7.9 in.) of supplemental water to the fall/spring irrigation subplots on replicates 1 and 2. Due to failure of a solenoid valve on replicate 3 , an additional $310 \mathrm{~mm}$ (12.2 in) of water were applied to those fall/spring subplots. Although drainage was observed from only 2 of these plots, it was clear from the moisture profiles that water content was at or near saturation at the bottom of the plots. Because this accidental irrigation resulted in some runoff to adjacent subplots, we included only Replicates 1 and 2 in our analysis of growing season ET and soil water content at the end of the growing season (Fig. 3).

Extraction of Water Below Biobarriers:

Soil moisture profiles provided a clear indication of extraction below the $0.5-\mathrm{m}$ (1.5 ft.) biobarriers in four of 18 subplots and below the 1-m (3-ft.) biobarrier in one of 18 subplots (Fig. 4). All five subplots were under the fall/spring irrigation treatment and had a volumetric water content below the biobarrier of at least $25 \%$ when extraction below the barrier was initiated. Four of the five subplots had native vegetation; the exception was one of the $0.5-\mathrm{m}(1.5-\mathrm{ft}$.) biobarrier subplots. No evidence of extraction was evident below the liners in EPA caps.

Data from 1995 and 1996 suggest that the lower limit of extraction of soil moisture on the $\mathrm{PC} / \mathrm{BE}$ plots may be $2 \%$ to $3 \%$ higher than the estimate of $11 \%$ for the original evapotranspiration plots (Anderson et al. 1993). This may reflect differences in compaction during construction of the two sets of plots. It does not appear that the drained upper limit is different on the PC/BE plots than the original plots. If this is the case, water storage capacity of the soil on the $\mathrm{PC} / \mathrm{BE}$ plots would be slightly lower than our original estimate of $17 \%$ by volume.

Under ambient precipitation, ET estimates were similar for the soil-only, 1-m (3-ft.) biobarrier plots, and EPA caps (Fig. 3). ET estimates for the $0.5-\mathrm{m}$ (1.5-ft.) biobarrier caps were slightly lower than those for the other caps because less water was available above the $0.5-\mathrm{m}$ (1.5-ft.) biobarriers than in the top one meter ( $3 \mathrm{ft}$.) of soil of the other plots at the beginning of the growing season. ET from the summer irrigation plots was over twice that for plots under ambient precipitation, as expected (Fig. 3). 

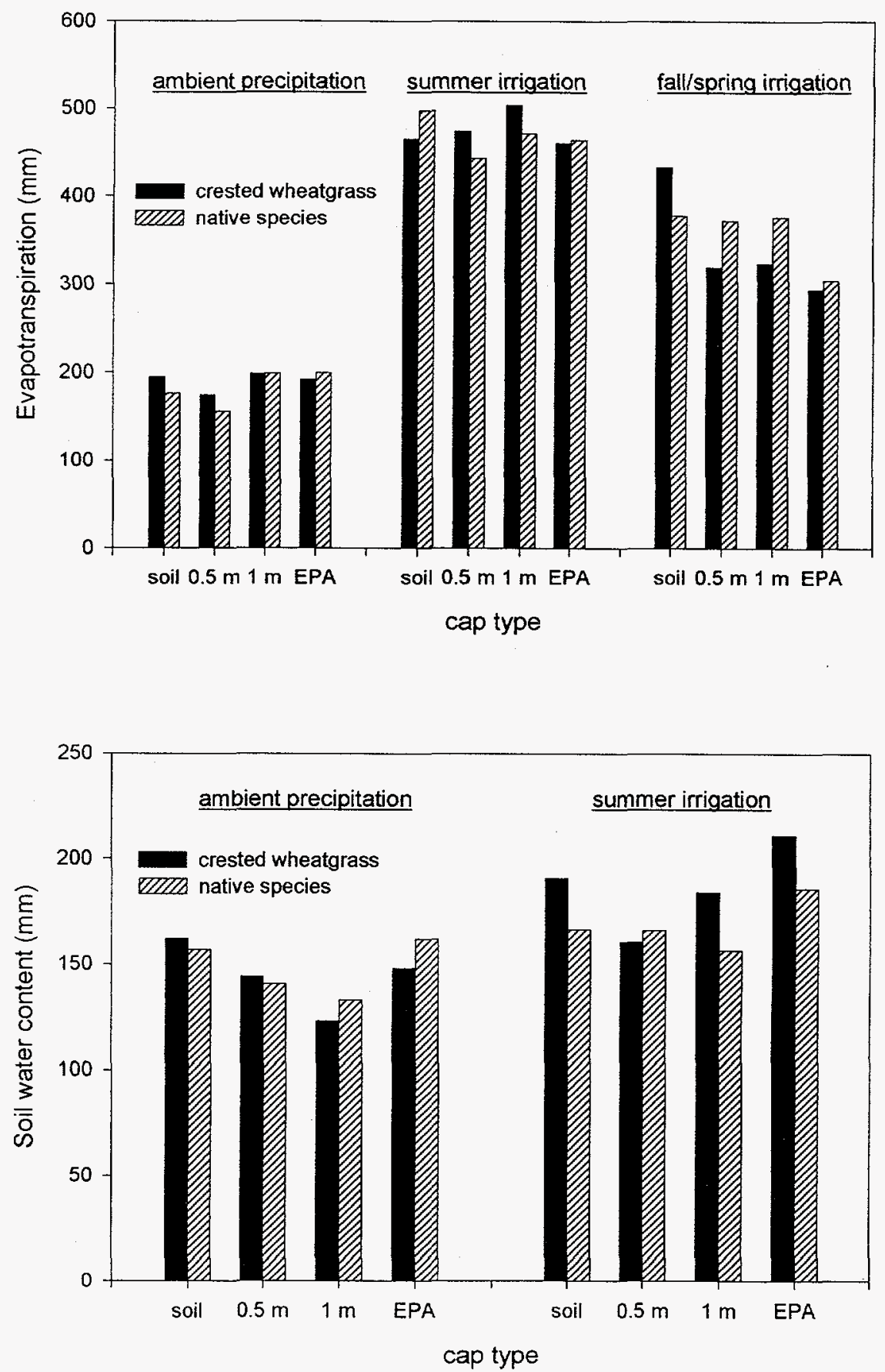

Fig. 3. Top: Evapotranspiration for the 1996 growing season for four cap designs, two vegetation types, and three irrigation treatments from the Protective Cap/Biobarrier Experiment at the INEEL. ET was calculated by subtracting total soil water content on 1 November from that on 22 March and adding precipitation received and irrigation applied between those dates. Data are means for Replicates 1 and 2. Bottom: Total soil water content in the upper $1 \mathrm{~m}$ of soil for the four cap configurations and two vegetation types under ambient precipitation and the summer irrigation treatment on 1 November 1996. Analyses are based on data for Replicates 1 and 2. 


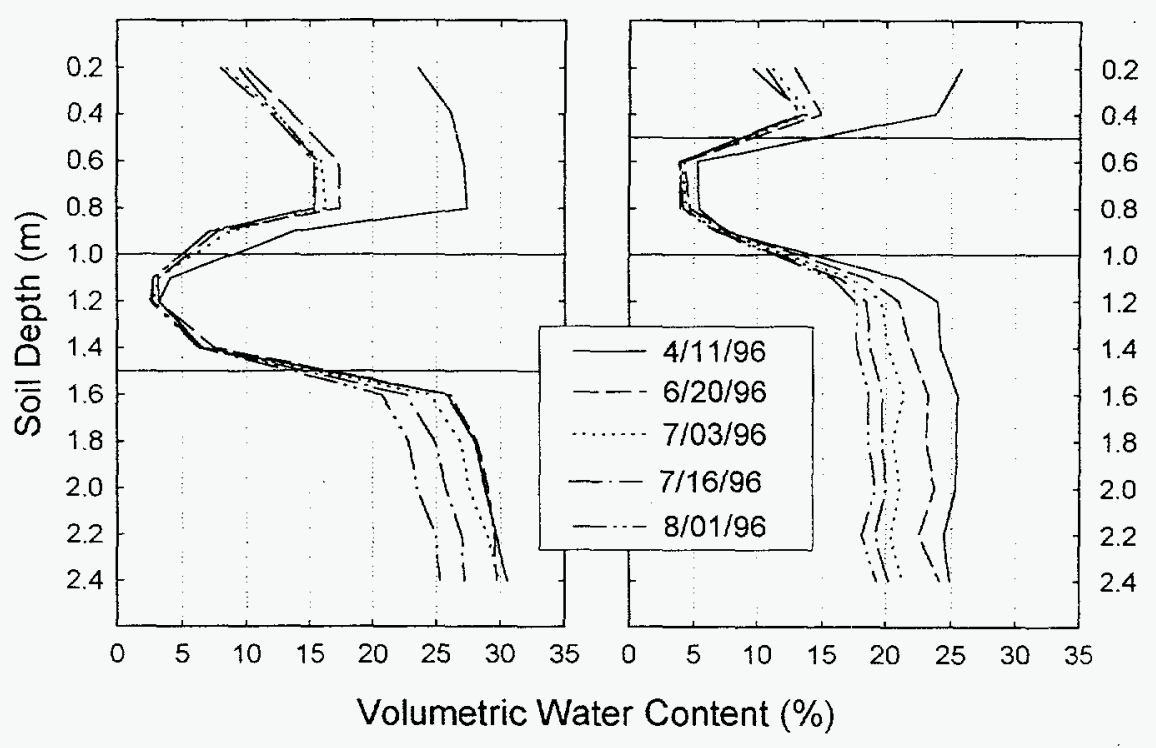

Fig. 4. Changes in soil moisture over the 1996 growing season for a 1-m biobarrier cap and a $0.5-\mathrm{m}$ biobarrier cap. In both cases, the moisture profiles indicate extraction of water by plants from the soil below the biobarrier.

Of the 4,356 individual wildings transplanted onto native species subplots (121 per subplot) in 1994, only $1,191(27 \%)$ remained alive in June 1996. There was no consistent difference or apparent trend in survival in relation to cap type or irrigation treatment. Mortality of transplants was much higher than anticipated (see Shumar and Anderson 1987); however, crested wheatgrass and various other perennial and annual species have occupied some 2,700 spaces left by plants that died. Additional recruitment has occurred in interspaces between original transplant locations, so total plant cover on the native vegetation plots remains high. There was no significant difference in the recruitment of crested wheatgrass onto the native plots among cap types or irrigation treatments.

Of 468 of each sagebrush subspecies transplanted, 227 (48\%) A. t. tridentata and $238(51 \%)$ A. t. wyomingensis were alive. There were no significant differences between species or among irrigation treatments. However, survival of both $A$. t. tridentata and
A. t. wyomingensis was higher on EPA cap plots than on soil cap plots. This may be attributable to consistently higher soil water content above the liner on the EPA plots. There was no difference in vigor between subspecies. The relatively low survival rate for sagebrush on these plots is surprising given our previous experience with transplanting this species (Shumar and Anderson 1987). Initial survival was high, as expected, and the cause of subsequent mortality is unknown.

As expected, predawn water potentials decreased over the growing season as available soil water was depleted (Fig. 5). As evidenced by the error bars in Fig. 5 , plant-to-plant variability generally increased as the season progressed, indicating increased spatial variability of moisture levels within the soil. Differential responses of the subspecies were apparent on some subplots, but the results were not always consistent on replicate plots. When significant differences 


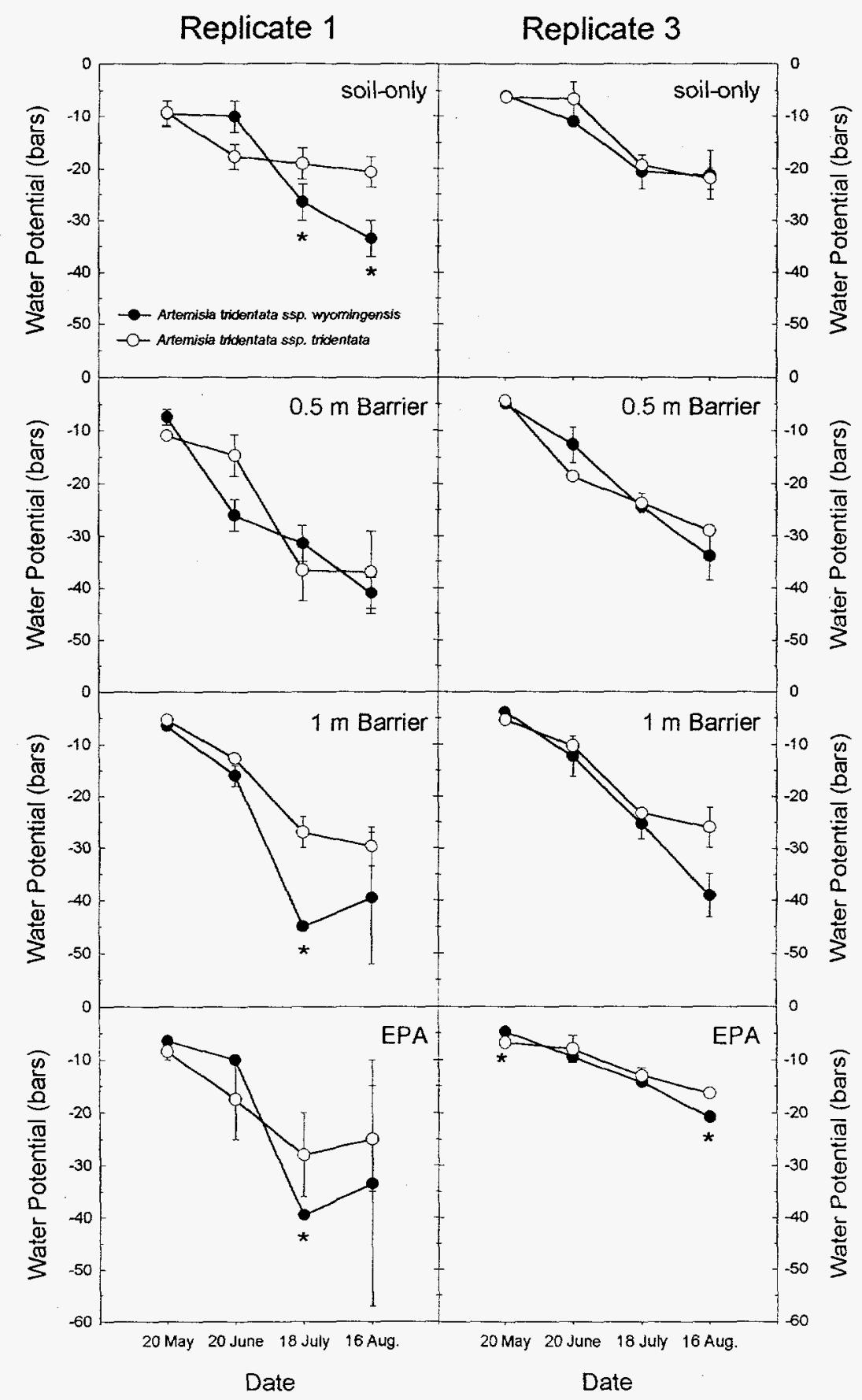

Fig. 5. Pre-dawn water potentials of selected Artemisia tridentata ssp. tridentata and A.t. ssp. wyomingensis in ambient precipitation plots of Replicates 1 and 3 during the 1996 growing season. Bars are standard errors. Significant differences $(\mathrm{P}<0.5)$ on a sampling date are denoted by *. 
were observed among stressed plants (i.e., late in the growing season), A. t. wyomingensis always had significantly lower pre-dawn water potentials than did $A$. $t$. tridentata (Fig. 5). These results suggest that $A$. $t$. tridentata, which is thought to develop a deeper root system, may have accessed water that was unavailable to $A$. $t$. wyomingensis.

Our results show that roots of some plant species are able to bridge a biobarrier, but there may be a threshold water content below which the plants are unable to detect the presence of extractable water below a biobarrier. In every case where extraction was clearly evident, volumetric water content below the biobarrier was at least $25 \%$. In general, this was the case only on the fall/spring irrigation subplots; water content on the other biobarrier subplots typically was $15-20 \%$. The results also indicate that a mixture of native species that includes deeply rooting shrubs is more likely to have roots that cross a biobarrier than is a monoculture of crested wheatgrass. However, we should caution we do not yet know the identity of the plants that have bridged the biobarrier and crested wheatgrass apparently has grown roots below one of the $0.5-\mathrm{m}(1.5 \mathrm{ft}$.) biobarriers.

No drainage was observed from any plot under the ambient or supplemental irrigation treatments, except following accidental irrigation resulting in application of $360 \mathrm{~mm}$ (14 in.) of water on the fall/spring irrigation plot of replicate 3 .

At the end of the 1996 growing season, significant differences in water content among caps, between vegetation types, and between irrigation treatments, as well as significant interactions among caps, vegetation, and irrigation treatment were found. These results demonstrate the critical importance of replication in studies such as this. They indicate that we will be able to document subtle differences in performance among cap configurations and vegetation type.

\section{PRODUCTS}

Anderson, J. E. In Press. An ecological engineering approach for keeping water from reaching interred wastes in arid or semiarid regions. Accepted for publication in the Proceedings, 1997 International Containment Technology Conference and Exhibition.

\section{LITERATURE CITED}

Anderson, J. E., W. E. Limbach, T. D. Ratzlaff. 1995. Protective cap/biobarrier experiment I: comparison of four protective cap designs for burial of hazardous waste at the Idaho National Engineering Laboratory. Pages 46-50 in T. D. Reynolds, R. C. Morris, and O. D. Markham, eds., Environmental Science and Research Foundation Annual Technical Report: April 11 - December 31, 1994. Environmental Science and Research Foundation, Idaho Falls, Idaho.

Anderson, J. E., R. S. Nowak, T. D. Ratzlaff, and O. D. Markham. 1993. Managing soil moisture on waste burial sites in arid regions. Journal of Environmental Quality 22:62-69.

Anderson, J. E., R. S. Nowak, T. D. Ratzlaff, and O. D. Markham. 1991. Managing soil moisture on waste burial sites. U.S. Department of Energy, DOE/ID-12123, Idaho Falls, Idaho.

Fisher, J. N. 1986. Hydrogeologic factors in the selection of shallow land burial for the disposal of low-level radioactive waste. Geological Survey Circular (U.S.) 973.

Healy, R. W., J. R. Gray, M. P. deVries, and P. C. Mills. 1989. Water balance at a lowlevel radioactive waste disposal site. Water Resources Bulletin 25:381-390.

Limbach, W. E., T. D. Ratzlaff, J. E. Anderson, T. D. Reynolds, and J. W. Laundré. 1994. Design and implementation of the Protective Cap/Biobarrier Experiment at the Idaho 
National Engineering Laboratory. Pages 359-377 in N. R. Wing and G. W. Gee, eds., Proceedings of the 33rd Hanford symposium on health and environment - In situ remediation: scientific basis for current and future technologies. Batelle Pacific Northwest Laboratory, Richland, Washington.

Nativ, R. 1991. Radioactive waste isolation in arid zones. Journal of Arid Environments 20:129-140.

Nyhan, J. W., T. E. Hakonson, and B. J. Drennon. 1990. A water balance study of two landfill cover designs for semi-arid regions. Journal of Environmental Quality 19:281-288.
Shumar, M. L. and J. E. Anderson. 1987. Transplanting wildings in small revegetation projects. Arid Soil Research and Rehabilitation 1:253-256.

Wing, N. R., and G. W. Gee. 1990. Protective Barrier Development: Overview. Pages 147-151 in R. H. Gray. ed., Proceedings of the twenty-eighth Hanford Symposium on Health and the Environment, Environmental Monitoring, Restoration, and Assessment: What have we learned? Pacific Northwest Laboratory, Richland, Washington. 


\title{
MITIGATING LONG TERM IMPACTS OF SMALL MAMMAL BURROWING ON THE CLOSURE OF HAZARDOUS WASTE AREAS
}

\author{
John W. Laundré ${ }^{4}$
}

\begin{abstract}
The intrusion of burrowing mammals into hazardous waste areas (biointrusion) and the subsequent transport of waste off the burial area has been shown to be a problem on older waste areas and continues to be a concern regarding future closure of current waste areas. The objective of this study is to determine the effectiveness of three types of material (biobarriers) in preventing the burrowing of small mammals into waste areas. The three materials are 1) 5- to 10-cm (1- to 2-in.) cobble, 2) chipped roofing gravel, and 3) a mixture of gravel and cobble. Townsend's ground squirrels (Spermophilus townsendii) and Ord's kangaroo rat (Dipodomys ordii) were introduced into enclosures containing $50-\mathrm{cm}$ thick layers of these materials overlaid by native soil. An additional objective was to determine if creating such a biobarrier in the presence of burrowing mammals might alter soil moisture patterns and compromise the integrity of the waste cap. After three years, there is still no evidence that the test animals have burrowed through the biobarrier layers.
\end{abstract}

Keywords: Burrowing mammals, biobarrier, landfill capping, Protective Cap/Biobarrier Experiment, soil moisture.

\section{JUSTIFICATION}

The intrusion of burrowing mammals into hazardous waste areas (biointrusion) and the subsequent transport of waste off the burial area has been shown to be a problem on older areas and continues to be a concern regarding future closure of current waste areas. Studies of burrow depths on the Idaho National Environmental and Engineering Laboratory (INEEL) have demonstrated that small mammals can potentially burrow deep enough to reach waste material within many currently closed waste areas (Reynolds and Wakkinen 1987, Laundré and Reynolds 1993). Work published by other NEEL workers has also demonstrated that small mammal burrowing has contributed to the upward transport of hazardous waste to the surface of waste areas (Arthur and Markham 1983). Consequently considerable effort is being expended on ways to mitigate the transport of waste by burrowing mammals and developing accurate risk assessments of the long term impact of small mammals on hazardous waste areas.

In FY93 a protective cap/biobarrier experiment was begun on the INEEL. The project's goal is to test the effectiveness of several possible hazardous waste disposal site covers. Incorporated into the designs to be tested are biobarriers of either gravel (EPA design) or cobble (Environmental Science and Research Foundation design). These biobarriers are designed to prevent burrowing mammals from penetrating the trench cap and act as a capillary break to limit the movement of water into the waste zone. With reference to the first property, no data are available on whether the proposed material will act as an effective biobarrier to burrowing mammals. In FY92, an effort to test the effectiveness of the proposed biobarrier material was initiated. The experimental design consists of 24 circular enclosures. Six of the enclosures function as controls; the remaining 18 contain various treatments of two barrier material as described in the methods section. Ground squirrels (Spermophilus townsendii) and kangaroo rats (Dipodomys ordii) were released into the 24 enclosures in the summer of 1992. During FY93 to FY96 the enclosures were monitored to determine if the animals have dug through the biobarrier material.

Relative to water movement, the effectiveness of abrupt soil texture changes (capillary breaks) in stopping downward

${ }^{4}$ Department of Biological Sciences, Idaho State University, Pocatello, ID 83209 
water movement is well documented. However, it is unknown what impact burrowing mammals may have on the effectiveness of a capillary break. From 1984-92, there has been a study of the effects of small mammal burrows on soil water dynamics on the INEEL. Data collected indicate that burrows increase the amount of water that enters the soil and the depth to which it can penetrate, especially during spring recharge (Laundré 1993). If a burrow extends to or through a capillary break, increased water penetration may compromise the break's effectiveness. One of the objectives of the ongoing research is to predict the impact of mammal burrows on the water storage effectiveness of a soil profile above a capillary break. From previously collected data, regression equations have been developed that predict the extent of water infiltration from burrows. These equations should be usable to predict the impact of burrows on the water holding capacity above a capillary break. However, winter precipitation (Nov-Feb) during the study years was at or below average $(<5.5 \mathrm{~cm}$ [2 in.] water). As of 1992, data were still lacking from the INEEL on the effects of burrows on water infiltration during spring recharge from above normal winter precipitation. Failure of a capillary break is most likely to occur at these higher precipitation amounts especially if followed by a rapid spring snow melt. Data from years of this worst case scenario of above normal precipitation and rapid snow melt are needed to validate the regression equations developed.

The enclosures used to test the different biobarriers will provide an additional test of the impact of burrows on soil storage capacity and data to help validate the regression equations developed. Each enclosure consists of $50 \mathrm{~cm}$ ( $20 \mathrm{in}$.) of the biobarrier material overlain by $50 \mathrm{~cm}$ ( $20 \mathrm{in}$.) of soil (silt/clay material used for waste disposal cover). The ground squirrels and kangaroo rats have constructed several burrows per enclosure in the soil. The enclosures are designed to catch adequate snow to provide sufficient moisture to fill the $50-\mathrm{cm}$ ( $20 \mathrm{in}$.) layer of soil above the capillary break in the absence of burrows. The ability of the soil profiles containing burrows to hold the prescribed amount of moisture will be compared to six control enclosures identical to the biobarrier enclosures but lacking small mammals.

The results of this work will help determine the feasibility of using biobarriers to prevent small mammals from burrowing into waste areas. If the biobarriers tested prove effective, they would valuable to the Department of Energy in its hazardous waste management efforts.

\section{Objectives}

The overall objective of this project is to test the feasibility of using biobarriers to prevent small mammals from burrowing into hazardous waste areas. This objective will be accomplished by:

- Testing the effectiveness of three potential biobarrier layers to small mammal burrowing: 1) 5- to $10-\mathrm{cm}$ (1- to 2-in.) cobble, 2) chipped roofing gravel, and 3 ) a mixture of gravel and cobble.

Two small mammal species are being used in the experiment: the kangaroo rat and Townsend's ground squirrel. These two species represent the deepest burrowing mammals on the INEEL (Reynolds and Wakkinen 1987, Laundré and Reynolds 1993). The hypothesis tested for each species is that each biobarrier layer is equally effective in preventing animals from burrowing beyond the barrier layers.

- Testing the impact of small mammal burrowing on the effectiveness of these biobarrier layers as capillary breaks to water movement into the soil.

The hypothesis being tested is that 
moisture movement beyond the capillary break during spring recharge is similar for enclosures containing small mammals and the controls.

\section{PROJECT ACCOMPLISHMENTS}

Project accomplishments for the calendar year 1996 include:

- Monitor burrowing activity of animals in the enclosures.

- Sampling of soil moisture above and below the biobarriers during the spring recharge.

- Initiation of excavation of burrows in enclosures

\section{IMPORTANT RESULTS}

- In the enclosures excavated, there is no evidence that either ground squirrels nor kangaroo rats have penetrated the biobarrier material.

- Soil moisture in the $50 \mathrm{~cm}$ (20 in.) of soil above biobarriers was significantly greater that for soil controls.

\section{PRODUCTS}

Two manuscripts were submitted in calendar year 1996 and are currently under review:

- Laundré, J. W. Effect of ground squirrel burrows on plant productivity in a cool desert environment. Submitted to the
Journal of Range Management.

- Laundré, J. W. The relationship between carbon isotope ratios and sagebrush productivity. Submitted to Oecologia.

A presentation, entitled The impact of a Shallow Biobarrier on Water Recharge Patterns in a Semi-arid Environment was developed and accepted for the 1997 International Containment Technology Conference and Exhibition to be held in St. Petersburg, Florida, February, 1997.

\section{LiTERATURE CITED}

Arthur, W. J. and O. D. Markham. 1983.

Small mammal soil burrowing as a radionuclide transport vector at a radioactive waste disposal area in southeastern Idaho. Journal of Environmental Quality 12:117-122.

Laundré, J. W. 1993. Effects of small mammal burrows on water infiltration in a cool desert environment. Oecologia 94:43-48.

Laundré. J. W. and T. D. Reynolds. 1993. Effects of soil structure on burrow characteristics of five small mammal species. Great Basin Naturalist 53:358-366.

Reynolds, T. D. and W. L. Wakkinen. 1987. Characteristics of the burrows of four species of rodents in undisturbed soils in southeastern Idaho. American Midland Naturalist 118:245-250. 


\title{
STUDIES ON THE EFFECTIVENESS OF BIOBARRIERS AGAINST HARVESTER ANT EXCAVATION OF BURIED WASTE: LABORATORY EXPERIMENTS
}

\author{
James B. Johnson and Paul E. Blom ${ }^{5}$
}

\begin{abstract}
This project examined the possibility of using a layer of gravel or layers of gravel and cobble in the soil cap over buried waste as a means of preventing ant penetration into the waste. The focus of the study was on Pogonomyrmex salinus, the dominant harvester ant on the Idaho National Engineering and Environmental Laboratory (INEEL) site. The tests were conducted in the laboratory in "ant farms" consisting of 20.3-cm (8-in) diameter PVC tube to contain soil and an arena for ant foraging. Layers consisting of 1.8 to $2.7-\mathrm{cm}(0.7$ to 1.1 -in) subangular gravel and 5 to $14-\mathrm{cm}$ ( 2 to 5.5 -in) diameter rock were incorporated into the soil column. Ant penetration to specific depths was detected by inclusion of strata of colored aquarium gravel at $25 \mathrm{~cm}(9.8 \mathrm{in})$ intervals. During 1996 we concluded tests with a $21-\mathrm{cm}(8.3-\mathrm{in})$ layer of gravel and 10-30-10 cm (4-12-4 in) of gravel-cobble-gravel. The 21-cm (8.3-in) layer of gravel did not prevent ant penetration. In five of six tests the $50-\mathrm{cm}$ (20-in) layer of gravel and cobble did prevent ant penetration.
\end{abstract}

\section{JUSTIFICATION}

Buried radioactive materials at the Idaho National Engineering and Environmental Laboratory (INEEL) could be exhumed due to animal activity. Among the organisms capable of moving buried waste are ants. Ants are numerous and taxonomically diverse in this area (Allred and Cole 1971; Blom and Clark, unpublished data), and harvester ants, Pogonomyrmex salinus Olsen, are widespread over the INEEL (Blom et al. 1991a). Pogonomyrmex salinus galleries can be extensive. Near vertical tunnels, ca. $5 \mathrm{~mm}$ $(0.2 \mathrm{in})$ in diameter, have been found as deep as $1.8 \mathrm{~m}$ (6 ft) on the INEEL. Plate-like chambers radiate from the vertical tunnels (Lavigne 1969, Blom 1990). Ant excavation of these tunnels and chambers could bring radioactive waste to the surface. It is known that they can incorporate radioactive materials into their mounds if the colony is located on or near a site with contaminated soil (Blom 1990, Blom et al. 1991b). Ant mounds and galleries are likely to influence water infiltration (Blom et al. 1994, Blom and Johnson, unpublished data), which in turn could affect redistribution of buried radioactive materials. Thus, in designing a cap for shallow waste disposal, incorporation of a layer resistant to ant excavation would be extremely beneficial. Cline et al. (1980) found that a thick layer of cobble appeared to retard penetration of various organisms into a simulated shallow surface disposal trench. In their study, three colonies of $P$. salinus were successfully transferred to the simulated trench by moving a queen and a number of associated workers. The colonies prospered for two years at which time they were excavated to determine the depth of penetration. Only one channel of a single nest could be found reaching into the cobble material, from which it was concluded that the material was an adequate biobarrier. Two confounding factors prohibit this conclusion. Placement of the barrier may have been too deep $(1.2 \mathrm{~m})$ to be confident it had been challenged given the modest size of the test colonies (1,000 - 3,000 workers) and short duration (two years) of the experimental period. It is likely that depth to barrier and time of exposure to ants had been tested and not the material itself. The ants could have easily traversed the spaces formed by the cobble given adequate opportunity and biological need.

\section{Objectives}

This study was undertaken to test several candidate materials for their ability to stop 
downward excavation of $P$. salinus. Ant colonies were transferred from the field to laboratory soil columns for the testing. In 1992-1993, 12 colonies were used to challenge 25-cm (9.8 in) thicknesses of a cobble, gravel, and cobble-gravel mixture against excavation. Based on results from these trials, subsequent years were used to examine increasing thicknesses of the gravel lens, ranging from 3 to $21 \mathrm{~cm}$ (1.2 to $8.3 \mathrm{in})$ at $3-\mathrm{cm}$ (1.2-in) thickness increments. During 1995-1996 the basic 'biobarrier' design used in the field demonstration project at the INEEL was tested. In the laboratory trials, the compound layering of the field demonstration project, $10-30-10-\mathrm{cm}$ (4-12-4 in) thick layers of gravel-cobble-gravel, respectively, stopped ant excavation.

\section{PROJECT ACCOMPLISHMENTS}

Twelve laboratory ant nest structures (Fig. 6) were packed with lake bed sediments collected south of the Radioactive Waste Management Area on the INEEL. An angular to subangular rock ranging from 1.8 $\mathrm{cm}$ to $2.7 \mathrm{~cm}$ was selected from stock found on the INEEL as an appropriate gravel. Rock, screened to a range from 5 to $14 \mathrm{~cm}$, composed the cobble classification. From these materials three treatments were tested during 1995-1996. A 21-cm layer of gravel and the materials and layering used in the biobarrier field demonstration project on the INEEL were tested in two treatments (Fig. 7). The field barrier was constructed interbedding gravel-cobble-gravel in 10-30-10-cm thicknesses, respectively. In the laboratory this biobarrier was situated to begin either at a depth of 25 or $50 \mathrm{~cm}$ in the soil column.

Ants were collected on the INEEL to establish the test colonies. The 12 laboratory structures were grouped into three blocks of four.

During the first trial (1992-1993) ant colonies were matched to nest structure by completely random assignment. In subsequent trials the blocks were used to group colony by relative size (population) being added to the column (Table 9). Once initiated, colonies were observed for six months before the columns were dismantled for direct inspection of the soil. This permitted ample time for ant excavation to well below the treatment layer depth, and accommodated the dismantling and reconstruction of nest structures for the next trial.

\section{IMPORTANT RESULTS}

Integrity of gravel thicknesses up to $21 \mathrm{~cm}$ were compromised, though, once the layer thickness reached $6 \mathrm{~cm}$ (done in previous years), excavation below the barrier was sharply reduced. With the $21-\mathrm{cm}$ gravel thickness, only one colony exhumed tracer from one depth below the barrier. Post-trial inspection of the soil indicated that two of the three colonies had excavated down to $100 \mathrm{~cm}$ (39.4 in). Again, though the barrier layer was breached, it was only with single tunnels and limited sub-barrier excavation occurred. Materials and configuration used in the field demonstration project appeared to be more successful in blocking ant excavation. None of the colonies exhumed tracer from below this 50-cm (19.7-in) thick layer (Fig. 8), and, upon dismantling, only one of the six colonies was found with workers penetrating into the upper reaches of the barrier (see similar observation by Cline et al. 1980). Though this biobarrier included a central, 30-cm (12in) layer of cobble, which alone would not be expected to deter the ants (Fig. 9), the absolute thickness of the biobarrier and its structure including a $10-\mathrm{cm}$ (4-in) layer of gravel above and below, render the results plausible. From the perspective of ant control, the overall integrity of this barrier design might be enhanced by the thickening of the upper gravel layer. It may be expected that the $10-30-10 \mathrm{~cm}$ (4-12-4 in) configuration will perform as well under field conditions. As long as the ants are able to reach depths needed for thermal and moisture regulation 


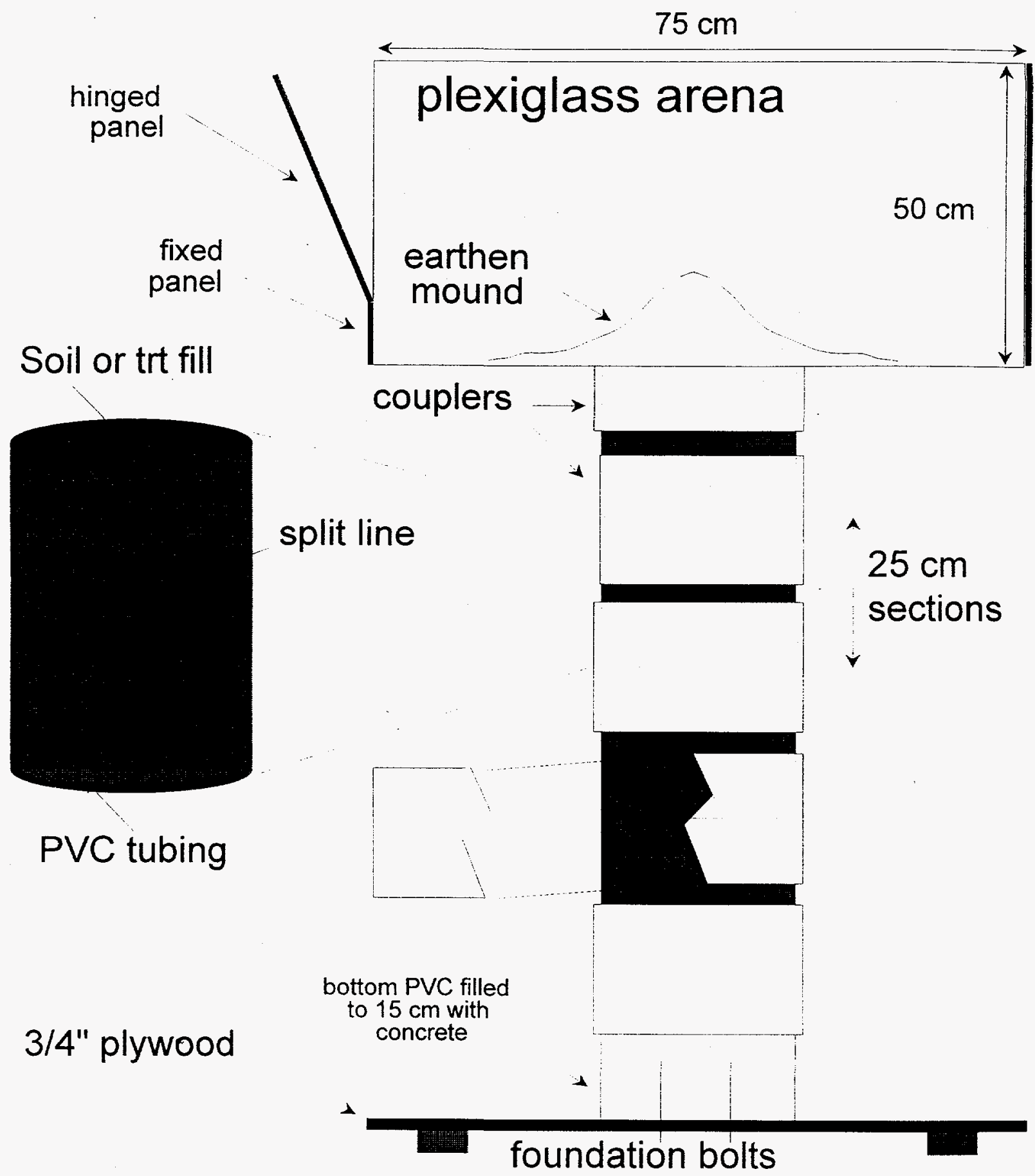

Fig. 6. Schematic of the nest structure used in laboratory testing of potential biobarriers for the exclusion of Pogonomyrmex salinus during nest excavation. 
the unrestrained lateral geometry of the field soil profile could allow for the simple volume requirements of a large colony and not provide incentive for challenging the underlying barrier. Hence, one would reason that a deeper placement (over more shallow options) in the field situation would be preferable.
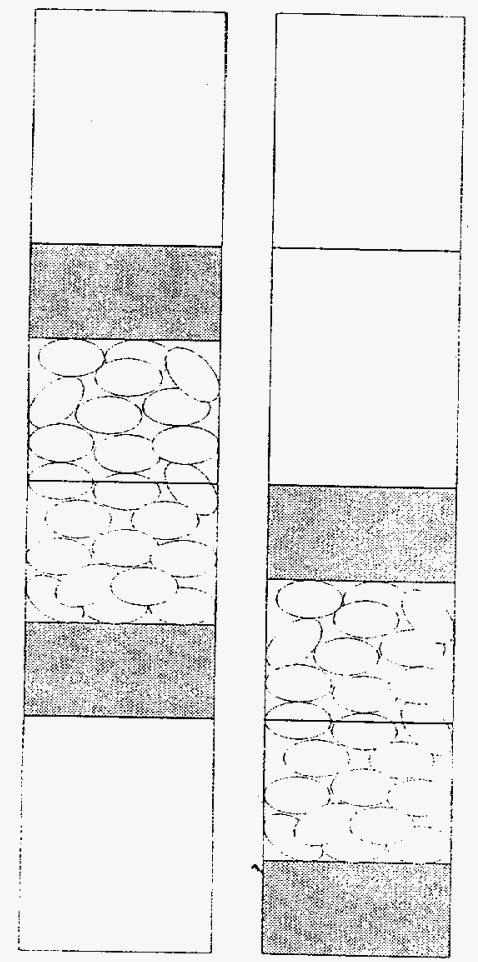

Fig. 7. Treatment configurations used in laboratory ant nest structures in 1996. Stippling indicates gravel and elliptical shapes cobble. Blank areas were filled with soil. Each section was $25 \mathrm{~cm}$ deep.

\section{LITERATURE CITED}

Allred, D. M. and A. C. Cole, Jr. 1971. Ants of the National Reactor Testing Station. Great Basin Naturalist 31:237-242.

Blom, P. E. 1990. Potential impacts on radioactive waste disposal situations by the harvester ant, Pogonomyrmex salinus Olsen (Hymenoptera: Formicidae). M.S. Thesis. University of Idaho, Moscow. 241 $\mathrm{pp}$.

Blom, P. E., W. H. Clark and J. B. Johnson. 1991. Colony densities of the seed harvesting ant Pogonomyrmex salinus (Hymenoptera: Formicidae) in seven plant communities on the Idaho National Engineering Laboratory. Journal of the Idaho Academy of Science 27:28-36

Blom, P. E., J. B. Johnson and S. K. Rope. 1991. Concentrations of ${ }^{137} \mathrm{Cs}$ and ${ }^{60} \mathrm{Co}$ in nests of the harvester ant, Pogonomyrmex salinus, and associated soils near nuclear reactor waste water disposal ponds. American Midland Naturalist 126:140-151. Blom, P. E., J. B. Johnson, B. Shafii and J. Hammel. 1994. Soil water movement related to distance from three Pogonomyrmex salinus (Hymenoptera: Formicidae) nests in southeastern Idaho. Journal of Arid Environments 26:241-255.

Cline, J. F., K. A. Gano and L. E. Rogers. 1980. Loose rock as biobarriers in shallow land burial. Health Physics 39:497-504.

Lavigne, R. J. 1969. Bionomics and nest structure of Pogonomyrmex occidentalis (Hymenoptera: Formicidae). Annals of the Entomological Society of America 62:1166-1175. 
Table 9. 1996 Assignment of ant colonies to columns and treatments, colony size (number of workers) collected in the field and eventual number added to the columns. Treatments: BB25 = 10-30-10-cm thicknesses of gravel-cobble-gravel placed at a depth of $25-75 \mathrm{~cm}, \mathrm{BB} 50=10-30$ $10-\mathrm{cm}$ thicknesses of gravel-cobble-gravel placed at a depth of $50-100 \mathrm{~cm}$.

\begin{tabular}{lccc}
\hline & & Treatment & \\
\cline { 3 - 4 } Block 1 & BB25 & BB50 & Control \\
\cline { 3 - 4 } Nest number & 11261 & 11260 & 11259 \\
Workers collected & 4376 & 5807 & 5060 \\
Workers added & 3823 & 3894 & 3763 \\
Percent mortality & 12.6 & 32.9 & 25.6 \\
Block 2 & & & \\
\hline Nest number & 11262 & 11247 & 11263 \\
Workers collected & 3991 & 3550 & 3888 \\
Workers added & 3334 & 3013 & 3093 \\
Percent mortality & 16.5 & 15.1 & 20.4 \\
Block 3 & & & \\
\hline Nest number & 11264 & 11250 & 11265 \\
Workers collected & 2604 & 3418 & 2486 \\
Workers added & 2146 & 2662 & 2111 \\
Percent mortality & 17.6 & 22.1 & 15.1 \\
\hline
\end{tabular}

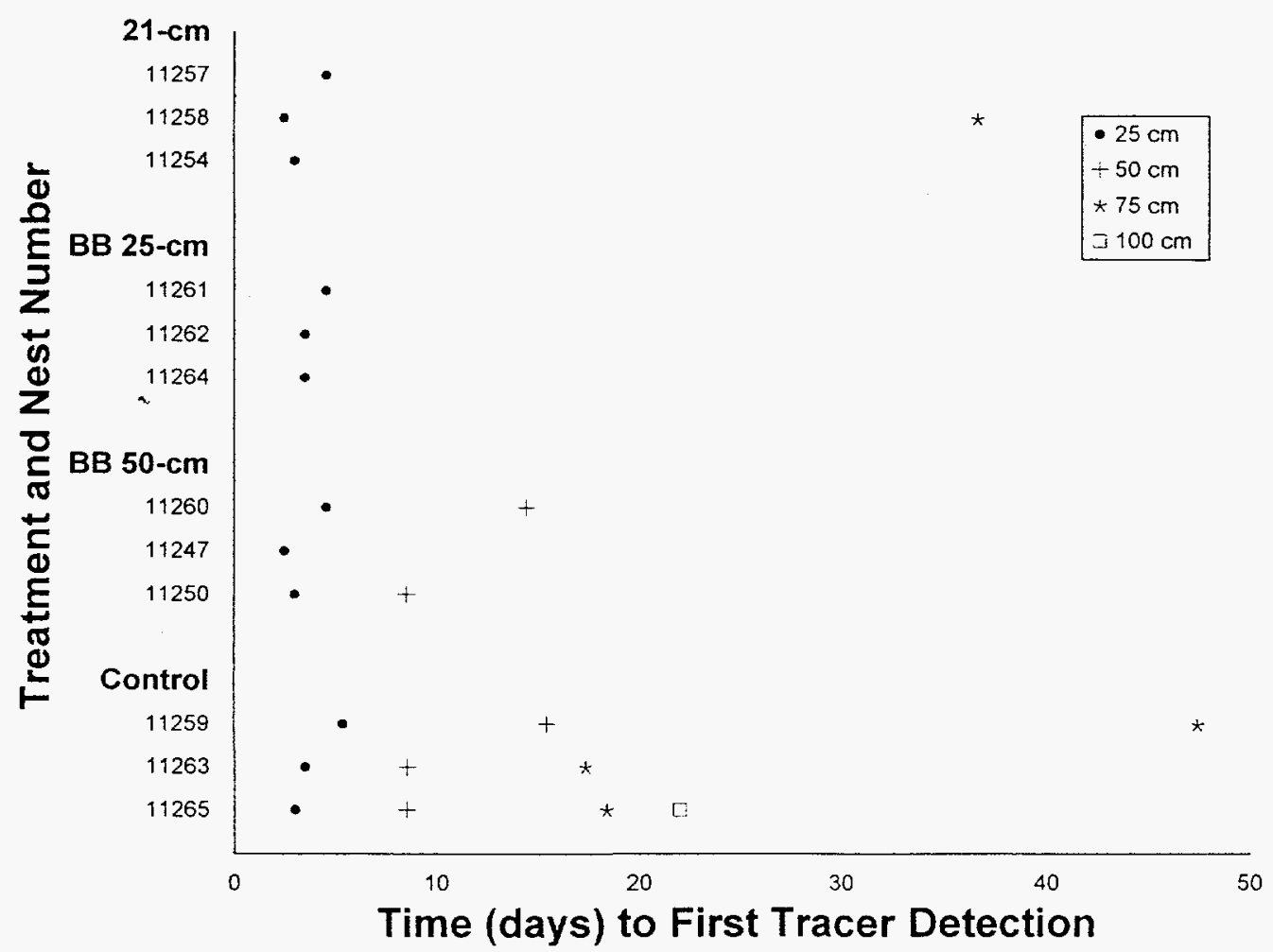

Fig. 8 1995-1996 time to exhumation of tracer gravel from $25-\mathrm{cm}, 50-\mathrm{cm}, 75-\mathrm{cm}$, and $100-\mathrm{cm}$ depths after addition of ants to column. 


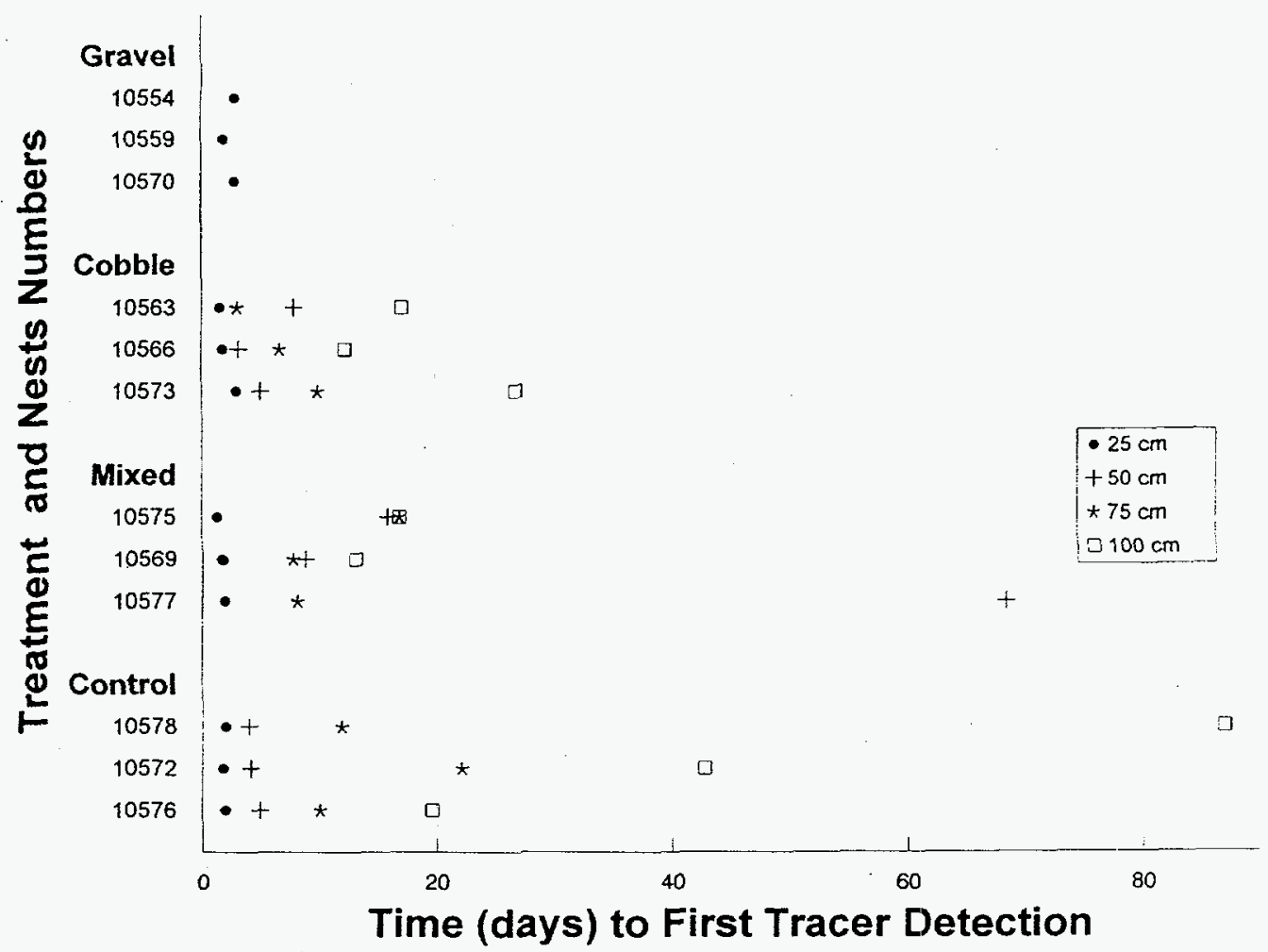

Fig. 9 1992-1993 time to exhumation of tracer gravel from $25-\mathrm{cm}, 50-\mathrm{cm}, 75-\mathrm{cm}$, and 100-cm depths after addition of ants to column. 


\title{
STUDIES ON THE EFFECTIVENESS OF BIOBARRIERS AGAINST HARVESTER ANT EXCAVATION OF BURIED WASTE: ESTABLISHMENT OF ANT COLONIES ON THE PROTECTIVE CAP/BIOBARRIER FIELD PLOTS
}

\author{
Michael D. Gaglio, William P. Mackay, Erick A. Osorio, and Ivan Iniquez ${ }^{6}$
}

\begin{abstract}
The harvester ant Pogonomyrmex salinus (Olsen) has been shown to burrow as deep as $1.8 \mathrm{~m}$ and excavate buried low level nuclear waste on the Idaho National Engineering and Environmental Laboratory (INEEL). As part of a larger protective cap/biobarrier experiment, we established $15 P$. salinus nests to experimental biobarrier and control plots. Excavations and establishment took place during late July and August of 1996. Colonies were carefully established with 2000 workers and a queen. Seven colonies were active through late September, and at least six out of the 12 in experimental plots had burrowed to the top of the biobarrier layer. Monitoring of nests will continue in the spring when the colonies become active again. More nests and time are needed to thoroughly test the biobarrier and determine the effects ants may have on the protective cap/biobarrier.
\end{abstract}

Keywords: Biobarrier, harvester ant, low level nuclear waste, protective cap/biobarrier experiment.

\section{JUSTIFICATION}

The harvester ant, Pogonomyrmex salinus (Olsen) is distributed over the entire $2305 \mathrm{~km}^{2}$ $\left(890 \mathrm{mi}^{2}\right)$ area of the Idaho National Engineering and Environmental Laboratory (INEEL) (Blom et al. 1991). Colony densities on the INEEL are around $20 \mathrm{ha}^{-1}\left(8 \mathrm{acre}^{-1}\right)$ but range from 0 to $164 \mathrm{ha}^{-1}$ (0 to $\left.66 \mathrm{acre}^{-1}\right)$ (Blom et al. 1991). Nests of $P$. salinus have been shown to burrow up to $1.8 \mathrm{~m}(6 \mathrm{ft})$ deep on the INEEL (Blom 1990). Overwintering workers of $P$. occidentalis in Wyoming were found at a depth of $2.7 \mathrm{~m}$ ( $8.9 \mathrm{ft})$ by Lavigne (1969). In Washington, Fitzner et al. (1979) noted chambers in nests of $P$. salinus (as $P$. owyheei) to be $2.7 \mathrm{~m}(8.9 \mathrm{ft})$ deep in disposal soils on the Hanford nuclear reservation. Nests of $P$. rugosus and $P$. subnitidus in southern California were found by Mackay (1981) to reach depths greater than $3 \mathrm{~m}(9.9$ $\mathrm{ft}$ ) and one such nest of $P$. rugosus extended to $4 \mathrm{~m}(13.2 \mathrm{ft})$. Because Pogonomyrmex is such an invasive creature, they create special problems for nuclear waste management on site at the INEEL. In 1990, for example, Blom showed that ant activity resulted in the exhumation of contaminated soils buried on the INEEL.

For these reasons, it is necessary to include nests of $P$. salinus in the experimental design of the protective cap/biobarrier project.

Objectives

The focus of this project was to:

- Establish 15 P. salinus colonies, each with a queen and 2000 workers, on three replicates of two versions of experimental biobarrier plots and control plots (Fig. 10).

- Determine if the ants would penetrate the gravel-cobble-gravel $(10-30-10 \mathrm{~cm}$ thick, respectively) biobarrier placed in the three replicates for barriers at $0.5 \mathrm{~m}$ and $1.0 \mathrm{~m}$ depths.

\section{PROJECT ACCOMPLISHMENTS}

From 19 July through 17 August, 1996 we excavated 25 complete $P$. salinus nests. Mound and clearing dimensions, ant population, soil temperature, and burrow depth were recorded for each nest. Ants, seeds, larvae and other organisms inhabiting the nests were collected with a garden trowel, put into small plastic containers and separated. Of the 25 excavated nests, the queen was successfully collected in 15 . To

${ }^{6}$ Laboratory for Environmental Biology, University of Texas at El Paso, El Paso, TX 79968 


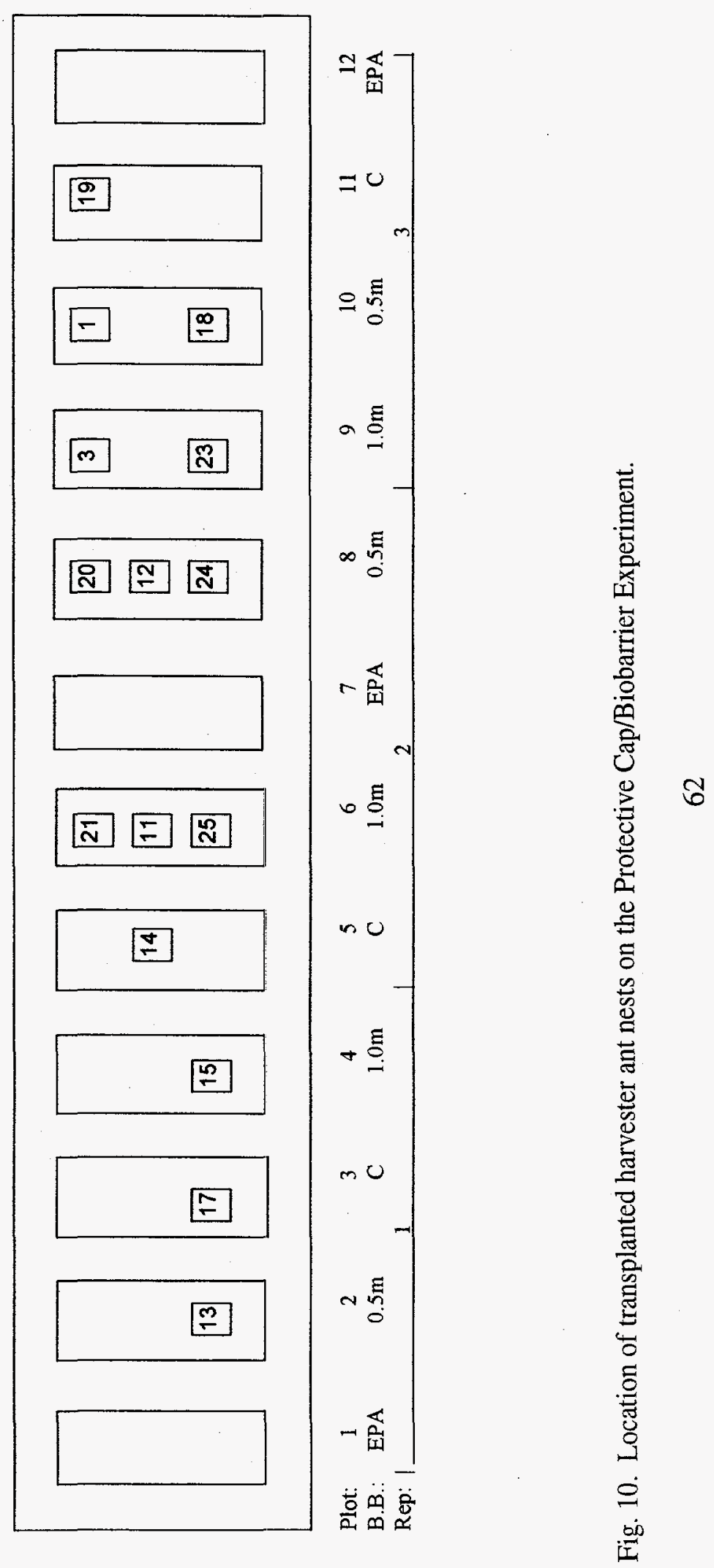


determine the mean mass of 100 ants, four replicates of 100 workers were weighed after collection of the first colony. Based on these determinations, we estimated the mass of 2000 workers. Two-thousand workers were removed from each colony from which a queen was successfully collected. The 15 colonies were introduced into the experimental plots in a prescribed order of treatment priority (Fig. 10, Table 10).

\section{IMPORTANT RESULTS}

Total population of a nest at establishment was ideally 2,000 workers. Four nests had populations of less than 2,000, the lowest being 1,250 workers (Table 10).

From a total of 25 excavated nests, we successfully transplanted 15 queens with their respective colonies to the experimental biobarrier and control plots, most of which had tracer materials incorporated in them. These tracers consisted of different colors of aquarium gravel which were placed in a $1-\mathrm{m}^{2}$ $\left(10.9 \mathrm{ft}^{2}\right)$ area above and below the biobarrier layer. Also, the tracer chemicals lithium chloride and cobalt chloride were placed at different depths in the soil of one complete cover. The occurrence of the tracer materials on the surface will help to determine burrowing depths.

Within three days, we noticed colored tracer gravel on the first nest, indicating the ants had excavated down to the top of the biobarrier at $0.5 \mathrm{~m}(1.7 \mathrm{ft})$. After that, colored gravel was seen on the surface of five more nests within one week of establishment. Two of these nests were in plots with the biobarrier at a depth of $0.5 \mathrm{~m}$ and the other three were in plots with the biobarrier at a depth of $1.0 \mathrm{~m}$. One nest in a control plot was known to be active. A total of seven nests remained active through 24 September, 1996 (Table 11).

To determine effects on the protective cap/biobarrier as a result of ant activity, the colonies must be left undisturbed for the remaining duration of the project. More colonies may also need to be introduced to simulate the natural colony densities found on the INEEL. Once these requirements are met, we will excavate the nests to look for tracer gravel and chemicals within the nest and signs of ant activity below the biobarrier. This is necessary because ants may penetrate the biobarrier without bringing tracer gravel to the surface.

\section{PRODUCTS}

This project is still in its early stages. No products were produced in 1996.

\section{LITERATURE CITED}

Blom, P. E. 1990. Potential impacts on radioactive waste disposal situations by the harvester ant, Pogonomyrmex salinus Olsen (Hymenoptera: Formicidae). M.S. Thesis. University of Idaho, Moscow. $241 \mathrm{pp}$.

Blom, P. E., W. H. Clark and J. B. Johnson. 1991. Colony densities of the seed harvesting ant Pogonomyrmex salinus (Hymenoptera: Formicidae) in seven plant communities on the Idaho National Engineering Laboratory. Idaho Academy of Science 29:28-36.

Fitzner, R. E., K. A. Gano, W. H. Rickard and L. E. Rogers. 1979. Characterization of the Hanford 300 area burial grounds. Pages 25-27 in Task IV-Biological Transport. PNL-2774. Pacific Northwest Laboratory, Richland, Washington.

Lavigne, R. J. 1969. Bionomics and Nest Structure of Pogonomyrmex occidentalis (Hymenoptera: Formicidae). Annals of the Entomological Society of America. 62:1166-1175.

Mackay, W. P. 1981. A comparison of the nest phenologies of three species of Pogonomyrmex harvester ants (Hymenoptera: Formicidae). Psyche 88: 25-74. 
Table 10. General nest data. See Fig. 1 for nest placement.

\begin{tabular}{|c|c|c|c|c|c|c|c|c|}
\hline $\begin{array}{c}\text { Nest } \\
\text { ID }\end{array}$ & $\begin{array}{l}\text { Mound dia.l } \\
\text { Mound height } \\
(\mathrm{m} / \mathrm{m})\end{array}$ & $\begin{array}{c}\text { Clear Dia. } \\
(\mathrm{m})\end{array}$ & $\begin{array}{c}\text { Depth } \\
\text { (m) }\end{array}$ & $\begin{array}{l}\text { Worker } \\
\text { Popul. }\end{array}$ & $\begin{array}{l}\text { Depth of } \\
\text { Queen } \\
\text { (m) }\end{array}$ & $\begin{array}{c}\text { Temp. at } \\
\text { Queen } \\
\left({ }^{\circ} \mathrm{C}\right) \\
\end{array}$ & $\begin{array}{c}\text { Est. } \\
\text { Popul. }\end{array}$ & $\begin{array}{c}\text { Soil } \\
\mathrm{T} \\
\left({ }^{\circ} \mathrm{C}\right) \\
\end{array}$ \\
\hline 1 & $.85 / .15$ & 2.9 & 1 & 1500 & 0.6 & & 1500 & 19 \\
\hline 2 & $.75 / .1$ & 2.5 & 1.1 & & & & & \\
\hline 3 & $.7 / .12$ & 1.7 & 1.1 & 5450 & 0.95 & 23 & 2000 & \\
\hline 4 & $.7 / .14$ & 1.55 & 1.4 & 2880 & & & & \\
\hline 5 & $.9 / .1$ & 1.3 & & & & & & \\
\hline 6 & $.9 / .15$ & 1.4 & & & & & & \\
\hline 7 & $.8 / .15$ & 3.7 & 0.85 & 900 & 0.75 & 23 & & \\
\hline 8 & $.8 / .05$ & 3 & & & & & & \\
\hline 9 & $.95 / .1$ & 3 & 1 & & & & & \\
\hline 10 & $.95 / .1$ & 3 & 0.6 & & & & & \\
\hline 11 & $.9 / .2$ & 2.2 & 1.6 & 3310 & 1.3 & 17.6 & 2000 & 20.5 \\
\hline 12 & $.5 / .08$ & 2.1 & 1.9 & 2170 & 1.3 & 18.4 & 2000 & 22 \\
\hline 13 & $.5 / .1$ & 1.9 & 1.7 & 1250 & 1.6 & 18.5 & 1250 & 20.3 \\
\hline 14 & $.35 / .1$ & 1 & 1.8 & $>4000$ & 1.3 & 18.4 & 1750 & 23.2 \\
\hline 15 & $.3 / .12$ & 1.5 & 1.7 & 1200 & 1.65 & 15.6 & 1200 & 21.8 \\
\hline 16 & $.5 / .16$ & 1.45 & 2.3 & 3820 & & & & \\
\hline 17 & $.6 / .12$ & 1.4 & 1 & $>5000$ & 0.95 & 19.5 & 2000 & 23 \\
\hline 18 & $.8 / .14$ & 2.5 & 1.5 & 5600 & 1.2 & & 2000 & 22.8 \\
\hline 19 & $.35 / .03$ & 1.5 & 2.2 & 2644 & 2 & 14.8 & 2000 & 23.8 \\
\hline 20 & $.65 / .1$ & 2.1 & & $>5000$ & 0.57 & 21.1 & 2000 & 23.5 \\
\hline 21 & $.6 / .12$ & 1.9 & 1.4 & $>4000$ & 1.1 & 15.7 & 2000 & 12.3 \\
\hline 22 & $.4 / .1$ & 1.3 & 1 & 1000 & & & & \\
\hline 23 & $.25 / .05$ & 1.4 & 1.1 & 2500 & 1 & & 2000 & 21.7 \\
\hline 24 & $.35 / .1$ & 1.7 & & $>5000$ & 0.75 & & 2000 & 23.2 \\
\hline 25 & $.25 / .05$ & 1.6 & & 4500 & 1.3 & 19 & 2000 & 22.5 \\
\hline
\end{tabular}


Table 11. Afternoon colony activity of established nests in biobarrier plots as of 19 August and 24 September 1996.

\begin{tabular}{|c|c|c|c|}
\hline Nest ID & $\begin{array}{c}\text { Status } \\
19 / 08 / 96\end{array}$ & $\begin{array}{c}\text { Status } \\
24 / 08 / 96\end{array}$ & Type $^{1}$ \\
\hline 1 & $>30$ ants, $>25$ pink gravel & 5 ants, $>75$ pink gravel & 0.5 \\
\hline 3 & $>20$ ants, 1 pink gravel & 1 ant, 4 pink gravel & 1 \\
\hline 11 & $>20$ ants & none & 1 \\
\hline 12 & $>10$ ants & none & 0.5 \\
\hline 13 & $<10$ ants & none & 0.5 \\
\hline 14 & $>20$ ants & none & $\mathrm{C}$ \\
\hline 15 & none & no ants, 1 pink gravel & 1 \\
\hline 17 & none & none & $\mathrm{C}$ \\
\hline 18 & $>10$ ants & 2 ants, 3 pink gravel & 0.5 \\
\hline 19 & $>20$ ants & 1 ant & $\mathrm{C}$ \\
\hline 20 & $>10$ ants & 1 ant, 1 pink gravel & 0.5 \\
\hline 21 & $>20$ ants & none & 1 \\
\hline 23 & $<10$ ants & none & 1 \\
\hline 24 & $<10$ ants & none & 0.5 \\
\hline 25 & $>20$ ants, 1 pink gravel & 10 ants, 2 pink gravel & 1 \\
\hline
\end{tabular}

${ }^{1}$ Values in this column represent the depth in meters to the top of the 50 -cm thick gravelcobble-gravel biobarrier that is being tested. " $\mathrm{C}$ " is the control plot. 


\title{
SOIL SUBSIDENCE AND SNOWMELT EROSION ON WASTE DISPOSAL SITES
}

\author{
James P. Dobrowolski and Eric K. Duffin ${ }^{7}$
}

\begin{abstract}
Soil settling was measured in spring and fall on all capping designs, irrigation regimes, and vegetation covers at the Protective Cap/Biobarrier Experiment plots. Soil settling was less than the $1.0 \mathrm{~cm}$ criteria established a priori for ecological significance. Soil elevations were not different among treatments within seasons nor within treatments among seasons. Naturally occurring snowfall, snow redistribution, and snowmelt erosion processes were measured on a real-time basis. A physically based component model was tested and parameterized to describe the processes of melt infiltration and runoff production as they might occur at the Subsurface Disposal Area of the Radioactive Waste Management Complex on the Idaho National Engineering and Environmental Laboratory. Some basic relationships between simulated and natural snowfall were established. We: attempted to quantify the melting rate, runoff/infiltration rate and the potential for erosion under two rainfall and temperature treatments between natural and simulated snow under the same initial frozen soil conditions. Parameter estimation improvements were made to a snow melt model for sagebrush-steppe rangelands. Climate and site data were entered into the Water Erosion Prediction Project (WEPP) model to provide some predictive power for water erosion.
\end{abstract}

Keywords: snowmelt erosion, rain-on-snow, soil settling, subsidence, trench caps.

\section{JUSTIFICATION}

Low-level radioactive wastes are buried beneath a shallow soil mantle at the Subsurface Disposal Area at the Idaho National Engineering and Environmental Laboratory (INEEL). These disposal sites must be designed to withstand the normal geomorphological processes that occur in a sagebrush-steppe ecosystem. Some of these processes include soil erosion induced by wind and water, disruption of the soil surface from freeze-thaw and shrink-swell cycles, and soil settling after waste burial (Cooke et al. 1973). The impact of these processes varies from year to year, according to the climatic patterns specific to the area. Our investigations of soil settling and erosion are designed to complement other Foundation research that aims to comprehensively define, and ultimately resolve, the effects of environmental factors that compromise waste management success and environmental restoration efforts.

Soil settling (subsidence) is a common occurrence at shallow-land burial sites, including the Subsurface Disposal Area at the INEEL Radioactive Waste Management
Complex. Regular inspections and ongoing corrective actions are required to maintain the integrity of the soil cover over waste materials. Soil settling is the result of a combination of geomorphic forces which are directly and indirectly influenced by physical and biological factors. Paramount among these are subsurface features, including voids and rock barriers, and soil moisture content, which is influenced by precipitation and plant cover. The field scale research plots at the Protective Cap/Biobarrier Experiment include four different subsurface barrier designs, three precipitation regimes, and two vegetative covers. Comparisons of soil settling among these treatments after the maximum period of moisture infiltration in the spring, and again in the fall when soils are at the lower limit of extraction ("wilting point") can identify subsurface structures and plant cover that reduce soil settling under various precipitation patterns. Incorporating these results into final cover designs may retard soil settling and consequently improve the performance of covers over wastes and and reduce long-term shallow-land burial site maintenance costs.

Previous study has shown that lakebed

${ }^{7}$ Department of Rangeland Resources and Ecology Center, Utah State University, Logan, UT 84322-5230 
sediments, frequently used to cover wastes at the INEEL, have some inherent protection from the erosive forces of summer storms. This is due to the relatively high cohesiveness of clay loam soils (Goff et al. 1994).

However, summer thunderstorms are not the greatest erosive threat to trench caps. Because snowfall provides approximately $45 \%$ of the annual precipitation on the INEEL, the erosive potential of overland flow is greatest in the spring during periods of rain and rapid snow melt on partially thawed ground. This is especially true for the weakly structured lakebed sediment soils at the INEEL (Zuzel et al. 1982, Papendick et al. 1983).

Soil erosion induced by snow melt runoff is dependent upon two main factors: 1) the rate at which snow melts onto the soil surface (determined by energy fluxes into the snow pack and the physical composition of the snow pack) and 2) the frost condition of the soil surface. In the Idaho sagebrush-steppe, interrill erosion is significantly influenced by freezing and thawing cycles during snow melt (Blackburn et al. 1990). Freeze-thaw and shrink-swell cycles can disrupt soil surface structures and make them more susceptible to erosion. Repeated freeze-thaw events can saturate the soil surface with water drawn upward from underlying horizons during each cycle. Surface soil aggregates can also break down during this process, increasing their susceptibility to erosion (Blackburn et al. 1990). Hart and Loomis (1982) reported that soil loss on bare mountain plots in northern Utah was more dependent on the rate of snow melt than the total volume of runoff. Sudden periods of high-intensity snow melt produced by increased temperature and rain-on-snow events can result in severe erosion (Zuzel et al. 1982).

To accurately predict the snow melt erosion impact, we need to measure the physical condition of the local snow pack and the energy fluxes incident on it. We also need to monitor the properties of the soil surface and near surface layers during the same period. These measurements can be used to characterize accurately the processes of snow melt infiltration, runoff, and erosion on simulated waste burial sites at INEEL. These date are needed to assess the long-term effectiveness of various cap designs at shallow-land waste disposal sites.

\section{OBJECTIVES}

Our 1996 objectives in relation to the Protective Cap/Biobarrier Experiment (PC/BE) were to:

- Continue to characterize the PC/BE surface during spring and fall using tachometry (laser electronic distance measurement) without interfering with other $\mathrm{PC} / \mathrm{BE}$ research efforts.

- Compare data within seasons among the different barrier designs, vegetation covers, and precipitation regimes.

- Compare data among seasons within each combination of barrier, vegetation, and precipitation.

Our 1996 objectives for the Simulated Trench Cap Erosion Plots were to:

- Continue to document the natural deposition of snow and redistribution mechanisms associated with available snow melt volumes.

- Continue to measure the controls on snow melt (radiative versus turbulent exchange) and identify the mechanisms associated with the snow ripening process.

- Monitor the process of melt infiltration, three-dimensional flow paths, and subsequent runoff production.

- Estimate the volume of runoff and 
sediment production from rain-on-snow events.

- Model the snow deposition, melt, and runoff processes that interact with surface cover treatments, and that are meaningful to the INEEL experimental site.

\section{PROJECT ACCOMPLISHMENTS}

\section{Soil Settling \& Subsidence}

We collected soil settling data for the $\mathrm{PC} / \mathrm{BE}$ during the dormant and growing seasons. Efforts included data management, analyses, and construction of threedimensional contour/surface maps of the $\mathrm{PC} / \mathrm{BE}$.

\section{Snow Melt Erosion}

In support of the snow melt erosion experiment we:

- Collected data (averaged over 10-minute intervals) on air temperature, relative humidity, wind speed, incoming net radiation, outgoing net radiation, and surface albedo.

- Collected winter data, averaged over 60-minute intervals, for soil temperatures (10-cm increments to $1 \mathrm{~m}$ ), soil heat flux, snow depth and precipitation.

- Used these data to define parameters for a snow melt and sublimation model (Tarboton 1994).

- Continued to make improvements to reduce down-time of the automated data collection system.

- Continued to maintain the plots, improve plot boundaries to restrict overland flow onto the plots, repair damaged equipment, and upgrade some instruments.

- Applied simulated rainfall at an intensity of $10.16 \mathrm{~cm} \mathrm{hr}^{-1}$ and two water temperatures $\left(1.2\right.$ and $\left.0.8{ }^{\circ} \mathrm{C}\right)$ to the natural snow cover, simulated snow cover (10-year average depth and 30-year maximum depth), and a saturated exposed soil experiencing diurnal freeze/thaw cycles. Air temperatures were maintained at greater than $0{ }^{\circ} \mathrm{C}$ with a forced air furnace to simulate a Chinook warm wind condition. We collected runoff at two minute intervals for 30-min and samples were vacuum filtered to determine suspended sediments. Suspended sediments were used as an index to interrill soil erosion.

- Collected surface soil to isolate plot variability using aggregate stability, soil texture, bulk density and soil water content at two depths as indicators.

- Fixed different batches of snow (natural and simulated) and compared crystal structure, grain size, and melt characteristics.

\section{IMPORTANT RESULTS}

Soil Settling Surveys

- Soil settling continued to be uninfluenced by vegetation cover type or irrigation regime.

- Plot elevations remained similar over the growing season (Fig. 11).

With several years data, we will be able to analyze the differences in settling rates for biobarrier types using repeated measures analysis of variance. 

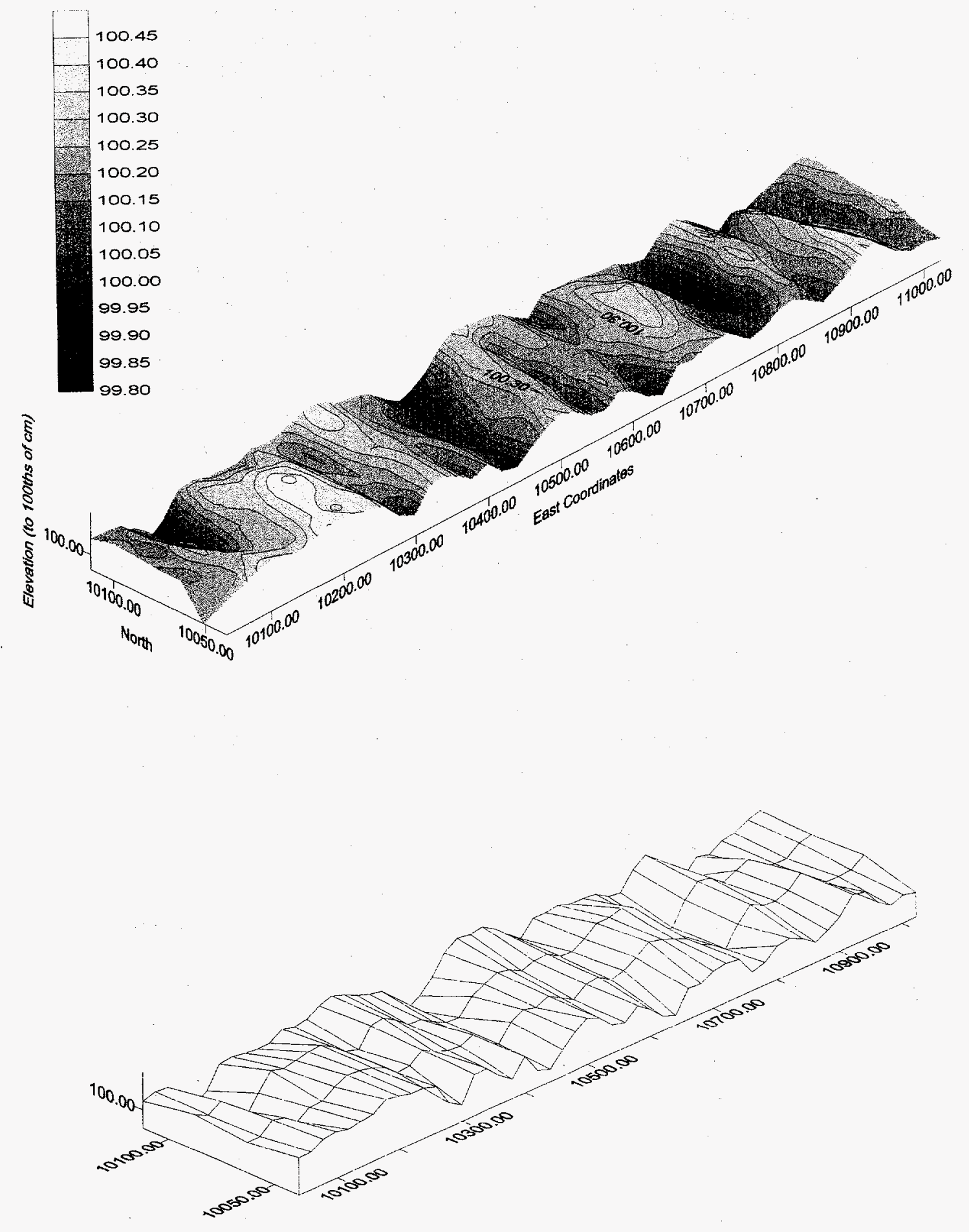

Fig. 11. Surface/contour map of the PC/BE taken during the growing and dormant seasons, 1996 $(n-350)$. North and east coordinate horizontal distances are in feet. North coordinate axis is slightly exaggerated. 


\section{Rainfall Simulation on Snow Experiment}

No significant differences were noted in aggregate stability, soil texture, and bulk density among rainfall simulation dates (February 9-March 2, 1996). Temporal changes in surface water content $(0-5 \mathrm{~cm}$ depth) were identified as the sampling period progressed (Table 12). These changes

followed a typical post -winter drying trend at INEEL.

The greatest interrill erosion resulted from simulated rainfall on nearly saturated exposed soil experiencing diurnal freeze/thaw, regardless of water temperature. Freeze/thaw cycles occurred each day 10 days prior to the rainfall simulation treatment. This likely resulted in a lack of cohesiveness and greater buoyancy in the surface and near-surface soil particles, permitting greater suspension and entrainment in runoff.

Rainfall simulation on natural snow cover produced less interrill erosion than exposed soil plots, although soil water contents were greater on natural snow plots. Surface temperatures were greater for the exposed soil versus natural snow plots $\left(3.05^{\circ} \mathrm{C}\right.$ and -0.67
${ }^{\circ} \mathrm{C}$, respectively), likely decreasing cohesiveness due to melting of the surface soil particles on exposed soil plots. Snow density, depth, and liquid water content were not different between rainfall simulations with different water temperatures.

Runoff and interrill erosion were least from simulated rainfall treatments on simulated snow. Greater snow density and colder snow ternperatures likely reduced the opportunity for runoff, most simulated rainfall appeared to infiltrate, percolate and freeze before being expressed at the soil surface. Pre- and post-rainfall simulation values for snow water equivalent (SWE) on simulated snow plots revealed that of the $5.08 \mathrm{~cm}$ of rainfall applied, $35.4 \%$ remained in the pack after rainfall ended.

Crystal analysis of natural versus simulated snow showed that grain shape and size was affected by temperature during the production of the snow and melting cycles. Natural snow, produced at cold temperatures but experiencing multiple melt episodes followed by freezing was very irregular when compared with snow produced at warmer temperatures $\left(>-7^{\circ} \mathrm{C}\right)$. Colder simulated

Table 12. Summary of rainfall simulation plot characteristics and results.

\begin{tabular}{|c|c|c|c|c|c|c|c|}
\hline Soil Condition & Treatment & $\begin{array}{c}\text { Simulated } \\
\text { Rain } \\
\text { Temp } \\
\left({ }^{\circ} \mathrm{C}\right) \\
\end{array}$ & $\begin{array}{l}\text { Air } \\
\text { Temp } \\
\left({ }^{\circ} \mathrm{C}\right) \\
\end{array}$ & $\begin{array}{c}\text { Soil } \\
\text { Surface } \\
\mathrm{H}_{2} \mathrm{O} \\
\text { Content } \\
(\%) \\
\end{array}$ & $\begin{array}{c}\text { Snowpack } \\
\text { Temp } \\
\left({ }^{\circ} \mathrm{C}\right) \\
\end{array}$ & $\begin{array}{c}\text { Soil } \\
\text { Surface } \\
\text { Temp } \\
\left({ }^{\circ} \mathrm{C}\right) \\
\end{array}$ & $\begin{array}{l}\text { Interrill } \\
\text { Erosion } \\
\left(\mathrm{kg} \mathrm{ha}^{-1}\right)\end{array}$ \\
\hline Thawed & & 11.80 & 12.8 & 4.78 & & 17.79 & 622.28 \\
\hline Natural Snow & Warm & 10.72 & 4.20 & 25.24 & 2.56 & 0.50 & 747.63 \\
\hline Natural Snow & Cold & 2.19 & 3.70 & 35.65 & 1.60 & -0.32 & 380.90 \\
\hline $\begin{array}{l}\text { Simulated } \\
\text { Snow }\end{array}$ & 30 Yr. Max & 12.55 & 5.70 & 18.12 & 1.20 & 0.40 & 126.37 \\
\hline $\begin{array}{l}\text { Simulated } \\
\text { Snow }\end{array}$ & 10 Yr. Avg & 12.02 & 5.50 & 17.69 & 0.80 & 2.26 & 161.96 \\
\hline $\begin{array}{l}\text { Sat/Frozen } \\
\text { Soil }\end{array}$ & Warm & 10.83 & 4.80 & 20.86 & & 3.92 & 7047.53 \\
\hline $\begin{array}{l}\text { Sat/Frozen } \\
\text { Soil } \\
\end{array}$ & Cold & 2.40 & 4.50 & 25.57 & & 1.80 & 8694.64 \\
\hline
\end{tabular}


snow collected at INEEL would be classed in Magono and Lee's (1966) class I4, Irregularmiscellaneous. At warmer, natural snow temperatures, the snow consisted of grain clusters corresponding to the International Classification (Colbeck et al. 1990) class 6b. This type of snow is normally caused by several melt-freeze episodes. From measurements of the specific surface areas of the two types of snow, the surface area of the colder form of snow would be expected to be larger. The colder form of snow would metamorphose into grain clusters quickly at the onset of melting. Thus the simulated snow formed at colder temperatures was not as "melt ready" as the natural snow.

We used the erosion levels measured for partially frozen soils to calculate the time it would take for a 2-m thickness of native INEEL soils to erode due to rain on snow events. We based our calculations on using the following assumptions which represent severe conditions which are unlikely to occur simultaneously year after year:

- The maximum recorded monthly precipitation levels for February (60.96 $\mathrm{mm}$ ) and March (51.56 mm) occur as a single continuous rainfall event every year.

- The storm event would occur at the same high intensity level used in rainfall simulations.

- The storm event would occur on soils that were saturated and experiencing diurnal freeze-thaw cycles.

Under these conditions, we estimate it would take over 1300 years to erode a 2-m soil cap, which is recommended for covering buried low-level wastes at the INEEL.

Tarboton's (1994) snow melt model was parameterized for INEEL near EBR-1 using meteorological runoff and sediment production data from 1994-1996. Examples of model results are shown for the snow season in 1996 (Table 12, Fig. 12) and during the 1996 snow melt period only (Table 12 , Fig. 13). Tarboton's model significantly overestimated the cumulative daily melt, predicting runoff nearly three time greater than measured runoff. Parameter sensitivity analyses continue. It appears that the model has difficulty in properly estimating the energy content of the snowpack. Specifically, the thermal interactive layer of the soil is poorly represented. We will use our data to improve this section of the model. Interrill erosion values presented in the figures were measured during the 1996 snow melt season.

We evaluated the Water Erosion Prediction Project (WEPP) model (Laflen et al. 1994) using the meteorological, slope and soils data from the EBR-1 site. Longer-term meteorological and plant growth data are required to have WEPP predict erosion with greater accuracy than the Universal Soil Loss Equation (USLE). Basic improvements must be made to the WEPP model in terms of snow melt generated runoff. The winter/spring period is lacking in appropriate algorithms for the processes involved in snow melt and potential runoff from rangeland systems.

\section{PRODUCTS}

Efforts at the PC/BE resulted in improved data management techniques and construction of three-dimensional contour/surface maps.

Rainfall simulation on simulated and natural snow showed that simulated snow likely requires multiple episodes of melting and freezing before it will resemble natural snow at INEEL. Using runoff data collected from plots covered with simulated snow will likely underestimate the amount of snow melt erosion possible under similar natural conditions. In contrast, the use of our improved Tarboton model will overestimate snow melt runoff and represents a very conservative approach. 


\section{Snowmelt Erosion - 1996}

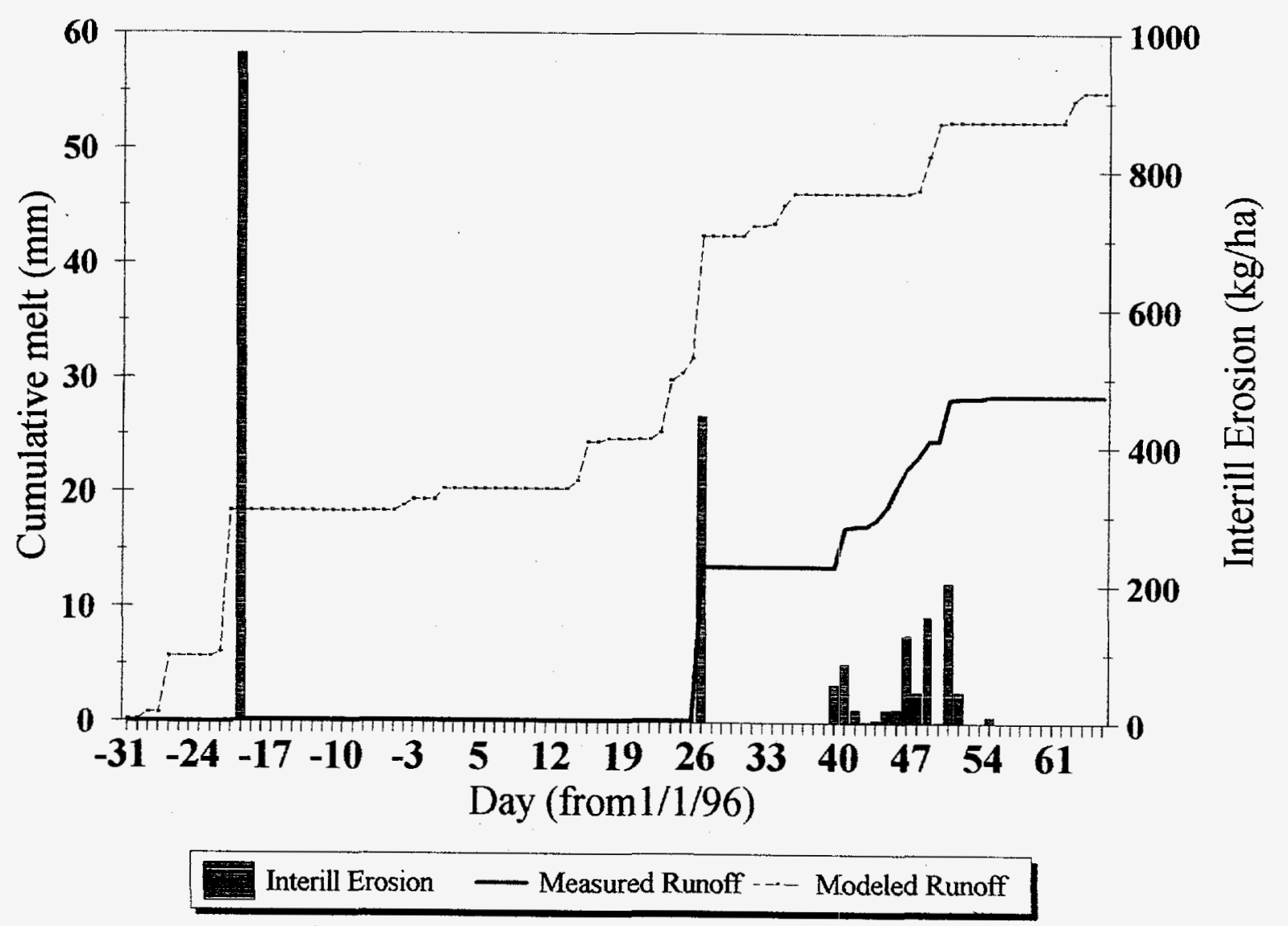

Fig. 12. Comparison of cumulative snow melt runoff for predicted (Tarboton 1994) and measured during the complete snow season in 1996. Interrill erosion is measured from simulated waste burial trench caps near EBR-1 at INEEL. 


\section{Snowmelt Erosion}

\section{Spring Snowmelt Period - 1996}

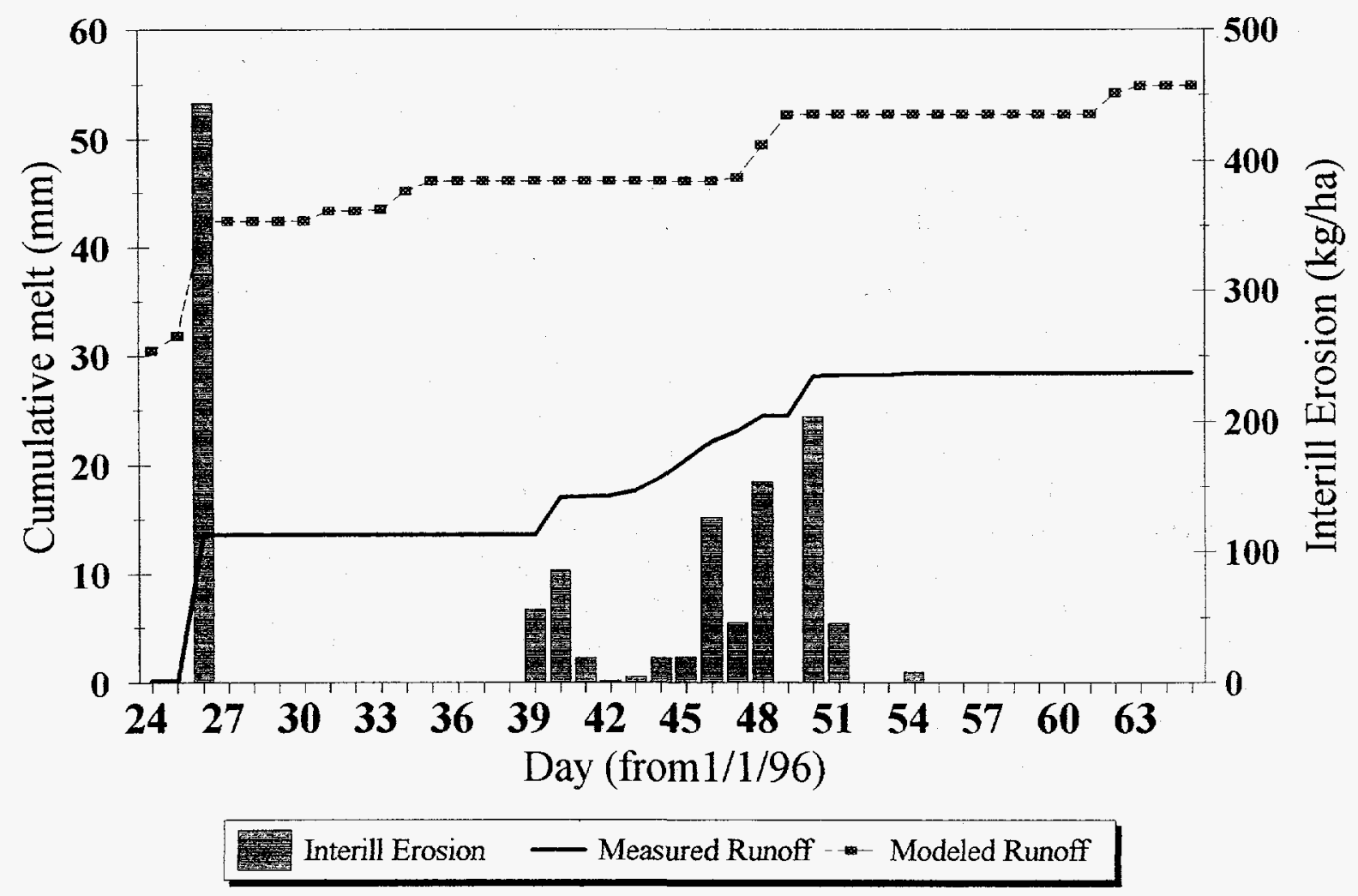

Fig. 13. Comparison of cumulative snow melt runoff for predicted (Tarboton 1994) and measured during the spring snow melt period only in 1996. Interrill erosion is measured from simulated waste burial trench caps near EBR-1 at INEEL. 
Presentations

This research was presented in two venues:

- Faculty/graduate student seminar at Utah State University.

- Foundation annual PC/BE status and planning meeting.

\section{Tangibles}

- A predictive model was finalized for snow melt runoff from waste burial sites at INEEL.

- An assessment of the use of simulated snow for runoff/erosion estimates was accomplished.

\section{LITERATURE CITED}

Blackburn, W. F., F. B. Pierson, and M. S. Seyfried. 1990. Spatial and temporal influence of soil frost on infiltration and erosion of sagebrush rangelands. Water Resources Bulletin 26:991-997.

Colbeck, S., E. Akitaya, R. Armstrong, H. Gubler, J. Lafeuille, K. Lied, D. McClung and E. Morris. 1990. The international classification for seasonal snow on the ground. International Committee on Snow and Ice (IAHS), World Data Center for Glaciology, University of Colorado, Boulder, Colorado. 23 pp.

Cooke, U. C. and A. Warren. 1973. Geomorphology in Deserts. University of California Press, Berkeley and Los Angeles. 374 pp.
Goff, B. F., G. C. Bent, and G. E. Hart. 1994. Influence of rainfall intensity on the interrill erodibility of two rangeland soils. Transactions of the ASAE 37:1445-1448.

Hart, G. E. and S. A. Loomis. 1982. Erosion from mountain snowpack melt. Soil and Water Conservation 37:55-57.

Laflen, J. M., D. C. FLanagan, M. A. Weltz, J. J. Stone, and J. C. Ascough, II. 1994. The WEPP model and its applicability for predicting erosion on rangelands. Pages 11-22 in W. H. Blackburn, F. B. Pierson, Jr., G. E. Schumann and R. Zartman, eds., Variabilty in rangeland water erosion processes. Special Publication No. 38. Soil Science Society of America, Madison, WI.

Magono, C. and C. W. Lee. 1966. Meteorological classification of natural snow crystals. Journal of the Faculty of Science, Hokkaido University, Japan Ser, VII, 11(4).

Papendick, R. I., D. K. McCool, and H. A. Krauss. 1983. Soil conservation: Pacific Northwest A.gronomy Monograph Number 23. American Society of Agronomy, Madison, WI. $622 \mathrm{pp}$.

Tarboton, D. G. 1994. The source hydrology of severe sustained drought in the southwestern United States. Journal of Hydrology 161:31-69.

Waltham, A. C. 1989. Ground subsidence. Chapman and Hall, New York. 202 pp.

Zuzel, J. F., R. R. Allmaras, and R. Greenwalt. 1982. Runoff and soil erosion on frozen soils in northeastern Oregon. Journal of Soil Water Conservation $37: 352-354$ 


\title{
DISTRIBUTION, ABUNDANCE, AND HABITAT OF THE PYGMY RABBIT ON THE IDAHO NATIONAL ENGINEERING AND ENVIRONMENTAL LABORATORY
}

\author{
John W. Laundré, Laura T. Heady, and Kate I. Gabler ${ }^{8}$
}

\begin{abstract}
The lack of information on pygmy rabbits (Brachylagus idahoensis), coupled with continuous loss of sagebrush habitat throughout its range, resulted in its classification as a C2 species. In 1996, this classification category was dissolved by the U.S. Fish and Wildlife Service, and pygmy rabbits now fall under the general category of "species of special concern." We are conducting a study of pygmy rabbit distribution, abundance, habitat use, and behavior to develop a habitat suitability index (HSI) as a valid predictor of possible pygmy rabbit occurrence. The HSI could assist preparation of NEPA documentation for proposed development sites on the Idaho National Engineering and Environmental Laboratory (INEEL). As the project is ongoing, most of the results presented here are still preliminary. Radiotelemetry data suggest that male home ranges may be larger than those used by females. Both male and female home range use patterns indicate distinctions between areas of high, medium, and low use. Vegetation, soil, and topography at these areas will be used to characterize critical habitat. Data analyzed thus far indicate shrub heterogeneity within the area surrounding the burrow; significant trends in both shrub height and density were observed. Similar analyses will be performed for all use-level areas. Data collected via radiotelemetry and camera traps suggest daily activity peaks around sunset and sunrise, with high levels of activity also continuing throughout the morning hours.
\end{abstract}

Keywords: Brachylagus idahoensis, habitat, pygmy rabbit, radiotelemetry, sensitive species, species distribution.

\section{JUSTIFICATION}

The pygmy rabbit is the smallest North American rabbit species (Dobler and Dixon 1990 ) and is the only rabbit native to North America that digs its own burrows (Wash. Dept. Fish and Wildlife 1995). Historically it had a limited distribution within areas of the Great Basin desert and some adjacent areas of the Intermountain West. It is considered a sagebrush obligate but this relationship and other aspects of this species have been little studied. Previous studies include an analysis of population dynamics (Wilde 1978) and a study of reproduction (Fisher 1979) conducted on the Idaho National Engineering and Environmental Laboratory (INEEL), and one on rabbit diet (Green 1978, Green and Flinders 1980) conducted on the U.S. Sheep Experimental Station near Dubois, Idaho. Wilde (1978) documented that pygmy rabbits dig their burrows in definable clusters of varying numbers of burrows (burrow sites), presumably in patches of desirable habitat. However, neither INEEL study addressed the distribution of rabbits on the INEEL nor the habitat characteristics associated with rabbit "burrowing sites." Green and Flinders (1980) collected limited data on vegetation at six burrowing sites. Based on their limited sample, they found that pygmy rabbits preferred areas with greater woody cover and shrub height than randomly selected areas. However, this information was not used to develop any predictive capability as to where pygmy rabbit colonies might be found. There are additional questions about home range size and habitat use that remain unanswered. The importance of burrows and particular vegetation characteristics associated with burrows has been demonstrated. However, the significance of additional habitat components within non-burrow areas of the home range is unclear.

Currently, the western U.S. is experiencing annual losses of native sagebrush habitat. This continual loss of appropriate habitat for pygmy rabbits has resulted in an overall reduction of their populations. This reduction has led to its classification as a "species of special concern." Under this classification, pygmy

\footnotetext{
${ }^{8}$ Department of Biological Sciences, Campus Box 8007, Idaho State University, Pocatello, ID 83209.
} 
rabbits should receive special consideration in projects that must comply with National Environmental Policy Act (NEPA) regulations. The INEEL represents one of the last large protected areas for pygmy rabbits and its operations are governed by NEPA regulations, specifically those related to Section 7 consultations with U.S. Fish and Wildlife Service personnel. Providing mitigation for pygmy rabbits could have major, costly implications for current operations and future development at the INEEL. To comply with NEPA regulations, INEEL personnel need information on the pygmy rabbit's distribution, abundance, and habitat needs. Access to this information will enable rapid and inexpensive assessment of the potential suitability for pygmy rabbits of areas considered for development. Such an assessment of habitat is lacking at the INEEL. This current study was designed to provide the information necessary for compliance and avoid possible costly delays in meeting NEPA regulations regarding this species.

Additionally, this study will provide the information necessary to avoid destruction of pygmy rabbit habitat in future developments.

The general decline in pygmy rabbit numbers could also be of concern to Native Americans who traditionally hunted this species. Its preservation could be viewed as important to maintaining their traditional values and ways. Consequently, any INEEL activities that might impact pygmy rabbit distribution and abundance could come under the scrutiny of tribal leaders. INEEL personnel could address any concerns raised if data on abundance, distribution, and habitat and a method of assessing the impact of INEEL site development were available. Ultimately, by learning more about this unique species, the INEEL can assist in the preservation of biodiversity in the Great Basin desert ecosystem.

\section{Objectives}

This research is designed to assess pygmy rabbit distribution, abundance, and habitat needs on the INEEL, and develop a habitat suitability index (HSI) as a valid predictor of possible pygmy rabbit occurrence at proposed development sites. Specific objectives of the study are to:

- Locate at least 10 pygmy rabbit burrowing sites.

- Capture and fit 10 rabbits with radio collars.

- Identify foraging areas of the radio-collared animals by locating them periodically over 24-hour periods.

- Assess habitat characteristics of burrowing and foraging areas.

Measured habitat characteristics will include density and height of tall and short shrubs, topographic characteristics, and soil texture.

- Calculate a Habitat Suitability Index (HSI).

We will calculate the index as the first principal component of vegetation height, soil composition, and topographic complexity.

- Combine habitat information with Geographical Information System (GIS) vegetation files of the INEEL to develop a predictive index of possible pygmy rabbit locations.

- Use the HSI to predict all possible sites of pygmy rabbit locations on the INEEL.

- Determine the reliability of the HSI.

We will select 30 sites predicted to have rabbits and determine whether they are 
actually present at the site.

- Based on the above analyses, produce a map of likely rabbit locations on the INEEL.

\section{PROJECT ACCOMPLISHMENTS}

During the calendar year 1996, the following were accomplished:

- The survey of all INEEL roads for presence of pygmy rabbits was completed.

- A map of potential pygmy rabbit habitat on the INEEL was created.

- Thirty random predicted sites and 10 non-predicted sites were selected and sampled.

- Calculation of an HSI was initiated.

- A second study area in the northeastern portion of the site (UTM 4847517 365412) was established for conducting radiotelemetry. Three females and one male from this site were trapped and radio-collared during the summer.

- Approximately 100 hours of telemetry were conducted at the new site, with at least two and up to three individuals tracked simultaneously. Approximately 50 hours of activity pulse data were collected, with either one or two rabbits observed simultaneously.

- Preliminary analysis of individual pygmy rabbit home ranges was conducted.

- Point quarter sampling was completed at six additional burrow sites. Vegetation and topographic features data and soil samples were collected at all 11 burrow sites. This sampling was also completed at all random predicted and non-predicted sites.

- Characterization of short shrub $(<50 \mathrm{~cm})$ and tall shrub $(>=50 \mathrm{~cm}$ ) density and height at 11 burrow sites was completed.

- Approximately 500 camera trap nights were conducted.

- Activity pulse data collected during radiotelemetry sessions were analyzed.

\section{IMPORTANT RESULTS}

Analysis of location data from one subject male and one subject female suggests that males utilize a larger home range area than females. Pygmy rabbits do not appear to use their home range uniformly; rather, there are areas of high, medium, and low use. The distribution of movements are clumped in the burrow area, along with approximately 10 additional $30 \mathrm{~m}^{2}$ cells within the home range. The remainder of home range appears to receive low use.

Within $40 \mathrm{~m} \times 40 \mathrm{~m}$ point-quarter sampling grids around the burrow sites, trends in vegetation were observed. Height of tall shrubs was significantly higher in adjacent sampling cells than in peripheral cells $(\mathrm{P}=0.018$ ) (Fig. 14). No trends were observed for height of short shrubs. Short shrub density was significantly higher in peripheral sampling cells (approximately $15 \mathrm{~m}$ from the burrow entrance) than in cells adjacent to the burrow ( $\mathrm{P}=0.001)$ (Fig. 15). No trends were observed for tall shrub density. These sampling grids will be compared to those of randomly-selected low, medium, and high use areas.

Daily summer activity peaks were observed at sunrise and early morning, between approximately 6 am and $8 \mathrm{am}$, and at sunset, between 8 p.m. and 10 p.m. (Fig. 16, Fig. 17). These preliminary data suggest that pygmy rabbits are not entirely crepuscular; they persist in a relatively high 


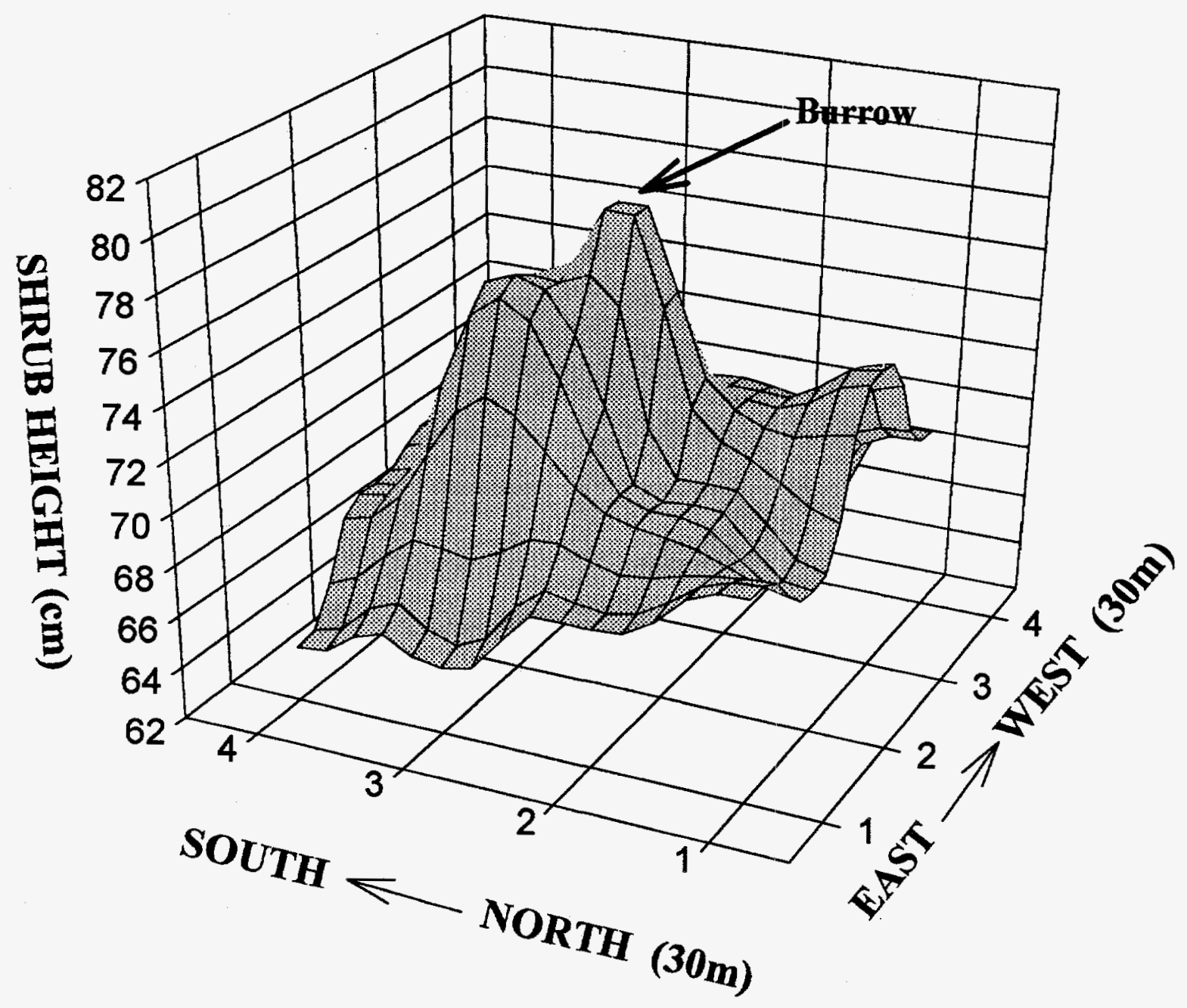

Fig. 14. Mean "tall" shrub height of five point quarter sample grids around burrow sites. 


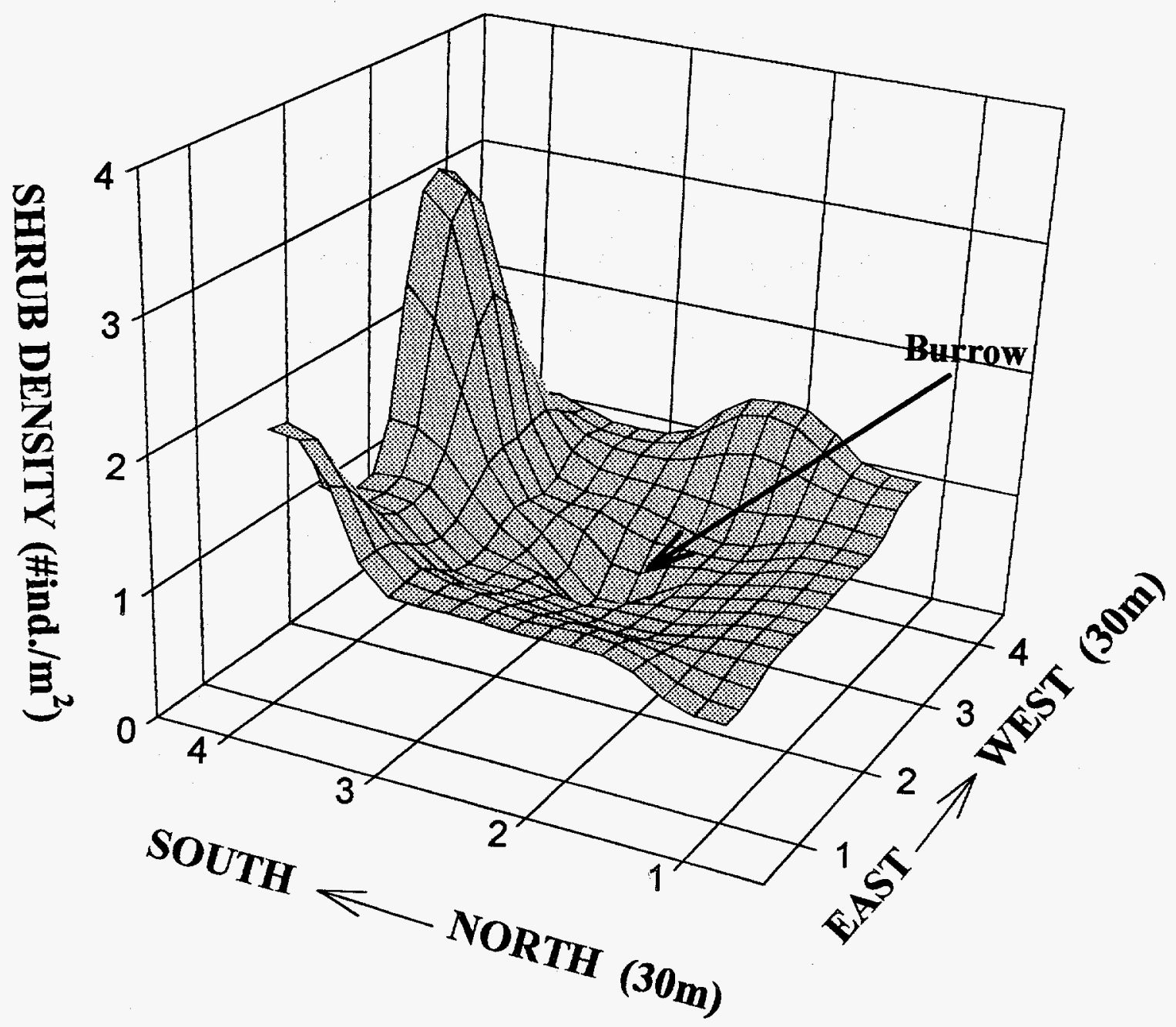

Fig. 15. Mean "short" shrub density of five point quarter sample grids around burrow sites. 


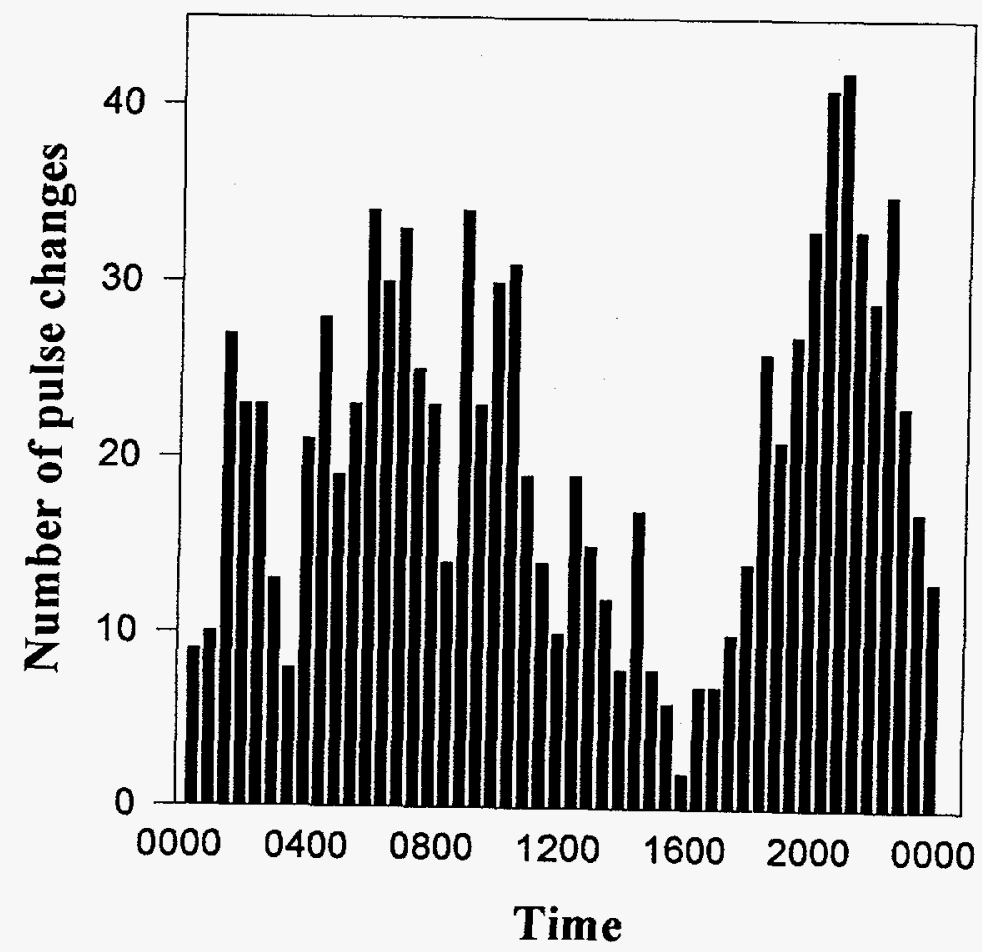

Fig. 16. Daily activity patterns of a male pygmy rabbit, based on the average number of pulse changes for every half hour interval within a 24-hour block Analysis was based on five 24-hour blocks.

level of activity throughout the morning hours.

\section{PRODUCTS}

One poster presentation was presented at a scientific meeting during 1996:

- Heady, Laura T., Kate I. Gabler, and John W. Laundré. 1996. Habitat and behavior assessment of an endemic rabbit species (Brachylagus idahoensis) in southeastern
Idaho. Society for Conservation Biology and Ecological Society of America Joint Annual Meetings, Rhode Island.

\section{Literature Cited}

Chapman, J. A. 1990. Conservation action needed for rabbits, hares, and pikas. Pages 1-5 in J. A. Chapman and J. E. C. Flux, eds. Rabbits, hares, and pikas: status survey and conservation action plan. International Union for Conservation of Nature and Natural Resources, Gland, Switzerland. 


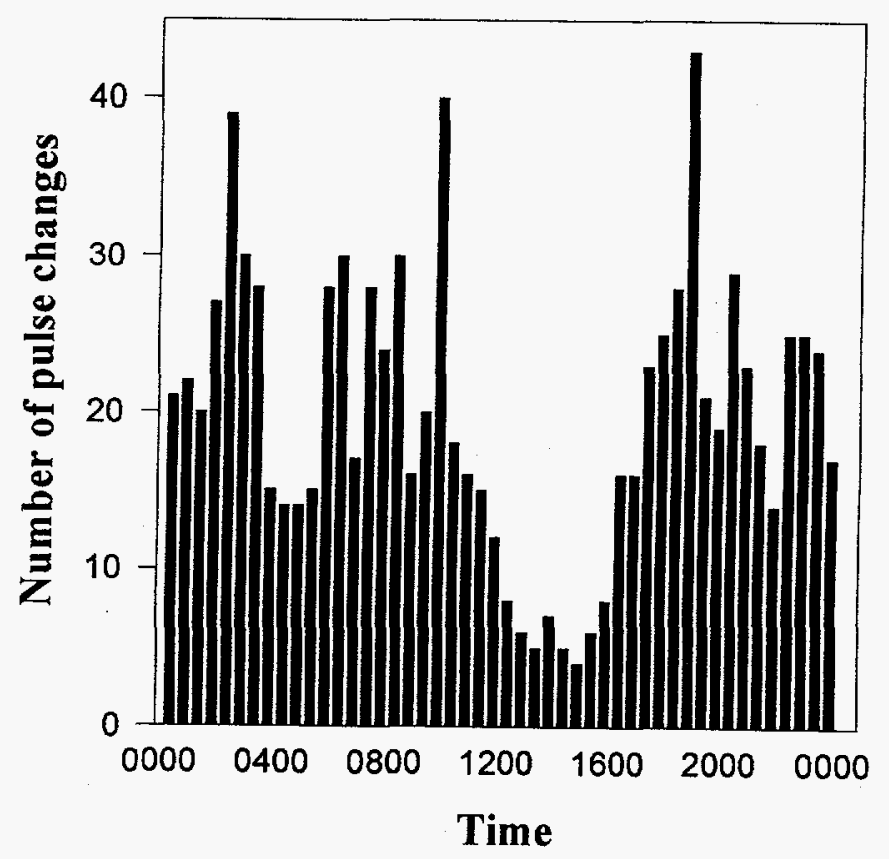

Fig. 17. Daily activity patterns of a female pygmy rabbit, based on the average number of pulse changes for every half hour interval within a 24-hour block Analysis was based on five 24-hour blocks.

Dobler, F. C. and K. R. Dixon. 1990. The pygmy rabbit. Pages 111-115 in J. A. Chapman and J. E. C. Flux, eds. Rabbits, hares and pikas: status survey and conservation action plan. International Union for Conservation of Nature and Natural Resources, Gland, Switzerland.

Fisher, J. S. 1979. Reproduction in the pygmy rabbit in southeastern Idaho. Master's thesis, Idaho State University, Pocatello. $32 \mathrm{pp}$.

Green, J. S. 1978. Pygmy rabbit and coyote investigations in southeastern Idaho. Ph. D. dissertation, Brigham Young
University, Provo, Utah. 88 pp.

Green, J. S. and J. T. Flinders. 1980. Habitat and dietary relationships of the pygmy rabbit. Journal of Range Management 33:136-142.

Washington Department of Fish and Wildlife. 1995. Washington state recovery plan for the pygmy rabbit. Wildlife Management Program, Washington Department of Fish and Wildlife, Olympia. 73 pp.

Wilde, D.B. 1978. A population analysis of the pygmy rabbit (Sylvilagus idahoensis) on the INEL site. Ph. D. dissertation, Idaho State University, Pocatello. $172 \mathrm{pp}$. 


\title{
HEAVY METALS IN SMALL MAMMAL POPULATIONS AT THE IDAHO NATIONAL ENGINEERING AND ENVIRONMENTAL LABORATORY
}

\author{
Bruce D. Eshelman ${ }^{9}$
}

\begin{abstract}
The objective of this research was to identify contamination levels of small mammal populations exposed to heavy metals in the environment. Inductively coupled plasma techniques were used to evaluate the level of contamination in soil, plant food species, and three species of small mammals: deer mouse (Peromyscus maniculatus), Ord's kangaroo rat (Dipodomys ordii), and least chipmunk (Tamias minimus). Additionally, deer mice were maintained in a laboratory colony to determine the effects of dietary contamination (lead) on the long-term health and reproduction these mice. Preliminary data indicated detectable levels of lead, chromium, and cadmium in populations of small mammals on control and experimental grids. Soils from the experimental grid had significantly higher concentrations of lead and chromium than the control grid. Laboratory tests suggest deer mice can not only detect lead in their diet, but discriminate between different levels of lead.
\end{abstract}

Keywords: Cadmium, chromium, heavy metals, heavy metal contamination, lead, small mammals

\section{JUSTIFICATION}

This research addresses the general mission of the DOE Environmental Restoration Program by assessing the extent of harmful substances (heavy metals), identifying contamination levels in various environmental media, and measuring impacts on natural populations of small mammals.

Many areas of the United States are currently contaminated with heavy metals. High levels of contamination are often the result of earlier land use practices (Elfving et al. 1979), industrialization (Fleming et al. 1979), or even areas of heavy automobile traffic (Goldsmith et al. 1976, Goldsmith and Scanlon 1977). Contamination levels and areas of contamination may be increasing on a national level. There is a lack of information on the effects of heavy metal exposure on the dynamics of natural populations of animals (McBee and Bickham 1990). This research focuses on the availability and toxicity of chromium and lead to populations of small mammals resident on a contaminated area of the INEEL. These elements are known to be toxic to small mammals and are found in abnormally high concentrations in some soils at the INEEL (Eshelman unpublished data, this study). Small mammals fit the criteria for use as biomonitors suggested by Jenkins (1981): common, geographically widespread, and easily collected. These animals also occur naturally on both contaminated and uncontaminated sites and are also large enough to provide multiple tissue samples for analysis. Additionally, the three species of focal animals each consumes plant material yet each feeds on different portions and species of plants. Because of their different feeding habits, some species of small mammals may be more at risk than others under the same general level of contamination in the environment.

Heavy metals can become concentrated in plants growing on contaminated sites (Arthur et al. 1992) which can then be used as food by local populations of small mammals. Use of food sources contaminated with heavy metals can cause death of individuals (Mason et al, 1986, Fleming et al. 1979) and as a result, may severely impact local populations and animals higher up the food chain.

An experimental grid for live-trapping and long term monitoring of populations has been established in an area of known contamination. A control grid is located approximately $700 \mathrm{~m}$ away in a natural

${ }^{9}$ Department of Biological Sciences, Idaho State University, Pocatello, Idaho 8:209-8007

Present Address: Department of Biological Sciences, University of Wisconsin-Whitewater, Whitewater, WI 53190 
vegetation community on the Idaho National Engineering and Environmental Laboratory (INEEL). Preliminary soil analyses indicated levels of lead and chromium were significantly higher within the experimental grid than within the control grid. Both grids supported populations of deer mice, Ord's kangaroo rat, and least chipmunk. Animals on the experimental grid were exposed to levels of lead in the surface soil as high as 521 parts per million ( $\mathrm{ppm}$ ) and levels of chromium as high as $52 \mathrm{ppm}$. There is currently a great need for information on population-level effects of environmental contamination on naturally occurring populations (McBee and Bickham 1990). Results from the this research will begin to fill the recognized gap in our knowledge of natural system responses to environmental contamination.

\section{Objective}

The objective of this study is to test hypotheses dealing with the effects of in situ concentrations of heavy metals resident populations of small mammals. The three near-term null hypotheses regarding field levels of heavy metals at the INEEL were:

- There is no difference in heavy metal concentrations (lead, chromium, or cadmium) in the soils of the experimental or control grids.

- There is no difference in heavy metal concentrations in the plants that occupy the grids.

- There is no difference in heavy metal concentrations found in small mammals that reside on the grids.

The long-term set of null hypotheses associated with this study address the fitness of individuals exposed to in situ levels of heavy metals on the control and experimental grids. This consists of a set of laboratory experiments testing the hypotheses:
- The growth rate of animals raised on a diet containing in heavy metals and a standard diet is the same.

- The reproductive parameters of animals raised on a diet containing heavy metals and a standard diet are equal.

Young mammals can receive contaminants via the mother's milk and often accumulate heavy metals faster than adults (Bacher 1985, Fleming et al. 1979). This may influence life expectancy or reproduction of contaminated individuals and therefore influence the dynamics of exposed populations.

Experiments addressing these hypotheses are currently being performed in the laboratory.

\section{PROJECT ACCOMPLISHMENTS}

- During 1996 we initiated breeding and growth experiments to determine the effects of long term exposure to lead in the diet on deer mice.

Deer mice were obtained from the Peromyscus stock center and placed in the animal care facility at Idaho State University. A total of five breeding pairs for each of three diets was used to establish the colony. The animals were placed in one of three dietary groups. Animals in the groups were fed an ad lib diet containing one of the following concentrations of lead acetate: $0 \mathrm{ppm}, 35$ $\mathrm{ppm}$, or $70 \mathrm{ppm}$. Animals were maintained on a 15:9 hour light:dark cycle to encourage breeding. Breeding of each of the groups has proceeded throughout the year. We are currently in the fourth generation of these animals. During the year the animals were successfully transferred to University of Wisconsin-Whitewater facilities where the PI has taken a tenure track position in the Department of Biological Sciences. These experimental animals are currently awaiting completion of the breeding series before tissue analysis by ICP will be performed on individuals from all generations. 
- A series of dietary selection experiments were performed to determine whether deer mice could differentiate among diets containing quantities of lead or an uncontaminated diet.

Twenty-four deer mice were randomly assigned to a diet preference trial. The trials consisted of the mice being given a choice of lab chow contaminated with different levels of lead $(0,30,70 \mathrm{ppm})$. Trial 1 offered animals a choice of control $(0 \mathrm{ppm})$ and 35 ppm lead-contaminated chow; Trial 2 presented control $(0 \mathrm{ppm})$ and $70 \mathrm{ppm}$ leadcontaminated chow; Trial 3 offered choices between chow contaminated at either 35 or 70 ppm.

The amount of each food consumed was recorded every third day for approximately 5 weeks.

- A total of 138 plant samples were collected from the experimental and control grids in 1995. Portions of these samples were analyzed in 1996.

These samples will increase the sample size necessary for a more complete comparison of plant tissues between the control and experimental groups.

- Animals that had been captured in the field were sacrificed and analyzed for heavy metal content of body tissues.

Deer mice, Ord's kangaroo rats, and least chipmunks were collected for analysis. Bone (the body's reservoir for lead) and liver tissue were collected from animals that were residents of either the control or experimental grid.

\section{IMPORTANT RESULTS}

Although final statistical analyses have not been completed, the data indicate little to no preference in Diet Preference Trial 1. In Trial
2, some of the animals showed a cyclical pattern. Animals would switch their preference for either the control or $70 \mathrm{ppm}$ chow. This suggested the mice may have preferred the taste of the $70 \mathrm{ppm}$ chow, but an excessive amount may have caused some symptoms of lead poisoning, with a concomitant switch to the control chow.

A follow-up to these results would be to take blood samples from the animals and monitor the lead level in the blood. If periods of preferentially eating the control diet correspond to high levels of lead in the blood, then this would substantiate the earlier suggestion. In treatment 3, the mice appear, almost without exception, to prefer the 35 ppm food. This suggests that the animals prefer the taste of the chow contaminated with lead, but a diet of mostly $70 \mathrm{ppm}$ may be too much. Final analyses of these experiments is currently in progress.

Highest levels of contamination in plant tissues were found in the leaves of plants from the experimental grid, especially the area associated with the drainage ditch. Highest level of lead was found to be 49.4 ppm in the leaves of the tansy mustard (Descurainia pinnata). Further analysis of this data is proceeding and will relate plant location to the level of contamination in the soil.

An analysis of variance found no difference in contamination level of bone between small mammals collected the experimental or: control grid. However, lead and chromium were significantly higher in bone tissue of the deer mouse ( $P$. maniculatus) than the other rodent species. Cadmium levels in the liver did not differ between grids but were significantly higher in liver tissues of chipmunks than the other rodents.

\section{PRODUCTS}

Three presentations were given during 1996: 
- Eshelman, B. D. 1996. The ups and downs of nutritional ecology. Invited Seminar, Department of Biological Sciences, University of Wisconsin-Whitewater, WI 53190. February 1996.

- Eshelman, B.D., C. S. Sonnemann. 1996. Heavy metals in small mammal habitats and populations at the Idaho National Engineering Laboratory. Annual meeting of the American Society of Mammalogists, Grand Forks, ND. June 1996.

- Sonnemann, C. S., B.D. Eshelman. 1996. Avoidance of lead contaminated food sources by Peromyscus maniculatus. Annual meeting of the American Society of Mammalogists, Grand Forks, ND. June 1996.

\section{LITERATURE CITED}

Arthur, M. A., G. Rubin, P. B. Woodbury, R. E. Schneider, and L. H. Weinstein. 1992. Uptake and accumulation of selenium by terrestrial plants growing on a coal fly ash landfill. Part 2. Forage and root crops. Environmental Toxicology and Chemistry 11:1289-1299.

Bacher, G. J. 1985. Mercury concentrations in the Australian fur seal Arctocephalus pusillus from SE Australian waters.

Bulletin of Environmental Contamination and Toxicology 35:490-495.

Brown, J. S. 1994. Foraging theory, patch use, and the structure of a Negev desert granivore community. Ecology $75: 2286-2300$.
Elfving, D. C., R. A. Stehn, I. S. Pakkala, and D. J. Lisk. 1979. Arsenic content of mammals indigenous to old orchard soils. Bulletin of Environmental Contamination and Toxicology 21:62-64.

Fleming, W. J., W. H. Gutenmann, D. J. Lisk. 1979. Selenium in tissues of woodchucks inhabiting fly ash landfills. Bulletin of Environmental Contamination and Toxicology 21:1-3.

Goldsmith, C. D., Jr., P. F. Scanlon, and W. R. Pirie. 1976. Lead concentrations in soil and vegetation associated with highways of different traffic densities. Bulletin of Environmental Contamination and Toxicology 16:66-70.

Goldsmith, C. D., Jr. and P. F. Scanlon. 1977. Lead levels in small mammals and selected invertebrates associated with highways of different traffic densities. Bulletin of Environmental Contamination and Toxicology 17:311-316.

Jenkins, D. W. 1981. Biological monitoring of toxic trace elements. Pages 1-10 in U.S. EPA-600/S3-80-090.

Mason, C. F., N. I. Last, and S. M. MacDonald. 1986. Mercury, cadmium and lead in British Otters. Bulletin of Environmental Contamination and Toxicology 37:844-849.

McBee, K. and J. W. Bickham. 1990. Mammals as bioindicators of environmental toxicity. Pages 37-88 in $\mathrm{H}$. H. Genoways ed., Current Mammalogy Vol. 2. Plenum Publisher.

Valone, T. J. and J. S. Brown. 1989. Measuring patch assessment abilities of desert granivores. Ecology 70:1800-1810. 


\title{
LONG-TERM VEGETATION DYNAMICS AT THE IDAHO NATIONAL ENGINEERING AND ENVIRONMENTAL LABORATORY
}

\author{
Jay E. Anderson ${ }^{10}$
}

\begin{abstract}
The Idaho National Engineering and Environmental Laboratory (INEEL) is the largest of the few protected areas of sagebrush steppe, the most extensive vegetation type in the northern Intermountain West. The area supports extensive, healthy populations of the indigenous shrubs, grasses, and forbs found in cold desert communities of the region. Many of these species have been extirpated from other areas by livestock grazing. Thus, the INEEL provides a unique opportunity to study vegetation dynamics under relatively natural conditions. Long-term vegetation studies at the INEEL were initiated in 1950, and data have been collected at least every 10 years from 92 permanent plots along perpendicular lines that transect the entire site. Most recently, data were collected during the summer of 1995, a record precipitation year. The data show that vegetal structure and composition on the INEEL are dynamic and tend to follow climatic patterns. Over the 45 years of record, cover of big sagebrush (Artemisia tridentata), the dominant shrub, has declined relative to that of other shrubs and perennial grasses. In years when perennial grass cover was highest, there was a negative correlation between shrub and grass cover, indicating that competitive interactions are important in determining species abundances. Species richness per plot has generally increased over the 45-year period, and plant cover per plot was correlated with species richness in the majority of census years. This supports the hypothesis that productivity is positively correlated with species richness.
\end{abstract}

Keywords: Microbiotic crusts, long-term vegetation transects, sagebrush steppe, vegetation dynamics

\section{JUSTIFICATION}

The Idaho National Engineering and Environmental Laboratory (INEEL) occupies $2,315 \mathrm{~km}^{2}$ of the temperate sagebrush-steppe region (West 1983) on the upper Snake River Plain in southeastern Idaho. The central portion of the INEEL has been protected from livestock grazing and other human caused disturbances since 1950. Extensive, healthy populations of most of the indigenous shrubs and grasses found in cold desert communities of the region occur at the INEEL (Anderson and Holte 1981, Anderson et al. 1996). Of particular significance is the diversity of native forbs (Anderson et al. 1996), which have been extirpated from many areas by livestock grazing. Thus, the INEEL is an important reservoir of the biodiversity of sagebrush steppe ecosystems (Anderson et al. 1996).

The existence of relatively pristine cold-desert communities coupled with a vegetation database that spans 4.5 decades provides an unparalleled opportunity to study the vegetation dynamics of sagebrush steppe.
Vegetation studies were initiated at the INEEL in 1950 with the establishment of 94 permanent sample plots at $1.6-\mathrm{km}$ intervals along two perpendicular lines that transect the entire INEEL from the southwest to the northeast and from the southeast to the northwest (Anderson et al. 1978). Two plots were destroyed before 1957. Data from the remaining 92 plots were collected in 1957 , 1965, 1975, 1985 and 1995. Additional data from a 35-plot subsample were collected in 1978, 1983, and 1990. These data have been the basis of numerous publications and reports (Harniss and West 1973a, b, Anderson et al. 1978, Anderson and Holte 1981, Anderson 1986, Anderson and Inouye 1988), which provide a critical baseline for future studies of long-term vegetation dynamics. The data show that the vegetation at the INEEL is anything but static, even in the absence of major disturbances such as grazing or fire. For example, two-fold changes in shrub cover and five-fold changes in perennial grass cover occurred between 1950 and 1985 (Anderson and Inouye 1988). These rather dramatic fluctuations appear to be correlated

${ }^{10}$ Department of Biological Sciences, Idaho State University, Pocatello, Idaho 83209-8007 
with long-term climatic patterns. The average richness of perennial grasses and forbs per plot has increased since the area was first protected. The density of perennial forbs appears to track variation in precipitation more closely than does density of perennial grasses or shrubs. These patterns could not have been detected without this long-term data base.

This long-term vegetation monitoring also provides data necessary for implementing, or complying with, the National Environmental Policy Act, Endangered Species Act, Federal Noxious Weed Act, and agreements with the Bureau of Land Management and the Shoshone-Bannock Tribes.

\section{Objectives}

The major objectives of this project are to document and analyze changes in vegetation at the INEEL that have taken place over the past 45 years and to relate such changes to variation in climate or other factors such as invasions by exotic species (e.g., cheatgrass, Bromus tectorum). Specific objectives for FY 1996 were to:

- update the long-term vegetation database for the INEEL

- analyze the 1995 vegetation data.

- prepare a manuscript on long-term vegetation dynamics at the INEEL

\section{PROJECT ACCOMPLISHMENTS}

In calendar year 1996 we:

- Completed computer entry of all long-term vegetation data collected in 1995 . Thus, the long-term vegetation database has been updated.
- Analyzed the 1995 vegetation data in the context of the entire database.

Considerable time was invested in attempting to track trajectories of vegetation change using ordination techniques. To date, this effort has not yielded satisfactory results. All of the other anticipated analyses have been completed.

- Submitted a short manuscript on the relationship between species diversity and total vegetative cover to Ecology. The manuscript was rejected with the recommendation that the findings be incorporated into a more comprehensive treatment.

- Began preparing a comprehensive manuscript on long-term vegetation dynamics at the INEEL.

\section{IMPORTANT RESULTS}

Over the 45-year period of record, cover of perennial grasses and shrubs was correlated with the amount of precipitation received 2 to 5 years prior to the year of the census. The response of shrubs differed from that of perennial grasses. Cover of grasses was best correlated with a 4-year lag in precipitation, whereas the lag time was shorter, 2 - 3 years, for shrubs. We postulate that these patterns reflect differences in life histories, rates of growth, and patterns of recruitment among the different species.

The proportion of total plant cover contributed by big sagebrush (Artemisia tridentata) has declined significantly since 1950 (Fig. 18, Fig. 18). This change has been accompanied by modest increases in the relative cover of green rabbitbrush (Chrysothamnus viscidiflorus) and perennial grasses. 


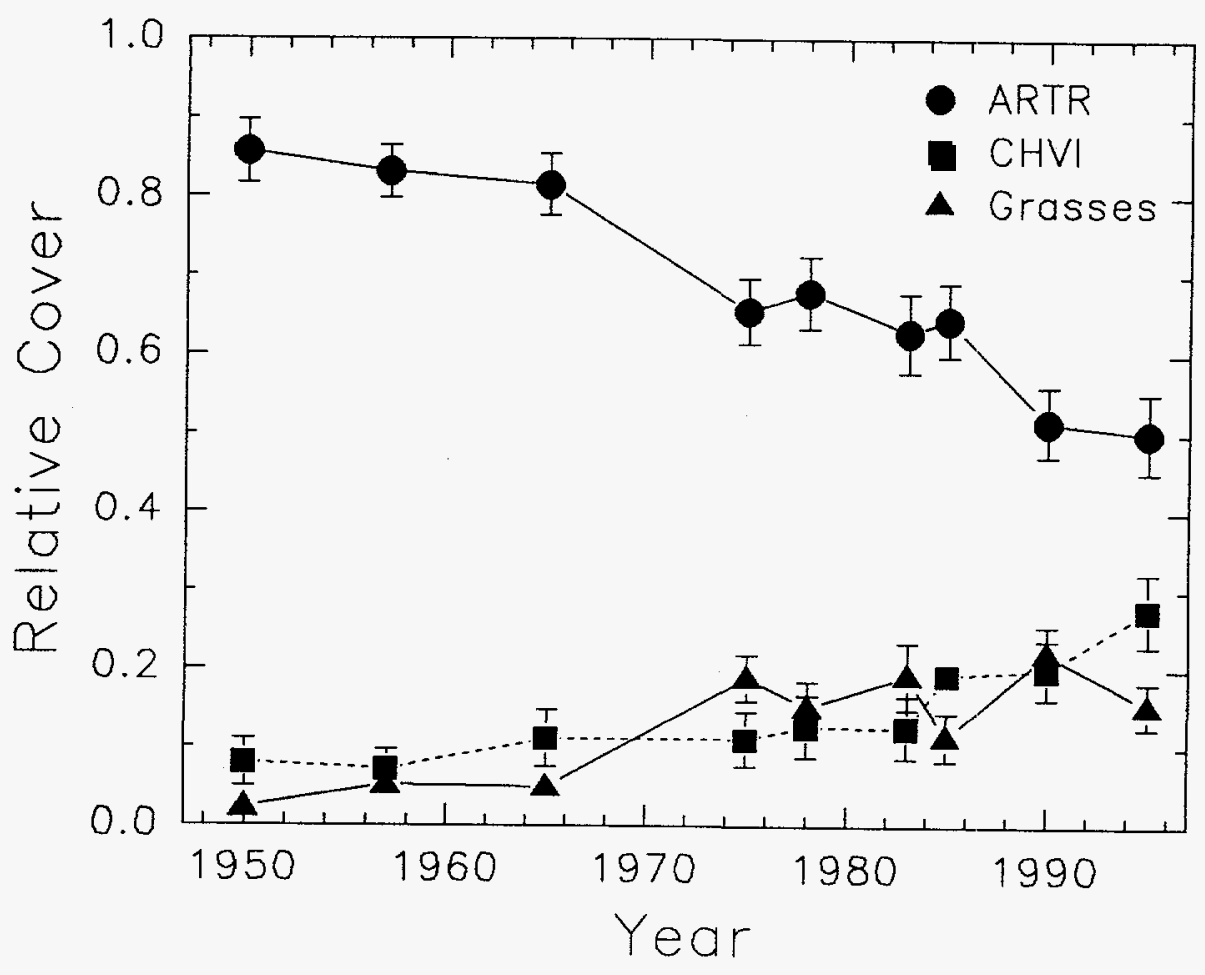

Fig. 18. Relative cover of big sagebrush (Artemisia tridentata; ARTR), green rabbitbrush (Chrysothamnus viscidiflorus), and perennial grasses on 35 permanent vegetation plots at the Idaho National Engineering and Environmental Laboratory.

We found strong evidence suggesting that biotic interactions such as competition among species may influence species abundances. Cover of perennial grasses was negatively correlated with that of shrubs in those census years in which perennial grass cover was highest (Fig. 19), indicating the increase in perennial grass cover following wetter years was constrained in areas having high shrub cover.

The average number of species per sample plot (species richness) of both shrubs and perennial grasses has increased over the 45 years of record. In 6 of 9 census years, cover of perennial grasses was positively correlated with species richness (Fig. 20). Similarly, shrub cover and species richness were positively correlated in 8 of 9 years (Fig. 21). These results are consistent with recently described patterns from grasslands in Minnesota (Tilman 1996, Tilman et al. 1996), and they support the hypothesis that there is an important mechanistic link between species diversity of an ecosystem and its productivity.

\section{PRODUCTS}

- Data and analyses from this project contributed to the recently published book: 

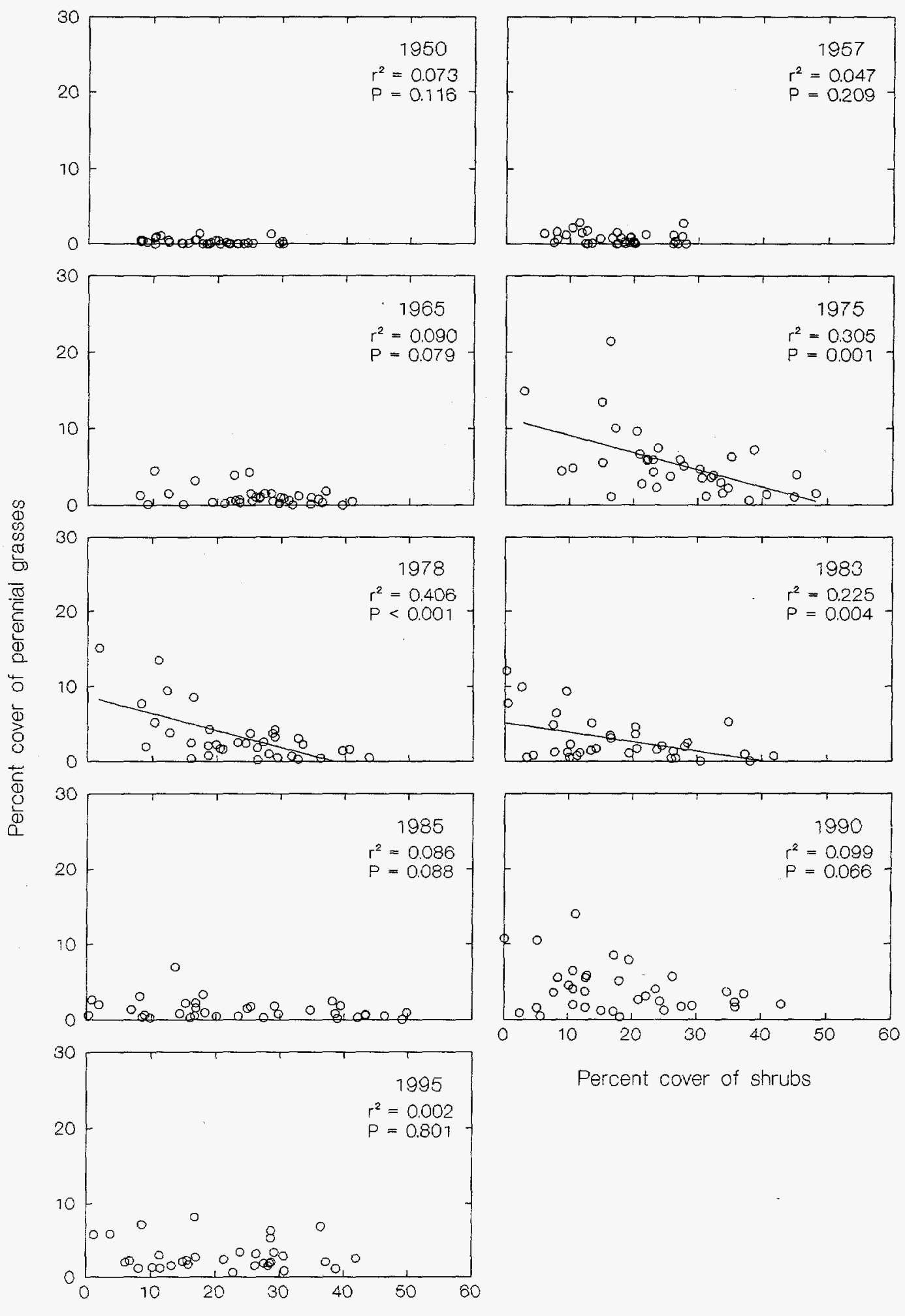

Percent cover of shrubs

Percent cover of shrubs

Fig. 19. Mean cover of perennial grasses plotted against mean cover of shrubs for 35 permanent plots at the Idaho National Engineering and Environmental Laboratory. Regression lines are drawn for those years in which there was a significant $(\mathrm{P}<0.05)$ linear relationship between perennial grass and shrub cover. 

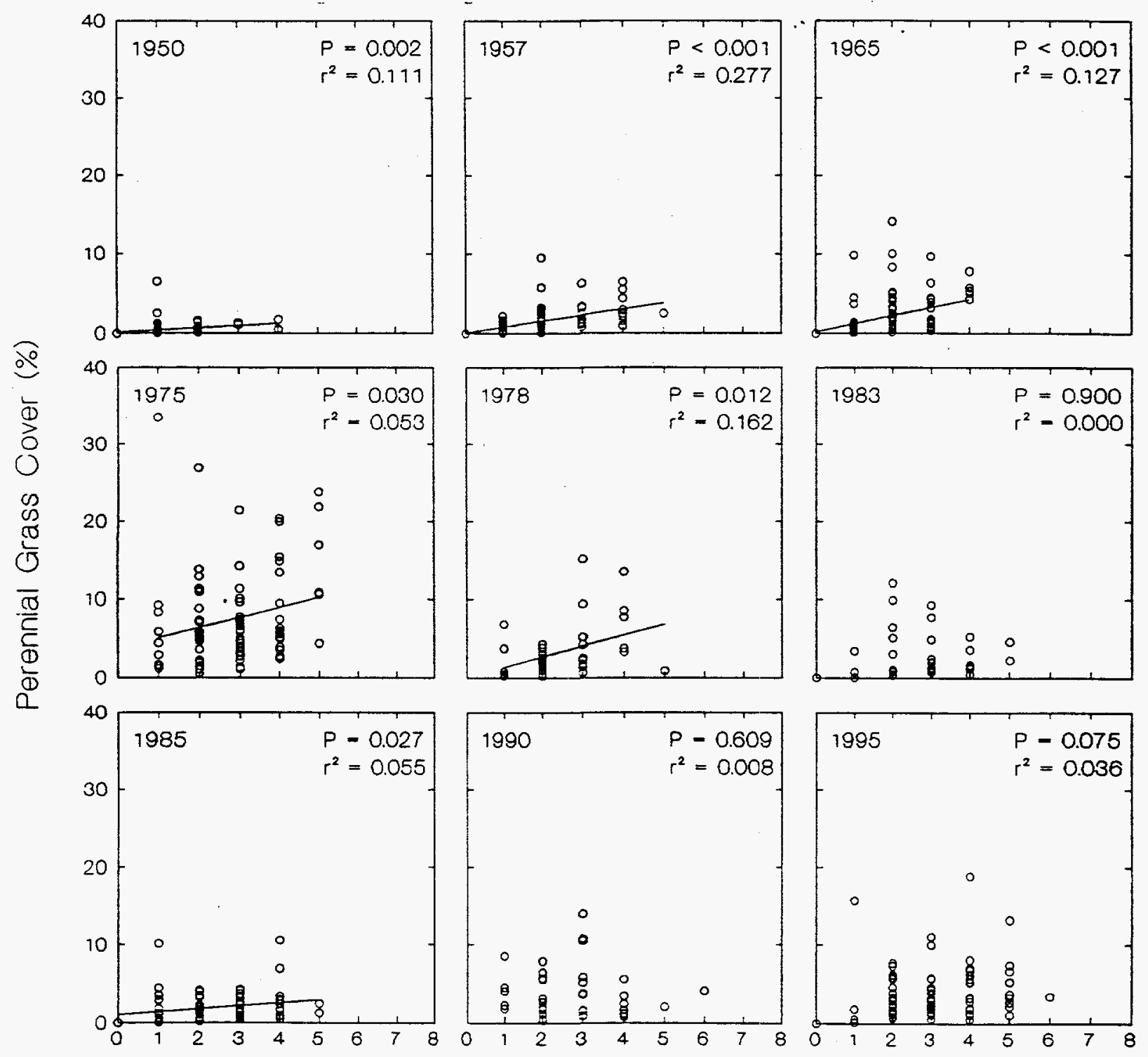

Perennial Grass Species Richness

Fig. 20. Perennial grass cover plotted against perennial grass species richness for nine census years on permanent plots at the Idaho National Engineering and Environmental Laboratory. Each point represents one plot. 

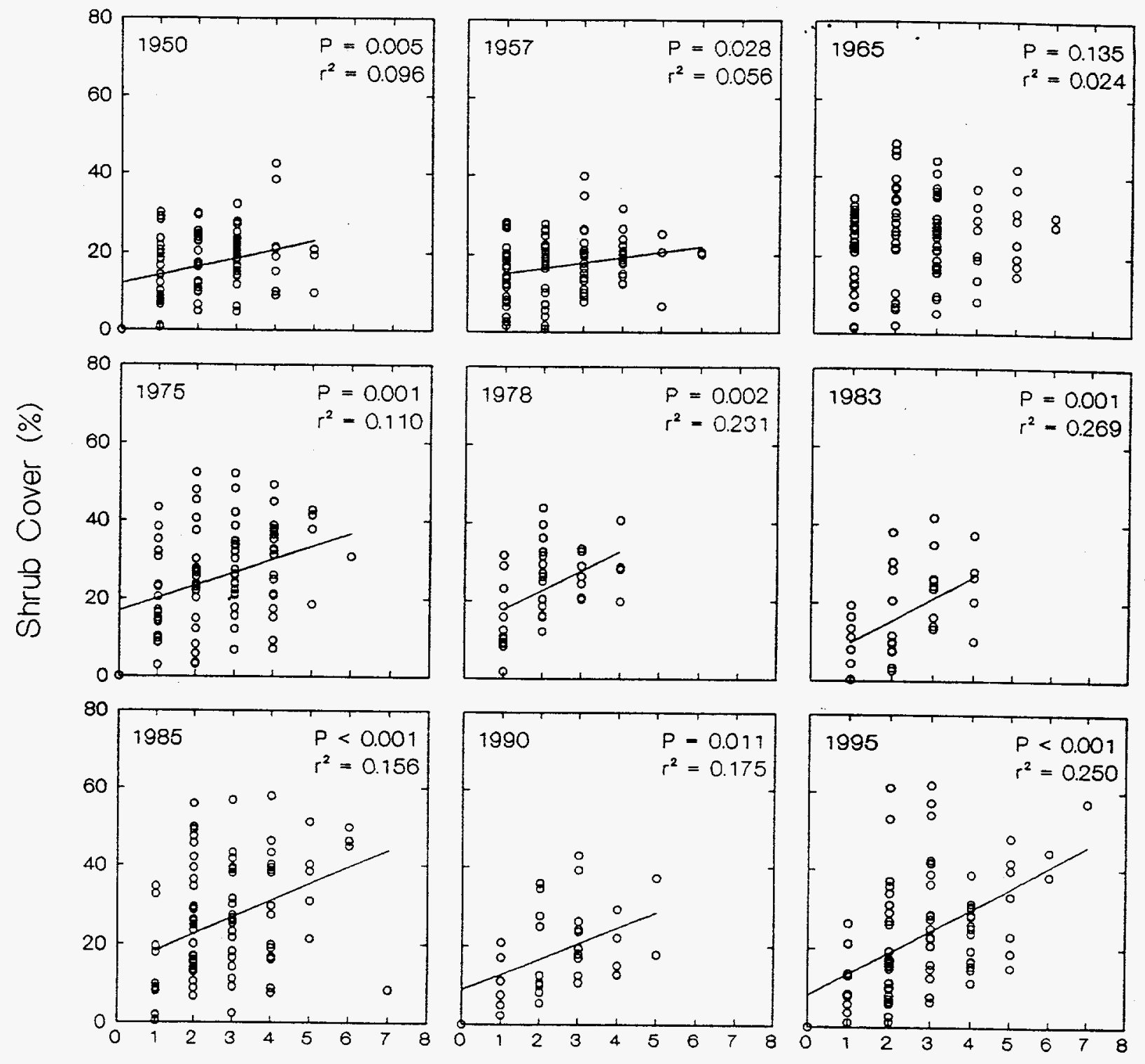

Shrub Species Richness

Fig. 21. Shrub cover plotted against shrub species richness for nine census years on permanent plots at the Idaho National Engineering and Environmental Laboratory. Each point represents one plot. Regression lines are drawn for those years in which there was a significant $(\mathrm{P}<0.05)$ linear relationship between cover and species richness. 
Anderson, J. E., K. T. Ruppel, J. M. Glennon, K. E. Holte, and R. C. Rope. 1996. Plant communities, ethnoecology, and flora of the Idaho National Engineering Laboratory. ESRF-005, Environmental Science and Research Foundation, Idaho Falls, Idaho. 111 pp.

- Results from these and other vegetation and plant ecophysiological studies at the INEEL contributed significantly to case studies on three important cold-desert species, Great Basin wildrye (Leymus cinereus), big sagebrush (Artemisia tridentata), and cheatgrass (Bromus tectorum) which appeared in the following book:

Smith, S. D., R. K. Monson, and J. E. Anderson. 1997. Physiological ecology of North American Desert Plants. Springer-Verlag, Berlin. 286 pp.

- Data from this project contributed to a poster presentation at the 1996 Annual Meeting of the Ecological Society of America:

Rasmuson, K. E. and J. E. Anderson. 1996. Root growth and water relations of Bromus tectorum in response to drying soil surfaces. Annual Meeting, Ecological Society of America, Providence, RI.

- Data from the long-term vegetation database and previous funding from this project made significant contributions to a student dissertation.

Rasmuson, K. E. 1996. Population and individual responses of Bromus tectorum to environmental stresses: a study of factors that may limit its distribution in cold-desert habitats. Ph.D. Dissertation, Idaho State University, Pocatello.

\section{LITERATURE CITED}

Anderson, J. E. 1986. Development and structure of sagebrush steppe plant communities. Pages 10-12 in P. J. Joss, P. W. Lynch and O. B. Williams, eds., Rangelands: A resource under siege Proceedings of the Second International Rangeland Congress. Australian Academy of Science, Canberra.

Anderson, J. E. and K. E. Holte. 1981. Vegetation development over 25 years without grazing on sagebrush-dominated rangeland in southeastern Idaho. Journal of Range Management 34:25-29.

Anderson, J. E. and R. Inouye. 1988. Long-term vegetation dynamics of vegetation in a sagebrush steppe of southeastern Idaho. Ecological Studies Program, Idaho National Engineering Laboratory. Final Report.

Anderson, J. E., R. J. Jeppson, R. J. Wilkosz, G. M. Marlette, and K. E. Holte. 1978. Trends in vegetation development on the Idaho National Engineering Laboratory Site. Pages 144-166 in O. D. Markham, ed., Idaho National Engineering Laboratory Site, 1978 Progress Report. Idaho Operations Office, U.S. Department of Energy, Idaho Falls.

Anderson, J. E., K. T. Ruppel, J. M. Glennon, K. E. Holte, and R. C. Rope. 1996. Plant communities, ethnoecology, and flora of the Idaho National Engineering Laboratory. ESRF-005, Environmental Science and Research Foundation, Idaho Falls, Idaho.

Harniss, R. O. and N. E. West. 1973a. Changes in Artemisia tridentatalSitanion hystrix vegetation on the National Reactor Testing Station, southeastern Idaho. 1950 - 1965. Utah Academy Proceedings 50:10-16.

---. 1973b. Vegetation patterns of the National Reactor Testing Station, southeastern Idaho. Northwest Science 47:30-43. 
Tilman, D. 1996. Biodiversity: Population versus ecosystem stability. Ecology 77:350-363.

Tilman, D., D. Wedin, and J. Knops. 1996. Productivity and sustainability influenced by biodiversity in grassland ecosystems.
Nature 379:718-720.

West, N. E. 1983. Western Intermountain sagebrush steppe. Pages 351-374 in N. E. West, ed., Temperate deserts and semi-deserts, Ecosystems of the World, 5th Edition. Elsevier, Amsterdam. 


\title{
HABITAT USE AND MOVEMENT PATTERNS OF MULE DEER ON THE INEEL
}

\author{
James M. Peek and David E. Beaver ${ }^{11}$
}

\begin{abstract}
Field work directed toward determining the seasonal distribution., habitat use and density of mule deer (Odocoileus hemionus) on the INEEL was continued throughout the calendar year. In December, data sets were officially closed and compilations began. Vegetation samples have been sent to the laboratory and the results are near complete. Several accuracy assessments of systems used in this study have been performed and preliminary results are available. Movement and location data on all collared animals are being analyzed and prepared for reporting. Survey forms directed toward landowners adjacent to the INEEL were designed and reviewed. Crucial Geographic Information System (GIS) database files were acquired and the computer resources necessary for their analysis secured.
\end{abstract}

Keywords: Mule deer, habitat use, depredation.

\section{JUSTIFICATION}

Little is known about the ecology and behavior of mule deer in sagebrush-steppe habitats, in general, and on the INEEL in particular. On the INEEL, deer appear to concentrate around facilities during certain times of the year, especially during severe winter conditions. The high visibility of these animals makes their well being a concern to site workers and visitors and hence a public relations issue. These animals can cause significant damage to landscape shrubbery and ornamental vegetation around facilities. For this reason there is interest in determining if forage can be modified in such a manner that would positively accommodate mule deer and site facilities. There is concern regarding depredation these animals may be causing on surrounding croplands. This potential problem is being initially addressed through a survey of landowners adjacent to INEEL property.

The lands of the INEEL, which are designated as a National Environmental Research Park, constitute a possibly crucial area of winter habitat for regional populations of mule deer, and present a rare opportunity to investigate the unique type of habitat that is represented by the sagebrush steppe of the upper Snake River Plain. Local game management agencies are under considerable pressure from both consumptive and non-consumptive users to protect and provide for wildlife populations under their jurisdiction. Therefore, management of these populations is important not only to the INEEL, but also to other stakeholders involved in the regulation, management, and conservation of wildlife. Regulation and conservation activities are possible only if a basic understanding of mule deer requirements are known. Information from this study will allow DOE to knowledgeably discuss wildlife issues with management agencies and stakeholders, such as the Shoshone-Bannock Tribes, the Idaho Department of Fish and Game, and the Bureau of Land Management, and help make informed decisions regarding the management of deer on and near the INEEL.

\section{Objectives}

The objectives of this research are to:

- Determine habitat use by deer in relation to domestic livestock grazing, patch size of habitat and type of habitat.

- Determine selective preference in homogeneous habitat between non-treated and land-surface waste-water application areas.

- Determine seasonal movements of mule

"University of Idaho, College of Forestry Wildlife and Range Science, Moscow, ID 83848 
deer on the INEEL.

- Estimate mule deer depredation on croplands adjacent to the INEEL.

- Estimate mule deer densities on the INEEL.

- Investigate the feasibility of establishing green strips to supplement winter forage and serve as fire breaks.

- Investigate possible effects of prescribed burns on big game habitat use on the INEEL.

\section{PROJECT ACCOMPLISHMENTS}

During 1996, field work concentrated on the continuation of radio-tracking free ranging deer. A total of 374 locations of radiocollared deer were determined and recorded throughout the year. Of these, 338 locations were recorded from the ground and 36 were recorded from the air using a fixed-wing aircraft. All radio-telemetry locations were validated and augmented by the collection of visual animal locations. These were collected by homing in on an animals signal and collecting a Global Positioning System (GPS) location at the point of visual contact.

A system of 163 receiver sites, formally established to increase the accuracy of radio-telemetry efforts, have had their location verified using GPS. These sites were located on strategic points of relatively higher elevation, providing a vantage point that allowed detection of radio signals for considerable distances. The primary purpose of these sites was to facilitate efficient and accurate telemetry location of collared animals. The accuracy of this technique in this environment was assessed.

Data for a GPS accuracy assessment was collected using well-head markers located across the INEEL.

Vegetation samples were collected in both deer and random locations. Samples were used to investigate two aspects of mule deer habitat, the structure of the habitat and the nutritive parameters of the environment. Forty-six vegetation samples were collected for micro/macro nutrient analysis and 33 cover/composition samples were collected.

Analysis of the nutritive aspects of the habitat was designed to determine if there was a correlation between weather variables and forage quality. For this analysis two forage species were chosen, green rabbitbrush (Chrysothamnus vicidiflorus) and crested wheatgrass (Agropyron cristatum) due to their availability across the site and their frequent listing in pertinent literature as being preferred browse species. These samples were collected once each month except in the spring when samples are collected three times each month. Analysis is being conducted by the Analytical Services Laboratory at the University of Idaho and includes protein level, trace element and micronutrient content. Statistical analysis of this data is pending. Results will be correlated with weather data to attempt prediction of population responses.

A pilot study was performed using a limited number of animals to assess the applicability of several software applications and design specifications to habitat use and availability.

Several useful Geographic Information System databases were obtained from the Center for Integrated Environmental Technologies. These include vegetation, hydrology, utility, and topography coverage of those areas that mule deer are inhabiting.

A comprehensive survey intended to determine concerns of adjacent landowners was drafted reviewed and printed. This survey, developed with the assistance of a Foundation communicationleducation specialist and sociologists from the University of Idaho, was designed to determine various attitudes of those persons who may be most affected by the animals that inhabit the 
INEEL lands. The survey is intended to assist DOE land managers in addressing their public relations concerns. This survey is slated for distribution in January 1997.

A draft manuscript entitled, "Review of supplemental feeding of big game in Western North America and Central Europe," was written. The manuscript contained an extremely thorough history and evaluation of supplemental feeding of big game. A section of the manuscript specifically discussed the pros and cons of supplemental feeding of big game on the INEEL, which would include the establishment of green strips to supplement winter forage.

\section{IMPORTANT RESULTS}

The results of accuracy assessments showed that the GPS system used in this study provided locations accurate to within 2.6 meters and that the average telemetry error was about 6.0 degrees.

Preliminary findings from location data indicate that mule deer use of the INEEL is variable. Some animals have maintained their ranges within site boundaries throughout the year, while others have moved offsite into agriculture areas and adjacent undeveloped areas close to croplands. These movement patterns start to reveal behavior that was not entirely predicted. Some animals have made seasonal moves as far as $50 \mathrm{~km}$, a distance that was quite unexpected for mule deer in this habitat at that particular time of year. One behavior that was observed was the movement of several animals into the lava flows east of the site boundary that seemed to coincide with fawning. This movement was relatively sudden, occurred with several animals at the same time and was repeated for both years. Also, the fawning season revealed a distinct use of areas that provided more hiding cover.

Upon the approach of winter most animals returned to the same relative area where they spent the previous winter. Several animals stayed within the same general area for the entire year. This pattern was observed over the course of two field seasons. Of the 20 original animals collared, seven have died. Two of these were killed by vehicles and five died of undeterminable causes.

The conclusion in the manuscript discussing the supplemental feeding of big game was that much depended on management philosophies. The INEEL represents one of the largest undisturbed expanses of native sagebrush steppe and opportunities to investigate big game behavior in this habitat exist. If scientific values predominate, it would be unwise to supplementally feed and alter big game behavior and natural population fluctuations. On the other hand, large die-offs are distasteful to people, so if social and esthetic values predominate, supplemental feeding of big game may maintain more animals for the enjoyment of humans.

\section{PRODUCTS}

This study is in the data analysis stage. Software applications have been developed that will identify those areas of potential preferred use compared to other areas that are available to mule deer on site. A manuscript entitled, "Review of supplemental feeding of big game in Western North America and Central Europe," was written and is in review. Landowner survey forms have been completed and are awaiting prearranged mailing dates in 1997. 


\title{
PLUTONIUM DISTRIBUTION AMONG SOIL PHASES AROUND THE SUBSURFACE DISPOSAL AREA AT THE IDAHO NATIONAL ENGINEERING AND ENVIRONMENTAL LABORATORY
}

\author{
Shawki A. Ibrahim ${ }^{12}$
}

\begin{abstract}
The use of total transuranic concentrations as a criterion to assess the potential risk of contaminated soil implies that all geochemical forms of these radionuclides have an equal impact on man and his environment. However, the degree of ecological mobility and bioavailability of these elements are limited, making the above assumption unrealistic. The goal of this project is to study the association of plutonium in six different chemical and mineralogical soil phases as a function of depth in the soil profile. The association is studied using sequential extraction experiments. We collected 100 soil samples from five locations near the Subsurface Disposal Area (SDA) at the Idaho National Engineering and Environmental Laboratory (INEEL). Each location was sampled to 30-cm soil depth in 3-cm layers. All soil samples were dried, mixed, and screened through a $0.5-\mathrm{mm}$ mesh. We selected $10-\mathrm{g}$ aliquots for $\mathrm{Pu}$ analysis and for the sequential extraction experiments. Post extraction readsorption was tested by tracer experiments. From this information, we will assess the relative environmental transport of the different chemical and physical forms of $\mathrm{Pu}$.
\end{abstract}

Keywords: Plutonium, sequential extraction, Subsurface Disposal Area, environmental transport.

\section{JUSTIFICATION}

From 1954 through 1970, transuranic waste from the Rocky Flats Plant was shipped to the Idaho National Engineering Laboratory (INEEL). Markham et al. (1978) reported that $21,000 \mathrm{Ci}$ of ${ }^{239} \mathrm{Pu}$ and $570 \mathrm{Ci}$ of ${ }^{238} \mathrm{Pu}$ were buried at the Subsurface Disposal Area (SDA) of the INEEL Radioactive Waste Management Complex (RWMC). The majority of this waste was buried in pits in the SDA. After the pits were filled, they were leveled to grade by covering the waste with approximately $1.0 \mathrm{~m}$ of soil. Additional soil (as much as $1.0 \mathrm{~m}$ in some locations) was added in the early 1980 s to contour the SDA and promote runoff.

Soil samples collected near the SDA indicated $\mathrm{Pu}$ contamination outside the SDA perimeter (Markham et al. 1978). Maximum concentrations in surface soil $(0$ to $4 \mathrm{~cm})$ occurred in the drainage depression near the perimeter of the SDA. Surface water runoff and wind appear to be the primary mechanisms transporting these radionuclides out of the SDA.

Although knowledge about the total concentrations of these contaminants in the soil matrix is important in appraising the potential hazard, these are not sufficient data to assess potential transport and movement in soil and ground or surface water. In order to better understand the availability and mechanisms of $\mathrm{Pu}$ transport in the environment, we initiated a sequential extraction experiment of soil from around the SDA. Improving our understanding of transuranic association in soil phases aids in the performance of reliable ecological and human health risk assessments and helps establish tenable and defendable cleanup standards based on the actual mobility of these radionuclides in the environment. This project provides factual data for scientific purposes by an independent, scientificallyestablished group, which should enhance the public acceptability and credibility of the resulting information.

This work addresses some of the ecological risk and impact assessment requirements of RCRA/CERCLA and NEPA programs at INEEL. These programs need site specific environmental research to support decisions and documentation for

${ }^{12}$ Department of Radiological Health Sciences, Colorado State University, Fort Collins, CO 80523 
remediation and restoration programs. Additionally, this project provides training for a graduate student in health physics and radioecology. The Department of Energy stated a need for such training to meet longrange environmental restoration goals.

In 1994, after we developed the necessary protocols and procedures, we collected 100 soil samples from five locations near the SDA. Each location was sampled to $30-\mathrm{cm}$ soil depth in 3-cm layers. A gamma spectroscopy measurement was conducted on all field locations. We transported all samples to Colorado State University where we began sample pretreatment and analyses for postextraction readsorption.

\section{OBJECTIVES}

The objectives of this project are to:

- Determine the extent of vertical distribution of $\mathrm{Pu}$ isotopes in soil profiles from the SDA.

- Study the association of these radionuclides in six important chemical and mineralogical soil phases controlling their transport in soils and seep waters. The soil fractions obtained by sequential extraction are soluble, exchangeable, carbonate, organic, sesquioxide, and silicate.

- Assess the degree of post-extraction readsorption using radiotracers including ${ }^{234} \mathrm{Th}$ and ${ }^{237} \mathrm{~Np}$.

\section{PROJECT ACCOMPLISHMENTS}

- We completed the preliminary sample pretreatment including drying, grinding and sieving for all the samples.

- We completed work using ${ }^{234} \mathrm{Th}$ and ${ }^{237} \mathrm{~Np}$ tracers to assess the degree of postextraction readsorption for the soil sequential extraction.

- We submitted aliquots from 50 soil samples to the CSU Soil Testing Laboratory for general chemical and physical characterization (bulk density, $\mathrm{pH}$, texture, organic and carbonate content, etc.). This effort has been completed and the results will be used to interpret the sequential extraction work.

- We will present the factors that control the possible movement and transport of plutonium in the study area under environmental scenarios in a manuscript being prepared for publication.

\section{IMPORTANT RESULTS}

Preliminary data analysis suggest that postextraction readsorption contribution is minor. Hence, Pu partitioning among the different soil phases can be evaluated with a high degree of accuracy using the proposed sequential extraction scheme.

Results from the sequential extraction suggest that plutonium is associated among the different soil phases as follows:

- A significant fraction $(37 \pm 5 \%)$ of the plutonium is associated with the sesquioxides (soil coatings) fractions.

- $22 \pm 3 \%$ is associated with the soil organic matter.

- $14 \pm 3 \%$ of plutonium is associated with the carbonate fraction of the soils.

- Less than $4 \%$ is associated with the soluble and exchangeable fractions.

- The remainder $(21 \pm 5 \%)$ of the plutonium is strongly bound to the silicate fraction of the soils. 
- Most of the plutonium inventory at the SDA still resides in the upper soil horizon.

\section{PRODUCTS}

- The study site characterization was summarized in a report submitted to the Environmental Science and Research Foundation (Ibrahim and Stone 1995).

- We presented some results from the sequential extraction experiments at the First Annual University of Colorado Public Interest Science Conference held November 4, 1995, in Boulder, Colorado.

- We are in the process of finalizing a manuscript for submission to $J$. Radioanalytical and Nuclear Chemistry (now under DOE review).

\section{LITERATURE CITED}

Ibrahim, S. A. and J. A. Stone. 1995.

Sampling and site characterization of soils around the waste management complex at Idaho National Engineering Laboratory. Colorado State University, Fort Collins, CO. 20 pp.

Ibrahim, S. A. 1994. Sampling protocol and procedures for plutonium distribution among soil phases around the Subsurface Disposal Area at the Idaho National Engineering Laboratory. Colorado State University, Fort Collins, CO. 5 pp.

Markham, O. D., K. W. Puphal, and T. D. Filer. 1978. Plutonium and americium contamination near a transuranic storage area at Southeastern Idaho. Journal of Environmental Quality 7:442-428. 


\title{
LICHENS AS AIR POLLUTION BIOMONITORS AT THE IDAHO NATIONAL ENGINEERING AND ENVIRONMENTAL LABORATORY ${ }^{13}$
}

\author{
Lorentz C. Pearson ${ }^{14}$
}

\begin{abstract}
In previous studies involving lichens as air pollution biomonitors at the INEEL, electrolyte leakage tests demonstrated that, in an arid or semiarid climate, lichens are injured most when they are moist from early morning dew. We used Energy Dispersive Spectroscopy (EDS) and Secondary Ionic Mass Spectroscopy (SIMS) to assay dispersal and concentration of polluting elements. Thirteen of 21 trace elements were higher in concentration on the nighttime downwind transect $\left(215^{\circ}\right)$, while two were higher on the daytime downwind transect $\left(55^{\circ}\right)$. Two elements $(\mathrm{Pb}$ and $\mathrm{S})$ were highest in concentration along the crosswind transects. Magnesium was more abundant in lichens further from the ICPP. Because Mg is associated with chlorophyll, this may indicate healthier lichens further from the ICPP. Use of SIMS demonstrated isolation of some ions in cellular structure and found lithium in lichens samples on the night-time, downwind transect from ICPP. Four manuscripts summarizing recent lichen research on the INEEL were prepared. Identifications of all specimens in the INEEL lichen herbarium have been independently verified.
\end{abstract}

Keywords: Air pollution, biomonitors, energy dispersive spectroscopy, lichens, scanning electron microscopy, secondary ionic mass spectroscopy.

\section{JUSTIFICATION}

Since the beginning of the Industrial Revolution in the late eighteenth century, the abundance of some kinds of plants has been decreasing in urban areas and near factories and smelters. This reduction is generally attributed to toxic gases such as sulfur dioxide, nitrogen oxides, ozone, carbon monoxide, hydrogen fluoride, and peroxyacyl nitrates in smokestack effluents. Most lichens are excellent indicators of pollution because they are sensitive to toxic gases. Those that are relatively tolerant, compared to other lichens, are also valuable indicators. From the combination of sensitive and tolerant species present, an air quality index can be constructed to evaluate pollution.

Lichens are also valuable as pollution indicators because they accumulate heavy metals and other polluting elements in their tissues (Rope and Pearson 1990). To more readily identify the chemical elements given off by a point source of pollution, such as the Idaho Chemical Processing Plant (ICPP), we developed a microchemical assay method. Thin, free-hand lichen tissue sections are examined by scanning electron microscopy (SEM) and energy dispersive spectroscopy (EDS). The relative concentration of each element is calculated with the aid of Gaussian deconvolution and specialized computer software. The method correlates reasonably well with traditional macrochemical methods, is somewhat less expensive, and is environmentally friendly. We developed this technique to provide the Department of Energy (DOE) with an inexpensive method to assess environmental contamination from hazardous air pollutants and associated risks.

We also investigated the use of secondary ionic mass spectroscopy (SIMS) as a method for detecting pollutants in lichens. Imaging SIMS has the potential to offer a second assay to confirm the SEM and EDS data and to provide data on boron, fluorine, molybdenum, and other ions that EDS cannot measure quantitatively.

\footnotetext{
${ }^{13}$ Editors' Note: Dr. Pearson died in early 1997. We compiled this report from his regular monthly reports to the Foundation and early drafts of his manuscripts. The products listed here are currently in the hands of his family and their status is uncertain.

${ }^{14}$ Ricks College (Retired), Rexburg, ID 83440
} 


\section{Objectives}

Objectives of these studies at the INEEL include:

- Use lichens as biomonitors to provide a continuous record of atmospheric quality at the INEEL and surrounding areas.

- Develop environmentally friendly microchemical assay methods for heavy metals and other polluting elements in lichen tissue.

- Inventory of lichens and other plants (e.g. mosses) that might be used as biomonitors.

- Evaluate the more common and abundant species for their usefulness as biomonitors.

- Organize the INEEL lichen herbarium for use as a reference collection.

- Publish our results to benefit the public or other scientists engaged in air quality research, environmental protection, conservation, or lichen physiology.

\section{PROJECT ACCOMPLISHMENTS}

In 1996, research focused on all these objectives. We placed special emphasis on publishing data for selection of species most useful in biomonitoring studies. Most significantly, we:

- Statistically analyzed trace element data for a number of species found on the INEEL relative to distance and direction from the ICPP.

- Tested HF fumigated and nonfumigated samples of Letharia vulpina using imaging SIMS.
- Obtained independent confirmation of identification of specimens in the INEEL lichen herbarium.

- Produced four manuscripts based on data collected in this project.

\section{IMPORTANT RESULTS}

- There were statistically significant differences in concentrations of trace elements in lichens among radial transects from the ICPP. Thirteen of 21 elements were higher in concentration on the nighttime downwind transect $\left(215^{\circ}\right)$, while two were higher on the daytime downwind transect $\left(55^{\circ}\right)$. Two elements ( $\mathrm{Pb}$ and $\mathrm{S}$ ) were highest in concentration along the crosswind transects.

- Magnesium was more abundant in lichens further from the ICPP. Because $\mathrm{Mg}$ is associated with chlorophyll, this may indicate healthier lichens further from the ICPP.

- Imaging SIMS showed homogenous distributions of most ion species in HF fumigated and nonfumigated lichen tissue. Exceptions were magnesium and fluorine which were both found concentrated in limited areas. These concentrations may have been with membrane bound, cellular structures. Presumably magnesium was limited to chloroplasts. The structure isolating fluorine has not yet been determined.

- Imaging SIMS data indicated highest levels of lithium in lichens on the $215^{\circ}$ (night-time downwind) transect. This suggested that these lichens take in lithium when they are moist from morning dew. This result is important because lithium cannot be detected accurately by EDS or other microchemical techniques. 
- EDS and SIMS both show promise as environmentally friendly methods of using lichens as biomonitors.

\section{PRODUCTS}

We prepared four manuscripts for publication in 1996. These manuscripts are currently under Foundation review or have been submitted to the indicated journals.

- Pearson, L. C. In review. Lichens as bioindicators of air quality at the Idaho National Engineering Laboratory. Great Basin Naturalist.

- Pearson, L. C. In review. Biomonitoring air quality with lichens using electrolyte leakage and energy dispersive spectroscopy. Bryologist.

- Pearson, L. C. Ready for Submission. Air pollution damage to cell membranes in lichens IV. Lichens of arid regions. Northwest Science.

- Pearson, L. C. In review. Environmentally friendly microchemical methods for biomonitoring air quality with lichens. Journal of Applied Ecology.

\section{LITERATURE CITED}

Rope, S. K., and L. C. Pearson. 1990. Lichens as air pollution biomonitors in a semiarid environment in Idaho. The Bryologist 93:50-56. 


\title{
BREEDING BIRD SURVEYS AT THE IDAHO NATIONAL ENGINEERING AND ENVIRONMENTAL LABORATORY
}

\author{
James R. Belthoff ${ }^{15}$
}

\begin{abstract}
Breeding birds on thirteen permanent survey routes located at the Idaho National Engineering and Environmental Laboratory were censused between 11 - 24 June 1996. A total of 5,037 individuals representing 54 species of birds was recorded. These birds included two species not previously recorded along the routes: northern mockingbird (Mimus polyglottos) and western grebe (Aechmophorus occidentalis). Eleven of 54 species were more abundant than in previous years (i.e., greater than 2.5 standard deviations above their 1985-1991 means), including horned larks (Eremophila alpestris), sage thrashers (Oreoscoptes montanus), mourning doves (Zenaida macroura), Brewer's blackbirds (Euphagus cyanocephalus), common ravens (Corvus corax), house finches (Carpodacus mexicanus), American coots (Fulica americana), cliff swallows (Hirundo pyrrhonota), lesser scaup (Aythya affinis), mountain bluebirds (Sialia currucoides), and blue-gray gnatcatchers (Polioptila caerulea). None of the species observed in 1996 were more than 2.5 standard deviations below their 1985-1991 average abundance. For 1985-1991, no significant differences were detected between facility complex routes and remote routes for mean number of birds per stop, species richness, average number of birds per stop, and diversity index. However, species composition varied between the two route types and the coefficient of variation was higher for facility complex routes. Species of special concern recorded along the survey routes in 1996 included loggerhead shrikes (Lanius ludovicianus, $\mathrm{N}=16$ ), ferruginous hawks (Buteo regalis, $\mathrm{N}=9$ ), Swainson's hawks (Buteo swainsoni, $\mathrm{N}=5$ ), and long-billed curlews (Numenius americanus, $\mathrm{N}=1$ ).
\end{abstract}

Keywords: Breeding birds, breeding bird surveys, environmental impacts, sensitive species.

\section{JUSTIFICATION}

The Breeding Bird Survey (BBS) is a roadside route survey in the United States and southern Canada, which now has over 3000 survey routes (Bystrak 1981, Robbins et al. 1986). Begun in the eastern U.S. in 1966, the BBS was designed to detect changes in population levels of entire species. It is now nationwide in scope and is one of the U.S. Geological Survey, Biological Resources Division's (BRD) main sources of information on trends in avian population across the continent. Because methods are standardized, comparisons across years and regions of the country are possible, and many local or regional assessments have been conducted (e.g., Geissler and Noon 1981, Holmes and Sherry 1988, Sauer and Droege 1990). The BBS has been particularly useful in documenting population declines in neotropical migrants (Robbins et al. 1989). We are using this technique at the Idaho National Engineering and Environmental
Laboratory (INEEL) to monitor annual fluctuations in the breeding birds and to assess impacts of INEEL activities on the avifauna.

Thirteen permanent avian survey routes were established at the INEEL in 1985 . Five of the routes were located in remote, relatively pristine regions and were standard $40 \mathrm{~km}$ BRD Bird Survey routes. The other eight routes were positioned around facility complexes and were generally shorter than 40 $\mathrm{km}$ in length. Each of the survey routes has been censused each June since 1985, with the exceptions of 1992 and 1993. During each census, the species and numbers of breeding birds, and the habitats they occupied, were recorded by observers. The data generated from these surveys are particularly important because they provide an opportunity to assess effects of INEEL activities on avian communities and to reveal differences, if any, in numbers of birds, numbers of species, and species richness between facility complex and remote routes. The data also can be used to

\footnotetext{
${ }^{15}$ Department of Biology, Boise State University, Boise, ID 83725
} 
assess how biodiversity on the INEEL changes over time, to identify important indicator species, and to assess changes in bird species and numbers resulting from INEEL activities at specific Waste Area Groups (WAGs). Finally, data from the surveys allow documentation of patterns of natural multi-year variation in bird populations, which will facilitate comparisons with future study efforts on the INEEL.

\section{Objectives}

The objectives of the 1996 study were to:

- Survey the 13 permanent routes for breeding birds during June - July.

- Update the computerized database maintained at Boise State University with the 1996 data.

- Assess 1996 bird survey data in relation to the longer-term data contained in the database.

- Respond to queries by DOE, INEEL contractors, and other agencies for information on breeding bird species and abundance at the Idaho National Engineering and Environmental Laboratory.

- Complete work on the manuscript summarizing the $1985-1991$ surveys and submit it to Great Basin Naturalist for publication.

\section{PROJECT ACCOMPLISHMENTS}

In 1996, we:

- Submitted one technical manuscript on breeding birds at the INEEL (1985 - 1991) to Great Basin Naturalist. The manuscript is currently being revised along lines suggested by reviewers and the editor.
- Surveyed the permanent breeding bird survey routes between 11 - 24 June 1996.

- Updated the computerized database of breeding birds (maintained at Boise State University) to include 1996 data.

- Responded to queries from Environmental Science and Research Foundation, Idaho Fish and Game, and others for information on breeding birds at INEEL.

\section{IMPORTANT RESULTS}

For 1985-1991, no statistical differences were measured for mean number of birds per stop, species richness, average number of birds per stop, and diversity index between facility complex routes and remote routes. However, the coefficient of variation was higher for facility routes and the species composition between the two route types varied. Only two of 14 species of waterfowl were observed along remote routes. Of the 12 species of raptors documented, all occurred equally on facility complex and remote routes with the exception of Swainson's hawks (Buteo swainsoni), and burrowing owls (Speotyto cunicularia), which occurred along $80-100 \%$ of the remote routes and only $25-$ $38 \%$ of the facility complex routes. Cooper's hawks (Accipiter cooperii), and merlins (Falco columbarius) were only observed on remote routes.

During 1996, 5,037 individual birds were recorded along the 13 survey routes, which is greater than the 1985 - 1991 average of 3,655 birds per year. Overall, there was an average of 387.5 birds per route and 10.3 birds per stop. Remote routes had more birds per stop (an average of 11.1 birds) than facility routes (9.4 birds per stop).

A total of 54 species were detected during the 1996 surveys. Two species, western grebe (Aechmophorus occidentalis) and northern 
mockingbird (Mimus polyglottos), were recorded along the survey routes for the first time in 1996.

As in previous years of the surveys, the five most numerous species (in order of abundance) were horned larks, Eremophila alpestris; western meadowlarks, Sturnella neglecta; sage sparrows, Amphispiza belli; Brewer's sparrows, Spizella breweri; and sage thrashers, Oreoscoptes montanus, comprising $73.2 \%$ of the birds detected.

Species recorded in numbers noticeably larger than during previous years (i.e., greater than 2.5 standard deviations above 1985 1991 averages) were horned larks, sage thrashers, mourning doves (Zenaida macroura), Brewer's blackbirds (Euphagus cyanocephalus), common ravens (Corvus corax), house finches (Carpodacus mexicanus), American coots (Fulica americana), cliff swallows (Hirundo pyrrhonota), lesser scaup (Aythya affinis), mountain bluebirds (Sialia currucoides), and blue-gray gnatcatchers (Polioptila caerulea). Of the species observed in 1996, none was more than two standard deviations below its 1985 - 1991 mean.

A relatively low number of loggerhead shrikes $(\mathrm{N}=16)$ were observed in 1996 and may be noteworthy because this is a species of special concern in Idaho (Mosely and Groves 1994). The number of shrikes in 1996 was slightly more than one standard deviation below the 1985-1991 mean of 40 shrikes per year, and this is consistent with the analyses of Belthoff et al. (in revision) which indicated an apparent downward trend in loggerhead shrike populations on the INEEL. Other species of special concern observed during the 1996 census included Swainson's hawks, ferruginous hawks (Buteo regalis), and long-billed curlews (Numenius americanus).

\section{PRODUCTS}

One annual technical report (listed below) summarizing the important results of the 1996 surveys was prepared and submitted for Foundation approval.

Belthoff, J. R. and E. A. Ellsworth. 1996. 1996 breeding bird surveys at the Idaho National Engineering and Environmental Laboratory, $30 \mathrm{pp}$.

One manuscript resulting from previous years of the breeding bird survey efforts (1985 - 1991) was submitted to Great Basin Naturalist after review by DOE, and is currently in revision.

Belthoff, J. R., L. R. Powers, T. D. Reynolds. In revision. Breeding birds at the Idaho National Engineering and Environmental Laboratory, 1985 - 1991. Great Basin Naturalist.

\section{LITERATURE CITED}

Belthoff, J. R., L. R. Powers, T. D. Reynolds. In revision. Breeding birds at the Idaho National Engineering Laboratory, 1985 1991. Great Basin Naturalist.

Bystrak, D. 1981. The North American breeding bird survey. Studies in Avian Biology 6:34-41.

Geissler, P. H. and B. R. Noon. 1981. Estimates of avian population trends from the North American Breeding Bird Survey. Studies in Avian Biology 6:42-51.

Holmes, R. T. and T. W. Sherry. 1988. Assessing population trends of New Hampshire forest birds: local vs. regional patterns. Auk 105:756-768.

Mosely, R. and C. Groves. 1994. Rare, threatened, and endangered plants and animals of Idaho. Conservation Data Center, Idaho Dept. of Fish and Game, Boise. $39 \mathrm{pp}$.

Robbins, C. S., D. Bystrak, and P. H. Geissler. 1986. The Breeding Bird Survey: its first fifteen years, 1965 - 1979. U.S. Fish and Wildlife Service Resource Publication 157. $196 \mathrm{pp}$. 
Robbins, C. S., J. R. Sauer, R. S. Greenberg, and S. Droege. 1989. Population declines in North American birds that migrate to the neotropics. Proceedings of National Academy of Sciences 86:7658-7662.
Sauer, J. R. and S. Droege, editors. 1990. Survey designs and statistical methods for the estimation of avian population trends. U.S. Fish and Wildlife Service Biological Report 90.166 pp. 


\title{
MONITORING AMPHIBIAN AND REPTILE POPULATIONS ON THE IDAHO NATIONAL ENGINEERING AND ENVIRONMENTAL LABORATORY: INDICATORS OF ENVIRONMENTAL HEALTH AND CHANGE
}

\author{
Sarah L. Cooper and Charles R. Peterson ${ }^{16}$
}

\begin{abstract}
In 1996, we continued monitoring amphibian and reptile populations on the Idaho National Engineering and Environmental Laboratory (INEEL). For the third year in a row, we monitored snake populations at three large den site locations. Because of low numbers of recaptured individuals in both 1995 and 1996, no reliable population estimates could be calculated. However, the low number of snake recaptures at the three monitoring locations indicates that the population numbers are large. In 1996, no new species were detected from the monitoring program. However, the known ranges of several species on the INEEL were broadened, notably the striped whipsnake (Masticophis taeniatus) and the desert night snake (Hypsiglena torquata), a BLM listed Sensitive species. Five Short-horned lizards (Phrynosoma douglassii) were observed during 1996, as opposed to none observed in 1995. Longnose Leopard lizards (Gambelia wislizenii) were observed at Circular Butte on three different occasions in 1996. No leopard lizards were observed at Antelope Butte, a site where these lizards have not been seen since 1975. Sagebrush lizards (Sceloporous graciosus), another sensitive species, were trapped or observed at all three monitoring locations. One Great Basin spadefoot toad (Spea intermontana) was trapped at Cinder Butte, compared to six last year. We located three spadefoot breeding sites on the INEEL in 1995. During 1996, we observed breeding at two of the three locations. Our monitoring indicates that the spadefoot tadpoles in the Big Lost River Sinks area were likely able to metamorphose, while the tadpoles in Spreading Area A probably were unable to fully metamorphose and thus perished, due to the short period water was in the area. Five venomous snake training sessions were held for INEEL employees this year, and all sessions received positive comments about the utility of the information. New sightings of reptiles and amphibians for the INEEL were entered into a computerized database developed in 1994 that will be used to describe the distribution and abundance of these animals on the INEEL. In addition, we improved and tested a GIS model developed in 1995 for predicting snake dens on the INEEL. The map generated from the GIS model can be used for making management decisions and in future surveys. To test our GIS map, we visited 50 sites within the predicted areas of the map and 50 sites that were outside of the predicted areas on the map. We determined that out of the 50 not-predicted sites, none showed any sign of snake activity. Sixteen of the 50 predicted areas showed snake activity and were considered to be either probable, possible, or confirmed den sites. The probable and possible den locations will be re-examined during the spring of 1997 to verify snake activity. The success of the model was tested using a Fisher's Exact test, and results were statistically significant. We consider the model to be a useful tool in predicting the occurrence of snake dens on the INEEL.
\end{abstract}

Keywords: Amphibians, desert night snakes, geographic information systems, Great Basin spadefoot toads, rattlesnakes, reptiles, sagebrush lizards, species distribution.

\section{JUSTIFICATION}

Many amphibian and reptile species have biological characteristics that make them sensitive indicators of environmental change. Our primary research goal is to provide indicators of environmental health and change by monitoring the status of amphibian and reptile populations on the Idaho National Engineering and Environmental Laboratory (INEEL). Previous studies of amphibians and reptiles make the INEEL an excellent site for long-term monitoring studies. This research also provides information for appropriate management of sensitive amphibian and reptile species, including the INEEL's listed species, the desert night snake (Hypsiglena torquata) and the sagebrush lizard (Sceloporous graciosus). It will improve our knowledge of the distribution of amphibians and reptiles on the INEEL so that the Department of Energy (DOE) can avoid negative impacts of human activities on these animals and meet National Environmental Policy Act requirements regarding site developments. Knowledge of rattlesnake

${ }^{16}$ Department of Biological Sciences, Campus Box 8007, Idaho State University, Pocatello, ID 83209 
distribution on the INEEL will help locate new projects or facilities to minimize potentially dangerous (for both species) snake-human interactions. Finally, this project provides an excellent opportunity to inform the public about the environmental value of the INEEL. Reptiles, especially rattlesnakes, tend to capture the public imagination and representatives of television, films, and the print media have approached the Foundation affiliates performing this work regarding opportunities to report on their work at the INEEL.

The short-term goal of this project is to determine the distribution and population trends of amphibians and reptiles on the INEEL. This information is important for: (1) identifying and managing populations of sensitive species; (2) meeting NEPA requirements regarding the siting of future developments; (3) avoiding potentially dangerous snake-human interactions; (4) monitoring environmental health and change; and (5) providing a foundation for future research into the ecological importance of these species.

\section{Objectives}

The objectives for 1996 were to:

- Continue monitoring snake and lizard populations at three den sites on the INEEL (Cinder Butte, Crater Butte, and Rattlesnake Cave), and lizard populations at Circular Butte and Antelope Butte.

- Determine breeding areas for Great Basin spadefoot toads (Spea intermontana) if conditions conducive to breeding occur.

- Provide herpetological expertise as needed (e.g., safety training, specific site surveys, recommendations for minimizing deleterious effects of human activities on amphibian and reptile populations).
- Continue entering all current information on species distributions and abundances into a Geographic Information System (GIS) and updating dot-distribution maps.

- Test a GIS model for snake den site selection by visiting both predicted and not-predicted locations.

\section{PROJECT ACCOMPLISHMENTS}

- In order to determine the population trends of the reptiles and amphibians on the INEEL, we continued our monitoring at three den sites.

- We relocated and surveyed breeding areas for spadefoot toads on the INEEL.

- We assisted the INEEL this year by giving five venomous snake safety talks to INEEL employees.

These talks are offered as an educational opportunity for INEEL staff to learn about rattlesnakes on the INEEL, and are of considerable benefit where safety issues are concerned. A primary focus of these talks is to emphasize that the actual risk of being bitten by a poisonous snake on the INEEL is low, despite that fact that thousands of rattlesnakes occur on the site. All of the sessions received positive feedback from the employees about the usefulness of the talks. More snake safety talks are slated for the spring of 1997.

- The INEEL Herpetological database was updated and improved during the past year.

The dot-distribution maps for sagebrush lizards, leopard lizards, and short-horned lizards were created. These maps are linked to the INEEL Herpetological database, and new observations entered will be updated on the maps. Maps for the other reptile and 
amphibian species of the INEEL are currently being developed. These data are being used in a related project to test and refine Gap Analysis models (Scott et al. 1993).

- We developed a map of predicted rattlesnake den habitat on the INEEL.

\section{IMPORTANT RESULTS}

Trapping this year resulted in the detection of no new species for the INEEL. Unlike last year, no desert night snakes were captured at Crater Butte this year. However, a desert night snake skin was found in a crater area approximately 6 miles south of Crater Butte, expanding the known range of this secretive species on the INEEL. One Great Basin spadefoot toad was captured in a trap at Cinder Butte during the summer, compared to 6 in 1995. A striped whipsnake (Masticophis taeniatus) skin was found at a crater area about two miles southeast of Cinder Butte. This is the first confirmed whipsnake sign that has been found outside of the immediate Cinder Butte area. One racer (Coluber constrictor) was captured in a trap at Crater Butte in 1996. Leopard lizards (Gambelia wislizenii) were seen at Circular Butte on three different occasions in late May and early June; no leopard lizards were seen at Antelope Butte, although this area was visited on several occasions during the field season. Five short-horned lizards (Phrynosoma douglassii) were observed in the southern half of the INEEL this year, compared to none in 1995. Sagebrush lizards (a species of special concern) were observed or trapped at all three of the monitoring locations. Western skinks (Eumeces skiltonianus) were trapped or observed at both Crater Butte and Rattlesnake Cave. Although hundreds of snakes have been captured in our traps, the recapture rates are still too low to make reliable population estimates. The location that has the highest recapture rates, Rattlesnake Cave, has had only nine rattlesnake recaptures in the past two years. This low recapture rate indicates that the snake populations at the three monitoring locations are quite large. More reliable population estimates may be possible using recapture data after the 1997 trapping season. Alternatively, we could try to increase our sample size by conducting visual encounter surveys to supplement the trapping.

Two of the three known spadefoot breeding areas on the INEEL were found to be active in 1996. Breeding spadefoot toads occurred in both the Big Lost River Sinks and Spreading Area A in 1996. The overflow pond where the Big Lost River crosses Lincoln Boulevard was dry during the spring and summer and no amphibian activity was observed at this location. The river flowed long enough for the toads to metamorphose successfully in the Big Lost River Sink area; however, water was present for less than two weeks in the Spreading Area, and it is unlikely that larvae at this site were able to survive. On May 16, Spadefoot toads were heard at the Experimental Field Station, which is less than $1 / 2$ mile $(0.8 \mathrm{~km})$ away from the Big Lost River, and close to 4 miles (6.4 $\mathrm{km}$ ) from the nearest known spadefoot toad population.

The map resulting from the predictive model of snake den locations displayed less than one percent of the total area of the INEEL as potential snake den habitat. During the spring and fall snake activity periods, we searched 50 randomly selected predicted areas, and 50 randomly selected areas that were outside of the predicted areas. None of the non-predicted areas showed any signs of snake activity, and the majority of the predicted areas did not show any signs of snake activity (Fig. 22, Fig. 22). However, a total of 16 locations that were predicted and searched were considered to be possible, probable, or confirmed den areas. The probable and possible den locations will be re-examined in the spring of 1997 to verify snake activity. The predicted and non-predicted data were tested for 

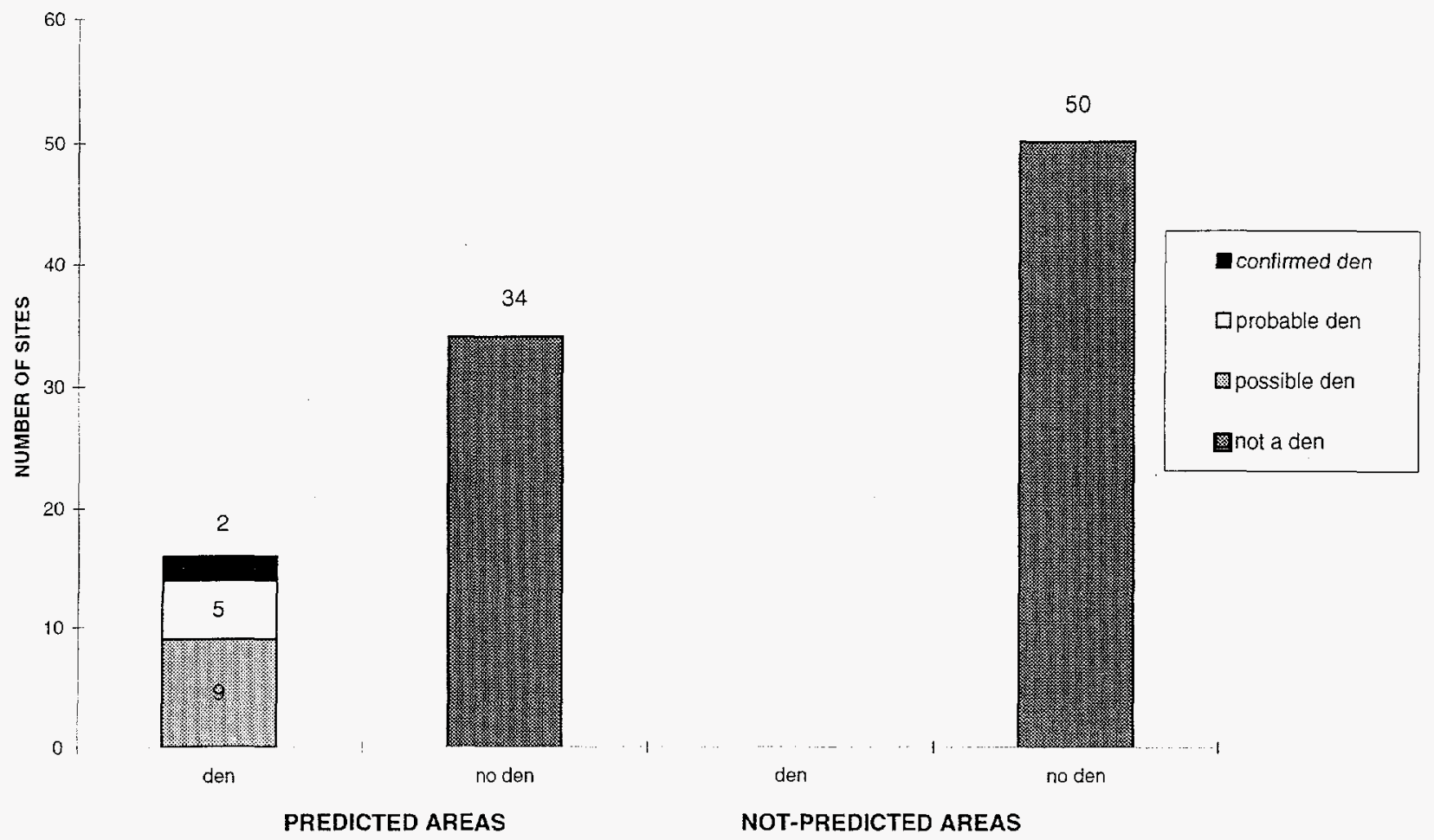

PREDICTED AREAS

NOT-PREDICTED AREAS

Fig. 22. Results of a search for rattlesnake dens based on the predictive model. Out of the 50 predicted sites searched, 34 were not dens, 9 were possible dens, 5 were probable dens, and 2 were confirmed dens. None of the non-predicted areas exhibited snake activity.

significance with contingency table analysis using a Fisher's Exact test. The results were significant at the 0.05 level using 16 likely sites out of the 50 that were predicted to be denning areas. However, even if all of the nine dens that are considered "possible" are dropped from the analysis after the spring 1997 searches, using the seven remaining probable and confirmed dens still yields statistically significant results $(\mathrm{P}=0.012)$. We consider the model to be a useful tool in predicting the occurrence of snake dens on the INEEL.

\section{PRODUCTS}

Two publications, two technical presentations, two children's educational presentations, and five snake safety presentations were given in 1996. 
Publications

Cooper, S. L. 1996. Geographic distribution of the Desert Night Snake (Hypsiglena torquata). Herpetological Review. 27(4):213.

Cooper, S. L. In Press. Idaho Species Account: Great Basin Spadefoot (Spea intermontana). Idaho Herpetological Society Newsletter.

\section{Technical Presentations}

Cooper, S. L. and C. R. Peterson. 1996. Modeling the location of snake dens on the Idaho National Engineering Laboratory. Platform Presentation, American Fisheries Society Meetings. March 1, 1996, Logan, UT.

Cooper, S. L. and C. R. Peterson. 1996.

Modeling the location of snake dens.

Platform Presentation, Idaho

Herpetological Society Meetings.

November 9, Boise, ID.

\section{Educational Presentations}

Cooper, S. L. 1996. The Irrepressible Reptiles of Idaho. Invited Presentation,
Science Trek, Idaho Museum of Natural History. April 21, Pocatello, ID.

Cooper, S. L. 1996. The Natural History of Snakes in Bannock County. Invited Presentation, Hawthorne Junior High Field Trip to Cherry Springs. June 4, Pocatello, ID.

\section{Snake Safety Presentations}

Cooper, S. L. 1996. Snake Safety on the Idaho National Engineering Laboratory. Invited Presentations:

- August 7

- September 10

- September 17

- October 8

- October 30

Fleet Management CFA Medical Staff Fleet Management CFA Fire Crew TAN Fire Crew

\section{LITERATURE CITED}

Scott, J. M., F. Davis, B. Csuti, R. Noss, B. Butterfield, C. Groves, H. Anderson, S. Caicco, F. D. Erchia, T. C. Edwards, Jr., J. Ulliman, and R. G. Wright. 1993. Gap analysis: a geographic approach to protection of biological diversity. Wildlife Monographs No. 123. 41 pp. 


\title{
HONEY BEES AS SENTINELS OF ENVIRONMENTAL HAZARDS AT THE IDAHO NATIONAL ENGINEERING AND ENVIRONMENTAL LABORATORY
}

\author{
Jerry J. Bromenshenk ${ }^{17}$, Garon C. Smith ${ }^{18}$, and Ted J. Christian ${ }^{17}$
}

\begin{abstract}
We deployed bee colonies on the Idaho National Engineering and Environmental Laboratory (INEEL) and its surroundings; periodically collecting and analyzing forager bees for a wide array of chemicals. From residue data, we assessed the presence of radionuclides and organics such as PCBs and mapped distributions of several inorganic elements. We summarized our findings in a series of peer-reviewed papers, two that were published in 1996 , two that were submitted for publication in 1996, and two additional articles that are currently undergoing review. In addition, Mr. Ted Christian completed his M.A. in Chemistry. His thesis addressed the analysis of polychlorinated biphenyls in honey bees collected from the INEEL, Montana, and Arizona. A 1996 article in the Journal of Environmental Quality covered the importance of INEEL facilities in relation to the deposition patterns of fluoride (F) to surrounding regions. The other articles address post-closure assessments of industrial facilities, radionuclides in bees and pollen sampled at the INEEL, heavy metal uptake by bees from several environmental media, and dispersal patterns for a variety of inorganic elements over the INEEL and surrounding regions. Although INEEL facilities emit a variety of contaminants, much of the impact is restricted to sites at the INEEL.
\end{abstract}

Keywords: Biomonitors, environmental surveillance, honey bees, PCBs.

\section{JUSTIFICATION}

After 40 years of conducting a wide array of activities, including the testing of nuclear materials for nation defense, the Department of Energy (DOE) has redirected its attention toward environmental stewardship. The goals are to bring DOE sites into compliance with environmental regulations and to reduce health and ecological risks by cleaning up contaminants. Environmental wastes often are contained (e.g., buried wastes) or follow well-defined drainage patterns, but if the sources or extent of contamination are unknown, costly sampling encompassing large regions may be required.

A more cost-effective solution is to use a mobile sampler that covers the area, samples all media, and returns to a fixed location. The honey bee meets these criteria and has proven to be an efficient multi-media monitor of contaminant dispersion (Bromenshenk et al. $1978,1985,1992,1995,1996)$. Both the National Research Council (1991) and the United States Environmental Protection Agency (EPA) (Warren-Hicks et al. 1989) have judged honey bees to be excellent monitors of air pollution and useful for in situ assessments of exposures of aerial, soil-, and water-borne contaminants, including any leakage from stored and buried wastes. This bee research was conducted at the Idaho National Engineering and Environmental Laboratory and off-site industrial facilities.

Much of this part of southeastern Idaho consists of basalt outcrops with few roads, sparsely distributed electrical power lines that could be used to run monitoring instruments, sparse vegetation, little water. The degree to which honey bees, especially small nucleus colonies, could withstand these harsh conditions and serve as useful, multi-media monitors of a wide array of pollutants was the subject of our INEEL studies.

We deployed bee colonies on the INEEL and sampled colonies at commercial beeyards in the area surrounding the INEEL--a total of 61 locations over four years. We compared these bees to those sampled (under EPA sponsorship) at 42 locations around a copper smelter in Montana and to bees at a federal facility in Maryland (under DOD

\footnotetext{
${ }^{17}$ Division of Biological Sciences, The University of Montana Missoula, Missoula, MT 59812

${ }^{18}$ Department of Chemistry, The University of Montana Missoula, Missoula, MT 58912
} 
sponsorship). Bees were analyzed for radionuclides, fluoride, other trace elements, including heavy metals, and organics such as pentachlorobiphenyls (PCBs). The data were processed using geostatistical procedures such as kriging (Bromenshenk et al. 1985), traditional statistical tests such as F- and Student's t-tests, and multivariate techniques such as a repeated measures discriminant analysis as a means of characterizing multiple chemical exposures and population response contaminant stress.

Exposures of bees to contaminants may result in a wide spectrum of pathological conditions, ranging from death to behavioral dysfunctions. Of particular interest to us are real-time changes in colony performance that can be monitored electronically and biochemical perturbations that can be assessed by diagnostic biomarkers, for example, the production of metallothioneins (Cronn 1991) or acetylcholinesterase (Bromenshenk 1978).

\section{Objectives}

Our overall objectives were to:

- Map chemical distributions from a variety of unique sources on a landscape scale.

- Compare levels of contaminants in bees to levels reported for other environmental samples.

- Contrast residue concentrations in bees from the INEEL with bees from other parts of the United States.

- Determine levels os specific biomarkers in INEEL bees versus bees from industrial areas in Montana.

- Evaluate the importance of INEEL facilities as contributors to regional deposition patterns of contaminants.
- Develop improved methods for real-time monitoring of chemical exposures and biological effects.

- Assess the feasibility of using bees as selfsustaining monitors in a semi-arid desert.

In 1996, our objectives were to complete publication of the results of our studies.

\section{PROJECT ACCOMPLISHMENTS}

- During 1996, two articles were accepted for publication, two were submitted for publication and two more completed.

- We also provided hands-on training to Foundation staff in the construction of Web pages.

\section{IMPORTANT RESULTS}

Bees from the INEEL and surrounding areas demonstrated accumulations of heavy metals and other inorganics that fell within the ranges observed at a Department of Defense site in Maryland. Although a few elements such as zinc exhibited some elevation at specific sites compared to reference sites in Montana and Maryland, overall levels of potentially toxic inorganic chemicals (with the exception of F) were considerably lower than those observed for bees from industrial regions.

\section{PRODUCTS}

Our 1996 products and their status includes the following technical reports:

Bromenshenk, J. J., R. C. Cronn, and J. J. Nugent. 1996. Monitoring fluoride with honey bees in the upper Snake River Plain of Idaho. Journal of Environmental Quality 25: 868-877. 
Christian, T. J. 1996. Analysis of polychlorinated biphenyls in honey bees. M.S. Thesis. The University of Montana, Missoula. $60 \mathrm{pp}$.

Bromenshenk, J. J., J. L. Gudatis, and R. C. Cronn. In press. Post-closure assessments of industrial complexes with honey bees. Environmental Contamination and Toxicology.

Cronn, R. C., and J. J. Bromenshenk. In press. Radionuclide accumulation in honey bees at the Idaho National Engineering Laboratory. Journal of Environmental Quality.

Bromenshenk, J. J., J. L. Gudatis, and R. C. Cronn. Submitted. Heavy metal uptake in honey bees. Environmental Monitoring and Assessment.

Bromenshenk, J. J., R. C. Cronn, J. J. Nugent, J. L. Gudatis, and R. L. McGraw. Submitted. Dispersal of inorganic contaminants in the upper Snake River Plain of Idaho. Apidologie.

\section{LITERATURE CITED}

Bromenshenk, J. J. 1978. Entomological studies in the vicinity of Colstrip, Montana. Pages 140-212 in E.M. Preston and R.A. Lewis, eds. The bioenvironmental impact of a coal-fired power plant, Third interim report, Colstrip, Montana. Volume 5. EPA-600/3-78-021. U.S. Environmental Protection Agency, Corvallis Environmental Research Laboratory, Corvallis, Oregon.
Bromenshenk, J. J., S. R. Carson, J. C. Simpson, and J. M. Thomas. 1985. Pollution monitoring in Puget Sound with honey bees. Science 227:632-634.

Bromenshenk, J. J. 1992. Site-specific and regional monitoring with honey bees: case study comparisons. Pages 689-704 in D.H. McKenzie, D. E. Hyatt, and V. J.

McDonald, eds. Ecological Indicators. Elsevier Applied Science, London and New York.

Bromenshenk, J. J., G. C. Smith, and V. J. Watson. 1995. Assessing ecological risks in terrestrial systems with honey Bees. Pages 9-30 in F. M. Butterworth, L. D. Corkum, and J. Guzmán-Rincón, eds., Biomonitors and Biomarkers as Indicators of Environmental Change. Plenum Press, New York, NY.

Bromenshenk, J. J., R. C. Cronn, and J. J. Nugent. 1996. Monitoring fluoride with honey bees in the upper Snake River Plain of Idaho. Journal of Environmental Quality 25:868-877.

Cronn, R. C. 1991. Determination of cadmium toxicity and the relationship between dose and metallothionein levels in the honey bee, Apis mellifera. M.S. Thesis. The University of Montana, Missoula.

National Research Council. 1991. Animals as Sentinels of Environmental Health Hazards. National Academy Press, Washington D.C. 160 pp.

Warren-Hicks, W., B. R. Parkhurst, and S. S. Baker, Jr. 1989. Ecological assessments of hazardous waste sites: A field and laboratory reference document. U.S. Environmental Protection Agency, Corvallis Environmental Research Laboratory, Corvallis OR, EPA 600/3-89/013. 


\author{
William H. Clark ${ }^{19}$ and Paul E. Blom ${ }^{20}$
}

\begin{abstract}
Early work identified 22 species of ants at the Idaho National Engineering and Environmental Laboratory (INEEL). Our assessment of the ants of the INEEL reveals that there are twice that many species (43). Our research has reported five species from Idaho for the first time: Liometopum luctuosum, Camponotus hyatti, Formica gynocrates, Formica montana, and an undescribed species of Myrmica. To build a baseline understanding of the INEEL ant fauna, its diversity, and abundance, we produced a checklist of the ants of the INEEL, which can be used in various waste management and ecological investigations. We continued curating historical collections by pinning and labeling hundreds of ant specimens. We worked with various experts to identify and verify some of the ant specimens collected. We collected a few additional specimens at the INEEL during 1996. We continued computerizing the data by constructing database programs and by entering several thousand ant specimens. A poster about the project is currently on display at the Orma J. Smith Museum of Natural History, Albertson College of Idaho, and is viewed by thousands of visitors annually. Three additional presentations were made describing the results of the project. At least three scientific publications are in preparation and nearing completion. Several presentations have been made resulting from this project. Twenty seven publications concerning the ant fauna of INEEL have been published since the original 1971 list. Of those, 23 are the result of current research of Clark and Blom.
\end{abstract}

Keywords: Biodiversity, ant fauna, entomological curation, Liometopum luctuosum, Camponotus hyatti, Formica gynocrates, Formica montana, Myrmica sp. nov., insect waste intrusion.

\section{JUSTIFICATION}

Ants are an important and ubiquitous component of the semi-arid land ecosystem where their biomass can exceed the collective biomass of all vertebrates. They contribute to soil processes and energy cycling. Some species can significantly alter soil moisture and water infiltration characteristics, and can unearth buried wastes and contaminated soils. Others can change vegetation patterns and thereby affect hazardous waste storage areas. Knowledge of the species composition and distribution over an area is important for long-term waste management decisions, as well as comprehensive land stewardship.

We have collected ants at the INEEL since 1986 to update and complete the original list of ants of the site (Allred 1968, Allred and Cole 1971). Many important contributions were made during this time. Our current work continues curation, data entry, and checklist preparation.

\section{Objectives}

The 1996 objectives of this project's work plan were to:

- Perform final spot checks and minor project follow up initiated by 1994-95 field work.

- Complete ant specimen curation and identification.

- Deposit voucher specimens.

- Finalize the checklist and submit to a scientific journal for publication.

\section{PROJECT ACCOMPLISHMENTS}

- Final spot checks were completed during July when Clark assisted the scientists from the University of Texas, El Paso with some ant work.

\footnotetext{
${ }^{19}$ Albertson College of Idaho, Caldwell, ID.

${ }^{20}$ Pennsylvania State University, State College, PA.
} 
A few additional collections were made. These consisted mainly of alate Pogonomyrmex salinus, guests of Pogonomyrmex salinus, and Lasius. Clark was also able to revisit major study sites at INEEL and complete obtaining GPS locations and photographs from these locations.

- We made substantial progress toward completing identification and curation of specimens and we will complete it as time is available.

Thousands of field vials of ants were sorted, many of these were from the summer 1994 burn project; more than 2,000 individual ant specimens were pinned and labeled. All ants collected during 1995 were curated. Ants pinned and labeled to date were placed into the Museum collection.

- We began curating historical INEEL collections.

This means that the backlog of pinned ants was labeled and placed correctly into the collection. Now, nearly all of the 1,150 nest collections by Clark are curated. Most of the specimens have been entered onto the Museum database.

As mentioned, ant and invertebrate specimen data collected during 1996 and previous years are in the process of being computerized. Much of this work is finished, but it will continue on a volunteer basis. The application used for cataloging the specimens permits storing individual counts and preserves sample identity. Such a database ultimately facilitates extraction of the data for distribution and ecological analyses.

- We received the ant species verifications and determinations from Dr. Andre Francoeur for Formica, Myrmica, and Aphaenogaster.

This gave a large boost to the project. We have some identifications yet to make with this newly acquired reference material. Dr. William P. MacKay determined our specimens of Camponotus subgenus Myrmentoma.

- A set of voucher specimens has been deposited in the entomological collections at the Orma J. Smith Museum of Natural History, Albertson College of Idaho, Caldwell (CIDA) and with individual taxonomic specialists who are working on the material.

When curation is complete a set of voucher specimens will be deposited in the William F. Barr Entomological Museum, University of Idaho, Moscow. Thus, they will both document the present research and be readily available to the scientific community for future studies.

- Finalization of the checklist and submission for publication is currently in progress.

- A poster (Blom et al. 1991a) showing some aspects of this project is on display at the Orma J. Smith Museum of Natural History.

The poster is viewed by thousands of students and other Museum visitors annually. Presentations on the project were made at Albertson College of Idaho and Pennsylvania State University during 1996.

\section{INIPORTANT RESULTS}

Blom showed that harvester ant burrowing is an important consideration in waste burial (Blom 1990, Blom et al. 1991b). As these studies focused on one species, Pogonomyrmex salinus, there is a great need for adequate knowledge about the habits and ecology of the other ant species on the INEEL. By doubling the known number of 
ant species on the INEEL and expanding the collections of other invertebrates, this project has shown other species of ants are present and should be considered in planning and implementing DOE environmental restoration and waste management activities.

Our research has reported five species from Idaho for the first time: Liometopum luctuosum, Camponotus hyatti, Formica gynocrates, Formica montana, and an undescribed species of Myrmica (Jackson et al. 1991).

A museum specimen-level data management system was implemented for accession and vouching of the INEEL invertebrate samples. Thus, knowledge about these arthropods and their ecological roles is available for management decisions.

\section{PRODUCTS}

We made additional progress on three papers resulting from this project:

- Clark, W. H., P. E. Blom, and P. J. Johnson. Final Draft. Gonasida elata LeConte associated with Pogonomyrmex salinus Olsen nest soils in southeastern Idaho (Coleoptera, Tenebrionidae, Asidinae; Hymenoptera, Formicidae, Myrmicinae). Proceedings of the Entomological Society of Washington.

- Blom, P. E., D. A. Schoep, and W. H. Clark. Revised Draft. Observations of cicada nymphs, Okanagana annulata Davis (Homoptera: Cicadidae) and the harvester ant Pogonomyrmex salinus Olsen (Hymenoptera, Formicidae) in southeastern Idaho. Great Basin Naturalist.

- Clark, W. H., and P. E. Blom. Second Draft. Bibliography of the harvester ant genus Pogonomyrmex. Outlet to be determined.

\section{ACKNOWLEDGMENTS}

We thank Cindy, Mary, and Ellen Clark, Jim and Katharine Pike, and Rob Gerber for assistance with specimen curation and data entry. Andre Francoeur and William MacKay assisted with the identification of ant specimens.

\section{LITERATURE CITED}

Allred, D. M. 1968. Ticks of the National Reactor Testing Station. Brigham Young University Science Bulletin, Biological Series 10:1-29.

Allred, D. M., and A. C. Cole, Jr. 1971. Ants of the National Reactor Testing Station. Great Basin Naturalist 31:237-242.

Blom, P. E. 1990. Potential impacts on radioactive waste disposal situations by the harvester ant, Pogonomyrmex salinus Olsen (Hymenoptera: Formicidae). Unpublished M.S. thesis, University of Idaho, Moscow, Idaho. $241 \mathrm{pp}$.

Blom, P. E., W. H. Clark, P. J. Johnson, and J. B. Johnson. 1991a. Observations of several insect species exploiting soils associated with the harvester ant, Pogonomyrmex salinus. Idaho Academy of Science, 34th Annual Meeting, March 26-28, 1992, Caldwell, Idaho. Journal of the Idaho Academy Science 28:14.

Blom, P. E., J. B. Johnson, and S. Rope. 1991b. Concentrations of ${ }^{137} \mathrm{Cs}$ and ${ }^{60} \mathrm{Co}$ in nests of the harvester ant, Pogonomyrmex salinus, and associated soils near nuclear reactor waste water disposal ponds. American Midland Naturalist 126:140-151.

Jackson, B. D., S. J. Keegans, E. D. Morgan, W. H. Clark, and P. E. Blom. 1991. Chemotaxonomic study of a new species of Myrmica ant (Hymenoptera:

Formicidae) from Idaho. Journal of Chemical Ecology 17:335-342. 


\title{
RADIONUCLIDE CYCLING IN PLASTIC LINED EVAPORATION PONDS AND EFFECTS ON RADIONUCLIDE LEVELS IN AND RADIATION DOSES TO WATERFOWL AND WATERFOWL HUNTERS
}

\author{
Ronald W. Warren ${ }^{21}$
}

\begin{abstract}
Research is being conducted to determine the fate of radionuclides released as liquid effluent to two double-lined evaporation ponds at the Test Reactor Area on the INEEL. In order to determine the fate of radionuclides at the TRA ponds, it is necessary to quantify all inputs to, and losses from, those systems. Emphasis was placed on determining potential radionuclide transport from the ponds, especially transport to humans via waterfowl which have spent time on the ponds. During 1996, 112 samples were taken to quantify radionuclide concentrations in the pond components and in avian species potentially transporting radionuclides from the ponds. A total of 317 analyses were conducted on those samples. Between August, 1994 and May, 1996, total radionuclide concentrations in the water column increased by a factor of three to four. The total concentration in the water column was about $2.0 \mathrm{nCi} / \mathrm{ml}$, of which 97 to $99 \%$ was tritium. Concentrations of ${ }^{54} \mathrm{Mn}$ and ${ }^{60} \mathrm{Co}$ in filtered water were lower than those in the formerly used TRA percolation ponds by average factors of 20 and 6.2, respectively. Yet, evaporation pond sediments had ${ }^{54} \mathrm{Mn}$ and ${ }^{60} \mathrm{Co}$ concentrations about 1.7 times higher than those measured in the old percolation ponds. On each of 84 daily visits during 1996, the number and species of birds using the ponds and the number of tumbleweeds in the ponds were recorded. Analysis of day-long pond observations was completed. There were a total of 30 bird species observed using the ponds during 1996, of which 12 were waterfowl. Of 82 waterfowl visits recorded during the long-term observations, the duration of 52 visits were known to within $0.5 \mathrm{~h}$. Of these, $75 \%$ were less than one hour, $15 \%$ were between one and two hours, $2 \%$ were between two and three hours, $4 \%$ were between five and six hours, and $4 \%$ were between 11 and 12 hours long. Based on daily surveys, the median potential maximum waterfowl visit time was $1 \mathrm{~d}$. Analysis of data from 30 ducks collected over the period of this study, showed total concentrations in the edible portion to average $3.4 \mathrm{pCi} \mathrm{g}^{-1}$ in control ducks, $8.2 \mathrm{pCi} \mathrm{g}^{-1}$ in ducks collected from TRA, $4.8 \mathrm{pCi} \mathrm{g}^{-1}$ in ducks collected from TAN, $2.7 \mathrm{pCi} \mathrm{g}^{-1}$ in ducks collected from ICPP, and $2.5 \mathrm{pCi} \mathrm{g}^{-1}$ in ducks collected from ANL-W. The whole body committed effective dose from eating $225 \mathrm{~g}$ of meat averaged $0.14,0.4,0.3,0.17$, and $0.13 \mu \mathrm{Sv}$, for control, TRA, TAN, ICPP, and ANL-W ducks, respectively. All barn swallows and three of 13 mourning doves showed higher-thanbackground concentrations of radionuclides. The total average concentration found in tumbleweed samples was 4.3 $\mathrm{nCi} \mathrm{g}^{-1}$. The potential amount of activity transported from the ponds by tumbleweeds was estimated to be $0.8 \mathrm{mCi}$ between January 1, 1994, and December 31, 1996. Most tumbleweeds accumulate in an approximately 32 ha (79 acres) area, about $470 \mathrm{~m}(1,500 \mathrm{ft})$ to the northeast of the ponds. Average exposure rates increased from $1.5 \mathrm{mR} \mathrm{d}^{-1}$ on the shore of the ponds during the third quarter of 1994 , to $9.1 \mathrm{mR} \mathrm{d}^{-1}$ on the east pond and $13.5 \mathrm{mR} \mathrm{d}^{-1}$ on the west pond by the end of 1996.
\end{abstract}

Keywords: Ponds, radionuclides, Test Reactor Area, waterfowl.

\section{JUSTIFICATION}

Two lined ponds were constructed during the summer of 1993 to replace percolation ponds at the Test Reactor Area (TRA). Many studies were conducted over the lifetime of the percolation ponds (Morris 1994) and much was learned about radionuclide cycling in, and transport from such ponds. Radionuclides tended to become bound with the sediments of the percolation ponds (Ibrahim and Culp 1989, Millard 1986) such that the potential for transport of large amounts of radioactivity was limited and the potential for doses to humans was consequently small. In contrast, little is known about radionuclide cycling in a lined-pond system. With very little sediment present, at least initially, radionuclide behavior is likely different than in a non-lined percolation pond. Without sediment, radionuclides may be more available (i.e. in the water column) to waterfowl and other birds, thereby increasing the likelihood of transport of contaminants from the pond and potentially to humans. Also, radionuclides remaining in the water column will have less shielding and, thus, may result in higher

\footnotetext{
${ }^{21}$ Environmental Science and Research Foundation, P.O. Box 51838, Idaho Falls, ID 83405-1838.
} 
exposure rates on and around the ponds.

Because the central concept in hazardous waste management is to keep waste isolated from the environment and humans, the question of whether lined-pond systems have a greater potential for environmental exposure than percolation ponds must be answered.

Understanding the behavior of radionuclides in a lined-pond system is also important for other reasons. The environmental assessment for the lined ponds (U.S. Department of Energy 1991) indicated that studies of waterfowl using the pond be initiated to determine whether they constitute a significant pathway of contaminants to humans. Second, because waterfowl are protected under The Migratory Bird Treaty Act, information on the effects of contamination on waterfowl in lined ponds is needed. These data can also be used in support of Ecological Risk Assessment. The analysis of the potential radiation dose to humans from migrating waterfowl will be included in the Annual Site Environmental Report as mandated by DOE Order 5400 .

\section{Objectives}

In order to determine the fate of radionuclides in lined ponds, this project has the following objectives:

- Determine the potential for transport of radioactive contamination off-site by waterfowl which use the lined ponds and the potential for radiation dose to humans from eating them.

- Determine the transport of radionuclides from the ponds by vectors other than waterfowl, specifically mourning doves, barn swallows, and tumbleweeds.

- Determine radionuclide cycling in the ponds through time.

- Create a dynamic model of radionuclide cycling in the pond system to be used to estimate future potential radiation doses to waterfowl and humans.

- Compare these results with the potential for dose to waterfowl and humans determined for the previously used percolation pond system.

\section{PROJECT ACCOMPLISHMENTS}

Major project accomplishments for 1996 included:

- Observation data were collected throughout the year to determine visitation rates and residence times for waterfowl.

Eighty-four daily visits were made at random times during 1996. On each visit the number and species of birds using the ponds were recorded. Analysis of day-long pond observations was completed.

- Sample collection of pond components.

Both evaporation ponds were sampled in January, March, April, May, September, and October. No samples were taken from the ponds June through August because of denied access by LMITCO. Ducks were collected in April, May, October, November, and December. Swallows and mourning doves were collected in August and September. During 1996, 112 samples were taken to quantify radionuclide concentrations in the pond components and in avian species potentially transporting radionuclides from the ponds. Of the samples, 26 were water, 20 were sediment, 24 were seston, 4 were vegetation, 17 were mourning doves, 8 were barn swallows, and 13 were ducks. In addition, 90 tumbleweeds ( 30 each of three species) were collected from control areas and placed into the ponds for increasing time periods to quantify the sorption of radionuclides to tumbleweeds over time.

Of the 13 ducks collected, four were taken 
from the TRA ponds and three were collected as controls (one from the Ft. Hall area and two from the south fork of the Snake River near Heise). A total of six ducks were collected from ponds at TAN and ICPP and will be used for comparison purposes. Data from ducks collected in 1995 and the spring of 1996 were analyzed. Thirteen mourning doves were collected from the evaporation pond area and four control mourning doves were collected near Rigby, ID. Five barn swallows were collected near the evaporation ponds and three control barn swallows were collected from an area $11 \mathrm{~km}(6 \mathrm{mi})$ north of Idaho Falls.

- Samples of pond components were analyzed for gamma-emitting radionuclides. A subset was analyzed for strontium and transuranics (all water samples were also analyzed for tritium).

- A total of 317 analyses were conducted on the pond component and avian samples.

- The number of tumbleweeds in the ponds were recorded on daily surveys. An experiment was conducted to determine how far tumbleweeds traveled from the pond area.

- Eight dosimeters were maintained around the ponds through 1996. Each of these was replaced quarterly. These data will be used to calculate doses to birds spending time at various locations on the ponds.

- Water quality measurements including $\mathrm{pH}$, conductivity, temperature and dissolved oxygen were taken at multiple times through the year.

\section{IMPORTANT RESULTS}

There were three bird species observed using the ponds which had not been observed previously on the ponds. These were an American kestrel, horned grebe, and least sandpiper. There were a total of $30 \mathrm{bird}$ species observed using the ponds during 1996, of which 12 were waterfowl. The total number of bird species observed using the ponds over the entire study thus far is 69 , of which 26 were waterfowl species. According to research conducted from April 1989 through October 1991 (Cieminski 1993), a total of 68 species of birds were observed at the, now reclaimed, TRA percolation ponds. Our data indicate that, in regard to bird species richness, the TRA evaporation ponds rank fourth out of 22 waste ponds on the INEEL. Over the entire study, bird surveys have been conducted on the evaporation ponds on 335 days. In 1996, bird surveys were also conducted on the newly constructed sewage ponds, located about $75 \mathrm{~m}(248 \mathrm{ft})$ north of the evaporation ponds, and on the ICPP percolation ponds due to the interchange of birds between all of these ponds. The ICPP ponds were surveyed 19 times and the TRA sewage ponds were surveyed 27 times during 1996. The number of birds observed per survey was $2.4,3.9,3.8$, and 46.0 on the west evaporation pond, east evaporation pond, ICPP percolation pond, and TRA sewage pond, respectively. Though more birds are clearly using the TRA sewage ponds compared with the evaporation and ICPP ponds, the very high number for the sewage pond is more a result of surveys being conducted only during peak migration periods. Future surveys will be conducted on the same days for all ponds to remedy this bias. The number of waterfowl observed per survey (waterfowl/survey) peaked at 2.0 in 1994 for the west evaporation pond and decreased to 0.5 in 1995 and to 0.3 in 1996.

The waterfowl/survey for the east evaporation pond increased in each year of the study from 
1.2 in 1993 to 1.85 in 1996 . The reason for these differences is not known at this time.

Day-long observation data collected in 1995 were analyzed. A total of 82 individual waterfowl visits were recorded. Of the duration of those visits, 52 were known to within $0.5 \mathrm{~h}$, seven were known to within 2 to $3.5 \mathrm{hrs}$, nine were known to within $9 \mathrm{~h}$, and 14 were known to be greater that 7,11 , and 16 $h$. Of the visit durations that were known to within $0.5 \mathrm{~h}, 75 \%$ were less than one hour, $15 \%$ were between one and two hours, $2 \%$ were between two and three hours, $4 \%$ were between five and six hours, and $4 \%$ were between 11 and 12 hours long. Potential maximum visit durations were estimated using daily survey data and the assumption that if the same species and number of individuals were observed on two or more consecutive survey days, they were the same birds. There were 33 instances when one or more birds of the same species were observed on the ponds. A total of 72 waterfowl were observed in these 33 instances. Both the median and mode potential maximum visit duration was one day. The observed range was one to eight days.

Between August, 1994, and May, 1996, total radionuclide concentrations in the water column have increased by a factor of about three on the west pond and about four on the east pond (Fig. 23, Fig. 24). As of May, 1996 , the total concentration in the water column was about $2.0 \mathrm{nCi} / \mathrm{ml}$. Over $97 \%$ of this in the west pond, and $99 \%$ of it in the east pond, was from tritium. Concentrations of some of the major radionuclides in filtered water, seston, and sediment are listed in Table 13. Concentrations of ${ }^{54} \mathrm{Mn}$ and ${ }^{60} \mathrm{Co}$ in filtered water in the evaporation ponds were lower than those in the old percolation ponds by average factors of 20 and 6.2 , respectively. Yet, evaporation pond sediments had ${ }^{54} \mathrm{Mn}$ and ${ }^{60} \mathrm{Co}$ concentrations about 1.7 times higher than those measured in the old percolation ponds.

Data from a total of 30 ducks collected over the period of this study, three of which were collected in 1996, have been partially analyzed. Total radionuclide concentrations in the edible portion and the whole body committed effective dose to a human from eating $225 \mathrm{~g}$ of meat from these ducks are listed in Table 14. Higher average concentrations were found in ducks collected from the TRA evaporation ponds and the TAN TSF pond due mainly to three ducks, two from TRA and one from TAN (Fig. 25). Concentrations in the edible portion of the two higher-than-background ducks from TRA were 32.9 and $12.6 \mathrm{pCi} \mathrm{g}^{-1}$ while the average of the remaining six ducks taken from TRA averaged $3.3 \mathrm{pCi} \mathrm{g}^{-1}$. Concentrations in the edible portion of the higher-than-background duck from TAN was $7.1 \mathrm{pCi} \mathrm{g}^{-1}$ verses an average of $3.6 \mathrm{pCi} \mathrm{g}^{-1}$ for the remaining two from TAN. Average external (skin and feathers) concentrations appeared elevated in ducks from TRA and TAN. External portions of all ducks from TRA showed elevated levels of ${ }^{60} \mathrm{Co}$ (average $=9.0 \mathrm{pCi} \mathrm{g}$ ), and ${ }^{137} \mathrm{Cs}$ concentrations were elevated for at least two ducks from TRA and for all three ducks from TAN. Research conducted 1974 through 1978 by Halford et. al (1981) estimated the potential whole body committed dose from eating an average duck from the formerly used TRA percolation ponds to be about 110 $\mu \mathrm{Sv}(11 \mathrm{mrem})$, a factor of 300 times higher than that from an average duck taken from TRA over the past two years.

All five barn swallows collected from TRA had higher total concentrations than control samples. The average concentration in TRA barn swallow samples was $12.1 \mathrm{pCi}^{-1}$ (wet weight) with a range of 4.4 to $25.7 \mathrm{pCi} \mathrm{g}^{-1}$. The average concentration in control barn swallow samples was $2.4 \mathrm{pCi} \mathrm{g}^{-1}$. Previous research conducted in the late 1970 s by Millard et. al (1990) showed average concentrations in adult barn swallows taken at TRA to be about $1,380 \mathrm{pCi} \mathrm{g}^{-1}$, a factor of about 54 to 314 times higher than those observed in 1996. 

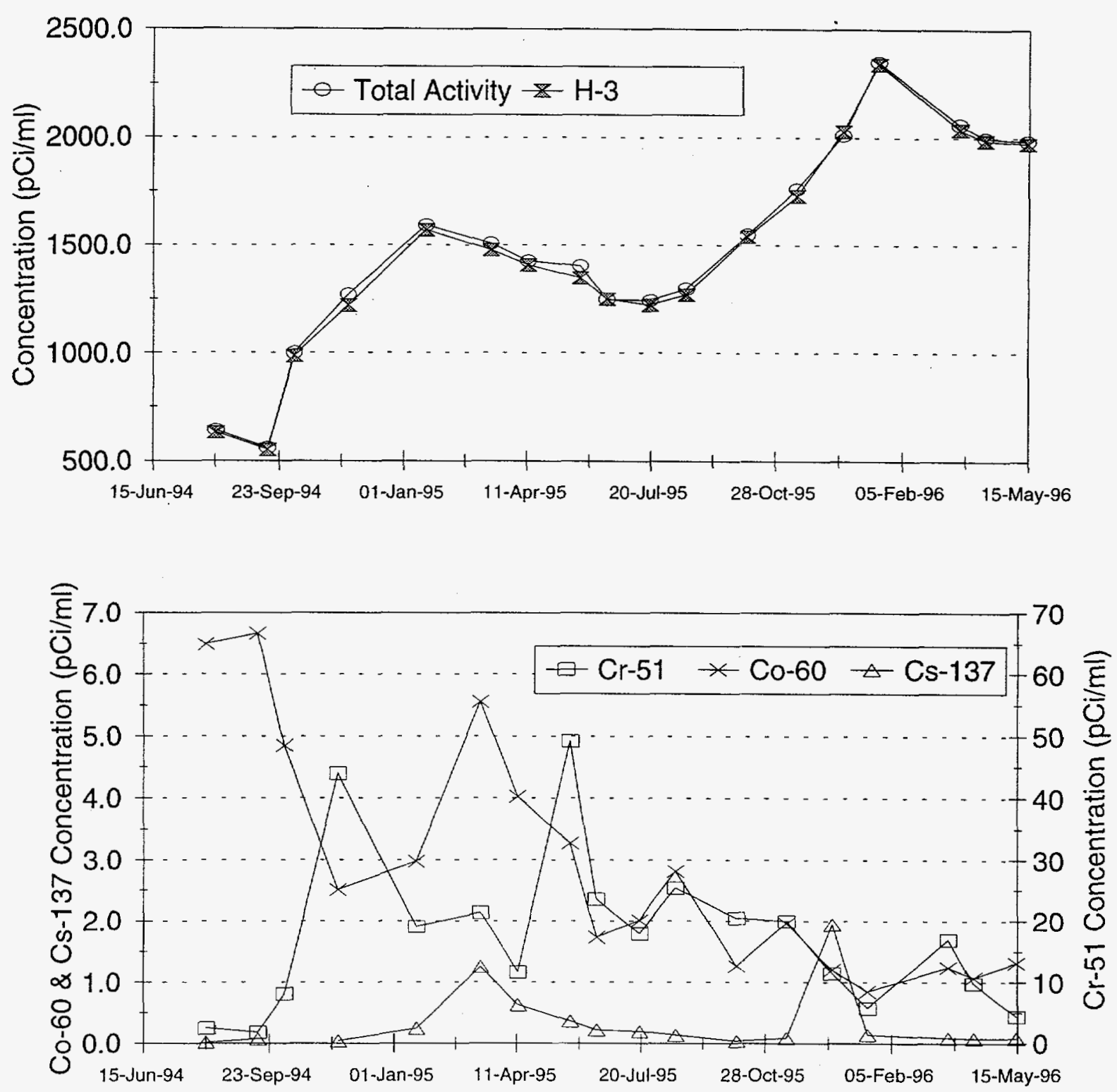

Fig. 23. Total and major radionuclide concentrations in the water column of the east evaporation pond at the Test Reactor Area. 

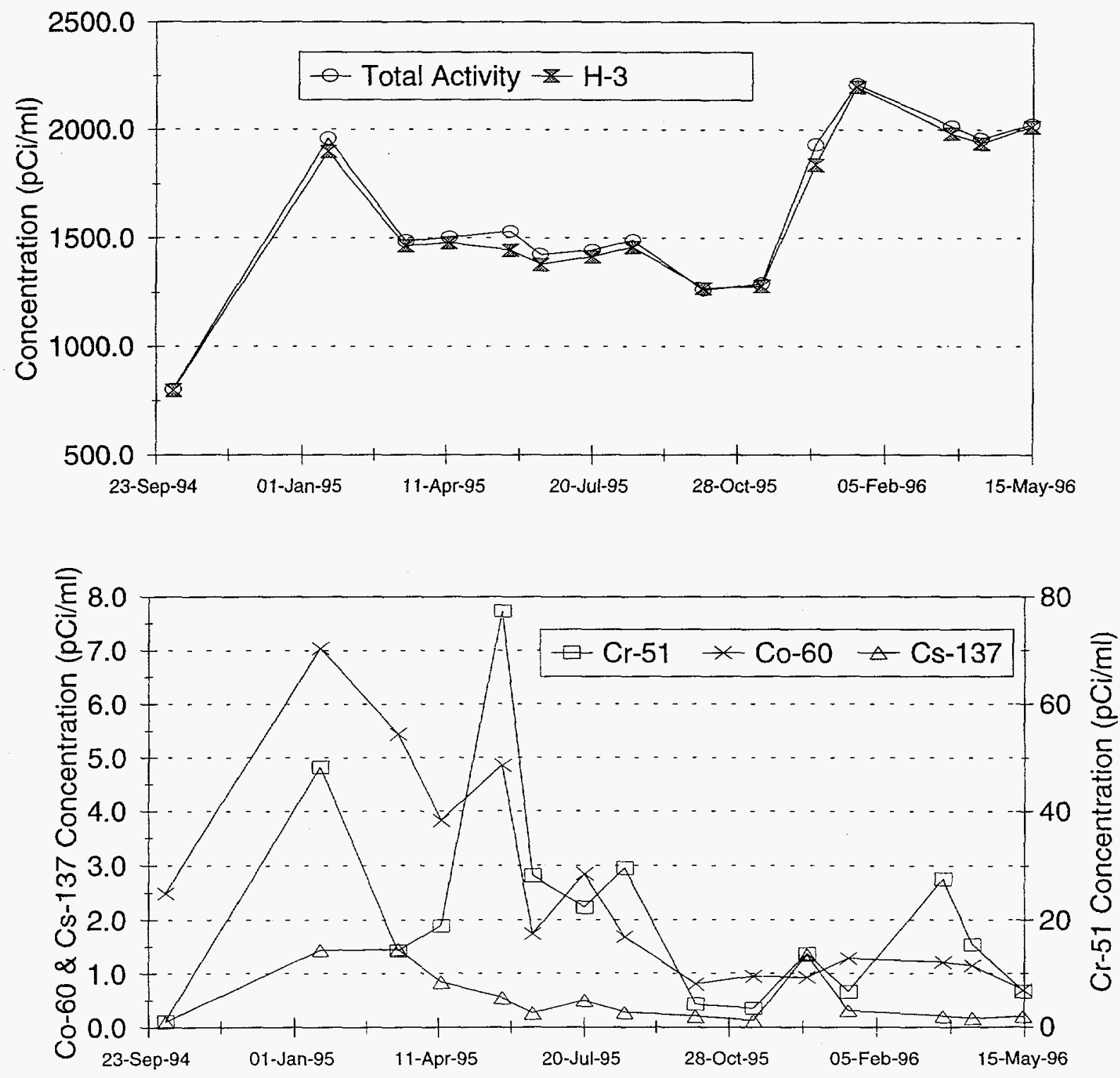

Fig. 24. Total and major radionuclide concentrations in the water column of the west evaporation pond at the Test Reactor Area. 
Table 13. Concentrations of selected radionuclides in filtered water, seston (particulate matter), and sediment from the lined evaporation ponds and the formerly used percolation ponds at TRA.

Average Concentration

$\left(\mathrm{pCi} \mathrm{g}^{-1}\right)$

\begin{tabular}{|c|c|c|c|c|c|c|}
\hline \multirow[b]{2}{*}{ Radionuclide } & \multicolumn{3}{|c|}{ Lined Ponds } & \multicolumn{3}{|c|}{ Percolation Ponds } \\
\hline & $\begin{array}{c}\text { Filtered } \\
\text { Water }\end{array}$ & Seston & Sediment & $\begin{array}{c}\text { Filtered } \\
\text { Water }\end{array}$ & Seston & Sediment \\
\hline${ }^{51} \mathrm{Cr}$ & 8.4 & 13.8 & 2,600 & 2500 & $4.6 \times 10^{7}$ & 12,000 \\
\hline${ }^{54} \mathrm{Mn}$ & 0.01 & 0.02 & 270 & 0.2 & $1.2 \times 10^{5}$ & 150 \\
\hline${ }^{60} \mathrm{Co}$ & 1.0 & 1.4 & 51,000 & 6.2 & $1.1 \times 10^{6}$ & 32,000 \\
\hline${ }^{65} \mathrm{Zn}$ & 0.003 & 0.08 & 140 & 0.6 & $2.0 \times 10^{5}$ & 690 \\
\hline${ }^{137} \mathrm{Cs}$ & 0.27 & 0.19 & 3,000 & 2.8 & $2.7 \times 10^{5}$ & 28,000 \\
\hline${ }^{90} \mathrm{Sr}$ & 0.91 & 0.1 & 900 & NM & NM & NM \\
\hline
\end{tabular}

$\mathrm{NM}=$ not measured

Of the 13 mourning doves collected from TRA, three had elevated total concentrations of $7.0,8.4$, and $11.2 \mathrm{pCi} \mathrm{g}^{-1}$ (wet weight) in the edible portions. The remaining 10 mourning doves from TRA and four control samples had average total concentrations of 2.5 and $3.3 \mathrm{pCi} \mathrm{g}^{-1}$, respectively. Markham and Halford (1982) reported the highest concentration in muscle tissue from a mourning dove collected at TRA to be 171 $\mathrm{pCi} \mathrm{g}^{-1}$, a factor of about 15 times higher than the maximum observed in 1996.

The average total concentration found in the tumbleweed samples was $4.3 \pm 0.4 \mathrm{nCi}$ $\mathrm{g}^{-1}(\mathrm{n}=23)$. Between October 18, 1994, and November 8,1996 , surveys were conducted on 206 days to observe birds and count tumbleweeds in the ponds. Numbers of tumbleweeds found in the ponds were highly variable. An average of 11 (Standard Deviation $=26$ ) tumbleweeds were observed in the west evaporation pond and an average of 43 (Standard Deviation $=77$ ) tumbleweeds were observed in east evaporation pond on survey days. Based on changes in tumbleweed numbers between survey days, it is estimated that a total of about 6500 tumbleweed have blown into and out of the ponds between January 1, 1994 and December 31, 1996. Based on the observed average concentrations in tumbleweeds from the ponds, the number of tumbleweeds moving from the ponds, and the average weight of tumbleweeds in the area being 28.7 $\mathrm{g}$ (Standard Deviation $=35.7, \mathrm{n}=181$ ), the potential amount of activity transported from the ponds is estimated to be about $0.8 \mathrm{mCi}$ between January 1, 1994, and December 31, 1996. An experiment was conducted to determine the dispersion distances of tumbleweeds from the evaporation pond area. Ninety tumbleweeds ( 30 each of three species) were taken from control areas, dried, measured, weighed, marked, and released near the evaporation ponds on March 28, 1996. Between March 28, 1996 and June 13, 1996, marked tumbleweeds were relocated five times. Travel distances for Russian thistle (Salsola kali) and Jim Hill mustard (Sisymbrium altissimum) were not significantly different $(\mathrm{p}=0.07)$ at an average of $339 \mathrm{~m}$ (Standard Deviation $=123 \mathrm{~m}$ ), while 
Table 14. Average total concentrations of radionuclides in the edible portion of ducks collected from waste ponds on the INEEL and the whole body committed effective dose to a human from eating $225 \mathrm{~g}$ of meat from these ducks.

\begin{tabular}{lccc}
\hline Collection Location & $\begin{array}{c}\text { Concentration } \\
\left(\mathrm{pCi} \mathrm{g}^{-1} \text { wet weight }\right)\end{array}$ & $\begin{array}{c}\text { Dose } \\
(\mu \mathrm{Sv})\end{array}$ & Number of Samples \\
\hline Control Locations & 3.4 & 0.14 & 12 \\
TRA Evaporation Ponds & 8.2 & 0.4 & 8 \\
TAN TSF Pond & 4.8 & 0.3 & 3 \\
ICPP Perc. Pond & 2.7 & 0.17 & 3 \\
ANL-W Sewage Ponds & 2.5 & 0.13 & 3 \\
\hline
\end{tabular}

summer cypress (Kochia scoparia) had an average travel distance of $239 \mathrm{~m}$ (Standard Deviation $=139 \mathrm{~m}$ ). All tumbleweeds traveled in the predominant wind direction, towards the northeast, and all remained within an area 32 ha (79 acres) in size. Also in 1996, an experiment was conducted to quantify radionuclide sorption to tumbleweeds immersed in the evaporation ponds for varying time periods but data from this experiment have yet to be analyzed.

Exposure rates around the evaporation ponds have generally increased every quarter throughout the study, with a marked increase during the second and third quarter of 1996. Average exposure rates averaged 1.4 (Standard Deviation $=0.2$ ) $\mathrm{mR} \mathrm{d}^{-1}$ on the shore of the east pond and 1.6 (Standard

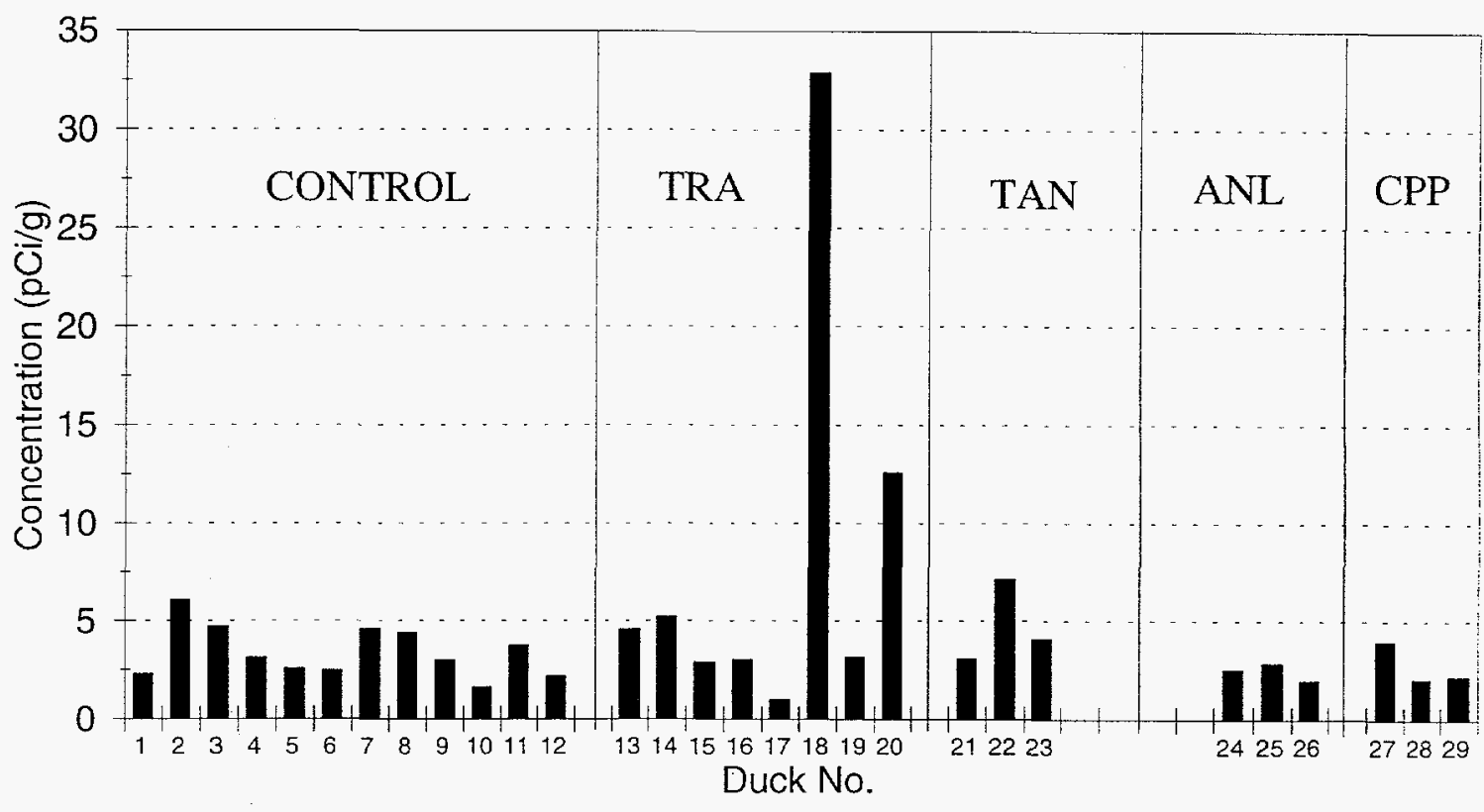

Fig. 25. Total radionuclide concentrations in the muscle tissue of both control ducks and ducks using waste ponds on the INEEL. Ducks were collected in both 1995 and 1996. 
Deviation $=0.2) \mathrm{mR} \mathrm{d}^{-1}$ on the shore of the west pond during the third quarter of 1994. By the first quarter of 1996, exposure rates on the shore averaged 4.8 (Standard Deviation $=$ 2.6) and 5.5 (Standard Deviation $=1.1) \mathrm{mR}$ $\mathrm{d}^{-1}$ on the east and west ponds, respectively. Average exposure rates on the shore increased to 9.1 (Standard Deviation $=0.6$ ) $\mathrm{mR} \mathrm{d}^{-1}$ on the east pond and to 13.5 (Standard Deviation $=1.0) \mathrm{mR} \mathrm{d}^{-1}$ on the west pond over the second, third, and fourth quarters of 1996. The reason for the considerable increase in 1996 is not known at this time.

\section{PRODUCTS}

An abstract entitled, "Sorption and Transport of Radionuclides by Tumbleweeds from Two Plastic-Lined Evaporation Ponds," was prepared and submitted to the national Health Physics Society for presentation at the 42nd annual meeting to be held in San Antonio, TX, in late June, 1997. An outline has been prepared for the final report of this study to be completed by October 31, 1997. Chapters of the final report will be submitted for publication in peer reviewed journals.

\section{LITERATURE CITED}

Cieminski, K. L. 1993. Wildlife use of wastewater ponds at the Idaho National Engineering Laboratory. M.S. thesis, South Dakota State University, Brookings. $311 \mathrm{pp}$.

Halford, D. K., J. B. Millard, and O. D.

Markham. 1981. Radionuclide concentrations in waterfowl using a liquid radioactive waste disposal area and the potential radiation dose to man. Health Physics 40:173-181.

Ibrahim, S., and T. Culp. 1989. Plutonium distribution and oxidation states in a reactor leaching pond system. Health Physics 57:607-614.

Markham, O. D., and D. K. Halford. 1982. Radionuclides in mourning doves near a nuclear facility complex in southeastern Idaho. Wilson Bulletin 94(2):185-197.

McCuen, R. H. 1989. Hydrologic analysis and design. Prentice-Hall, Inc., Englewood Cliffs, NJ. 867 pp.

Millard, J. B. 1986. Seasonal distribution and uptake of gamma emitting radionuclides of the Test Reactor Area leaching ponds. Ph.D. Dissertation, Colorado State University, Ft. Collins. $191 \mathrm{pp}$.

Millard, J. B., F. W. Whicker, and O. D. Markham. 1990. Radionuclide uptake and growth of barn swallows nesting by radioactive leaching ponds. Health Physics 58:429-439.

Morris, R. C. 1994. Radioecology and ecology publications of the Idaho National Engineering Laboratory: 1974 - 1994. ESRF-003. Environmental Science and Research Foundation, Idaho Falls, ID. 35 pp.

U. S. Department of Energy. 1991. Environmental assessment of the evaporation basin, Test Reactor Area, Idaho National Engineering Laboratory. DOE/EA-0501. U.S. Department of Energy, Idaho Operations Office, Idaho Falls, ID. 21 pp. 


\title{
RADIOECOLOGY OF IODINE-129 IN THE SAGEBRUSH STEPPE ECOSYSTEM
}

\author{
Randall C. Morris ${ }^{22}$
}

\begin{abstract}
Previous investigations show that ${ }^{129} \mathrm{I}$ concentration and ${ }^{129 / 127} \mathrm{I}$ ratios were elevated in some environmental media both on and near the Idaho National Engineering and Environmental Laboratory (INEEL). The long-term trends have not been determined. This study analyzes ${ }^{129} \mathrm{I}$ concentration and ${ }^{129 / 127} \mathrm{I}$ ratios in a variety of environmental compartments. The initial objective is to determine the inventory of ${ }^{129} \mathrm{I}$ on the INEEL with the longterm objective of understanding the environmental cycling of ${ }^{129} \mathrm{I}$ and its potential impacts to humans and the environment. We are also analyzing the long-term trends in ${ }^{129} \mathrm{I}$ contamination in the environment, particularly following shutdown of the Idaho Chemical Processing Plant. Sample analyses of big game thyroids was completed and reported last year. These data are being incorporated into the current studies. Samples of sagebrush, mixed grasses and forbs, soil, and small mammals were collected from 15 locations on the INEEL and sent for analysis. Similar samples from an offsite location in a cross-wind direction from the ICPP stack were also collected and will be analyzed in early 1997.
\end{abstract}

Keywords: lodine-129 concentration, iodine-129/127 ratios, environmental cycling, environmental impacts.

\section{JUSTIFICATION}

The Idaho Chemical Processing Plant (ICPP) began processing radioactive waste in 1953. As part of plant operations, approximately $3.7 \mathrm{GBq}^{-1}\left(0.1 \mathrm{Ci} \mathrm{y}^{-1}\right)$ (U.S. Energy Research and Development Administration 1977) of ${ }^{129} \mathrm{I}$ was released to the atmosphere until October 1988, when the waste calciner was shut down for renovation. Much of this ${ }^{129} \mathrm{I}$ became incorporated into the ecosystem on and near the Idaho National Engineering and Environmental Laboratory (INEEL).

Previous studies reported above background levels of ${ }^{129} \mathrm{I}$ on and off the INEEL. These levels were found in several environmental media including vegetation (McGiff 1985), waterfowl tissues (Halford and Markham 1984), rabbit thyroids (Fraley et al. 1982) and mule deer thyroids (Markham et al. 1983). Concentrations in vegetation decreased with distance from the ICPP. However, ratios of ${ }^{129} \mathrm{I}$ to the stable nuclide of iodine, ${ }^{127} \mathrm{I}$, in mule deer harvested at Craters of the Moon National Monument and Monida Pass, on the Idaho/Montana border were 12-15 times background ratios. This may have indicated that contamination from the INEEL was carried to those locations, probably by wind. None of the past studies occurred over a long enough time period to determine long-term trends in ${ }^{129} \mathrm{I}$ contamination on and off the INEEL. In particular, current data do not allow productive estimates of long-term trends in ${ }^{129}$ I contamination after the ICPP is shut down. In 1995, we reported preliminary results from analyses of 63 mule deer and pronghorn samples for ${ }^{129} \mathrm{I}$ concentration and ${ }^{129} \mathrm{~V}^{127} \mathrm{I}$ ratio. These data, incorporated into the current study, will allow such estimates.

While ${ }^{129} \mathrm{I}$ in the environment is not expected to present a significant radiological health risk, it does present a significant public relations risk, principally because of its 16-million year half-life. In the public mind, long half-life is associated with extreme hazard. In addition, although the total dose was small, ${ }^{129} \mathrm{I}$ was responsible for $92.1 \%$, $20.5 \%$, and $59.7 \%$ of the dose to the maximally exposed individual in 1993, 1994, and 1995, respectively (Mitchell 1994, Mitchell et al. 1995, 1996). Iodine-129 is expected to become a permanent component of the environment because of its long halflife, and because some of its chemical forms readily bond to organic materials. It is expected to continuously cycle through the food chain and deliver radiation dose to 
humans and nonhuman organisms. In order to respond to public concerns and adequately assess human and ecological risks, it is important to understand the patterns and mechanisms of ${ }^{129} \mathrm{I}$ cycling in the sagebrush steppe. It is also important that we understand the long-term consequences of ${ }^{129} \mathrm{I}$ contamination for human and environmental health.

Finally, iodine is an essential element in human nutrition and scientists have invested a great deal of effort in studying its cycling in the environment (Hanson 1963, Kocher 1981). Iodine-129 serves as an analog for stable iodine and our work helps increase the understanding of that system.

For all these reasons, our overall goal is to understand ${ }^{129} \mathrm{I}$ cycling in the environment. However, it will benefit DOE to determine the extent of environmental contamination and the potential human and environmental impacts. The current project objectives reflect both the short-term goal and the longer-term goal.

\section{Objectives}

The primary goals to this study are to:

- Determine the long-term trends of ${ }^{129} \mathrm{I}$ concentration in the INEEL environment.

- Estimate the radiation dose to humans and non-human organisms from this ${ }^{129} \mathrm{I}$ contamination

In order to complete these goals, our initial objectives are to:

- Estimate the total ${ }^{129}$ I inventory on the INEEL and to partition that inventory into sagebrush, grass-forb, litter, small mammals, and four soil compartments.

- Estimate the mean residence time of ${ }^{129} \mathrm{I}$ in plant litter and soil from four depths on the INEEL.
Accomplishing these objectives will enable us to address the question of potential offsite transport of ${ }^{129} \mathrm{I}$ and the impacts thereof. In addition, the data are necessary for a comprehensive iodine cycling model for the sagebrush steppe ecosystem.

\section{PROJECT ACCOMPLISHMENTS}

In 1996, we collected samples that, when analyzed, will produce data relevant to both of the above objectives. Specifically, we:

- Identified 15 onsite and one offsite sampling locations (Fig. 26).

The 15 onsite locations were selected using a stratified random methodology for a representative sampling of the INEEL property. The offsite location was selected in native sagebrush steppe in a crosswind direction from the ICPP stack.

- Measured grass-forb, litter, and individual shrub biomass at each replicate.

At each replicate a 1- $\mathrm{m}^{2}$ plot was clipped and weighed. All litter, defined as all loose plant material laying on the ground, was also collected and weighed. An entire sagebrush plant, from within the plot if available but from nearby if not, was clipped and weighed.

- Collected three replicates each of small mammals, sagebrush, mixed grasses and forbs, litter, and four soil layers $(0-5 \mathrm{~cm}, 5$ $10 \mathrm{~cm}, 15-20 \mathrm{~cm}$, and $60-65 \mathrm{~cm})$ at each site.

After weighing, the plant material collected in the biomass measurement was sampled for iodine analysis. Soil was sampled at five locations within the plot and combined by soil depth to make each replicate sample. Small mammals were trapped for one night from an array of nine traps at each 


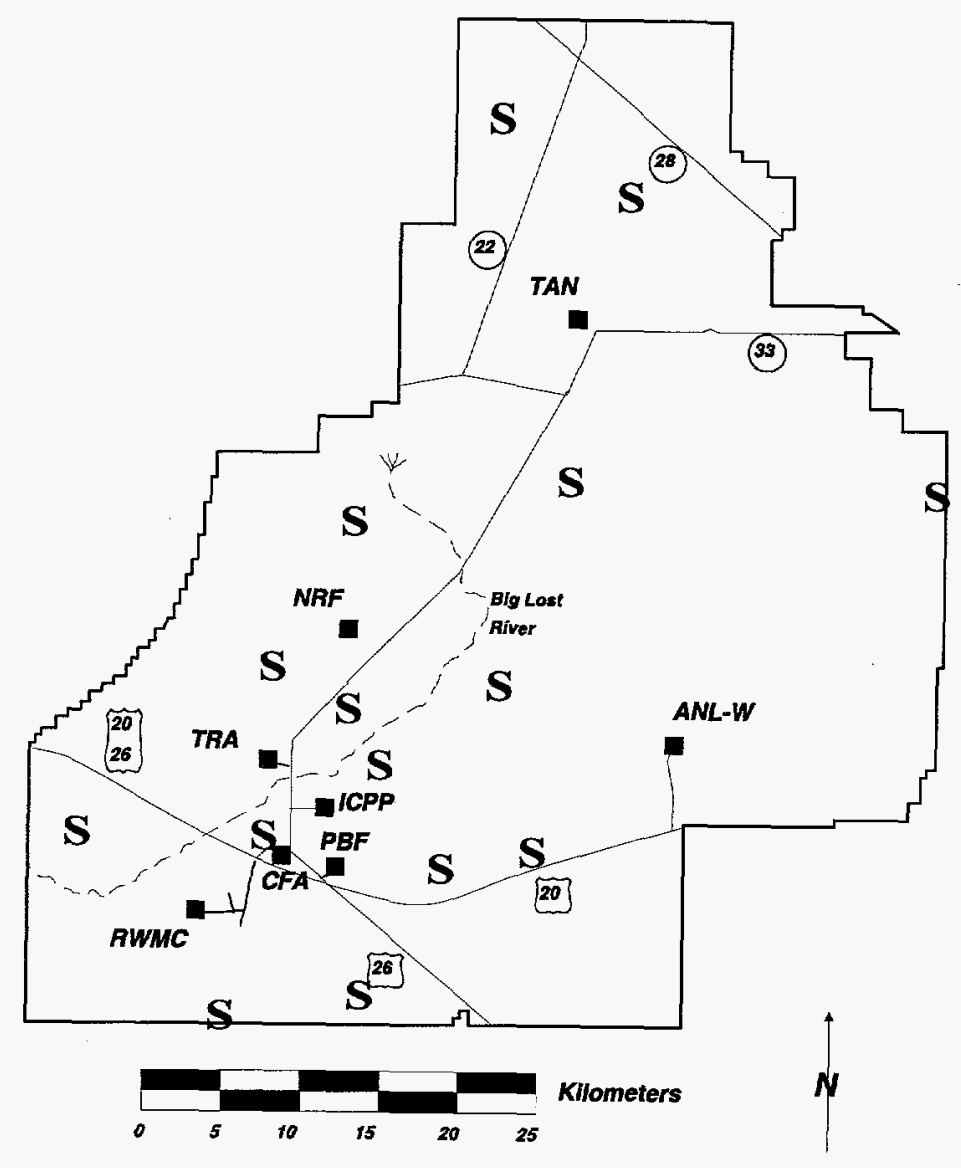

Fig. 26. Map of the Idaho National Engineering and Environmental Laboratory showing the locations of 15 sites where environmental samples were collected for ${ }^{129} \mathrm{I}$ analysis. Locations are indicted by $S$; the control location was located south of Highway 20 between Idaho Falls and the eastern boundary of the INEEL.

replicate location. All captured animals within each replicate were ground and composited.

Because some samples were not available at all sites, the total number of samples collected included 48 sagebrush, 47 mixed grasses and forbs, 48 litter, 140 soil, and 40 small mammals.

- Shipped all onsite samples to Isotrace Laboratories at the University of Toronto for analysis by Accelerator Mass Spectrometry for ${ }^{129} \mathrm{~V}^{127} \mathrm{I}$ ratio and by Neutron Activation Analysis for total iodine.

\section{IMPORTANT RESULTS}

At the 15 onsite locations, grass and forb biomass ranged from 3-143 $\mathrm{g} \mathrm{m}^{-2}$. Litter mass ranged from $4-151 \mathrm{~g} \mathrm{~m}^{-2}$. Individual sagebrush plants collected ranged from 4-115 g. Samples are currently under analysis for iodine and no results are available. 


\section{PRODUCTS}

This project is in the data collection and analysis phase. No products are completed.

\section{LITERATURE CITED}

Brauer, F. P., J. K. Soldat, H. Tenny, and R. S. Strebin, Jr. 1973. Natural iodine and iodine-129 in mammalian thyroids and environmental samples taken from locations in the United States. BNWL-SA4694, IAEA-SM-180/34. Battelle Pacific Northwest Laboratories, Richland, WA. $26 \mathrm{pp}$.

Fraley, L. F., Jr., G. C. Bowman, and O. D. Markham. 1982. Iodine-129 in rabbit thyroids near a nuclear fuel reprocessing plant in Idaho. Health Physics 43:251-258.

Halford, D. K. and O. D. Markham. 1984. Iodine-129 in waterfowl muscle from a radioactive leaching pond complex in southeastern Idaho. Health Physics 46:1259-1263.

Hanson, W. C. 1963. Iodine in the environment. Pages. 581-601 in V. Schultz and A. W. Klement, Jr., eds. Radioecology. Reinhold, New York.

Kocher, D. C. 1981. A dynamic model of the global iodine cycle for the estimation of dose to the world population from releases of iodine-129 to the environment. Environment International 5:15-31.
Markham, O. D., T. E. Hakonson, F. W. Whicker, and J. S. Morton. 1983. Iodine129 in mule deer thyroids in the Rocky Mountain West. Health Physics 45:31-37.

McGiff, T. J. 1985. Determination of I-129 and I-127 in vegetation at the Idaho National Engineering Laboratory. Unpublished thesis. Colorado State University, Fort Collins. 93 pp.

Mitchell, R. G. 1994. The Idaho National Engineering Laboratory Site Environmental Report for Calendar Year 1993. Foundation-002. Environmental Science and Research Foundation, Idaho Falls, Idaho. 132 pp.

Mitchell, R. G., D. Peterson, and D. L. Hoff. 1995. The Idaho National Engineering Laboratory Site Environmental Report for Calendar Year 1994. ESRF-009.

Environmental Science and Research Foundation, Idaho Falls, Idaho. 147 pp.

Mitchell, R. G., D. Peterson, and D. L. Hoff. 1996. The Idaho National Engineering Laboratory Site Environmental Report for Calendar Year 1995. ESRF-014. Environmental Science and Research Foundation, Idaho Falls, Idaho. $201 \mathrm{pp}$.

U. S. Energy Research and Development Administration. 1977. Final Environmental Impact Statement, Waste Management Operations, Idaho National Engineering Laboratory, Idaho. National Technical Information Service, Springfield, Virginia. 


\title{
SURFACE WATER PENETRATION AT THE SUBSURFACE DISPOSAL AREA
}

\author{
Timothy D. Reynolds ${ }^{23}$ and Teresa D. Ratzlaff ${ }^{24}$
}

\begin{abstract}
Various EPA and DOE regulations require that shallow-land burial sites for low-level radioactive wastes remain effective for at least 100 years. Primary to the success of a waste management site is the capability to keep wastes isolated from water. At the Idaho National Engineering and Environmental Laboratory, most of the annual soil moisture recharge results from precipitation that occurs during the months when plants are dormant (October March). Improvements in management practices since 1952 at the Subsurface Disposal Area (SDA) have resulted in differences in soil covers, thickness, land contours, vegetation types, and proximity of buried wastes to roads and ditches. Each of these factors influences soil moisture dynamics in the protective soil caps. Since 1988, we have measured soil moisture at $20-\mathrm{cm}$ intervals to depths of $1.6 \mathrm{~m}$ on eight study sites within the SDA. Our measurements occurred mostly during the late winter, early summer, and fall. Throughout that period, precipitation during the nongrowing season ranged from $46.6 \%$ to $135.5 \%$ of normal $(99.7 \mathrm{~mm})$. Soil moisture recharge was generally $<40-\mathrm{cm}$ deep for all areas and years except for 1989,1993, and 1995. During those years maximum infiltration was recorded at depths of $1.0,1.4$, and $1.0 \mathrm{~m}$, respectively, in some plots. Data from 1996 did not vary from the overall pattern.
\end{abstract}

Keywords: Infiltration, soil moisture recharge, Subsurface Disposal Area, volumetric soil moisture.

\section{JUSTIFICATION}

Effectively isolating hazardous wastes in shallow-land burial sites requires managing the annual influx of moisture into the soil to prevent drainage into the waste zone (Fisher 1986, Nativ 1991). This is particularly crucial for waste management sites, such as the Subsurface Disposal Area (SDA) at the Idaho National Engineering and Environmental Laboratory (INEEL), that are located above a significant aquifer. In much of the semi-arid west, including the INEEL, the highest soil water content (recharge) occurs following snow melt and spring rains (Anderson et al. 1993). Soil recharge dynamics are influenced not only by the amount and timing of precipitation, but by soil type, vegetative cover, and topographic features. For example, soils high in silt or clay have a much higher water holding capacity, and consequently lower hydraulic conductivity, than soils with a greater sand content. Soils lacking vegetation are likely over several years to accumulate more moisture that penetrates deeper than vegetated soils (Anderson 1993). In addition, a sloping soil surface directs surface water elsewhere and presumably reduces infiltration.

Contaminated wastes have been buried in trenches and pits at the Subsurface Disposal Area of the Radioactive Waste Management Complex on the INEEL since the early 1950's. Early disposal practices were naive by today's standards, and did not always adequately isolate wastes from the environment. Since then, different waste management strategies have been implemented to improve waste isolation. Perennial grasses have been planted over much of the SDA to reduce soil erosion. High clay-content soil mined from a nearby playa has been added to the original soil cover in many areas to reduce infiltration, correct for soil settling (subsidence) and provide a thicker soil barrier against burrowing animals. Drainage ditches and contoured soil covers were constructed to promote runoff from the protective caps and reduce the consequences of flooding events. The impact of these practices on soil water dynamics is not fully known.

Any waste management strategy that affects the balance between moisture input and moisture withdrawal impacts the effectiveness of the soil-plant cover system. For example, contouring the soil cover may

\footnotetext{
${ }^{23}$ Environmental Science and Research Foundation, P.O. Box 51838, Idaho Falls, ID 83405-1838

${ }^{24}$ Department of Biological Sciences, Idaho State University, Campus Box 8007, Pocatello, ID 83209
} 
reduce soil moisture recharge and subsequently decrease the vigor of the vegetation cover. Other Foundation research at the INEEL has shown that $1.6 \mathrm{~m}$ of the playa soil is sufficient to store the maximum amount of precipitation recorded on the INEEL from October through March. Our research has also shown that a vigorous stand of plants will deplete all the available soil moisture during the following growing season (Anderson et al. 1993). However, not all wastes at the SDA are under a soil mantle as thick as $1.6 \mathrm{~m}$.

Results of this long-term study will provide information on the impacts of different waste management strategies on annual and multi-annual soil water dynamics that will help determine the potential for surface water to move downward through wastes towards the aquifer. This will be useful to DOE-ID for making informed waste management decisions to meet regulatory targets.

\section{Objectives}

This study has two related long-term objectives:

- Monitor and compare the fluctuations in soil moisture content in the soil profiles of areas within the SDA likely affected by different management strategies.

The eight study plots include: two areas covered with high clay-content soil, leveled, but not contoured, and planted with crested wheatgrass, Agropyron desertorum, over waste pits 11 and 12 (Plots $11 \& 12$ for this study); an area with similar history but adjacent to a roadway where drainage ditches and road maintenance likely influence infiltration (Plot R); a level area over the former acid pit, covered with high clay- content soil and allowed to revegetate naturally until 1992, when it was planted to crested wheatgrass (Plot A); the top of a domed area between trenches 4 and 10 , contoured with lake bed high clay content soils and planted with a blend of crested wheatgrass and streambank wheatgrass, $A$. dasystachum, (Plot T); the lowest edge of the contoured area adjacent to a drainage ditch (Plot E); a level area where grasses were planted in deep native soils over trench 34 (Plot 34); and an area where grasses were planted in shallow soils (ca. $40 \mathrm{~cm}$ ) over a basalt shelf (Plot L).

- Monitor and compare the maximum depth of moisture infiltration into soils at the areas described above.

Neutron hydroprobe access tubes were installed to depths of up to $1.6 \mathrm{~m}$ in each of the study areas at the SDA. Soil moisture was calculated at $20-\mathrm{cm}$ depth increments periodically during the growing season and in the late winter. We found that soil moisture is generally static during the winter, becoming dynamic coincident with soil thawing in the spring.

Specific objectives for 1996 included:

- Taking field measurements and calculating soil moisture for each plot after snow melt and periodically during the growing season.

- Reanalyzing the complete 1988-1996 data set.

\section{PROJECT ACCOMPLISHMENTS}

- We took field measurements and calculated estimates of soil moisture seven times from February through October. 
Table 15. Annual percentage of average precipitation ( $99.7 \mathrm{~mm}$ water equivalent) falling during the non-growing season (October through March) at the INEEL, maximum depth of recorded infiltration (recharge), and average spring maximum and fall minimum volumetric soil water content on all study plots at the Subsurface Disposal Area.

\begin{tabular}{lcccc} 
& & & & \multicolumn{2}{c}{$\begin{array}{c}\text { Average volumetric soil water } \\
\text { content } \\
(\%)\end{array}$} \\
Year & $\begin{array}{c}\text { Precipitation } \\
(\% \text { of normal })\end{array}$ & $\begin{array}{c}\text { Maximum infiltration } \\
\text { depth } \\
(\mathrm{cm})\end{array}$ & Spring & Fall \\
\hline 1988 & 46.6 & 40 & 18.3 & 17.0 \\
1989 & 98.3 & $100^{1}$ & 20.7 & 17.0 \\
1990 & 54.2 & 40 & 18.1 & 16.7 \\
1991 & 48.1 & 40 & 17.6 & 17.1 \\
1992 & 50.4 & 40 & 20.4 & 17.1 \\
1993 & 130.4 & $140^{1}$ & 23.9 & 19.4 \\
1994 & 63.7 & 40 & 19.4 & 16.7 \\
1995 & 135.5 & $120^{2}$ & 20.2 & 17.1 \\
1996 & 93.6 & $120^{2}$ & 19.9 & 16.4 \\
\hline
\end{tabular}

${ }^{1}$ Infiltration reached this depth on two plots.

${ }^{2}$ Infiltration reached this depth on one plot.

We recorded nearly average precipitation during the non-growing season (October through May; Table 15). For most plots, infiltration was $\leq 60 \mathrm{~cm}$ (Fig. 27). Soil moisture increased at the $80-\mathrm{cm}$ depth in plot A (former acid pit; Fig. 27d) and possibly to $100 \mathrm{~cm}$ in Plot E (Fig. 27f).

- We analyzed and compared soil moisture data from 1988-1996.

Maximum recharge depths were examined by graphing volumetric water content at 20-cm depth increments for each sampling date. Soil moisture recharge was $\leq 40 \mathrm{~cm}$ deep for all plots in 1988, 1990, 1991, 1992, and 1994. In 1989, 1993, 1995 and 1996, some study plots were wetted to $1.0,1.4,1.2$ $\mathrm{m}$, and $1.2 \mathrm{~m}$ respectively. Some infiltration to or below $100 \mathrm{~cm}$ occurred following every winter (October through March) with nearly average or greater precipitation (Table 15).

- We calculated spring (maximum) and fall (minimum) volumetric soil moisture for all plots and added these to the long-term display for each plot (Fig. 28).

Consistent with previous years, spring volumetric soil moisture contents for all plots were generally lower than those found in other Foundation studies (Anderson et al. 1993, Anderson and Ratzlaff this volume). This was a likely consequence of mowing the standing vegetation on the SDA in the fall, which limits the amount of snow 

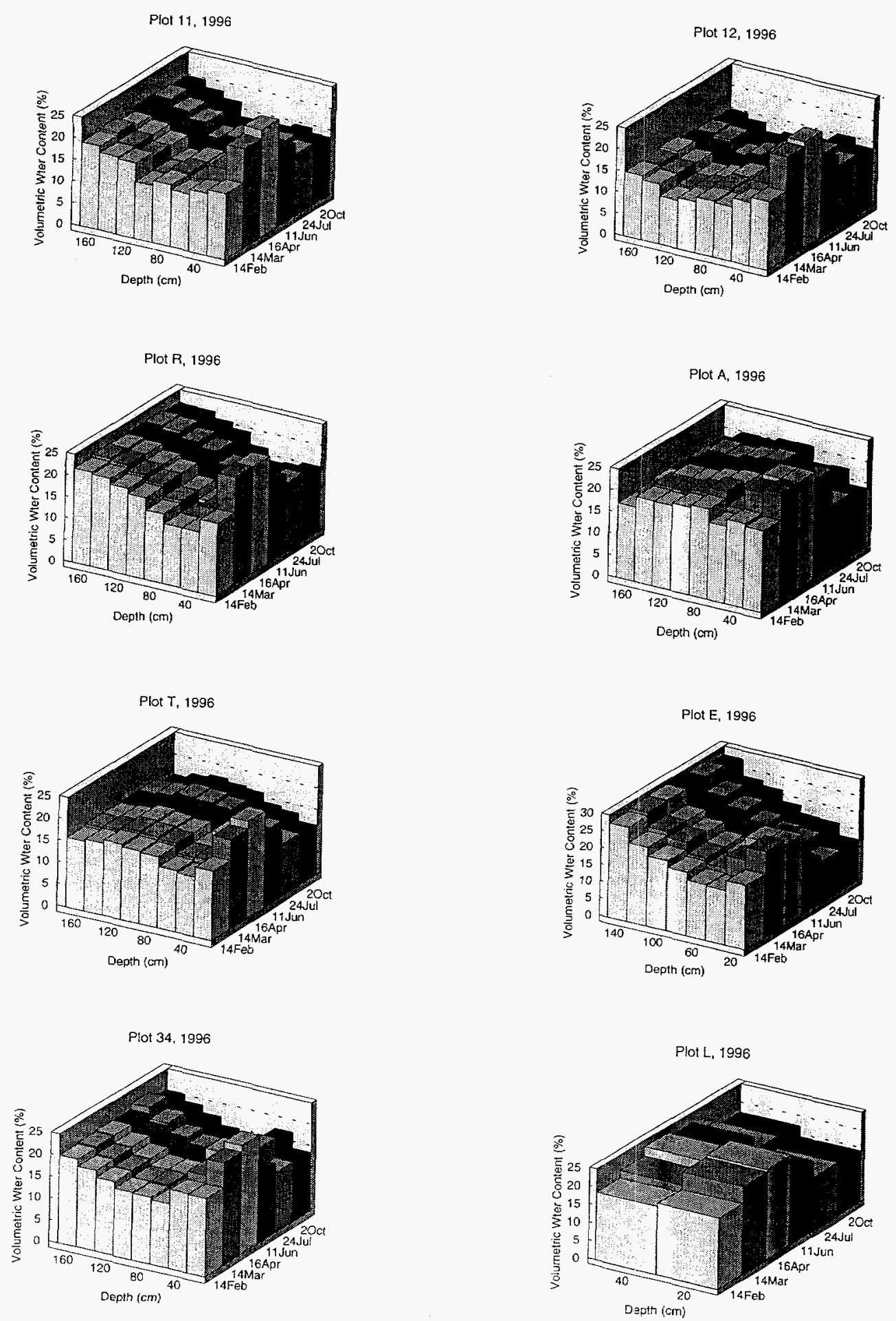

Fig. 27. Volumetric water content (\%) at 20-cm depth increments on specific dates in 1996 in eight areas of different waste cover treatments in the Radioactive Waste Management Complex at the Idaho National Engineering and Environmental Laboratory. Plot codes are defined in the text. 
Spring (max) and \& Fall (min) $\mathrm{H} 2 \mathrm{O}$
Plot 11

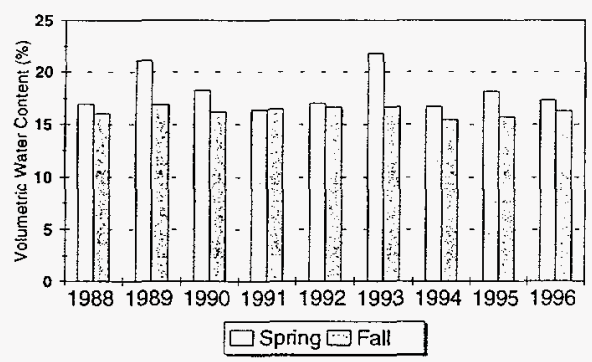

Spring (max) and \& Fall (min) H2O
Plot A

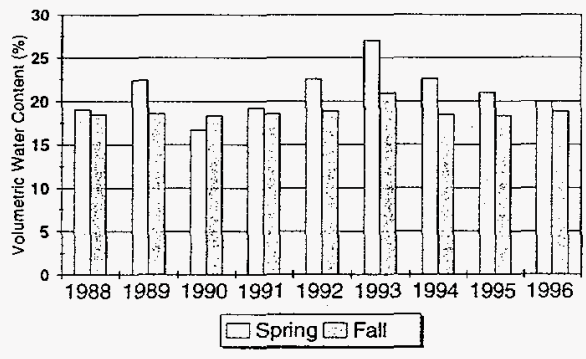

Spring (max) and \& Fall (min) $\mathrm{H} 2 \mathrm{O}$
Plot T

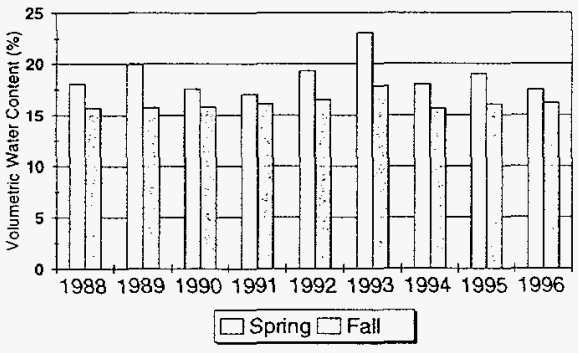

Spring (max) and \& Fall (min) $\mathrm{H} 2 \mathrm{O}$

Plot 34

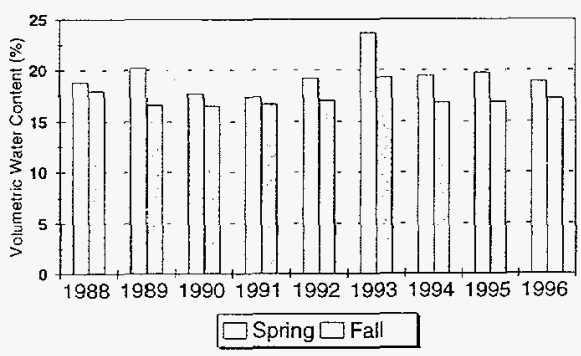

Spring (max) and \& Fall (min) H2O

Plo: 12

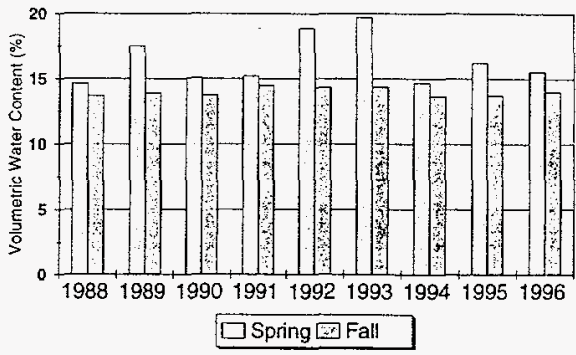

Spring (max) and \& Fall (min) $\mathrm{H} 2 \mathrm{O}$
Plot A

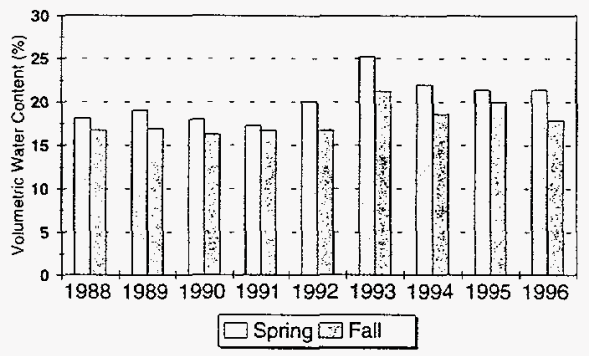

Spring (max) and \& Fall (min) H2O
Plot E

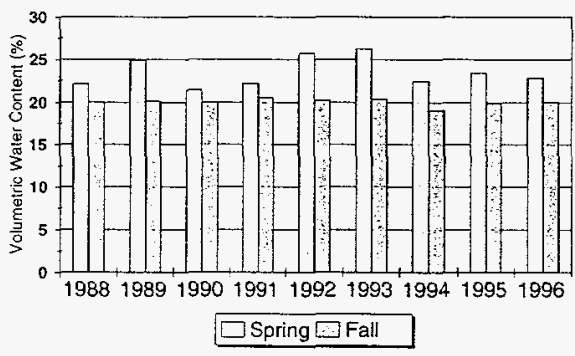

Spring (max) and 8 Fal (min) H2O

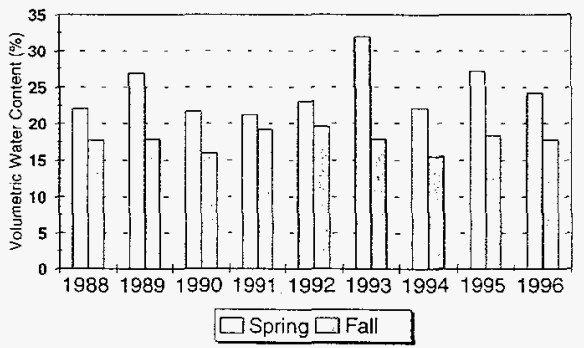

Fig. 28. Total volumetric water content $(\%)$ in areas of different waste cover treatments in the Radioactive Waste Management Complex at the Idaho National Engineering and Environmental Laboratory. Water contents are given at peak recharge (spring) and maximum depletion (fall) from 1988 - 1996. Plot codes are defined in the text. 
accumulation on the plots. Fall volumetric soil moisture generally exceeded that in other studies, suggesting either differences in the lower limits of extraction by plants (perhaps influenced by mowing), or soil differences in water holding capacity. Plot $\mathrm{E}$ continues to hold more total moisture (Fig. 28f) and more moisture at depth (Fig. 27f) than other plots. We suspect a capillary break, possibly an old road, exists just below $140 \mathrm{~cm}$. Early photos of the SDA bear this out. Like many of the plots in Fig. 27, moisture at depth in Plot $\mathrm{E}$ is greater than at intermediate depths, but remains static throughout the year. This likely represents water captured during cap construction. In addition, Plot $E$ was the only plot in which water reached $120 \mathrm{~cm}$ in 1995 and 1996. Infiltration in other plots was consistently $40-60 \mathrm{~cm}$ less in 1995 and $80 \mathrm{~cm}$ less in 1996. We believe water content in plot $E$ is influenced by a drainage channel excavated near the plot during the second year of the study.

\section{IMPORTANT RESULTS}

The precipitation received during the nongrowing season (October 1994 through March 1995) was $93.6 \%$ of the 45 -year average. Soil moisture content reached the annual maximum ( $19.9 \%$ by volume) in April. Recharge for most plots was $\leq 60 \mathrm{~cm}$. There are several patterns revealed in the data. Plots $11 \& 12$ (planted with crested wheatgrass, no contouring, and imported soils) generally had the lowest spring and fall volumetric soil water content. Plot $\mathrm{L}$ usually had the highest spring volumetric soil moisture content. Because this was a shallow plot $(40-\mathrm{cm}$ depth) over basalt, the high volumetric water content was expected. Plots $\mathrm{E}$ and $\mathrm{R}$ (near a road and a drainage ditch at the edge of a contoured area) consistently had the highest fall volumetric soil water content. The depth of spring soil moisture recharge was usually less for the study areas near roads or drainage ditches than for other study sites, until 1995.
In 1995 and 1996, spring increases in soil moisture were $120 \mathrm{~cm}$ for plot E, likely as a results of ponding in the drainage ditch next to the plot. Since the study began, average or greater precipitation during the nongrowing season from October through March usually wetted some spring soils to depths of $\geq 80$ $\mathrm{cm}$. This is deeper than the $0.5-\mathrm{m}$ (1.5-feet) soil cover originally placed over much of the SDA. Soil moisture rarely changed at depths $\geq 120 \mathrm{~cm}$. The additional $0.6-1.2 \mathrm{~m}(2-4$ feet) of soil placed over most of the SDA in 1979 (Truitt 1984, J. Bishoff, personal communication) produced a total soil thickness that appears adequate to preclude moisture drainage into the waste zone for the precipitation conditions experienced during most years of this study.

\section{PRODUCTS}

A technical manuscript from this research is being prepared. An article summarizing this project is being redrafted for distribution in the Foundation Focus. The study was described during several presentations summarizing waste management research on the INEEL.

\section{LITERATURE CITED}

Anderson, J. E., R. S. Nowak, T. D. Ratzlaff, and O. D. Markham. 1993. Managing soil moisture on waste burial sites in arid regions. Journal of Environmental Quality 22:62-69.

Fisher, J. N. 1986. Hydrogeologic factors in the selection of shallow land burial for the disposal of low-level radioactive waste. Geological Survey Circular (U.S.) 973.

Nativ, R. 1991. Radioactive waste isolation in arid zones. Journal of Arid Environments 20:129-140.

Truitt, D. J. 1984. SDA Maintenance Plan Contour design and work schedule. Engineering Design File Number 187. EG\&G Idaho, Inc., Idaho Falls, Idaho. 


\title{
OCCURRENCE OF SMALL OWL SPECIES ON THE IDAHO NATIONAL ENGINEERING AND ENVIRONMENTAL LABORATORY
}

\author{
Natalie A. Fahler ${ }^{25}$
}

\begin{abstract}
During 1996, burrowing owl surveys revealed 11 successful nesting pairs of 17 attempts. Data on productivity, burrow and vegetation measurements, and prey composition in pellets of burrowing owls was also obtained. In addition, five long-eared owl nests were discovered on the site, and incidental sightings of short-eared owls were recorded. Data were collected on responses of arboreal owl species to tape-recorded calls broadcast throughout the night in juniper woodlands on the Idaho National Engineering and Environmental Laboratory (INEEL) from March through May. The only small owl detected was a boreal owl heard on one occasion. The bird did not vocalize again to allow tape-recording for verification. Long-eared and great horned owls were commonly detected during these surveys.
\end{abstract}

Keywords: Burrowing owls, long-eared owls, sensitive species, small owl species.

\section{JUSTIFICATION}

The Idaho National Engineering and Environmental Laboratory (INEEL) was designated as a National Environmental Research Park in 1975. Access onto the site is limited to authorized personnel. The large size and isolation of the INEEL provides an excellent field laboratory for study of biota typical of the cold desert habitat of the upper Snake River Plain (Harniss and West 1973).

Since the passage of the Endangered Species Act in 1973, considerable national effort by government agencies has been directed toward the conservation and recovery of plants and animals that meet criteria for rare, threatened or endangered status. Species of special concern and sensitive species are additional classifications, as defined in the Idaho Conservation Data Center, for those species experiencing low or significantly declining populations, small and/or sparsely dispersed populations, or significant habitat losses and limitations.

The western burrowing owl (Speotyto cunicularia), listed by the Bureau of Land Management as a sensitive species, visits the INEEL each spring to nest and raise young. Due to their sensitive status, information on burrowing owl densities, distribution, and habitat requirements on the INEEL is necessary to help INEEL personnel expedite NEPA field evaluations and avoid costly mitigation. With sound and current information on INEEL burrowing owls, the DOE and other INEEL employees can make wise land use decisions and have access to defensible information in case of litigation.

Several other small owls species that have been recorded, but not confirmed, on or near the INEEL are included in the Idaho Conservation Data Center's listing of Rare, Threatened and Endangered Plants and Animals of Idaho (Mosely and Groves 1994). The Idaho Department of Fish and Game lists the boreal owl (Aegolius funereus), flammulated owl (Otus flammeolus), and northern pygmy owl (Glaucidium gnoma) as species of special concern. The U.S. Forest Service and the Bureau of Land Management classifies the boreal owl and flammulated owl as sensitive species. The western screech owl (Otus kennicottii) and the northern saw-whet owl (Aegolius acadicus) are also suspected to occur on the INEEL.

Owls and other raptors are considered indicator species; they exist at high trophic levels and subsequently are sensitive to environmental toxins. Contaminants obtained through their prey can accumulate in the birds, often resulting in deaths of individuals or reproductive abnormalities in a species.

\footnotetext{
${ }^{25}$ Department of Wildlife and Fisheries Sciences, South Dakota State University, Brookings, SD 57007-1696
} 
Knowledge of seasonal occurrence and habitat use by small owl species on the INEEL will expand the database for these elusive birds and help assure sound management in the future to allow continued survival of healthy owl populations. In addition, baseline data on owls of the INEEL will aid future research on the long-term effects of energy development activities on seasonal and resident wildlife populations of the INEEL, and may provide an early warning system of environmental hazards.

\section{Objectives}

The goal of this study was to document the occurrence of small owl species on the INEEL with emphasis on a) determining the density, productivity, and habitat use of nesting burrowing owls on the INEEL, and $b$ ) determining seasonal use of juniper woodland by arboreal owl species. Specific objectives were to:

- Estimate burrowing owl population size on the INEEL and compare current numbers and productivity with prior research.

- Evaluate burrowing owl occurrence and nest sites in relation to vegetation, burrow and soil characteristics on the INEEL.

- Determine the status of small owl species on the INEEL listed as sensitive or species of special concern by Idaho federal and state agencies.

- Determine small owl species occurrence on the INEEL during late winter and spring and obtain baseline data for use in long-term population analysis.

- Attempt to confirm the presence of small owls suspected or reported, but never officially verified on the INEEL.
- Evaluate the differences in owl responsiveness to broadcasts of calls over the course of the night.

\section{PROJECT ACCOMPLISHMENTS}

- Night-long surveys were completed from March through May 1996 for arboreal owl species.

- We surveyed the INEEL for burrowing owls.

- Productivity data were gathered for nesting burrowing owls.

- Burrowing owl pellets were collected from burrow mounds and surrounding perches from May through August, and will be analyzed for diet composition.

- Burrow and surrounding vegetation measurements were recorded for each nesting burrow.

- We surveyed $25 \mathrm{~km}$ of the Big Lost River for long-eared owl nests.

\section{IMPORTANT RESULTS}

Surveys for burrowing owls revealed 11 successful nesting pairs of 17 known nesting attempts on the INEEL. These numbers represent a notable increase over the six nests detected during a study of burrowing owls on the INEEL during the late 1970s (Gleason 1978). Of the six unsuccessful nesting attempts, two nests were depredated, two nest burrows were abandoned for unknown reasons, and two burrows that obviously had been occupied by burrowing owls during mid-summer were abandoned prior to discovery.

On two occasions burrowing owls were sighted in burned areas. A single bird was sighted in a 1995 burn on one occasion late in the breeding season, but was not observed in 
the area again. A family was discovered in a 1996 burned area in late summer. All chicks were able to fly and there was no evidence that either of the two occupied burrows had served as nest burrows. The location of the original nest site is not known.

Long-eared owls and great horned owls were commonly detected in the night-long surveys for arboreal owls. Hanson (1994) reported flammulated, northern saw-whet, western screech, and boreal owls during surveys conducted on the INEEL in 1992 and 1993. None of these were confirmed on the INEEL in 1996. A probable boreal owl call was heard, but was not verified by tape-recording or photograph. Hanson reported flammulated owls as the second most commonly heard arboreal species during his surveys, surpassed only by great horned owls. Numerous vocalizations were reported as early as February although flammulated owls are not known to reach breeding territories in Idaho before April (Phillips 1942, Johnson 1963). Similarity between the primary calls of flammulated and long-eared owls may explain this unusual report of flammulated owls as well as the relatively low number of long-eared owls reported by Hanson (1994).

A survey of $25 \mathrm{~km}$ of the Big Lost River revealed three long-eared owl nests, consistent with data collected in 1975 as part of an INEEL raptor project (Craig 1977), and two other long-eared nests were discovered in junipers located in isolated areas of the site. Incidental sightings of short-eared owls (Asio flammeus) were recorded, though formal surveys specifically for this species were not performed.

\section{PRODUCTS}

This was the first field season for this study. It is likely that with the additional data collected during CY-97, several manuscripts will be supported.

\section{LITERATURE CITED}

Craig, T. H. 1977. Raptors of the Idaho National Engineering Laboratory Site. Unpublished MS thesis. Idaho State University, Pocatello, Idaho. $102 \mathrm{pp}$.

Gleason, R. S. 1978. Aspects of the breeding biology of Burrowing Owls in southeastern Idaho. Unpublished MS thesis. University of Idaho, Moscow, Idaho. 46 pp.

Hanson, R. W. 1994. Raptor use of the Idaho National Engineering Laboratory. Unpublished MS thesis. South Dakota State University, Brookings, South Dakota. $141 \mathrm{pp}$.

Harniss, R. O. and N. E. West. 1973. Vegetation patterns of the National Reactor Testing Station, Southeastern Idaho. Northwest Science 47:30-43.

Johnson, N. K. 1963. The supposed migratory status of the flammulated owl. Wilson Bulletin 75:174-178.

Mosely, R. and C. Groves. 1994. Rare, threatened, and endangered plants and animals of Idaho. Third edition. Conservation Data Center, Idaho Department of Fish and Game, Boise, Idaho. $39 \mathrm{pp}$.

Phillips, A. R. 1942. Notes of the migrations of the elf and flammulated screech owls. Wilson Bulletin 54:132-137. 


\title{
FACTORS THAT AFFECT THE DISTRIBUTION OF SOIL LICHENS AT THE IDAHO NATIONAL ENGINEERING AND ENVIRONMENTAL LABORATORY
}

\author{
Douglas Evans ${ }^{26}$
}

\begin{abstract}
Microbiotic crusts, consisting of mosses, lichens, algae, and bacteria, are important components of cold-desert ecosystems. They stabilize soil surfaces and reduce erosion, influence seedling establishment, and contribute to soil fertility. However, crust organisms are susceptible to disturbances such as livestock grazing and fire. Because the Idaho National Engineering and Environmental Laboratory (INEEL) includes large areas that have been free from such disturbances, it provides a unique opportunity to study factors that affect the distributions of crust organisms. Data on lichens and mosses and associated soil surface characteristics were collected in conjunction with collection of vascular plant data on 92 permanent vegetation plots at the INEEL. The cold-desert communities at the INEEL have about 20 species of soil lichens, 18 of which were recorded on the permanent plots. Collema tenax, the only lichen identified at the INEEL capable of nitrogen fixation, was among the rnost abundant. Lichen cover and species richness were positively correlated with stability of the soil surface. Within plots, microtopography significantly influenced lichen abundance. No lichens were observed on plots that had burned in a wildfire one year earlier.
\end{abstract}

Keywords: Lichens, microbiotic crusts, microtopography, soil stability.

\section{JUSTIFICATION}

In most arid and semi-arid regions, a crust consisting of lichens, mosses, algae, and bacteria forms on the surface of undisturbed soils (West 1990, St. Clair and Johansen 1993). Such "microbiotic crusts" stabilize soil surfaces and reduce erosion (Booth 1941, Fletcher and Martin 1948, Loope and Gifford 1972). Recent evidence indicates that these crusts may also significantly improve soil fertility (e.g., West and Skujins 1977, Klubek and Skujins 1980, Jeffries et al. 1992). Microbiotic crusts may be the most important source of fixed nitrogen in some cold-desert communities (Evans and Ehleringer 1993).

In areas not grazed by domestic livestock in the cold deserts of the Intermountain West, lichens provide a significant portion of the ground cover in sparsely vegetated communities. These communities evolved in the relative absence of large, hooved mammals (Mack and Thompson 1982). Bison, elk, pronghorn and deer that were present either occurred in small herds or in such low numbers that their periodic trampling could be tolerated by microbiotic communities. Native herbivores likely inhabited lower elevation sites in the winter and early spring when soil crusts were wet from seasonal precipitation and returned to the surrounding mountains as the dry summer approached (St. Clair et al. 1993). The introduction of large herds of livestock increased the frequency and intensity of disturbance, heavily damaging microbiotic crust communities throughout the region. Microbiotic crusts are especially vulnerable to grazing disturbances during the dry summer months.

Cover of both vascular-plant and nonvascular/microbiotic communities may decrease in response to grazing, but the microbiotic community typically is more susceptible, experiencing greater losses in cover (Brotherson et al. 1983). Within the microbiotic community, lichens and mosses are more easily damaged by grazing than are soil algae (Brotherson et al. 1983). Lichens are particularly vulnerable because they grow slowly and depend on a stable substrate for anchorage. Studies of rates of recovery of microbiotic crusts following termination of grazing by domestic stock have shown that lichens can reestablish pre-grazing cover after 15-20 years. Recovery of lichen species

\footnotetext{
${ }^{26}$ Department of Biological Sciences, Idaho State University, Pocatello, Idaho 83209-8007
} 
richness may require in more than 40 years (Anderson et al. 1982).

Crusts are also seriously damaged by wildfire and by motorized off-road vehicle traffic (Johansen et al. 1982). Increased frequency of wildfire in the Intermountain West, resulting from the introduction of alien annual plants such as cheatgrass (Bromus tectorum)(Klemmedson and Smith 1964, Whisenant 1990), may devastate crust communities because lichen populations may be unable to recover between recurring fires. No study has addressed this possibility.

Large portions of the INEEL have been free from the impacts of livestock grazing or wildfire since 1950 , providing a natural laboratory for studies of the structure and function of microbiotic crusts communities. Recent wildfires at the INEEL provide an opportunity to assess the impacts of fire on crust organisms. No study of microbiotic crusts per se has been conducted at the INEEL. INEEL lichens were inventoried by Pearson and Rope (1987), and Rope and Pearson (1990) investigated the use of lichens as air quality indicators. Understanding the mechanisms that limit the distribution of soil lichens as part of the microbiotic community will allow us to develop management strategies designed to preserve healthy, diverse sagebrush steppe communities. Monitoring these organisms simplifies and expedites NEPA field evaluations for activities at the INEEL.

\section{Objectives}

The goal of this study is to identify and understand the biotic and abiotic factors that limit the distribution of soil lichens in different habitats at the INEEL. Specific objectives are to:

- Determine whether the distributions of species of soil lichens are related to microtopographic features of the soil surface including: the zone of litter accumulation and soil deposition beneath shrubs, the bare interspace between shrubs, and the transitional zone between the two.

- Determine whether there are associations (positive or negative) between the presence of vascular plants and various species of lichens.

- Determine whether cover of soil lichens is related to soil surface cohesiveness.

- Determine whether cover of soil lichens is related to soil texture (we predict that lichen cover will be higher on soils having higher clay content).

- Assess the impacts of the 1994 Butte City fire on lichen abundance and richness.

- Compare lichen cover and species richness between grazed and not grazed areas at the INEEL.

\section{PROJECT ACCOMPLISHMENTS}

- Measured cover of visible microbiotic crusts (mosses and lichens) and sampled associated soil surface characteristics in conjunction with collecting vegetation data at all of the permanent vegetation plots in 1995.

- Data on lichen abundances and soil surface characteristics were entered into computer files and numerous analyses (see below) were completed.

- Analyses of soil textures were completed for samples from the permanent plots.

\section{IMPORTANT RESULTS}

- Lichen cover and species richness were positively correlated with cohesiveness of the soil surface. 
- Lichen cover and species richness were affected by within-plot microtopography; lichen cover was significantly higher on the transitional zones next to shrubs or perennial grasses than on the accumulation and deposition zone beneath shrubs or on the interspaces.

- Lichen cover and species richness were low on plots having sandy soils.

- Visible lichens were absent in 1995 from experimental plots that burned in 1994.

- Collema tenax, the only lichen identified at the INEEL capable of nitrogen fixation, was among the most abundant.

\section{PRODUCTS}

A Master's thesis and peer reviewed publication based on this project are in preparation.

\section{LITERATURE CITED}

Anderson, D. C., K. T. Harper, and R. C. Holmgren. 1982. Factors influencing development of cryptogamic soil crusts in Utah deserts. Journal of Range Management 35:180-185.

Booth, W. E. 1941. Algae as pioneers in plant succession and their importance in erosion control. Ecology 22:38-46.

Brotherson, J. D., S. R. Rushford, and J. R. Johansen. 1983. Effects of long-term grazing on cryptogam crust cover in Navajo National Monument, Arizona. Journal of Range Management 36:579-581.

Evans, R. D., and J. R. Ehleringer. 1993. A break in the nitrogen cycle in aridlands? Evidence from "delta" $15 \mathrm{~N}$ of soils. Oecologia 94:314-317.

Fletcher, J. E., and W. P. Martin. 1948. Some effects of algae and moulds in the rain crust of desert soils. Ecology 29:95-100.
Jeffries, D. L., J. M. Klopatek, S. O. Link, and H. Bolton. 1992. Acetylene reduction of cryptogamic crusts from a blackbrush community as related to resaturation/ dehydration. Soil Biology and Biochemistry 24:1101-1105.

Johansen, J. R., A. Javakul, and S. R. Rushforth. 1982. Effects of burning on the algal communities of a high desert soil near Wallsburg, Utah. Journal of Range Management 35:598-600.

Klemmedson, J. O., and J. G. Smith. 1964. Cheatgrass (Bromus tectorum L.). Botanical Review 30:226-262.

Klubek, B., and J. Skujins. 1980. Heterotrophic nitrogen fixation in arid soil crusts. Soil Biology and Biochemistry 12:229-236.

Loope, W. L., and G. F. Gifford. 1972. Influence of a soil microfloral crust on select properties of soils under pinyon-juniper in southeastern Utah. Journal of Soil and Water Conservation 27:164-167.

Mack, R. N., and J. N. Thompson. 1982. Evolution in steppe with large, hooved mammals. American Naturalist 119:757-773.

Pearson, L. C., and S. K. Rope. 1987. Lichens of the Idaho National Engineering Laboratory. U.S. Department of Energy, Idaho Operations Office, Idaho Falls.

Rope, S. K. and L. C. Pearson. 1990. Lichens as air pollution biomonitors in a semiarid environment in Idaho. The Bryologist 93:50-61.

St. Clair, L. L., and J. R. Johansen. 1993. Introduction to the symposium on soil crust communities. Great Basin Naturalist $53: 1-4$.

St. Clair, L. L, J. R. Johansen, and S. R. Rushforth. 1993. Lichens of soil crust communities in the Intermountain Area of the western United States. Great Basin Naturalist 53:5-12. 
West, N. E., and J. Skujins. 1977. The nitrogen cycle in North American cold-winter semidesert ecosystems. Oecologia Plantarum 12:45-53.

West, N. E. 1990. Structure and function of microphytic soil crusts in wild ecosystems of arid to semi-arid regions. Advances in Ecological Research 20:179-223.
Whisenant, S. G. 1990. Changing fire frequencies on Idaho's Snake River Plains: Ecological and management implications. Pages 4-10 in Proceedings - symposium on cheatgrass invasion, shrub die-off, and other aspects of shrub biology and management. E. D. McArthur, E. M. Romney, S. D. Smith, and P. T. Tueller, compilers, Intermountain Research Station, Ogden, Utah. 


\title{
FIRE ECOLOGY OF THE IDAHO NATIONAL ENGINEERING AND ENVIRONMENTAL LABORATORY
}

\author{
Seanne Patrick and Jay E. Anderson ${ }^{27}$
}

\begin{abstract}
Fire played an important role in the vegetation history of the Idaho National Engineering and Environmental Laboratory (INEEL). However, current knowledge of postfire vegetation response is insufficient to guide management of the area. Large fires at the INEEL in 1994, 1995, and 1996 underscore the need for a fire management plan and provide unique opportunities for research. To document postfire vegetation development, we measured plant cover and seedling densities in 1995 and 1996 at two sites burned in 1994. Native species that survived the fire and re-sprouted dominated the cover at both sites. Total plant cover in 1996 on plots burned in 1994 was $23 \%$ compared with $28 \%$ on adjacent unburned plots, indicating that vegetation can recover quickly on areas having healthy populations of native species. To compare the potential of native perennials vs. exotic annuals for filling gaps in vegetal cover of burned areas, we established plots in an area burned in 1995 where over half of the seedlings were exotic annuals. We also investigated the origin of a prominent landscape feature at the INEEL, the principal lineament, which we postulate to have resulted from a large wildfire. Charcoal in soil samples excavated from the principal lineament provide additional evidence in support of that hypothesis.
\end{abstract}

Keywords: exotic plants, plant cover, principal lineament, vegetation recovery.

\section{JUSTIFICATION}

The climate of the cold deserts of western North America predisposes many plant communities of the region to recurring wildfire. Thus, fire played an important evolutionary role in determining the structure and dynamics of sagebrush (Artemisia) steppe. Although big sagebrush (Artemisia tridentata), the dominant shrub of the region, is killed by wildfire, other species survive and respond vigorously to postfire conditions (Young \& Evans 1978, Wright et al. 1979, Cole 1987, Ratzlaff and Anderson 1995).

Estimates of return intervals for fires in sagebrush steppe prior to European settlement range from ca. 20 to 100 years (Houston 1973, Wright et al. 1979, Wright and Bailey 1982). Whisenant (1989) suggested that such fires were relatively small and patchy and resulted in a landscape mosaic of patches differing in size and age. The introduction of cheatgrass (Bromus tectorum) and other exotic annuals dramatically changed the effects of fire, resulting in the conversion of native sagebrush steppe to annual grasslands (Hosten \& West 1994, Whisenant 1989). Cured cheatgrass plants are extremely flammable, and dense stands of this and other exotic annuals have decreased fire return intervals to five years or less in some sagebrush steppe areas (Klemmedson and Smith 1964, Young and Evans 1978, Wright \& Bailey 1982, West and Hassan 1985, Brown and Minnich 1986). Knapp (1996) estimated that areas dominated by cheatgrass are 10-500 times more likely to burn than areas dominated by native bunchgrasses. Not only have fires become more frequent, they also have become larger and more uniform, resulting in fewer patches of unburned vegetation within burned areas (Whisenant 1990). This limits the potential for native plant populations to recover because the exchange of propagules between patches of different ages is reduced.

Composition of the prefire plant community largely dictates postfire vegetation development because of the presence or absence of species with particular traits (Noble and Slatyer 1980, Humphrey 1984). The initial postfire community will consist of vegetative survivors and individuals recruited from on-site seed reserves. Although the bulk of cheatgrass seed may be consumed by wildfire (Young et al. 1976, Young and Evans

\footnotetext{
${ }^{27}$ Department of Biological Sciences, Idaho State University, Pocatello 83209-8007
} 
1978), sufficient seeds typically survive to establish a vigorous postfire stand. West and Hassan (1985) studied postfire recovery in a sagebrush steppe in Utah where a high density of native perennial bunchgrasses existed before the fire. They documented a five-fold increase in cheatgrass cover and a 55-fold increase in its standing crop in the first postfire season compared with the prefire levels. Cover and standing crop of the perennial bunchgrasses reached preburn levels by the second postfire year, and the relative contribution of cheatgrass to total production had declined. West and Hassan's study shows that cheatgrass can quickly assume dominance after wildfire, even in communities where it was a minor component and perennial grasses were abundant prior to the fire. However, whether the perennials will eventually regain dominance on such sites is unclear. If healthy stands of native grasses are present before the fire and survival is high, which is often the case, the established perennials may compete effectively and quickly assume dominance (Ratzlaff and Anderson 1995).

The fire history of the Idaho National Engineering and Environmental Laboratory (INEEL) prior to 1950 is not well documented, but fire scars apparent in satellite images or aerial photographs document that fire played an important role in the vegetation history of the area (Anderson et al. 1996). However, knowledge of the fire ecology of the INEEL is insufficient to guide management of the area so that damage to facilities from catastrophic fires can be avoided and the long-term integrity of its rich ecological resources can be insured. The need for better understanding of postfire vegetation response has become more critical because of the increased distribution and abundance of exotic annuals and because we have witnessed large fires in each of the past three summers at the INEEL.

The scars of nine fires that burned during this century prior to 1994 have been mapped from satellite imagery. Most were small, ranging in size from a few to a few hundred hectares. The two largest burned some 1,400 ha in about 1910 and 1,200 ha in 1949. Wildfires during the past three years have been much larger. The summer of 1996 produced six fires that consumed 14,750 ha (36,450 acres); the largest burned 10,680 ha (26,400 acres). In 1995,2750 ha $(6,800$ acres) at the Argonne West facility were burned, while in 1994 the Butte City Fire burned 6920 ha (17,100 acres). These fires burned virtually all of the aboveground biomass, and severe wind erosion followed. Dust plumes from the 1995 and 1996 fires created problems at Argonne National Laboratory-West (ANL-W) and created hazardous driving conditions that forced closure of Highway 20 on several occasions.

These recent fires were all human caused, but it is clear that they would have burned equally large areas regardless of the source of ignition because conditions were ripe to support large fires. A fire ignited by lightning in early August of 1996 burned 89,000 ha (220,000 acres) south of Big Southern Butte. This spate of large fires raises several important questions: To what extent were the fires a consequence of the presence of exotic species? Will these large fires result in conversion of native shrub-steppe to communities dominated by annuals, or will healthy populations of native species regain dominance? Is the size of these fires unprecedented?

The 1994 Butte City fire provided a unique opportunity to address such questions because prefire vegetation data for the area exist. In 1980, we established 34 permanent sample plots on the western edge of the INEEL to study the response of vegetation to a prescribed burn. Baseline cover data for all vascular plants were collected at all of the plots. The prescribed burn produced an incomplete burn, so no follow-up studies were conducted. However, the plots are intact and half of them were completely burned in the 
1994 fire. The unburned plots serve as a control, documenting changes that have taken place since 1980 and providing estimates of the prefire species composition.

One factor that undoubtedly affected the size and severity of the recent fires was the build up of fuels resulting from exceptionally wet growing seasons in 1993 and 1995. Casual observation indicates that exotic species, particularly mustards, contributed significantly to that fuel load. However, there is evidence that fires of this scale occurred previously at the INEEL. The principal lineament is a linear feature on the INEEL landscape that extends $27.8 \mathrm{~km}$ (17.3 miles) to the northeast from Middle Butte (see Anderson et al. 1996). The principal lineament appears to be the eastern edge of a large fire scar, visible on aerial photographs, where wind-blown sediments accumulated. Confirmation that this landscape feature was indeed the result of a wildfire would be an important contribution to our understanding of the fire ecology of cold desert regions. It would document that the scale of recent fires is not unprecedented, and it would show that disturbances due to wildfire can have effects on shrub-steppe vegetation that persist for a very long time.

\section{Objectives}

The objectives of this study are to:

- Document postfire vegetation development on recent INEEL burn sites, with particular emphasis on understanding patterns of recruitment and the dynamics of filling gaps in the vegetal cover.

We predict that the postfire vegetation will be dominated by species that survived the fire and their offspring and that recruitment by other species will be rare except in areas immediately adjacent (i.e. $<50 \mathrm{~m}[160 \mathrm{ft}])$ to unburned areas. We also predict that colonization patterns during the first few postfire years will set the trajectories of long-term vegetation dynamics on the site. These results will provide a basis for predicting postfire vegetation dynamics at the INEEL.

- Investigate the hypothesis that the principal lineament resulted from a large wildfire.

To that end we determined the age of individual sagebrush plants on and around the principal lineament and searched for buried charcoal in the principal lineament. We are examining fire records and newspapers accounts from the area in an attempt to find written documentation of early fires at the INEEL.

\section{PROJECT ACCOMPLISHMENTS}

- In 1995 and 1996, we estimated plant cover data on plots established in 1980 by Floyd (1982), half of which were burned in the 1994 fire. Seedling densities also were recorded at each plot to document recruitment.

- Plant cover was estimated on three of the long-term vegetation plots (nos. 95, 96, \& 97) that were burned by the Butte City Fire in 1994.

- We established 10 new plots for assessing postfire vegetation development on the area burned by the 1995 ANL-W fire.

Plots were chosen based on the presence of cheatgrass and other exotic annuals to further study the role that cheatgrass and other exotics play in vegetation dynamics in the first few years after a wildfire. Plant cover and seedling densities were measured.

- Charcoal was collected from soil samples excavated from the principal lineament. A composite sample was submitted to Beta 
Analytical Inc. for radiocarbon dating. Results are expected in February 1997.

- Cross sections of big sagebrush stems were collected from areas on and adjacent to the principal lineament to estimate age by counting annual rings. Ages ranged from 26-33 years on the lineament, to $22-45$ years west of the lineament, and 27-42 years east of the lineament.

- Bureau of Land Management fire records and the newspaper, The Idaho Register, were searched for reports of a large fire that could have produced the principal lineament. No such evidence was found, but newspaper searches are not completed.

- We collected soil samples from near shrubs (shrub spaces) and from interspaces between shrubs in areas burned by the 1996 fire near ANL-W and adjacent unburned areas to compare nitrate and ammonia levels between burned and unburned soils before and after incubation in the laboratory.

\section{IMPORTANT RESULTS}

Postfire vegetation on plots burned by the 1994 Butte City Fire is dominated by native perennial species. However, cover of exotic annuals is higher on the burned sites than in adjacent unburned areas.

Total plant cover on the burned plots was nearly 5\% higher in 1996 than in 1995 and was $84 \%$ of that on adjacent unburned plots (Table 16). Exotic annuals contributed $27 \%$ of the cover on burned plots but less than $1 \%$ on control plots; most of this was due to Russian thistle (Salsola kali) and Jim Hill mustard (Sisymbrium altissimum). Cover of cheatgrass remained low and was lower on the burned site than on the control plots (Table 16). Green rabbitbrush (Chrysothamnus viscidiflorus) was the most abundant native perennial on the burned plots, and cover of perennial grasses more than doubled from that in 1995, totaling half that on the control plots.

Perennial grasses, forbs, and shrubs dominated the vegetative cover on all three burned, long-term vegetation plots. Hood's phlox (Phlox hoodii), long-leaved phlox (Phlox longifolia), and thick-spiked wheatgrass (Elymus lanceolatus), a native rhizomatous grass, were the most abundant perennial species. However, exotic annuals were the most abundant seedlings.

Cover of cheatgrass did not increase between 1995 and 1996 on new vegetation plots burned by the Butte City Fire.

Cheatgrass cover on these plots was insignificant, but more than half of the seedlings counted were exotic annuals, with cheatgrass being the most abundant. Salsify (Tragopogon dubius), the most abundant exotic, had $1.4 \%$ cover. Thick-spiked wheatgrass was the most abundant species, with $3 \%$ cover.

Nitrate levels were significantly higher in burned than in unburned samples analyzed immediately after collection, but there was no difference in nitrate concentrations between shrub spaces and interspaces at that time.

Nitrate levels increased markedly in all samples during incubations to determine nitrifying potential (Table 17). Post incubation analyses showed no difference in nitrate level between samples from burned and unburned areas, but shrub spaces had nearly twice the amount of nitrate than did interspaces.

As seen for nitrate, ammonia levels were higher in burned areas than in unburned areas before but not after incubation (Table 17).

There was no difference in ammonia levels between shrub spaces and interspaces before incubation, but post incubation samples from interspaces had higher ammonia levels in the interspaces than in the shrub spaces, contrary to expectations. Incubation did not result in a 
Table 16. Cover $(\%)$ of common plant species on the Floyd plots burned by the Butte City Fire in 1994.

\begin{tabular}{|c|c|c|c|c|}
\hline \multirow[b]{2}{*}{ Shrubs } & \multicolumn{2}{|c|}{ Burned Plots } & \multicolumn{2}{|c|}{ Control Plots } \\
\hline & 1995 & 1996 & 1995 & 1996 \\
\hline Artemisia tridentata & 0.00 & 0.02 & 10.69 & 9.68 \\
\hline Ceratoides lanata & 0.02 & 0.03 & 0.90 & 0.40 \\
\hline Chrysothamnus viscidiflorus & 10.23 & 9.81 & 7.61 & 7.41 \\
\hline Eriogonum microthecum & 0.00 & 0.00 & 0.10 & 0.05 \\
\hline Tetradymia canescens & 0.02 & 0.00 & 0.42 & 0.28 \\
\hline Total Shrub Cover & 10.27 & 9.86 & 19.72 & 17.82 \\
\hline \multicolumn{5}{|l|}{ Grasses } \\
\hline Agropyron cristatum & 0.01 & 0.05 & 0.90 & 0.03 \\
\hline Pseudoroegneria spicata & 0.39 & 0.72 & 3.84 & 5.21 \\
\hline Elymus lanceolatus & 0.17 & 0.52 & 0.13 & 0.41 \\
\hline Leymus cinereus & 0.53 & 0.81 & 0.00 & 0.00 \\
\hline Oryzopsis hymenoides & 0.17 & 0.53 & 1.59 & 1.54 \\
\hline Poa secunda & 0.02 & 0.15 & 0.08 & 0.69 \\
\hline Elymus elymoides & 0.68 & 1.49 & 0.24 & 0.43 \\
\hline Stipa comata & 0.04 & 0.13 & 0.53 & 0.08 \\
\hline Total Grass Cover & 2.00 & 4.35 & 6.41 & 8.36 \\
\hline \multicolumn{5}{|l|}{ Forbs } \\
\hline Astragalus convallarius & 0.10 & 0.05 & 0.13 & 0.02 \\
\hline Astragalus filipe & 0.12 & 0.01 & 0.10 & 0.10 \\
\hline Astragalus lentiginosus & 0.12 & 0.02 & 0.04 & 0.04 \\
\hline Crepis acuminata & 0.01 & 0.05 & 0.02 & 0.06 \\
\hline Phlox hoodii & 0.20 & 0.23 & 1.21 & 1.10 \\
\hline Schoenocrambe linifolia & 0.52 & 0.87 & 0.00 & 0.00 \\
\hline Sphaeralcea munroana & 0.04 & 0.42 & 0.00 & 0.00 \\
\hline Total Forb Cover & 1.11 & 1.65 & 1.50 & 1.32 \\
\hline \multicolumn{5}{|l|}{ Exotic Annuals and Biennials } \\
\hline Alyssum desertorum & 0.01 & 0.02 & 0.02 & 0.06 \\
\hline Bromus tectorum & $<.01$ & 0.02 & 0.08 & $<.01$ \\
\hline Descurainia sophia & 0.01 & 0.38 & $<.01$ & 0.01 \\
\hline Melilotus officinalis & 0.16 & 0.92 & $<.01$ & $<.01$ \\
\hline Salsola kali & 3.82 & 4.04 & $<.01$ & 0.10 \\
\hline Sisymbrium altissimum & 0.85 & 1.66 & 0.01 & $<.01$ \\
\hline Tragopogon dubius & $<.01$ & $<.01$ & 0.01 & $<.01$ \\
\hline Total Annual Cover & 4.86 & 7.10 & 1.02 & 0.20 \\
\hline Total Plant Cover & 18.24 & 22.96 & 28.65 & 27.70 \\
\hline
\end{tabular}


Table 17. Nitrate and ammonia concentrations ( $\mu \mathrm{g} \mathrm{N} / \mathrm{g}$ soil) for soils collected from near shrubs (shrub space) and from interspaces between shrubs on an area burned by the 1995 Argonne West fire and an adjacent unburned area. Initial values are for samples analyzed immediately after they were collected; final values are for samples incubated in the laboratory for six weeks. Statistical tests for $\mathrm{NH}_{4}$ and $\mathrm{NO}_{3}$ samples were performed on In-transformations for analysis of variance. Arithmetic means are reported in all cases.

\begin{tabular}{lcccc}
\hline & \multicolumn{2}{c}{ Nitrate } & \multicolumn{2}{c}{ Ammonia } \\
\cline { 2 - 5 } & Initial & Final & Initial & Final \\
\cline { 2 - 5 } Burned & 15.60 & 62.05 & 6.71 & 2.19 \\
Unburned & 1.38 & 55.43 & 1.51 & 1.08 \\
Shrub space & 8.58 & 74.26 & 3.45 & 0.88 \\
Interspace & 8.40 & 43.22 & 4.77 & 2.40 \\
\hline
\end{tabular}

\begin{tabular}{lcccc}
\hline & \multicolumn{2}{c}{ Nitrate } & \multicolumn{2}{c}{ Ammonia } \\
\cline { 2 - 5 } & Before & After & Before & After \\
\cline { 2 - 5 } & $<0.001$ & 0.53 & 0.003 & 0.32 \\
Burned vs. unburned & 0.41 & 0.005 & 0.07 & 0.037 \\
Shrub space vs. interspace & &
\end{tabular}

significant increase in ammonia concentration (Table 17).

The presence of charcoal buried within the principle lineament provides additional evidence this landscape feature is the result of a large wildfire.

\section{LITERATURE CITED}

Anderson, J. E., K. T. Ruppel, J. M. Glennon, K. E. Holte, and R. C. Rope. 1996. Plant communities, ethnoecology, and flora of the Idaho National Engineering Laboratory. ESRF-005, Environmental Science and Research Foundation. Idaho Falls, Idaho. Brown, D. E., and R. A. Minnich. 1986. Fire and changes in creosote bush scrub of the western Sonoran Desert, California. American
Midland Naturalist 116:411-422.

Cole, N. K. 1987. The growth and water relations of Leymus cinereus following a prescribed burn. MS Thesis. Idaho State University. (Pocatello, ID)

Floyd, D. A. 1982. A comparison of three methods for estimating vegetal cover in sagebrush steppe communities. MS Thesis. Idaho State University, (Pocatello, ID).

Hosten, P. E. and N. E. West. 1994.

Cheatgrass dynamics following wildfire on a sagebrush semidesert site in central Utah. Pages 56-62 in Proceedings - ecology and management of annual rangelands, S. G. Monsen and S.D. Kitchen (compilers) USDA Forest Service General Technical Report INT-GTR-313, Intermountain Research Station, Ogden, Utah. 
Houston, D. B. 1973. Wildfires in northern Yellowstone Park. Ecology 54:1111-1117.

Humphrey, D. L. 1984. Patterns and mechanisms of plant succession after fire on Artemisia-grass sites in southeastern Idaho. Vegetatio 57:91-101.

Klemmedson, J. O. and J. G. Smith. 1964. Cheatgrass (Bromus tectorum L.). Botanical Review 30:226-262.

Knapp, P. A. 1996. Cheatgrass (Bromus tectorum $\mathrm{L}$.) dominance in the Great Basin Desert - history, persistence, and influences to human activities. Global Environmental Change 6:37-52.

Noble, I. R., and R. O. Slatyer. 1980. The use of vital attributes to predict successional changes in plant communities subject to recurrent disturbances. Vegetatio 43:5-21.

Ratzlaff, T. D., and J. E. Anderson. 1995. Vegetal recovery following wildfire in seeded and unseeded sagebrush steppe. Journal of Range Management 48:386-391

West, N. E., and M. A. Hassan. 1985. Recovery of sagebrush-grass vegetation following wildfire. Journal of Range Management 38:131-134.
Whisenant, S. G. 1990. Changing fire frequencies on Idaho's Snake River Plains: ecological and management implications. Pages 4-10 in Proceedings - symposium on cheatgrass invasion, shrub die-off, and other aspects of shrub biology and management, E. D. McArthur, E. M. Romney, S. D. Smith, and P. T. Tueller, compilers. USDA Forest Service General Technical Report INT-276, Intermountain Research Station, Ogden, Utah.

Wright, H. A., and A. W. Bailey. 1982. Fire ecology. John Wiley and Sons, New York.

Wright, H. A., L. F. Neuenschwander, and C. M. Britton. 1979. The role and use of fire in sagebrush-grass and pinyon-juniper plant communities: A state-of-the-art review. USDA Forest Service General Technical Report INT-58, Intermountain Forest and Range Experiment Station, Ogden, Utah.

Young, J. A., and R. A. Evans. 1978. Population dynamics after wildfires in sagebrush grasslands. Journal of Range Management 31:283-289.

Young, J. A., R. A. Evans, and R. A. Weaver. 1976. Estimating the potential downy brome competition after wildfires. Journal of Range Management 29:322-325. 


\title{
OFFSITE TRANSPORT OF RADIONUCLIDES FROM INEEL FACILITIES BY, AND EFFECTS TO, BARN SWALLOWS
}

\author{
Ronald W. Warren ${ }^{28}$
}

\begin{abstract}
Research is being conducted to quantify barn swallow (Hirundo rustica) transport of radionuclides from waste sites via nest materials and from the INEEL within the barn swallows themselves. During 1996 we surveyed all buildings and structures in the TAN (TSF), TRA and ICPP facilities and recorded a total of 17 barn swallow nests at TRA, 44 at TAN (TSF), and 138 at ICPP. Of those nests, $65 \%$ at TRA, 50\% at TAN, and $44 \%$ at ICPP were being actively used. Over the past two years 40 dosimeters were placed in randomly selected nests, 10 at each site, each year. In 1995, average exposure rates were higher at TRA compared to those in nests at TAN, ICPP and control sites. In 1996 the total average exposure rates did not significantly differ between any of the sites, though one nest at TRA had an average daily exposure rate nearly twice that of the maximum measured in control nests. Five swallow nests were collected each from TAN, TRA, and ICPP facilities as well as from control sites in both 1995 and 1996. Results from nests collected in 1995 showed one nest from ICPP with significantly higher total concentrations of radionuclides compared to nests from control sites. This particular nest had a total concentration of $381 \mathrm{pCi} \mathrm{g}^{-1}$ compared with an average of 22 to $33 \mathrm{pCi} \mathrm{g}^{-1}$ for the remaining nests. Twenty five percent of the $381 \mathrm{pCi}^{-1}$ in the nest was from ${ }^{60} \mathrm{Co}$ and elevated ${ }^{60} \mathrm{Co}$ concentrations were found in at least one other nest at ICPP and two nests at TRA. Of five barn swallows collected from the TRA facility, all had higher total concentrations than control samples. The average concentration in the samples was $12.1 \mathrm{pCi} \mathrm{g}^{-1}$ (wet weight) with a range of 4.4 to $25.7 \mathrm{pCi} \mathrm{g}^{-1}$. The average concentration in control barn swallow samples was $2.4 \mathrm{pCi}^{-1}$.
\end{abstract}

Keywords: Barn swallows, radionuclides, Idaho Chemical Processing Plant, Test Area North, Test Reactor Area.

\section{JUSTIFICATION}

Barn swallows (Hirundo rustica) are common at most facilities on the INEEL and are known to nest near many wastewater ponds found on site (Halford and Millard 1978, Cieminski 1993). In a study conducted 1976 through 1978, barn swallows nesting at the Test Reactor Area were found to build nests with radionuclide contaminated materials and to accumulate radionuclides internally by ingesting arthropods from radioactive leaching ponds at TRA (Millard et al. 1990). Over 20 fission and activation products were detected in swallows at TRA which were responsible for an estimated dose rate to the birds of $0.2 \mathrm{mGy} \mathrm{d}^{-1}\left(22 \mathrm{mrad} \mathrm{d}^{-1}\right)$. Radionuclide concentrations in their nesting materials averaged $379 \mathrm{~Bq} \mathrm{~g}^{-1}\left(10,236 \mathrm{pCi} \mathrm{g}^{-1}\right)$ which related to mean external dose rates in the nests of about 400 times that in control nests located $100 \mathrm{~km}$ (62 mi) south of TRA. Though no obvious direct effects were found, the mere presence of the contamination in the birds is a sensitive public relations issue, especially because barn swallows are known to migrate to locations as distant as South America (Udvardy 1977).

Two plastic-lined ponds were constructed during the summer of 1993 to replace the leaching ponds at TRA and little is known about radionuclide cycling in a lined-pond system. With very little sediment present, at least initially, radionuclide behavior is likely different than in a non-lined percolation pond. Because of the small amounts of sediment, radionuclide concentrations in the sediment are likely to be higher, thereby potentially increasing the amounts transported in barn swallow nest materials.

Monitoring known movements of radionuclides in the environment is needed in order to ensure protection of health and the environment as required by DOE Orders. Measuring radionuclide concentrations in swallows at multiple facilities on the INEEL, as well as in their nests, will enable an estimate of radioactivity transported from waste areas and, in the case of the old TRA leaching ponds and new plastic-lined ponds,

${ }^{28}$ Environmental Science and Research Foundation, P.O. Box 51838, Idaho Falls, ID 83405-1838. 
allow for comparisons with past waste management practices. Also, because barn swallows are protected under the Migratory Bird Treaty Act, continued data is needed to ensure no harmful effects on these birds. These data can also be used in support of Ecological Risk Assessment.

\section{Objectives}

The specific objectives of this project are to:

- Quantify the radionuclide transport from waste sites via barn swallows and in nesting materials.

- Determine how much radioactive materials are being transported to facility buildings in nest materials.

- Compare transport from plastic-lined TRA waste ponds and previously used leaching ponds.

- Determine the exposure rates in swallow nests.

- Determine potential effects to swallow populations from the uptake and exposure to radionuclides as expressed by reproductive productivity.

\section{PROJECT ACCOMPLISHMENTS}

- In July we surveyed all buildings and structures in the TAN (TSF), TRA and ICPP facilities. All swallow nests were recorded and, where possible, it was determined whether each nest was actively being used.

- Forty dosimeters were placed in randomly selected nests, 10 each at TAN, TRA, ICPP, and control sites.

- A total of 20 barn swallow nests were collected for radiological analysis. Five swallow nests were collected each from TAN, TRA, and ICPP facilities as well as from control sites. Results were received from radiological analysis of 20 barn swallow nests collected during 1995.

- Five barn swallows were collected from the TRA facility. Each was sent for radiological analysis.

\section{IMPORTANT RESULTS}

A total of 17 barn swallow nests were recorded at TRA, 44 at TAN (TSF), and 138 at ICPP. Of those nests, $65 \%$ at TRA, $50 \%$ at TAN, and $44 \%$ at ICPP were being actively used. The average clutch sizes were $4.0(\mathrm{~s}=$ $1.0), 4.3(\mathrm{~s}=0.7), 3.2(\mathrm{~s}=1.4)$, and $4.6(\mathrm{~s}=$ $0.6)$ for active nests at TRA, TAN, ICPP, and control sites, respectively. Preliminary analysis found no significant difference in clutch size between any facility and control sites. The number of active nests at each site and average clutch sizes will be used to make population estimates.

Average exposure rates in nests are listed in Table 18. In 1995, average exposure rates were higher at TRA compared to those in nests at TAN, ICPP and control sites. In 1996 the average of measured exposure rates did not significantly differ between any of the sites, though one nest at TRA had an average daily exposure rate nearly twice that of the maximum measured in control nests. The highest measured exposure rate in any nest was $8.3 \mathrm{mR} \mathrm{d}^{-1}$ at TRA during 1995, a factor of about 26 times lower than the average exposure rate measured in previous research conducted in the late 1970 s by Millard et al. (1990)

Analysis results from the 20 barn swallow nests collected five each from TAN, TRA, ICPP, and control sites, showed one nest from ICPP with significantly higher total 
Table 18. Average exposure rates measured in barn swallow nests at various sites, 1995 and 1996.

\begin{tabular}{lcc} 
& \multicolumn{2}{c}{$\begin{array}{c}\text { Average exposure rate } \\
\mathrm{mR} \mathrm{d}^{-1}\end{array}$} \\
\cline { 2 - 3 } Nest Location & 1995 & 1996 \\
\hline Control & $0.5(\mathrm{~s}=0.05, \mathrm{n}=7)$ & $0.5(\mathrm{~s}=0.08, \mathrm{n}=7)$ \\
TRA & $2.2(\mathrm{~s}=3.5, \mathrm{n}=4)$ & $0.5(\mathrm{~s}=0.1, \mathrm{n}=6)$ \\
TAN & $0.5(\mathrm{~s}=0.08, \mathrm{n}=13)$ & $0.5(\mathrm{~s}=0.2, \mathrm{n}=9)$ \\
ICPP & $0.6(\mathrm{~s}=0.4, \mathrm{n}=13)$ & $0.4(\mathrm{~s}=0.04, \mathrm{n}=8)$ \\
\hline
\end{tabular}

concentrations of radionuclides compared to control nests. This one nest had a total concentration of $381 \mathrm{pCi} \mathrm{g}^{-1}$ compared with an average of 22 to $33 \mathrm{pCi} \mathrm{g}^{-1}$ for the remaining nests. Twenty five percent of the $381 \mathrm{pCi} \mathrm{g}^{-1}$ in this nest was from ${ }^{60} \mathrm{Co}$, and elevated ${ }^{60} \mathrm{Co}$ concentrations were found in at least one other nest at ICPP and two nests at TRA. The average concentration of nests at TRA measured in the late 1970s was about $10,200 \mathrm{pCi}^{-1}$, a factor of about 27 times more than our measured maximum.

All five barn swallows collected from TRA had higher total concentrations than control samples. The average concentration in TRA barn swallow samples was $12.1 \mathrm{pCi} \mathrm{g}^{-1}$ (wet weight) with a range of 4.4 to $25.7 \mathrm{pCi} \mathrm{g}^{-1}$. The average concentration in control barn swallow samples was $2.4 \mathrm{pCi} \mathrm{g}^{-1}$. Previous research conducted in the late 1970 s by Millard et al. (1990) showed average concentrations in adult barn swallows taken at TRA to be about $1,380 \mathrm{pCi} \mathrm{g}^{-1}$, a factor of about 54 to 314 times higher than those observed in 1996.

\section{PRODUCTS}

This project is in the data acquisition phase. No products have been produced as of this time.

\section{LITERATURE CITED}

Cieminski, K. L. 1993. Wildlife use of wastewater ponds at the Idaho National Engineering Laboratory. M.S. Thesis, South Dakota State University, Brookings. $311 \mathrm{pp}$.

Halford, D. K. and J. B. Millard. 1978. Vertebrate fauna of a radioactive leaching pond complex in southeastern Idaho. Great Basin Naturalist 38:64-70.

Millard, J. B., F. W. Whicker and O. D. Markham. 1990. Radionuclide uptake and growth of barn swallows nesting by radioactive leaching ponds. Health Physics 58:429-439.

Udvardy, M. D. F. 1977. The Audubon Society field guide to North America birds. Alfred A. Knopf, Inc., New York, NY. 


\title{
UPTAKE OF CONTAMINANTS BY VEGETATION AND BURROWING ACTIVITY ON A DECOMMISSIONED RADIOACTIVE WASTE POND COMPLEX
}

\author{
Ronald W. Warren ${ }^{29}$
}

\begin{abstract}
Research is being conducted to quantify contaminant uptake by vegetation and burrowing organisms on decommissioned radioactive waste ponds at the Test Reactor Area (TRA) on the Idaho National Engineering and Environmental Laboratory (INEEL). The three liquid radioactive waste leaching ponds, constructed in 1952, 1957, and 1964, received an estimated $53.5 \mathrm{kCi}$ of activity between 1952 and 1993 . All ponds were taken out of service in 1993 and two were closed in late 1993 and early 1994 with a soil cover containing no biobarriers to inhibit root infiltration or burrow penetration. Vegetation species and biomass were determined for those two pond covers, and samples of vegetation were analyzed for gamma-emitting radionuclides, ${ }^{90} \mathrm{Sr},{ }^{238} \mathrm{Pu},{ }^{239 / 240} \mathrm{Pu},{ }^{241} \mathrm{Am}$, and selected trace metals. Total radionuclide concentrations in the vegetation averaged $45.8 \pm 7.4 \mathrm{pCi} \mathrm{g}^{-1}$ for the 1952 pond cover, $23.5 \pm$ $5.9 \mathrm{pCi} \mathrm{g}^{-1}$ for the 1964 pond cover, and $16.4 \pm 4.6 \mathrm{pCi} \mathrm{g}^{-1}$ for control plots. Average concentrations in vegetation taken from the 1952 pond cover were $11.5,135$, and 66.5 times higher than those measured from control plots for ${ }^{60} \mathrm{Co}$, ${ }^{137} \mathrm{Cs}$, and ${ }^{90} \mathrm{Sr}$, respectively. Preliminary results of metal concentrations showed no differences between vegetation taken from the pond covers and control vegetation. All covers were also surveyed for burrowing activity. A total of 46 burrow sites were located on the 1964 pond cover, of which 15 were ant nests and 31 were small mammal burrows. On the 1952 pond cover, a total of 15 burrow sites were located, of which seven were ant nests and eight were small mammal burrows. The total amount of soil brought to the surface from all burrowing activity over the two years of the covers' existence was $337 \mathrm{~kg}$. Ant burrow activity accounted for a $158 \mathrm{~kg}$ on the 1964 pond cover and $51 \mathrm{~kg}$ on the 1952 pond cover, small mammal burrow activity accounted for $116 \mathrm{~kg}$ and $12 \mathrm{~kg}$ of soil being brought to the surface of the 1964 and 1952 pond covers, respectively. Radionuclide and metal concentration data from samples taken from excavated soils have not yet been analyzed. Uptake of radionuclides by vegetation is occurring across both the covers. Continued measurement and analysis of these processes are needed to determine their effects on the cover integrity.
\end{abstract}

Keywords: Burrow activity, landfill cover, plant uptake, radionuclides, Test Reactor Area, trace metals.

\section{JUSTIFICATION}

Three infiltration ponds were constructed at the Test Reactor Area (TRA) on the Idaho National Engineering and Environmental Laboratory (INEEL) between 1952 and 1964 to receive a wide assortment of low-level radioactive liquid wastes. Each pond is identified by the year of it's construction-1952, 1957, and 1964. The ponds, collectively known as the warm waste ponds, received radioactive effluent at an average discharge rate of $2,000 \mathrm{~m}^{3} \mathrm{~d}^{-1}$ from 1952 until their use was discontinued in 1993. Taylor (1994) estimated that approximately $53.5 \mathrm{kCi}$ of activity had been released to the ponds from 1952 through 1993, by far the largest amount released to effluent ponds on the INEEL. Not only were these waste ponds a concern due to the radioactive contamination, but large amounts of chromate were also disposed in the ponds prior to November 1964.

Much research had been conducted on various aspects of radionuclide cycling in the warm waste ponds and the topic is well understood (Ibrahim and Culp 1989, Millard 1986). Generally, radionuclides became bound with the sediments of the ponds, inhibiting the transport of large amounts of the contamination.

Early in 1993, use of the waste ponds was discontinued as required under DOE Order 5400.5. Effluent input ceased and the ponds were allowed to dry. The 1952 pond was backfilled with sediments from the 1964 pond, then covered with a $30-\mathrm{cm}(1-\mathrm{ft})$ thick clean soil cover. The 1964 pond was filled to grade with clean backfill then topped with a 15-cm (6-in) topsoil cover. The 1957 pond was filled with contaminated soil from other INEEL environmental remediation projects

\footnotetext{
${ }^{24}$ Environmental Science and Research Foundation, P.O. Box 51838, Idaho Falls, ID 83405-1838.
} 
but had not been capped as of the end of 1996.

The disturbed area on and surrounding the covers was revegetated with a mixture of native grasses but has since been fairly heavily colonized by three invader species: Russian thistle (Salsola kali), summer cypress (Kochia scoparia), and Jim Hill mustard (Sisymbrium altissimum). Root penetration into waste areas and plant uptake of radionuclides has been well documented at other sites (Arthur 1982, Johnson et al. 1994, Paine et al. 1979) with levels being recorded as high as $3.2 \times 10^{6} \mathrm{pCi} \mathrm{g}^{-1}$ of ${ }^{90} \mathrm{Sr}$ in Russian thistle at the Hanford site in Washington (Johnson et al. 1994). Vegetation uptake of radionuclides has been documented at the INEEL. In 1978, samples of crested wheatgrass (Agropyron cristatum) and Russian thistle taken from the RWMC showed significantly higher concentrations of ${ }^{238} \mathrm{Pu},{ }^{239 / 240} \mathrm{Pu}$, and ${ }^{241} \mathrm{Am}$ compared to plants from control sites (Arthur 1982). Rooting depths of many plant species, especially Russian thistle, are known to extend over one meter (3.3 ft) into the soil (Abbott 1989, Reynolds 1990) especially if there is available water as in the soils beneath these waste ponds.

Small mammals and ants have been known to burrow into hazardous waste covers (Blom 1990, O'Farrell and Gilbert 1975, Sejkora 1989). On the INEEL, it was also found that radionuclide concentrations in ant nests surrounding the warm waste ponds at TRA were significantly higher than surrounding soils (Blom 1990). The specific source of the radionuclides was thought to be the warm waste ponds but the mode of transport to the ant nests was not clear. Because these ant nests were some distance from the ponds, their source could have been either from below the burrows, lateral spread of contaminants in the soil, or ants physically carrying contaminated soil from the ponds across the surface. Paul Blom (personal communication) witnessed this activity on one occasion. Because there was transport to the ant nests some distance from the ponds, burrowing activity in the area surrounding the waste ponds must be examined.

The current pond cover is an Interim Action under CERCLA (EG\&G 1994). Quantification of the magnitude of radionuclide uptake will help DOE, the requlators, and the public select the final cover design. In addition, specific cleanup criteria were established for these sites based on anticipated future use plans (EG\&G 1994). In order to predict the level of success of the remediation activities, data are needed on contaminant redistribution.

\section{OBJECTIVES}

The specific objectives of this research are to:

- Determine the extent and magnitude of radionuclide uptake by vegetation on the covers.

- Determine the extent and magnitude of radionuclide transport to the surface of the covers by burrowing animals.

- Predict future exposure rates and surface contamination levels based on measured uptake and redistribution of radionuclides.

- Determine heavy metal concentration in vegetation and soil on the covers.

- Determine potential doses to burrowing small mammals.

\section{PROJECT ACCOMPLISHMENTS}

- Vegetation species and biomass were determined for the 1964 and 1952 pond covers.

The vegetation on $141-\mathrm{m}^{2}$ randomly located plots were clipped on each cover. 
Species were separated, identified, and biomass determined. Five $1-\mathrm{m}^{2}\left(10.9 \mathrm{ft}^{2}\right)$ plots were also clipped at a control site approximately three miles northwest of TRA.

- Sixty-nine samples of vegetation were analyzed for gamma-emitting radionuclides; 38 of those samples were analyzed for ${ }^{90} \mathrm{Sr},{ }^{238} \mathrm{Pu},{ }^{239 / 240} \mathrm{Pu}$, and ${ }^{241} \mathrm{Am}$. All 69 samples were also analyzed for the metals arsenic, barium, cadmium, chromium, lead, selenium, and silver. Sixteen of the vegetation samples were analyzed for mercury.

- All covers were surveyed for burrowing activity. The specific location of all burrows were recorded and all soil brought to the surface was weighed.

- A total of 58 samples of excavated soil were analyzed for concentration of gamma-emitting radionuclides; 18 of them were analyzed for ${ }^{90} \mathrm{Sr},{ }^{238} \mathrm{Pu},{ }^{239240} \mathrm{Pu}$, and ${ }^{241} \mathrm{Am}$. All of the 58 soil samples were also analyzed for the metals arsenic, barium, cadmium, chromium, lead, selenium, and silver. Sixteen of the soil samples were analyzed for mercury.

\section{IMPORTANT RESULTS}

Species composition and average biomass for both the 1952 and 1964 covers and the control plots are listed in Table 19. A total of seven different plant species were identified growing on the 1952 pond cover and a total of 13 plant species were identified growing on the 1964 pond cover. Because the revegetation seed mix for the covers consisted predominately of crested wheatgrass, it is not surprising that crested wheatgrass had the highest average biomass on both the 1952 and 1964 pond covers. The invading weed species, summer cypress and Russian thistle, both ranked in the top four for highest average biomass on both covers. This is important because the root depth of these species have been documented to reach depths of about two meters (Klepper et al. 1985), well into contaminated soils beneath the topsoil covers.

Total radionuclide concentrations in the vegetation averaged $45.8 \pm 7.4 \mathrm{pCi} \mathrm{g}^{-1}$ for the 1952 pond cover, $23.5 \pm 5.9 \mathrm{pCi} \mathrm{g}^{-1}$ for the 1964 pond cover, and $16.4 \pm 4.6 \mathrm{pCi} \mathrm{g}^{-1}$ for the control plots. Average concentrations for particular radionuclides of interest are listed in Table 19, Table 20. Average concentrations in vegetation from the 1952 pond cover were $11.5,135$, and 66.5 times higher than those measured from control plots for ${ }^{60} \mathrm{Co},{ }^{137} \mathrm{Cs}$, and ${ }^{90} \mathrm{Sr}$, respectively.

Preliminary results of metal concentrations showed no differences between vegetation taken from the pond covers and control vegetation.

A total of 46 burrow sites were located on the 1964 pond cover; 15 ant nests and 31 small mammal burrows. On the 1952 pond cover, a total of 15 burrow sites were located; seven ant nests and eight small mammal burrows. The ant nests were located around the periphery of both covers while the small mammal burrows were located throughout the cover surfaces. The reason for this distribution is probably due to the slower expansion of ant nests onto the two-year-old pond covers. Small mammal burrow densities were lower on the 1952 pond cover by a factor of almost three while ant nest densities were only slightly lower. This is likely due to a larger amount of gravel in the soil on the surface of the 1952 pond cover. Data will be collected to quantify soil differences on the two covers. Ant burrow activity accounted for a total of $209 \mathrm{~kg}$ of soil being brought to the surface- $158 \mathrm{~kg}$ on the 1964 pond cover and $51 \mathrm{~kg}$ on the 1952 pond cover. Small mammal burrow activity accounted for a total of $116 \mathrm{~kg}$ of soil being brought to the surface of the 1964 pond cover and $12 \mathrm{~kg}$ of soil being brought to the surface of the 1952 pond cover. The total amount of soil brought to the surface from all burrowing activity over the 
Table 19. Average dry biomass per square meter for species found growing on the soil covers of the 1964 and 1952 TRA percolation ponds and on control plots.

\begin{tabular}{lccc}
\hline & \multicolumn{3}{c}{ Average Dry Biomass } \\
\cline { 2 - 4 } (g m & \multicolumn{3}{c}{ ) } \\
\cline { 2 - 4 } Plant Species & $\begin{array}{c}1952 \text { Pond } \\
\text { Cover }\end{array}$ & $\begin{array}{c}1964 \text { Pond } \\
\text { Cover }\end{array}$ & $\begin{array}{c}\text { Control } \\
\text { Plots }\end{array}$ \\
\hline Crested wheatgrass (Agropyron cristatum) & 69 & 48 & 92 \\
Russian thistle (Salsola kali) & 32 & 9.4 & 52 \\
Summer cypress (Kochia Scoparia) & 24 & 19 & 0.0 \\
Thick-spiked wheatgrass (Agropyron dasystachyum) & 4.0 & 0.6 & 16 \\
Jim Hill mustard (Sisymbrium altissimum) & 11 & 2.1 & 3.7 \\
Unknown grass & 3.8 & 0.2 & 3.4 \\
Desert alyssum (Alyssum desertorum) & 0.0 & 10.2 & 0.8 \\
Blue-bunch wheatgrass (Agropyron spicatum) & 0.0 & 0.1 & 7.6 \\
Green rabbit-brush (Chrysothamnus viscidiflorus) & 0.1 & 0.3 & 6.9 \\
California bromegrass (Bromus carinatus) & 0.0 & 0.0 & 5.3 \\
Halogeton (Halogeton glomeratus) & 0.0 & 4.1 & 0.0 \\
Indian ricegrass (Oryzopsis hymenodies) & 0.0 & 2.8 & 0.0 \\
Cheatgrass (Bromus tectorum) & 0.1 & 0.2 & 0.0 \\
Bottlebrush squirreltail (Elymus elymodies) & 0.0 & 0.1 & 0.0 \\
Clasping peppergrass (Lepidium perfoliatum) & 0.0 & 0.1 & 0.0 \\
Unknown forbs & 0.0 & 0.1 & 0.0 \\
\hline
\end{tabular}

two years of both covers' existence was 337 $\mathrm{kg}$. Radionuclide and metal concentration data from samples taken from excavated soils have not been analyzed as of this time.

\section{PRODUCTS}

This project is currently in the data collection phase. No products have been produced to date.

\section{LITERATURE CITED}

Abbott, M. L. 1989. Root profiles of six cold desert plant species determined by radioiodine uptake. M. S. Thesis, Colorado State University, Ft. Collins. $98 \mathrm{pp}$.

Arthur, W. J. 1982. Radionuclide concentrations in vegetation at a solid radioactive waste-disposal area in southeastern Idaho. Journal of Environmental Quality 11:394-399.

Blom, P. E. 1990. Potential impacts on radioactive waste disposal situations by the harvester ant, Pogonomyrmex salinus Olsen (Hymenoptera: Formicidae). M. S. Thesis, University of Idaho, Moscow. $241 \mathrm{pp}$.

EG\&G, Inc. 1994. Draft remedial action report, Test Reactor Area warm waste pond interim action, Operable Unit (OU) 2-10. Document No. 02.010.2.1.209.01. Ibrahim, S. and T. Culp. 1989. Plutonium distribution and oxidation states in a reactor leaching pond system. Health Physics 57:607-614. 
Table 20. Average concentrations of selected radionuclides in vegetation growing on the soil covers of the 1964 and 1952 TRA percolation ponds and on control plots.

Average Radionuclide Concentrations

\begin{tabular}{lccc} 
& \multicolumn{3}{c}{$\left(\mathrm{pCi} \mathrm{g}^{-1}\right)$} \\
\cline { 2 - 4 } Location & ${ }^{60} \mathrm{Co}$ & ${ }^{137} \mathrm{Cs}$ & ${ }^{90} \mathrm{Sr}$ \\
\hline 1952 Pond Cover & 0.46 & 2.7 & 17.3 \\
1964 Pond Cover & 0.13 & 0.13 & 0.7 \\
Control Plots & 0.04 & 0.02 & 0.26 \\
\hline
\end{tabular}

Johnson, A. R., B. M. Markes, J. W. Schmidt, A. N. Shah, S. G. Weiss, K. J. Wilson. 1994. Historical records of radioactive contamination in biota at the 200 areas of the Hanford site. WHC-MR-0418. Westinghouse Hanford Company, Richland, WA.

Klepper, E. L., K. A. Gano, L. L. Cadwell. 1985. Rooting depth and distributions of deep rooted plants in the 200 area control zone of the Hanford Site. PNL-5247. Pacific Northwest Laboratory, Richland, WA.

Millard, J. B. 1986. Seasonal distribution and uptake of gamma emitting radionuclides of the Test Reactor Area leaching ponds. $\mathrm{Ph}$. D. Dissertation, Colorado State University, Ft. Collins. $191 \mathrm{pp}$.
O'Farrell, T. P. and R. O. Gilbert. 1975. Transport of radioactive materials by jackrabbits on the Hanford reservation. Health Physics 29:9-15.

Paine, D., K. R. Price, R. M. Mitchell. 1979. Evaluation of a decommissioned radwaste pond. RHO-SA-99. Rockwell International Corporation, Richland, WA.

Reynolds, T. D. 1990. Root mass and vertical root distribution of five semi-arid plant species. Health Physics 58:191-197.

Sejkora, K. J. 1989. Influence of pocket gophers on water erosion and surface hydrology. Dissertation Thesis, Colorado State University, Ft. Collins. 144 pp.

Taylor, K. A. 1.994. Radioactive waste management information for 1993 and record-to-date. DOE/ID-10054(93). U. S. Department of Energy, Idaho Operations Office, Idaho Falls, ID. 


\title{
ECOLOGICAL IMPACTS OF IRRIGATING NATIVE VEGETATION WITH SEWAGE WASTEWATER
}

\author{
Roger D. Blew and Randall C. Morris ${ }^{30}$
}

\begin{abstract}
The objectives of this project are to investigate the effects of land application of sewage wastewater on sagebrush steppe vegetation. Sampling points were identified in three different plant community types in the irrigated and nearby control areas. Installation of soil moisture measurement equipment was completed and data collection initiated. Samples for trace metals were collected and analysis is underway. Baseline vegetation surveys that compare irrigated to non-irrigated control areas were completed. Differences between the three community types was demonstrated by patterns of crested wheatgrass and green rabbitbrush cover. There are indications of differences in cover for some cover types between the irrigated and control treatments. It is unclear if these differences are due to the treatment or differences inherent between these areas prior to irrigation.
\end{abstract}

Keywords: Irrigation, sagebrush steppe, sewage wastewater, soil moisture, vegetation dynamics.

\section{JUSTIFICATION}

Disposal of wastewater is a necessity common to most municipal and industrial wastewater treatment facilities. In 1995, the INEEL began disposing of treated wastewater by applying it to the surface of soils and native vegetation using a center pivot irrigation system. Research conducted on this disposal method at the INEEL provides an opportunity to determine the benefits and/or hazards of disposal of wastewater on native vegetation in arid and semi-arid regions. Results will be applicable to a wide range of municipal, industrial and agricultural wastewater disposal needs. Because subsequent permits to dispose of water from agricultural facilities may have restrictions on water application to prevent deep percolation, this research program may refine some of the models used to predict the maximum rate of wastewater application possible without subsequent deep percolation.

The wastewater land application facility at CFA covers approximately 29.5 ha (73 acres). The permit for operating this system limits the application rate to $63.5 \mathrm{~cm}$ ( $25 \mathrm{in}$.) of water per year which must be applied such that no more than $7.6 \mathrm{~cm}$ ( $3 \mathrm{in}$.) of water leach through the root zone toward groundwater. The 63.5-cm- (25-in.-) maximum application rate is more than two and one-half times the average annual precipitation and plants may not be able to deplete this in one growing season to prevent leaching. Most of the precipitation in this cool desert biome comes in the winter and spring. Soil moisture recharge occurs in the spring with snowmelt and rainfall. Wastewater application must be timed to avoid this spring recharge period to further avoid deep percolation of wastewater.

The wastewater contains organic carbon, nitrogen and other nutrient elements, and trace metals that may have large impacts on the proper functioning of native soil-plant systems. The wastewater application represents up to 24-32 lbs of nitrogen added per acre per year. This is equivalent to the annual rate of nitrogen addition from air pollution believed to be partly responsible for forest decline in the northeastern U.S. and in northern Europe.

Different plant species respond differently to the addition of water and nutrient elements, especially if those additions come at times of the year that are normally dry. These differences in response can result in the growth of some species being favored and others discouraged and changes in plant community structure can be expected. For example, in studying the transition from Great Basin to Great Plains, Cook and Irwin (1992)

\footnotetext{
${ }^{30}$ Environmental Science and Research Foundation, P.O. Box 51838, Idaho Falls, ID 83405-1838.
} 
found that grasses dominate in areas where most precipitation came during the summer and shrubs dominated where most moisture came as winter snow. Summer irrigation may lead to decreases in shrub dominance and an increase in grasses.

Changes in the plant community mean changing habitats for other organisms such as small mammals, birds, insects and big game animals. Because the area is relatively small, it is unlikely that decreased habitat quality would have a significant impact on wildlife populations on the INEEL. Increases in habitat quality, however, could have substantial impacts on wildlife use patterns of this small area.

Pronghorn and elk have increasingly been responsible for substantial crop and forage depredation on private agricultural lands adjacent to the INEEL. This is a common problem in Idaho and in most western states. If data from this study show an increase in big game use of the treated area, using wastewater application on native vegetation to improve habitat away from valuable agricultural commodities may provide a means to reduce depredation problems.

\section{Objectives}

Objectives for this program are to:

- Determine changes in vegetation due to land application of wastewater.

- Determine changes in wildlife populations due to land application of wastewater.

- Determine trace metal contamination of the environment due to land application of wastewater.

- Quantify water movements in the soil and predict amounts of deep percolation from the land application of wastewater.

The specific objectives for 1996 were to:
- Establish study plots.

- Install and begin monitoring soil moisture measuring equipment.

- Establish and begin monitoring permanent vegetation transects.

- Sample vegetation for trace metals.

\section{PROGRAM ACCOMPLISHMENTS}

- Established study plots and sampling points in three distinct plant community types within the irrigated area.

Those communities include sagebrush steppe, a crested wheatgrass (Agropyron cristatum) dominated community, and a transition area between the two. The transition area has characteristics of the other two communities and appears to be an area of native sagebrush steppe that is being invaded by crested wheatgrass. Sampling locations were stratified based on these three communities and the number of sampling locations within each stratification were area weighted. Areas adjacent to the circle and contiguous with the three plant community types were used as non-irrigated controls. Sampling locations in the control areas were based on the same stratification scheme used in the irrigated area. Twenty sampling points were assigned in the irrigated area and a like number in the control area.

- At each of these points, a neutron hydroprobe access tube was installed.

These tubes are used for determining soil moisture at $20-\mathrm{cm}$ intervals extending down to bed rock or to a maximum depth of $2.0 \mathrm{~m}$. Soil moisture monitoring was initiated in the fall of 1996.

- Vegetation surveys were conducted at each of the sampling points. 
The vegetation surveys included determining percent cover using point frames (Floyd and Anderson 1982). At each point, five frames were counted along a transect beginning at the access tube and extending 10 $\mathrm{m}$ (33 ft.) toward the center of the circle.

- Samples of green rabbitbrush (Chrysothamnus viscidiflorus) and crested wheatgrass were collected for chemical analysis.

These samples were collected in a manner compatible with similar sampling for a project on mule deer on the INEEL (see p. 94). Those samples were sent to the University of Idaho for analysis. Results from those analyses are expected to be available in 1997.

\section{IMPORTANT RESULTS}

Soil moisture data includes the period following termination of irrigation in the fall. The results represent only a brief portion of the water year and are insufficient to report properly at this time.

Data collected on vegetation cover demonstrate the differences between the three plant community types upon which the stratifications were based. This difference is most apparent in the differences in cover of crested wheatgrass and green rabbitbrush between the three community types (Table 21). Crested wheatgrass had more than 30 percent cover in the crested wheatgrass community, 13 to 18 percent cover in the transition community and 0 to 2 percent in the sagebrush steppe community. Conversely, green rabbitbrush generally shows the opposite trend. The differences between community types are also evident in differences in species richness. The sagebrush steppe had 11 species represented in the survey, the irrigated and non-irrigated transition communities had nine and six species respectively, and the crested wheatgrass zone had three plant species in the irrigated and only one species in the control.

Some differences between irrigated and control areas are suggested by the cover data. Big sagebrush (Artemisia tridentata) was lower, moss was higher, and litter was lower in the irrigated than in the control. It is unclear whether these differences are due to the irrigation treatment during only two growing seasons or if they are simply due to differences present before irrigation treatments began. If these differences become greater during the coming years, then an effect due to the irrigation treatment could be concluded. If the differences remain constant, then the differences are probably inherent to the different sites and not due to irrigation. The differences in litter cover could be due to higher decomposition rates associated with irrigation. It is possible that such treatment effects could be present after only two growing seasons. This will be tested with artificial substrate decomposition experiments.

\section{PRODUCTS}

Since 1996 was the first year of this project, no papers or reports have been produced.

\section{LITERATURE CITED}

Cook, J. G. and L. L. Irwin. 1992. Climatevegetation relationships between the Great Plains and Great Basin. American Midland Naturalist 127:316-326.

Floyd, D. A. and J. E. Anderson. 1982. A new point interception frame for estimating cover of vegetation. Vegetatio 50:185-186. 
Table 21. Vegetation percent cover in the three different plant communities irrigated with wastewater and similar control areas.

\begin{tabular}{|c|c|c|c|c|c|c|c|}
\hline & \multirow[b]{2}{*}{ Species } & \multicolumn{2}{|c|}{ Sagebrush steppe } & \multicolumn{2}{|c|}{ Transition } & \multicolumn{2}{|c|}{ Crested wheatgrass } \\
\hline & & Irrigated & Control & Irrigated & Control & Irrigated & Control \\
\hline crested wheatgrass & Agropyron cristatum & 1.89 & 0.00 & 17.94 & 13.02 & 34.07 & 30.55 \\
\hline big sagebrush & Artemisia tridentata & 1.61 & 4.28 & 5.00 & 9.52 & 0.00 & 0.00 \\
\hline cheatgrass & Bromus tectorum & 0.05 & 0.50 & 10.00 & 0.00 & 0.00 & 0.00 \\
\hline green rabbit-brush & Chrysothamnus viscidiflorus & 15.94 & 13.06 & 11.11 & 11.03 & 1.11 & 0.00 \\
\hline tansymustard & Descaurainia sophi & 3.83 & 2.11 & 1.43 & 0.00 & 0.00 & 0.00 \\
\hline squirreltail & Elymus elymoides & 8.56 & 9.17 & 1.67 & 0.24 & 0.00 & 0.00 \\
\hline thickspike wheatgrass & Elymus laceolatus & 1.17 & 0.00 & 0.00 & 0.00 & 0.00 & 0.00 \\
\hline broom snakeweed & Gutierrezia sarothrae & 0.00 & 0.00 & 0.40 & 0.00 & 0.00 & 0.00 \\
\hline ballhead gilia & Ipomopsis congesta & 1.94 & 1.06 & 0.00 & 0.00 & 0.00 & 0.00 \\
\hline winterfat & Krascheninnikovia lanata & 0.00 & 0.00 & 0.00 & 1.27 & 0.00 & 0.00 \\
\hline prickly lettuce & Lactuca serriola & 0.05 & 0.00 & 0.00 & 0.00 & 0.00 & 0.00 \\
\hline Great Basin wildrye & Leymis cinerus & 0.00 & 1.22 & 0.00 & 0.00 & 0.00 & 0.00 \\
\hline prickly pear cactus & Opuntia polycantha & 0.00 & 0.06 & 0.00 & 0.00 & 0.00 & 0.00 \\
\hline western wheatgrass & Pascopyrum smithii & 0.00 & 2.56 & 0.00 & 0.56 & 0.00 & 0.00 \\
\hline tumbleweed mustard & Sisymbrium altissimum & 0.17 & 9.61 & 2.62 & 0.00 & 1.11 & 0.00 \\
\hline horsebrush & Tetradymia canescens & 1.28 & 0.55 & 0.00 & 0.00 & 0.00 & 0.00 \\
\hline penny-cress & Thlaspi arvense & 0.00 & 0.00 & 0.00 & 0.00 & 0.00 & 0.00 \\
\hline salsify & Tragopogon dubius & 0.05 & 0.00 & 0.24 & 0.00 & 0.00 & 0.00 \\
\hline litter & & 25.00 & 37.33 & 26.82 & 39.05 & 44.26 & 54.63 \\
\hline bare ground & & 20.05 & 16.17 & 13.49 & 27.62 & 15.74 & 3.89 \\
\hline dead shrub & & 17.78 & 19.50 & 19.60 & 9.84 & 1.81 & 12.04 \\
\hline lichen & & 0.94 & 1.89 & 0.87 & 1.11 & 0.00 & 0.00 \\
\hline moss & & 9.11 & 3.22 & 6.90 & 2.70 & 0.37 & 0.93 \\
\hline rock & & 0.00 & 0.39 & 1.59 & 0.00 & 0.19 & 0.00 \\
\hline
\end{tabular}




\title{
NOXIOUS AND EXOTIC WEED SURVEY OF THE IDAHO NATIONAL ENGINEERING AND ENVIRONMENTAL LABORATORY
}

\author{
Roger D. Blew ${ }^{31}$
}

\begin{abstract}
The close link between land use change and biological invasions has resulted in long-term ecological problems for many rangeland areas in the western United States. These invasions have brought about changes in the dominant vegetation in many rangeland types in the West. Conversion of shrublands to annual grasses is perhaps the most widespread of these invasions. Some weed species have been designated as "noxious" by law. Federal law (Title 7, Chapter 61) prohibits interstate movement of noxious weeds and Idaho State law (Title 6, Chapter 22) controls the transport of noxious weeds on any pubic roadway. Surveys on the Idaho National Engineering and Environmental Laboratory (INEEL) indicated the presence of six species listed as noxious weeds in Idaho. Distribution of most of those species on the INEEL was limited to highly disturbed areas and to invasion corridors. This suggested that these species may be relatively new to the INEEL. One species, musk thistle (Carduus nutans), has become wide spread and can be found across a large portion of the INEEL. It was also most likely a recent invader, but likely its wind-blown seeds have accessed a large area in a short time.
\end{abstract}

Keywords: Biological invasions, cheatgrass, exotic plants, musk thistle, noxious weeds, spotted knapweed.

\section{JUSTIFICATION}

Weeds are generally defined as any plant growing where it is not wanted. This means weeds are not necessarily defined by what species they are but rather by where they are growing. A plant that is an undesirable weed in one location may be quite acceptable growing somewhere else. In an agricultural setting, a weed may be any plant other than the intended crop. In native plant communities like the sagebrush steppe, any plant that is an exotic species, one not native to the region, can be considered as a weed.

The biological invasions caused by some weed species have resulted in significant economic losses. Because of these economic impacts certain weed species have been designated as "noxious" by state and federal law. Federal law (Title 7, Chapter 61) prohibits the movement of noxious weeds into the United States or across state boundaries. Idaho State law (Title 6, Chapter 22) requires that no article be moved from a place infested with noxious weeds onto a public roadway without first acting to prevent the spread of noxious weeds by that article, and no article containing noxious weed propagules may be sold or furnished to any person within the state. Federal agencies are bound by these laws and must control all noxious weeds that occur on federal land. Conducting surveys to locate any invasions is the first step in controlling weedy species.

It has been suggested that only land use change has caused more extinctions than have biological invasions (D'Antonio and Vitousek 1992). Unfortunately, biological invasion is closely linked to land use change. The effects of these human-caused biological invasions are long term. The ecological impacts caused by the breakdown of biogeographic barriers and the establishment of self-maintaining populations in areas where they would not normally have reached may take hundreds to thousands of years to reverse (D'Antonio and Vitousek 1992).

The introduction of non-native plant species combined with changing land use practices has brought about changes in the dominant vegetation in many rangeland types in the West. Perhaps the most significant of these changes has been the conversion of shrublands to annual grass range (D'Antonio and Vitousek 1992). Cheatgrass (Bromus tectorum) is the most widely recognized weed problem in the West. Hitchcock and Cronquist (1973) suggested that cheatgrass

\footnotetext{
${ }^{31}$ Environmental Science and Research Foundation, P.O. Box 51838, Idaho Falls, ID 83405-1838
} 
may be the most common grass in the Pacific Northwest. Its appearance, along with Russian thistle (Salsola kali), has changed the fire frequency in many rangeland regions such that sagebrush cannot become reestablished following fire. Native bunchgrasses cannot successfully compete with cheatgrass or Russian thistle and are also usually lost from the plant community. Although these species are not listed as noxious weeds, it remains important to evaluate their distribution on the INEEL because of the ecosystem-level effects that can result from these invasions.

In addition to cheatgrass and Russian thistle, several regulatory noxious weeds can be found on the INEEL. Many of the noxious weeds listed for the western United States of are of concern primarily to rangelands. A number of these species, particularly leafy spurge (Euphorbia esula) and the knapweeds (Centaurea spp.) have taken over large areas of rangeland in the West.

\section{Objectives}

The objective of this project is to examine the distribution of exotic plant species on the INEEL. Primary consideration is given to regulatory noxious weeds. Specific objectives for 1996 were to conduct surveys in areas previously known be infested by noxious weeds to confirm their presence, areas suspected to have noxious weeds, and areas that could be at risk of noxious weed invasion.

\section{ACCOMPLISHMENTS}

- Field surveys were conducted in areas previously reported to have noxious weeds present and in areas that could be infested.

Many noxious weeds and other invasive species are known to make initial invasions by being brought into the area on animals, vehicles, flowing water, or similar means. Corridors for their movement are likely areas to contain weeds. On the INEEL, these corridors include the Big Lost River and Birch Creek Diversion and all roads and highways, including the T-roads. Areas of soil disturbance along these corridors are especially vulnerable to invasion. Primary focus during 1996 was on the more commonly used two-track roads and disturbed areas such as abandoned gravel yards and on recovering burned areas.

The principle survey method used was based on those used for rare plant surveys. This involved visual inspection of those areas where weeds were suspected, likely to occur, or considered to be at risk. These area were primarily invasion corridors such as roads and rivers, and burned areas.

- Where target weed species were observed, a intensive localized search was conducted to determine the areal extent of the invasion and additional data about the plant community in the area were collected.

Those data included species richness, relative dominance and cover. Information about soil texture was also collected at these sites.

- A second type of survey tool used were incidence reports in which only the location and size of an infested area were noted.

These reports came primarily from other Foundation staff working in the field.

Although this survey data does not have the supporting data collected at the other survey locations, they are important in establishing the extent of weed invasions at the landscape scale. 


\section{IMPORTANT RESULTS}

Surveys conducted during 1996 of noxious weeds indicated localized infestations of several species and one species appeared frequently across a large portion of the INEEL. Localized infestations of spotted knapweed (Centaurea maculosa) were found in association with highly disturbed areas including the top of East Butte, a road gravel yard located at the intersection of Highways 22 and 28 , and at an abandoned gravel yard about $1.6 \mathrm{~km}$ (one mile) north of Highway 20-26 just east of Highway 33 (Fig. 29). Infestations of field bindweed (Convolvulus arvense) were found in a disturbed area east of Circular Butte and on a gravel bar in the middle of the Big Lost River about $1.6 \mathrm{~km}$ (one mile) upstream of the Spreading Area diversion (Fig. 29). In the same general area along the Big Lost River, two small populations of leafy spurge (Euphorbia esula) were found (Fig. 29). A single specimen of black henbane (Hyoscyamus niger) was found in Spreading Area A. Canada thistle (Cirsium arvense) was found at Spreading Area B, along the Big Lost River near the sinks, on the Birch Creek Diversion, and along T-4 (Fig. 29). These species are either localized infestations or in most cases represented by only one to a few specimens.

Musk thistle (Carduus nutans) was found in a number of areas across the southern and eastern part of the INEEL (Fig. 30). It was found in the Spreading Areas, in the area south and east of East Butte, along the Taylor Boulevard (Argonne access road), and in numerous locations in the area between T-17 and the east boundary of INEEL. Many of the infestations appeared to be relatively recent as evidenced by the lack of dead stems from previous years. In some areas, especially those in the vicinity of East Butte, the same sort of evidence suggested the infestations are at least four-years old. Many of the infestations were associated with roads, suggesting the significance of vehicular traffic in spreading seeds. However, many of what appeared to be more recent infestations were found some distance from roads, indicating the ability of these to spread easily by windblown seed. The sighting locations of musk thistle were probably only a representation of the possible distribution on the INEEL. Musk thistle can probably be found across the proposed distribution outlined on Fig. 30.

\section{PRODUCTS}

Since 1996 was the first year of this project, no papers or reports were produced.

\section{LITERATURE CITED}

D'Antonio, C. M. and P. M. Vitousek. 1992. Biological invasions by exotic grasses, the grass/fire cycle, and global change.

Annual Review of Ecology and Systematics 23:63-87.

Hitchcock, C. L. and A. Cronquist. 1973. Flora of the Pacific Northwest. University of Washington Press, Seattle, Washington. 730 pp. 


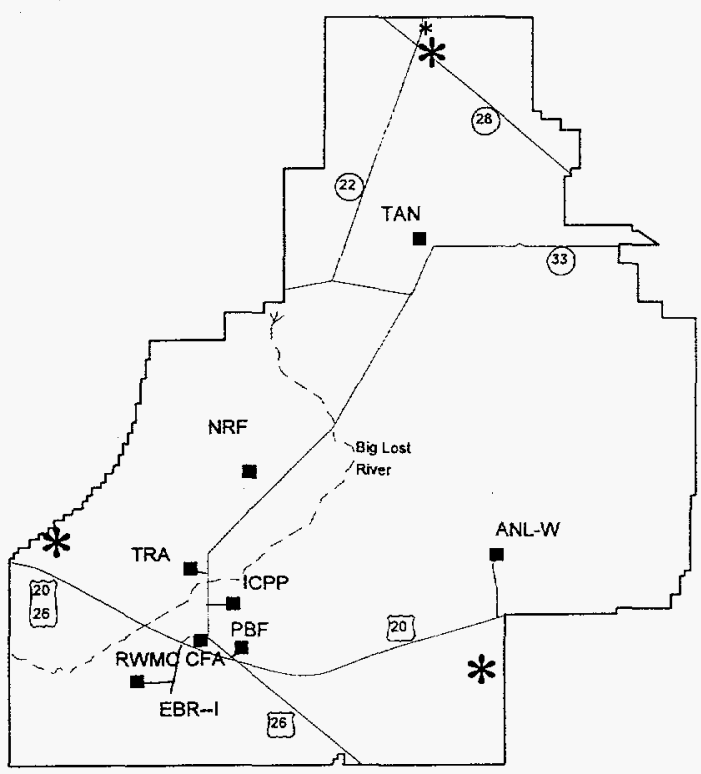

spotted knapweed (C. maculosa)

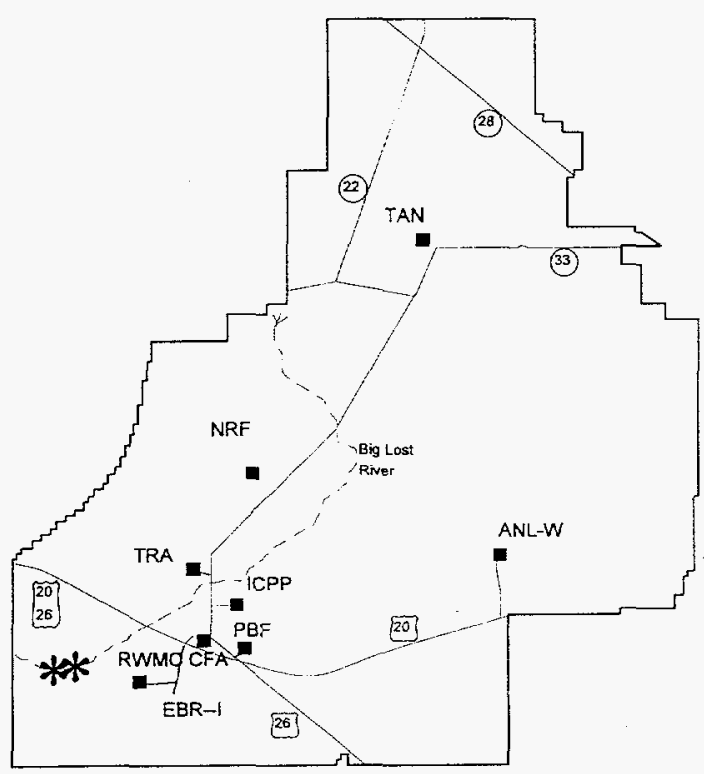

leafy spurge (E. esula)

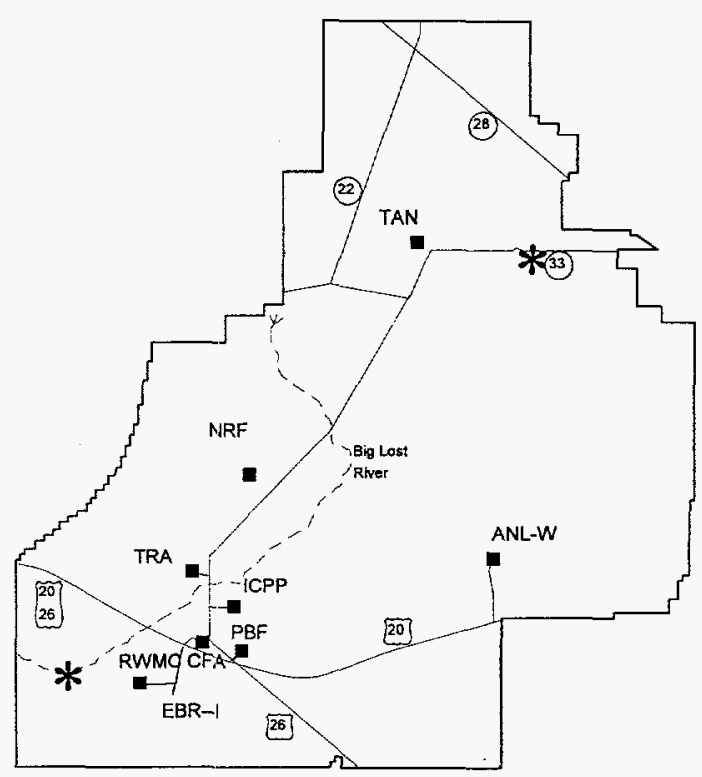

field bindweed (Convolvulus arvense)

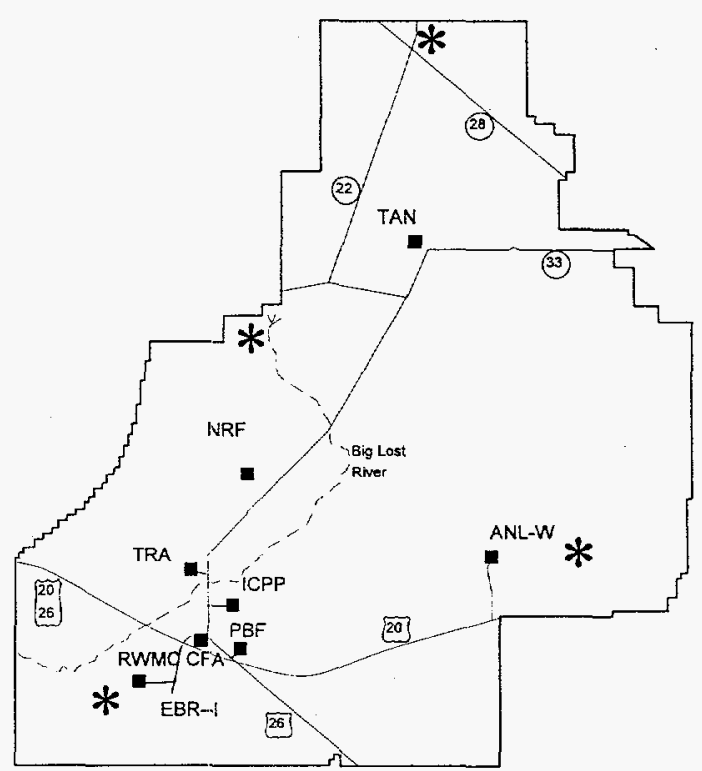

Canada thistle (Cirsium arvense)

Fig. 29. Locations (*) of spotted knapweed, field bindweed, leafy spurge, and Canada thistle found during surveys during 1996. 


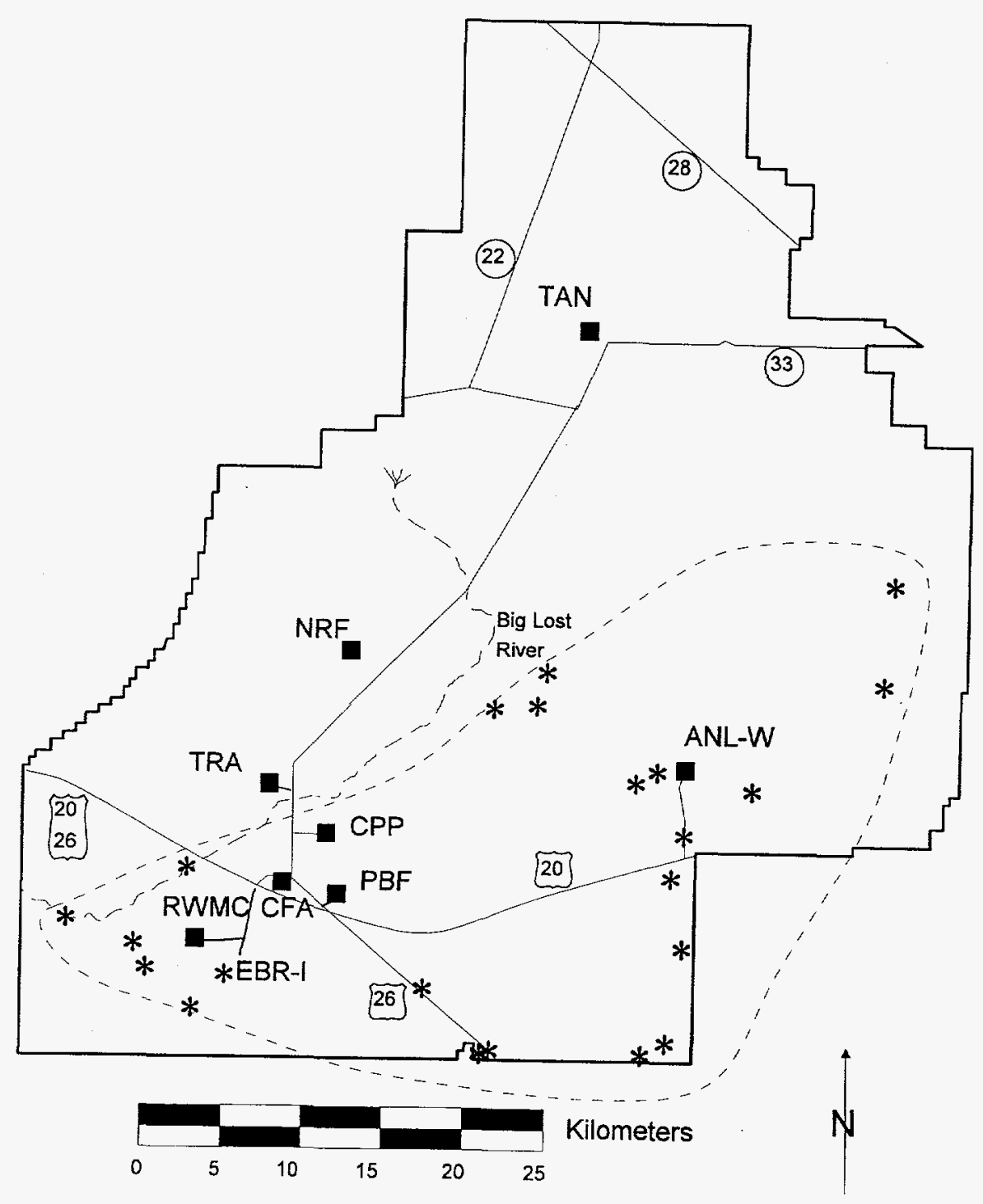

Fig. 30. Locations (*) of infestations of musk thistle found during 1996. Dashed line indicates probable extent of invasion on and near INEEL. 


\title{
HABITAT USE BY SUMMER POPULATIONS OF BATS IN SAGEBRUSH STEPPE
}

\author{
Shauna Haymond and Duke S. Rogers ${ }^{32}$
}

\begin{abstract}
Because of its abundance of caves and protection from recreational disturbance, the Idaho National Engineering and Environmental Laboratory (INEEL) provides ideal habitat for many of southeastern Idaho's bat species. Four species known from the INEEL are former $\mathrm{C} 2$ candidates for the threatened and endangered species list. Two of these, long-eared myotis (Myotis evotis) and Townsend's big-eared bat (Corynorhinus townsendii), are classified as species of special concern. Several studies have been conducted on winter bat populations on INEEL, but little is known about the summer bat residents. The purpose of this study was to determine summer bat use on the site. Twenty-four lava-tube caves were surveyed. All but two of the caves had evidence of use by bats. Of those caves, all were used as night roosts and six were used as day roosts. No maternity colonies were located on INEEL. Surveys with echolocation detectors indicated a significant amount of foraging occurred in juniper woodlands. Bats were also identified foraging over several of the INEEL sewage sites and waste ponds. One bat previously banded during a winter study was located.
\end{abstract}

Keywords: Corynorhinus townsendii, Myotis ciliolabrum, Myotis evotis, Myotis volans

\section{JUSTIFICATION}

Access to the Idaho National Engineering and Environmental Laboratory (INEEL) is strictly controlled. Consequently, wildlife populations have been protected from recreational disturbance. INEEL lands are characterized as sagebrush steppe vegetation with numerous lava-tube caves. These variables make INEEL lands highly suitable to bat populations. As unprotected bat habitat undergoes increasing degradation elsewhere, it becomes essential that research be conducted in areas of suitable habitat to provide responsible and scientifically-based management guidelines.

Fourteen species of bats occur in Idaho; seven of these are found on INEEL lands. Of these seven, four are former federal candidate (C2) species, and one is also a state species of special concern. Although several studies have been conducted on wintering bats of the INEEL and in particular on Townsend's big-eared bat (Corynorhinus [Plecotus] townsendii)(Wackenhut 1990, Keller et al. 1993, Bosworth 1994, Doering 1996), little is known about the basic biology for species that summer in the area (e.g. locations of significant roost sites, foraging habits, and movement patterns).

\section{Objective}

Our efforts concentrated on the four former federal candidate (C2) species of bat known to utilize INEEL lands: long-eared myotis (Myotis evotis), small-footed myotis (M. ciliolabrum), Townsend's big-eared bat (Corynorhinus townsendii)(a state species of special concern) and long-legged myotis ( $M$. volans). Roost sites used by other bat species were also recorded.

Objectives of the project were to determine:

- Summer bat use of lava-tube caves on the INEEL.

- Locations of day and night roosts on the INEEL, including lava-tube caves, basalt outcrops, buildings and bridges.

- Major foraging areas.

- Locations of maternity roosts on the INEEL.

- Summer locations of bats that winter in caves on the INEEL.

\footnotetext{
${ }^{32}$ Department of Zoology, Brigham Young University, Provo, UT 84602
} 


\section{PROJECT ACCOMPLISHMENTS}

- We surveyed 24 lava-tube caves on the INEEL for use by bats during the summer.

Summer bat use of lave-tube caves was determined by internal and external surveys conducted during day and night. Internal surveys assessed bat use based on presence of bats, presence of guano (bat droppings), presence of wrappers (remains of insects) and presence of urine and body stains. External surveys were conducted at night using exit counts (estimating the number of bats exiting the site) and echolocation analysis (for species identification).

- We surveyed 24 caves, 6 bridges and overpasses, and 56 buildings for evidence of day or night use by bats.

Day and night roosts were located by internal and external cave surveys, outcrop surveys, bridge and building surveys, and mist netting. Cave, outcrop, building, and bridge surveys assessed bat use based on odors, urine stains, guano, wrappers and presence of bats. Mist netting and echolocation analysis allowed us to identify species and gather life history information.

- Major foraging areas were identified by echolocation detection and mist netting.

A bat echolocation detector was used along transects in juniper and sagebrush dominated habitat, and along the Big Lost River, to identify foraging areas. Each transect was conducted one, three and five hours after sunset. Human-made waste ponds on the INEEL also were surveyed for bat use using a bat detector. Previous mist netting attempts at these ponds (Keller et al. 1993) yielded little success because of the large area covered by water. It was determined that bat detector equipment would provide more information on bat use of the ponds. Surveys at ponds were conducted as close to water as possible. Because access to some ponds was restricted by fences, these ponds were surveyed from beyond fence perimeters. Surveys were conducted from one hour after sunset until five hours after sunset. This is considered to be the optimal activity period for bats in the area (Bosworth 1996).

- We attempted to locate maternity roosts on the INEEL.

Attempts to locate maternity roosts were conducted during cave surveys, light tagging and mist netting.

- We used previously installed bands to evaluate summer locations of bats that winter in caves on the INEEL.

Because previous work conducted with bats on the INEEL included banding individuals, we recorded any recaptures as part of our surveys. Recaptures during the summer would provide information on movement patterns of banded individuals.

\section{IMPORTANT RESULTS}

Four species of bats were identified using INEEL lava-tube caves during the summer: Townsend's big-eared bat ( $C$. townsendii--day and night roosts), small-footed myotis ( $M$. ciliolabrum--day and night roosts), long-eared myotis ( $M$. evotis--night roost) and big brown bat (Eptesicus fuscus--night roost).

Of the 24 lava-tube caves examined on the INEEL, all but two were used day and/or night roosts (Table 22). Bats in day roosts were discovered roosting singly, each in a different cave. Eight dead bats also were discovered. Six of these were skeletons found in West Rattlesnake Cave; all of which were species of Myotis. One Townsend's big-eared bat was found in College Cave. A lactating small-footed myotis was captured at Moonshiner Cave. Based on the amount of 
Table 22. Types of summer bat roosts located in INEEL lava tube caves determined by day surveys, mist netting and by use of bat detector.

\begin{tabular}{|c|c|c|}
\hline Cave Name & Species & Type of Roost \\
\hline \multirow[t]{2}{*}{ College Cave } & Corynorhinus townsendii & Night \\
\hline & Myotis ciliolabrum & Night \\
\hline \multirow[t]{3}{*}{ Middle Butte Complex } & C. townsendii & Night \\
\hline & M. ciliolabrum & Day and Night \\
\hline & Eptesicus fuscus & Night \\
\hline EBRII Cave1 & Unknown & Night \\
\hline EBRII Cave2 & Unknown & Night \\
\hline EBRII Cave3 & C. townsendii & Day and Night \\
\hline \multirow[t]{2}{*}{ E. Rattlesnake } & C. townsendii & Night \\
\hline & M. ciliolabrum & Night \\
\hline \multirow[t]{2}{*}{ W. Rattlesnake } & C. townsendii & Night \\
\hline & M. ciliolabrum & Day and Night \\
\hline Flat Tire & C. townsendii & Day and Night \\
\hline \multirow[t]{2}{*}{ N. Tower--Earl } & C. townsendii & Night \\
\hline & M. ciliolabrum & Night \\
\hline JeepTrail & M. ciliolabrum & Night \\
\hline N. Tower--Wackenhut & Unknown & Night \\
\hline Pygmy Cave & C. townsendii & Night \\
\hline \multirow[t]{2}{*}{ Lek Cave } & M. ciliolabrum & Night \\
\hline & E. fuscus & Night \\
\hline E. Deer Cave & Unknown & Night \\
\hline \multirow[t]{2}{*}{ E. Boundary Cave } & C. townsendii & Night \\
\hline & M. ciliolabrum & Night \\
\hline \multirow[t]{3}{*}{ Moonshiner } & C. townsendii & Day and Night \\
\hline & M. ciliolabrum & Night \\
\hline & $M$. evotis & Night \\
\hline \multirow[t]{2}{*}{ Lost Cave } & C. townsendii & Night \\
\hline & M. ciliolabrum & Night \\
\hline Coyote Cave & C. townsendii & Night \\
\hline Obscenity Snake Pit & No signs of bat use & \\
\hline April Fools & No signs of bat use & \\
\hline E. Aviator & C. townsendii & Night \\
\hline W. Aviator & C. townsendii & Night \\
\hline Holy S. Cave & M. ciliolabrum & Night \\
\hline \multirow[t]{2}{*}{ Jensen's Cave } & C. townsendii & Day and Night \\
\hline & M. ciliolabrum & Night \\
\hline
\end{tabular}


wrappers found, Middle Butte Cave, Pygmy Cave and Lek Cave appear to have the most night roost use. All but two caves (Obscenity Snake Pit and April Fools Cave) had wrappers and guano present.

Six bridges and overpasses were surveyed (Table 22). Bridges were made of concrete or metal culverts. Night roosts of Townsend's big-eared bat, small-footed myotis, and long-eared myotis were located. Two small-footed myotis were observed night roosting at the Argonne West North bridge. Guano was observed at all the night roost bridges. Two bridges, the Argonne West South bridge and the Highway 20 underpass, did not serve as bat roosts.

External day surveys were conducted at 56 Central Facilities Area buildings and structures. Guano was found at six buildings (Table 24), suggesting use as night roosts by small-footed myotis and big brown bats.

Day searches of rock crevices and outcrops on East Butte located no day roosts and seven night roosts. Guano from long-eared myotis was found in the crevices. It is speculated that many more crevices are used as night roosts.
Bats appeared to be associated more with juniper woodlands for foraging than other vegetation types (Table 25). It also appeared that bats foraged within cave craters more than the surrounding sagebrush areas. This is likely because humidity levels in the craters is higher, resulting in greater insect densities.

The juniper dominated areas had several bats (small-footed myotis and Townsend's big-eared bats) foraging during each time interval. Two bats were detected (smallfooted myotis) in the sagebrush transect. The transect conducted along the Big Lost River detected one big brown bat.

Eight waste pond complexes on the INEEL were surveyed for use by bats (Table 26). Echolocation recordings were analyzed for species presence as well as feeding buzzes or passes. A "pass" indicated that one or more individuals was detected flying over or near water. A "feeding buzz" indicated that one or more individuals was hunting insects. Preliminary analyses of recordings indicated that big brown bats and small-footed myotis used these ponds as foraging areas. Both species foraged over sewage lagoons as well as industrial waste ponds. The Central Facilities Area sewage lagoons were the only

Table 23. Results of bat surveys of INEEL bridges.

\begin{tabular}{llll}
\hline Bridge Location & Bridge Material & Species & Roost Type \\
\hline Rest Stop & concrete & Corynorhinus townsendii & Night \\
& & Myotis ciliolabrum & Night \\
Highway 20 & concrete & No bat use & \\
Lincoln Blvd. near ICPP & metal culverts & M. ciliolabrum & Night \\
Lincoln Blvd. North & concrete & M. ciliolabrum & Night \\
& & $M$. evotis & Night \\
Argonne West North & concrete & M. ciliolabrum & Night \\
& & C. townsendii & Night \\
Argonne West South & concrete & No bat use & \\
\hline
\end{tabular}


Table 24. INEEL Central Facilities Area buildings used as bat roosts.

\begin{tabular}{lllc}
\hline Building Number & Building Material & Species & Roost Type \\
\hline CFA-690 & cinder block & Myotis ciliolabrum & Night \\
CFA-1608 & aluminum siding & Eptesicus fuscus & Night \\
CFA-696 & aluminum siding & M. ciliolabrum & Night \\
CFA-662 & cinder block and glass & M. ciliolabrum & Night \\
CFA-689 & glass and brick & E. fuscus & Night \\
CFA-698 & aluminum siding and stucco & $M$. ciliolabrum & Night \\
\hline
\end{tabular}

ponds where bat activity was not detected. These results are consistent with historical data (Keller et al. 1993). The ANL sewage lagoons had the highest bat activity based on the number of recordings made at the area. An unidentified bat was observed drinking from a sewage lagoon at ANL.

It is important to emphasize that calls of low frequency (i.e., from Townsend's big-eared bats) are easily overwhelmed by calls of higher frequency (i.e., small-footed myotis), especially when there are high levels of activity. Because it is also difficult to determine abundance from the number of calls detected, bat detectors were used as a preliminary tool to determine if there was any bat activity in an area.

No maternity roosts were located on the INEEL as a result of these survey efforts. Twenty-four lava-tube caves were surveyed. All but two of the surveyed caves have some type of bat use. Of the caves being utilized,

Table 25. Results of bat detector transects in juniper and sagebrush dominated areas and along the Big Lost River.

\begin{tabular}{lcc}
\hline Vegetation Type & Hours After Sunset & Species Detected (\#) \\
\hline Juniper & One & Myotis ciliolabrum (multiple) \\
& Three & M. ciliolabrum (multiple) \\
& Five & Corynorhinus townsendii (1) \\
Sagebrush & One & M. ciliolabrum (multiple) \\
& Three & M. ciliolabrum $(1)$ \\
Big Lost River & Five & None \\
& One & M. ciliolabrum (1) \\
& Three & Eptesicus fuscus $(1)$ \\
& Five & None \\
& & None
\end{tabular}


Table 26. Results of bat surveys of human-made ponds on the INEEL. A "pass" means one or more individuals were detected flying over or near water. A "feeding buzz" indicates that one or more individuals were hunting insects.

\begin{tabular}{|c|c|c|}
\hline Pond location & Species detected & Type of call detected \\
\hline $\begin{array}{l}\text { Test Area North (LOFT ponds [2]; TAN } \\
\text { pond) }\end{array}$ & $\begin{array}{l}\text { Eptesicus fuscus } \\
\text { Myotis ciliolabrum }\end{array}$ & $\begin{array}{l}\text { pass } \\
\text { pass, feeding buzz }\end{array}$ \\
\hline $\begin{array}{l}\text { Test Reactor Area (Sewage lagoons [2], } \\
\text { waste ponds [2]) }\end{array}$ & $\begin{array}{l}\text { E. fuscus } \\
\text { M. ciliolabrum }\end{array}$ & $\begin{array}{l}\text { pass } \\
\text { feeding buzz, pass }\end{array}$ \\
\hline $\begin{array}{l}\text { Idaho Chemical Processing Plant } \\
\text { (Sewage lagoons [4], industrial waste } \\
\text { ponds [2]) }\end{array}$ & $\begin{array}{l}\text { M. ciliolabrum } \\
\text { E. fuscus } \\
\text { Myotis spp. }\end{array}$ & $\begin{array}{l}\text { feeding buzz, pass } \\
\text { pass } \\
\text { pass }\end{array}$ \\
\hline $\begin{array}{l}\text { Central Facilities Area (Sewage lagoons } \\
\text { [2]) }\end{array}$ & No bats detected & \\
\hline $\begin{array}{l}\text { Agronne National Laboratory West } \\
\text { (Sewage lagoons [2]) }\end{array}$ & $\begin{array}{l}\text { E. fuscus } \\
\text { M. ciliolabrum } \\
\text { Myotis spp. }\end{array}$ & $\begin{array}{l}\text { feeding buzz, pass } \\
\text { feeding buzz, pass } \\
\text { pass }\end{array}$ \\
\hline RWMC (north pond) & $\begin{array}{l}\text { E. fuscus } \\
\text { M. ciliolabrum }\end{array}$ & $\begin{array}{l}\text { feeding buzz, pass } \\
\text { pass }\end{array}$ \\
\hline
\end{tabular}

all were used as night roosts and six were day roosts.

Cave temperatures ranged from $1.7^{\circ} \mathrm{C}$ to $23.9^{\circ} \mathrm{C}$. Average cave temperatures suggest that most of the caves on INEEL are too cold to serve as maternity roosts which typically require temperatures above $19^{\circ} \mathrm{C}$ (Clark et al. 1996, Pierson et al. 1991).

One banded Townsend's big-eared bat was located at Moonshiner cave. Although the band number was not readable, this bat was likely banded in West Rattlesnake Cave during an earlier bat study on the INEEL in 1988. No other banded bats were located. Craters of the Moon National Park (about 45 $\mathrm{km}$ [28 miles] from INEEL) has three maternity colonies in which no banded bats have been discovered.

\section{PRODUCTS}

Results of the study will be compiled into a management protocol for former $\mathrm{C} 2$ species in Idaho and will serve as baseline data for use in the design of future studies.

Manuscripts will be submitted for peer review to one or more of the following technical journals: Journal of Mammalogy, Journal of Wildlife Management, Great Basin Naturalist and Southwestern Naturalist.

\section{LITERATURE CITED}

Bosworth, W. R., III. 1996. Methods for monitoring bat population trends at lava-tube caves on the Idaho National Engineering Laboratory. Environmental Science and Research Foundation, Idaho 
Falls, ID ESRF-013. 17 pp.

Bosworth, W. R., III. 1994. Characteristics of winter activity in Plecotus townsendii in southeastern Idaho. M.S. Thesis, Idaho State University, Pocatello. 74 pp.

Clark, B. K., B. S. Clark, D. J. Leslie, Jr., and M. S. Gregory. 1996. Characteristics of caves used by the endangered Ozark big-eared bat. Wildlife Society Bulletin 24:8-14.

Doering, R. W. 1996. Thermal implications of roost site selection in hibernating Plecotus townsendii. M.S. Thesis, Idaho State University, Pocatello. 109 pp.

Keller, B. L., W. R. Bosworth, and R. W. Doering. 1993. Bat habitat research: final technical report. U. S. Department of
Energy, Idaho Field Office, Idaho Falls, ID. $20 \mathrm{pp}$.

Pierson, E. D., W. E. Rainey, and D. M. Koontz. 1991. Bats and mines: experimental mitigation for Townsend's big-eared bat at the McLaughlin Mine in California. Pages 31- 42 in Proceedings V: Issues and Technology in the Management of Impacted Wildlife. Thorne Ecological Institute, Boulder, $\mathrm{CO}$.

Wackenhut, M. C. 1990. Bat species overwintering in lava-tube caves in Lincoln, Gooding, Blaine, Bingham and Butte Counties, Idaho with special reference to annual return of banded Plecotus townsendii. M.S. Thesis, Idaho State University, Pocatello. 64 pp. 


\title{
TRACE ELEMENTS AND ORGANICS IN SURFACE SOILS AT THE SUBSURFACE DISPOSAL AREA
}

\author{
Ron Brooks and Randall C. Morris ${ }^{33}$
}

\begin{abstract}
Samples of soil excavated by small mammals and adjacent, nonexcavated soils were collected from the Subsurface Disposal Area (SDA) and analyzed for trace elements and organic pesticides. Over all transects, $\mathrm{Hg}$ was found at higher concentrations in nonexcavated soils than in excavated soils, possibly from industrial operations at $\mathrm{SDA}$. Concentrations of $\mathrm{Hg}, \mathrm{Si}, \mathrm{Al}, \mathrm{Pb}, \mathrm{Mg}$, Ti, and $\mathrm{Y}$ were significantly higher in surface soil samples than in excavated soils in at least one of the four sample areas. Concentrations of $\mathrm{Cu}, \mathrm{Y}, \mathrm{Ba}, \mathrm{Fe}, \mathrm{Pb}, \mathrm{Ni}, \mathrm{K}, \mathrm{V}$, and Aldrin were significantly higher in excavated soils than in surface soils in at least one of the four sample areas. The organic pesticide Aldrin was found in soils excavated by small mammals at the SDA in concentrations up to $18 \mu \mathrm{g} \mathrm{kg}^{-1}$. It was also found in nonexcavated soils in concentrations up to $5.2 \mu \mathrm{g} \mathrm{kg}^{-1}$. To explain the presence of Aldrin in these samples, further samples were collected from the Big Lost River spreading areas south of the SDA. These samples were analyzed in 1995. No Spreading Area samples contained Aldrin above detection limits. Although no records or institutional memory of Aldrin use exists, this implies that the Aldrin detected in earlier sampling was derived from either INEEL or Rocky Flats waste stored at the SDA.
\end{abstract}

Keywords: Aldrin, soils, Subsurface Disposal Area, trace elements

\section{JUSTIFICATION}

Since 1952 , radioactively contaminated waste has been disposed at the INEEL Subsurface Disposal Area (SDA). Due to deterioration of waste containers, contamination has occurred in SDA subsurface soils. Other hazardous waste components, including trace elements and organics, are buried with the radioactive waste at the SDA.

Trace elements and organics have increasing political visibility relative to radioactive contaminants and, similar to radioactive contaminants, they have potential for dispersal through biotic pathways. Thus, it is important to understand and monitor the ways in which these contaminants might be transported in the environment. One potentially important means of transport is small mammals bringing contaminants to the surface in soil excavated by their burrowing. This contaminated soil is then available for dispersal by wind.

Radionuclide transport by biota was well investigated at the SDA. Arthur and Markham (1982) estimated that $270 \mathrm{kBq} \mathrm{y}^{-1}$ of radioactivity was exported from the SDA by coyotes due to their consumption and subsequent elimination of contaminated small mammals (Arthur and Janke 1986).

Approximately $49 \%$ of deer mice (Peromyscus maniculatus) and $20 \%$ of kangaroo rats (Dipodymus ordii) inhabiting the SDA encounter areas of buried radioactive waste or contaminated soil (Arthur et al. 1987). Burrowing by these small mammals transports transuranics to the surface (Arthur and Markham 1983). Arthur et al. (1987) estimated that $844 \mathrm{kBq} \mathrm{y}^{-1}$ of mixed radioactivity was deposited on the surface of the SDA by burrowing deer mice and dispersing deer mice transported $310 \mathrm{kBq} \mathrm{y^{-1 }}$ from the SDA.

A relative wealth of information is available concerning radionuclide transport by biota at the SDA. However, no published studies report similar investigations of trace elements and organics. Therefore, our objectives were to determine whether concentrations of trace elements and organic pesticides are greater in SDA surface soils than background areas and to determine whether small mammal burrowing has brought trace elements and organic pesticides to the soil surface. Samples of soil excavated

${ }^{33}$ Environmental Science and Research Foundation, P.O. Box 51838, Idaho Falls, ID 83405-1838 
by small mammals and adjacent, nonexcavated soils were collected from the SDA and analyzed for trace elements and organic pesticides. Over all transects, $\mathrm{Hg}$ was found at higher concentrations in non-excavated soils than in excavated soils, possibly as a result of industrial operations (construction and vehicle exhaust) at the SDA. The organic pesticide Aldrin was found in small mammal excavated soils in concentrations up to $18 \mu \mathrm{g} \mathrm{g}^{-1}$. It was also found in nonexcavated soils in concentrations up to $5.2 \mu \mathrm{g} \mathrm{g}^{-1}$. As a result, the objectives were expanded in 1994 to include determining if Aldrin entered the SDA in cover soil that was contaminated by upstream agriculture. To address this, 12 samples from the Big Lost River Spreading Areas were taken and sent for analysis in 1995. These samples were taken from undisturbed areas, inactive borrow locations, and active borrow locations in the Spreading Areas.

\section{Objectives}

To meet the overall objectives of the study, the following objectives were established for 1996:

- Compile and analyze all data from original samples and the additional samples collected from the Big Lost River Spreading Areas in 1995.

\section{PROJECT ACCOMPLISHMENTS}

The original data set consisted of results of samples taken from waste areas $\mathrm{A}$ and $\mathrm{C}$, a control site, and the Big Lost River Spreading Areas. During 1996, the data set was modified to include results of samples taken from waste areas B and D.

A two-tailed, paired t-test (SPSS for Windows) was used to re-analyze the data set to detect significant differences between surface and excavated soils from the four sampling areas (A-D).

A draft manuscript was produced and submitted for review. Revisions are currently being made.

\section{IMPORTANT RESULTS}

Spreading Area samples did not contain Aldrin above detection limits. Aldrin was measured above detection limits in all four SDA sampling areas (A-D). For the four sampling areas: Area A contained mainly waste from the INEEL; area C contained waste primarily from Rocky Flats, and areas $\mathrm{B}$ and $\mathrm{D}$ contained waste from both the INEEL and Rocky Flats. Although no records or institutional memory of Aldrin use exists, this implies that the Aldrin detected in earlier sampling was derived from either or both INEEL or Rocky Flats waste stored at the SDA. However, further sampling is required to verify the presence of Aldrin in the SDA soils.

Mercury, $\mathrm{Si}, \mathrm{Al}, \mathrm{Pb}, \mathrm{Mg}, \mathrm{Ti}$, and $\mathrm{Y}$ were significantly higher in surface soil samples from at least one of the four sampling areas. Copper, $\mathrm{Y}, \mathrm{Ba}, \mathrm{Fe}, \mathrm{Pb}, \mathrm{Ni}, \mathrm{K}, \mathrm{V}$, and Aldrin were significantly higher in small mammal excavated soils in at least one of the four sample area. These results suggest that small mammals are indeed bringing trace elements and organics to the surface, although not in significant amounts. As Mercury is a common industrial pollutant, its higher concentrations in surface soils may be due to industrial operations at the SDA such as construction activities or automobile traffic.

\section{PRODUCTS}

A draft manulscript was produced in 1996. Review of the manuscript suggested there be additional data analysis. Another draft is currently being prepared.

\section{LITERATURE CITED}

Arthur, W. J. and D. H. Janke. 1986.

Radionuclide concentrations in tissues of 
wildlife occurring at a solid radioactive waste disposal area. Northwest Science 60:154-159.

Arthur, W. J. and O. D. Markham. 1982.

Ecological vectors of radionuclide transport at a solid radioactive waste disposal facility in southeastern Idaho. Pages 574-580 in M. A. Faraday, ed., Proceedings of the International Conference on Radioactive Waste Management. Winnipeg, Manitoba.

Arthur, W. J., O. D. Markham, C. R. Groves, and B. L. Keller. 1987. Radionuclide export by deer mice at a solid radioactive waste disposal area in southeastern Idaho. Health Physics 52:45-53.

Arthur, W. J. and O. D. Markham. 1983.

Small mammal soil burrowing as a radionuclide transport vector at a radioactive waste disposal area in southeastern Idaho. Journal of Environmental Quality 12:117-122.

Rope, S. K., W. J. Arthur, T. H. Craig, and E. H. Craig. 1988. Nutrient and trace elements in soil and desert vegetation of southern Idaho. Environmental Monitoring and Assessment 10:1-24. 


\title{
UPTAKE PARAMETERS OF CONTAMINANTS AND SPECIES IMPORTANT TO INEEL ECOLOGICAL RISK ASSESSMEN'T
}

\author{
Randall C. Morris ${ }^{34}$
}

\begin{abstract}
Currently, the Idaho National Engineering and Environmental Laboratory (INEEL) is conducting Ecological Risk Assessments for the Waste Area Groups and planning the Site-wide Ecological Risk Assessment. Some contaminants of concern have failed to pass the screening criteria (VanHorn et al. 1995) and require further analysis (Personal communication, R. VanHorn, LMITCO). However, little information is available on uptake coefficients for many of these contaminants in soils and organisms characteristic of the INEEL. Thus, risk assessors may be required to use apparently conservative estimates for these parameters and the resulting assessments may not accurately represent the true risk from the contaminants. This experiment will provide site-specific uptake data for risk assessments, reducing the dependence on values estimated from other sites and other species. The specific objectives of the experiment are to determine the equilibrium plant-soil concentration ratio for two contaminants important for INEEL risk assessment in the parts of several common plant species existing on the INEEL, and to determine the deer mouse (Peromyscus maniculatus)-soil concentration ratio for those contaminants. In 1996, the experimental apparatus was constructed. Funding delays and problems obtaining the necessary equipment delayed transplanting sagebrush (Artemisia tridentata) and rabbitbrush (Chrysothamnus viscidiflorus) until summer 1996. The transplants were unsuccessful and will be repeated in early spring 1997.
\end{abstract}

Keywords: Ecological risk assessment, plant uptake, rabbitbrush, sagebrush, soil.

\section{JUSTIFICATION}

Accurate risk assessments require highquality data. In the absence of data, risk assessors must apply a high degree of conservatism to their calculations to ensure acceptably low human and ecological risk. This frequently means that cleanup criteria are set at unreasonably low levels, increasing the cost of cleanup. Alternatively, even using what seem to be conservative estimates for parameters, lack of data my cause risk assessors to significantly underestimate risk to humans or non-human organisms.

The best data come from experiments conducted under site-specific field conditions, using the particular chemicals of interest and local species. Variation from these conditions degrades the utility of the data and requires the inclusion of conservative safety factors in all calculations.

Currently, the Idaho National Engineering and Environmental Laboratory (INEEL) is conducting Ecological Risk Assessments for the Waste Area Groups and planning the Sitewide Ecological Risk Assessment. Some contaminants of concern have failed to pass the screening criteria (VanHorn et al. 1995) and require further analysis (Personal communication, R. VanHorn, LMITCO). However, little information is available on uptake coefficients for many of these contaminants in soils and organisms characteristic of the INEEL. Thus, risk assessors may be required to use apparently conservative estimates for these parameters and the resulting assessments may significantly over or underestimate the true risk from the contaminants.

This experiment is designed to provide site-specific data for risk assessments, reducing the dependence on values estimated from other sites and other species. This will benefit DOE-ID by increasing the accuracy of ecological risk assessments and, potentially, reducing the cost of remediation.

The basic methodology of the experiment is straightforward: plants are being grown in soil with known contaminant concentration and plant parts will be periodically analyzed for their contaminant concentration. The plant-soil concentration ratio will be

${ }^{34}$ Environmental Science and Research Foundation, P.O. Box 51838, Idaho Falls, ID 83405-1838. 
calculated from these data. Deer mice will be induced to live in the contaminated soil and eat the contaminated vegetation. Their tissues will be analyzed to determine the deer mousesoil concentration ratio. The experiment is replicated three times to provide the necessary statistical power. Environmental contamination is avoided by using nonhazardous chemicals and by designing the experimental apparatus to isolate the chemicals from the environment.

The specific objectives of the experiment are to:

- Determine the equilibrium plant-soil concentration ratio for $\mathrm{Cs}$ and $\mathrm{Sr}$ in the parts of several plant species existing on the INEEL.

We will use non-radioactive $\mathrm{CsCl}$ and $\mathrm{SrCl}$ for this experiment. Both of these are nonhazardous and will not result in contamination of the environment or generation of radioactive/hazardous wastes. The $\mathrm{Cs}$ and $\mathrm{Sr}$ will, however, be readily available for plant uptake and will be easily detected.

The plant species of interest include big sagebrush (Artemisia tridentata), green rabbitbrush (Chrysothamnus viscidiflorus), bluebunch wheatgrass (Pseudoroegneria spicata), thick-spiked wheatgrass (Elymus lanceolatus), Rocky Mountain penstemon (Penstemon strictus), and Lewis' flax (Linum perenne). The plant parts of interest include stems, leaves, and seedheads when available.

- Determine the deer mouse (Peromyscus maniculatus)-soil concentration ratio for the contaminants of interest.

\section{PROJECT ACCOMPLISHMENTS}

- The experimental apparatus was constructed.

Three 2.7-m (9-ft.) diameter stock tanks were buried in the ground at the experimental field station such that $25 \mathrm{~cm}$ (10 in.) protruded above the surface (Fig. 31). A 2.4$\mathrm{m}$ (8-ft.) tank was placed inside each of the original tanks on wooden supports. The space between the tanks was filled with clean soil, leaving a void under the inside tank. The inner tank was filled with clean soil and compacted to approximate the bulk density of undisturbed soil. The disturbed area surrounding the tanks was reseeded with a native plant mixture.

- Non-radioactive $\mathrm{CsCl}$ and $\mathrm{SrCl}$ were purchased for spiking the tanks.

- The tanks were seeded and shrubs were transplanted.

The same native plant mixture used to reseed the area surrounding the tanks was used to seed the inside of the tanks. In addition, transplants of sagebrush and rabbitbrush were attempted into the tanks. Unfortunately, because of delays in funding and obtaining necessary materials for constructing the tanks, the transplantations could not occur until mid-summer. As a result, the transplants failed. We will attempt again in early spring 1997.

\section{IMPORTANT RESULTS AND PRODUCTS}

This experiment is in its infancy and no results or products have been obtained.

\section{LITERATURE CITED}

VanHorn, R. L., N. L. Hampton, and R. C. Morris, Principle Investigators. 1995. Guidance manual for conducting screening level ecological risk assessments at the INEL. INEL-95/0190. Lockheed Idaho Technologies Company, Idaho Falls, ID. $511 \mathrm{pp}$. 


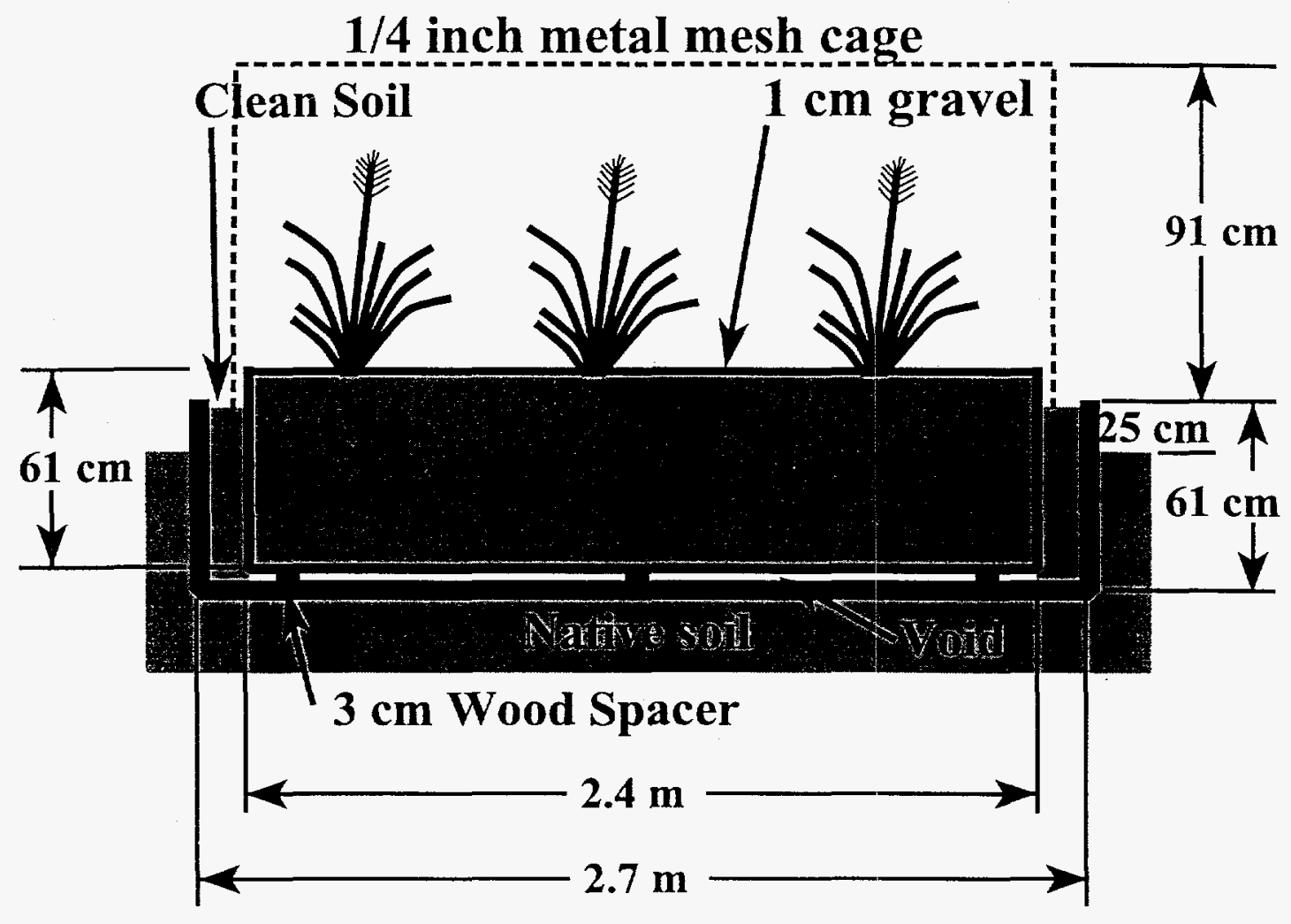

Fig. 31. A diagram of the experimental apparatus to determine the plant-soil concentration ratios for contaminants important to INEEL risk assessments. 


\title{
APPENDIX A \\ PUBLICATIONS BY FOUNDATION RESEARCHERS DURING 1996
}

\author{
Technical Publications
}

Anderson, J. E., K. T. Ruppel, J. M. Glennon, K. E. Holte, and R. C. Rope. 1996. Plant communities, ethnoecology, and flora of the Idaho National Engineering Laboratory. ESRF-005, Environmental Science and Research Foundation, Idaho Falls, Idaho. 111 pp.

Anderson, J. E. In Press. An ecological engineering approach for keeping water from reaching interred wastes in arid or semiarid regions. Accepted for publication in the Proceedings, 1997 International Containment Technology Conference and Exhibition.

Belthoff, J. R., L. R. Powers, T. D. Reynolds. In revision. Breeding birds at the Idaho National Engineering and Environmental Laboratory, 1985 - 1991. Great Basin Naturalist.

Blom, P. E., D. A. Schoep, and W. H. Clark. In revision. Observations of cicada nymphs, Okanagana annulata Davis (Homoptera: Cicadidae) and the harvester ant Pogonomyrmex salinus Olsen (Hymenoptera, Formicidae) in southeastern Idaho. Great Basin Naturalist.

Bromenshenk, J. J., J. L. Gudatis, and R. C. Cronn. Submitted. Heavy metal uptake in honey bees. Environmental Monitoring and Assessment.

Bromenshenk, J. J., R. C. Cronn, and J. J. Nugent. 1996. Monitoring fluoride with honey bees in the upper Snake River Plain of Idaho. Journal of Environmental Quality 25: 868-877.

Bromenshenk, J. J., R. C. Cronn, J. J. Nugent, J. L. Gudatis, and R. L. McGraw. Submitted. Dispersal of inorganic contaminants in the upper Snake River Plain of Idaho. Apidologie.

Bromenshenk, J. J., J. L. Gudatis, and R. C. Cronn. In press. Post-closure assessments of industrial complexes with honey bees. Environmental Contamination and Toxicology.

Brooks, R. and R. C. Morris. Draft. Trace elements and organics in surface soils at the subsurface disposal area.

Christian, T. J. 1996. Analysis of polychlorinated biphenyls in honey bees. M.S. Thesis. The University of Montana, Missoula. $60 \mathrm{pp}$.

Cieminski, K. L. Submitted. Mule deer and pronghorn use of wastewater ponds in a cold desert. Great Basin Naturalist.

Cieminski, K. L., and L. D. Flake. In press. Bird communities at wastewater ponds in southeastern Idaho. Proceedings of the 23rd Annual Conference on Ecosystem Restoration and Creation, Tampa, FL.

Clark, W. H., and P. E. Blom. Draft. Bibliography of the harvester ant genus Pogonomyrmex.

Clark, W. H., P. E. Blom, and P. J. Johnson. In revision. Gonasida elata LeConte associated with Pogonomyrmex salinus Olsen nest soils in southeastern Idaho (Coleoptera, Tenebrionidae, Asidinae; Hymenoptera, Formicidae, Myrmicinae). Proceedings of the Entomological Society of Washington.

Cooper, S. L. 1996. Geographic distribution of the Desert Night Snake (Hypsiglena torquata). Herpetological Review. 27(4):213.

Cooper, S. L. In Press. Idaho Species Account: Great Basin Spadefoot (Spea intermontana). Idaho Herpetological Society Newsletter.

Cronn, R. C., and J. J. Bromenshenk. In press. Radionuclide accumulation in honey bees at the Idaho National Engineering Laboratory. Journal of Environmental Quality. 
Flake, L. D. and K. L. Cieminski. In press. Waterfowl use of wastewater ponds on the Idaho National Engineering Laboratory. Proceedings of the 23rd Annual Conference on Ecosystem Restoration and Creation, Tampa, FL.

Ibrahim, S. A. In review. Distribution of Plutonium among Soil Phases near a Subsurface Disposal Area in Southeastern Idaho, USA. For submission to J. Radioanalytical and Nuclear Chemistry.

Laundré, J. W. Submitted. Effect of ground squirrel burrows on plant productivity in a cool desert environment. Journal of Range Management.

Laundré, J. W. Submitted. The relationship between carbon isotope ratios and sagebrush productivity. Oecologia.

Pearson, L. C. In review. Lichens as bioindicators of air quality at the Idaho National Engineering Laboratory. Great Basin Naturalist.

Pearson, L. C. In review. Environmentally friendly microchemical methods for biomonitoring air quality with lichens. Journal of Applied Ecology.

Pearson, L. C. Ready for Submission. Air pollution damage to cell membranes in lichens IV. Lichens of arid regions. Northwest Science.

Pearson, L. C. In review. Biomonitoring air quality with lichens using electrolyte leakage and energy dispersive spectroscopy. Bryologist.

Peek, J. and D. Beaver. In review. Review of supplemental feeding of big game in Western North America and Central Europe.

Rasmuson, K. E. 1996. Population and individual responses of Bromus tectorum to environmental stresses: a study of factors that may limit its distribution in cold-desert habitats. Ph.D. Dissertation, Idaho State University, Pocatello.

Reynolds, T. D., and T. D. Ratzlaff. Draft. Surface water penetration at the subsurface disposal area.

Smith, S. D., R. K. Monson, and J. E. Anderson. In press. Physiological ecology of North American Desert Plants. Springer-Verlag, Berlin. 286 pp.

Warren, R. W. Draft. Radionuclide cycling in plastic lined evaporation ponds and effects on radionuclide levels in and radiation doses to waterfowl and waterfowl hunters.

\section{Popular Articles}

Hansen, R. W. In review. Hawks of Idaho's high desert. Idaho Wildlife.

Hansen, R. W. and L. D. Flake. 1996. Prairie biologists in the desert. South Dakota

Conservation Digest. Pp. 12-13, 15. 


\section{APPENDIX B}

\section{TECHNICAL PRESENTATIONS DURING 1996}

Cieminski, K. L. and L. D. Flake. 1996, May. Bird communities at wastewater ponds in southeastern Idaho. 23rd Annual Conference on Ecosystem Restoration and Creation, Tampa, FL.

Cooper, S. L. and C. R. Peterson. 1996. Modeling the location of snake dens on the Idaho National Engineering Laboratory. Platform Presentation, American Fisheries Society Meetings. March 1, 1996, Logan, UT.

Cooper, S. L. and C. R. Peterson. 1996. Modeling the location of snake dens. Platform Presentation, Idaho Herpetological Society Meetings. November 9, Boise, ID.

Dobrowolski, J. P., and E. K. Duffin. 1996. Soil subsidence and snowmelt erosion on waste disposal sites. Faculty/graduate student seminar at Utah State University, Logan, UT.

Eshelman, B.D., and C. S. Sonnemann. 1996, June. Heavy metals in small mammal habitats and populations at the Idaho National Engineering Laboratory. Annual meeting of the American Society of Mammalogists, Grand Forks, ND.

Eshelman, B. D. 1996, February. The ups and downs of nutritional ecology. Invited Seminar, Department of Biological Sciences, University of Wisconsin-Whitewater, WI.

Flake, L. D. 1996, October. Wildlife research in a high desert--the INEL. Open seminar for faculty and students at South Dakota State University.

Flake, L. D. and K. L. Cieminski. 1996, May. Waterfowl use of wastewater ponds at the Idaho National Engineering Laboratory. 23rd Annual Conference on Ecosystem Restoration and Creation, Tampa, FL.

Flake, L. D. 1996, January. Raptors of the intermountain and prairie regions. Presented at the South Dakota Agricultural Heritage Museum, Brookings.

Flake, L. D. 1996, October. Bird studies in a desert shrub ecosystem, Idaho. Banquet speaker for South Dakota Ornithologist Union annual meeting. Brookings.

Heady, L. T., K. I. Gabler, and J. W. Laundré. 1996. Habitat and behavior assessment of an endemic rabbit species (Brachylagus idahoensis) in southeastern Idaho. Society for Conservation Biology and Ecological Society of America Joint Annual Meetings, Providence, RI.

Rasmuson, K. E. and J. E. Anderson. 1996. Root growth and water relations of Bromus tectorum in response to drying soil surfaces. Annual Meeting, Ecological Society of America, Providence, RI.

Roush, D. 1996, November. DOE's National Environmental Research Parks. North American Association for Environmental Education Annual Conference, Burlingame, CA.

Roush, D. Communicating about the Idaho National Engineering Laboratory's Environment. 1996, April. Ecopsychology: The Interconnectedness of Humans and the Environment, College of Social Sciences and Public Affairs, Boise State University, Boise, ID.

Sonnemann, C. S., and B.D. Eshelman. 1996, June. Avoidance of lead contaminated food sources by Peromyscus maniculatus. Annual meeting of the American Society of Mammalogists, Grand Forks, ND. 


\section{KEYWORD INDEX}

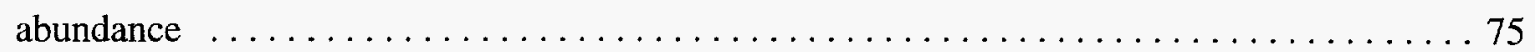

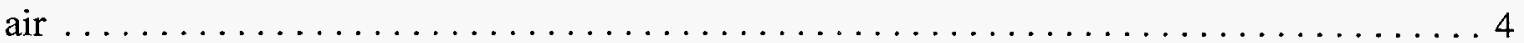

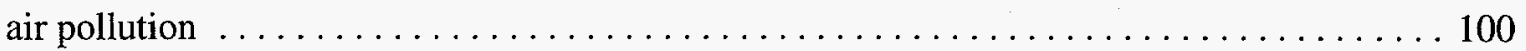

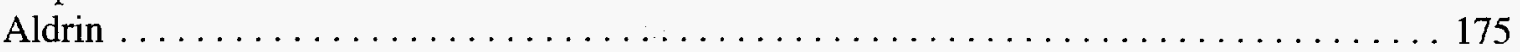

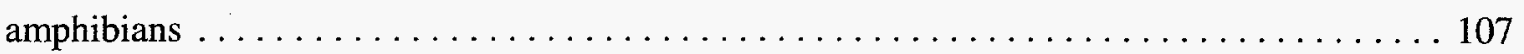

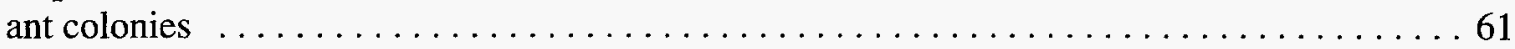

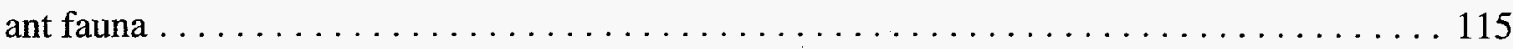

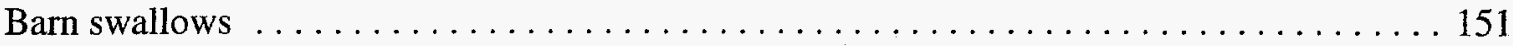

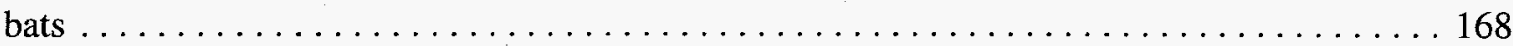

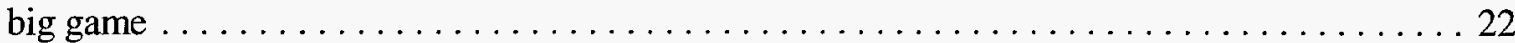

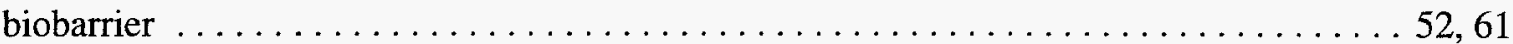

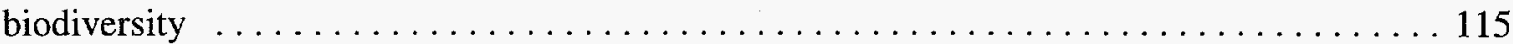

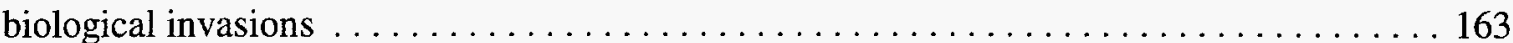

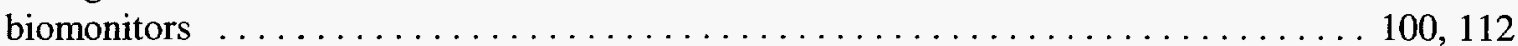

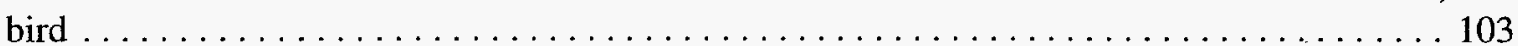

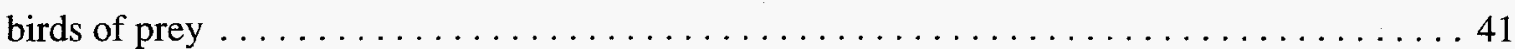

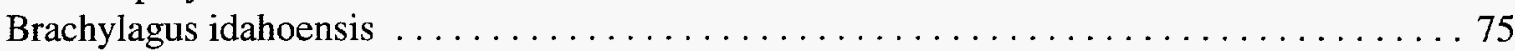

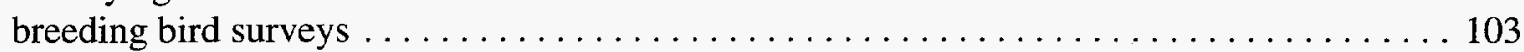

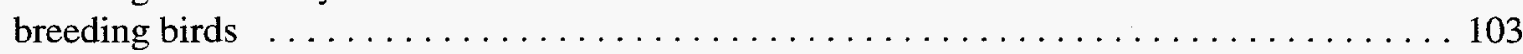

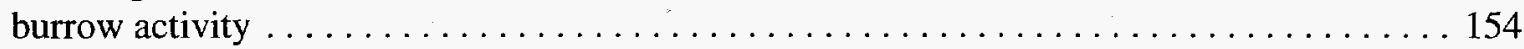

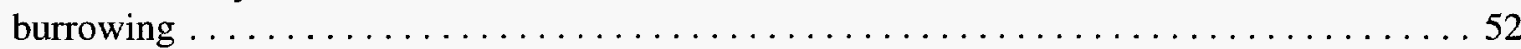

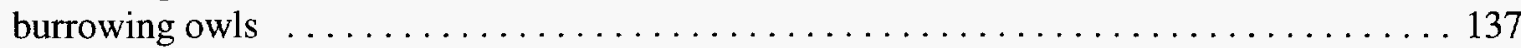

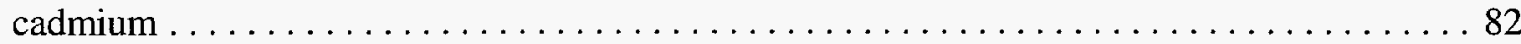

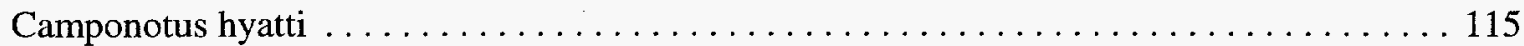

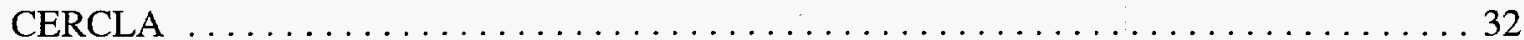

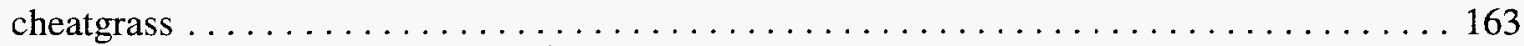

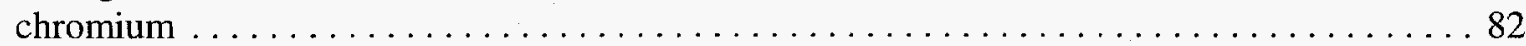

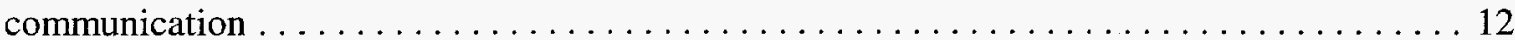

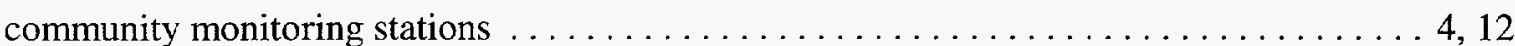

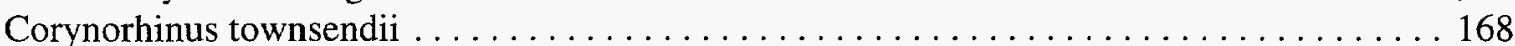

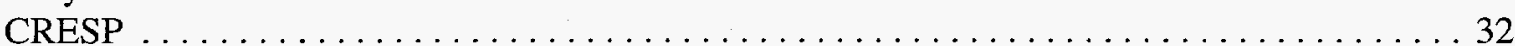

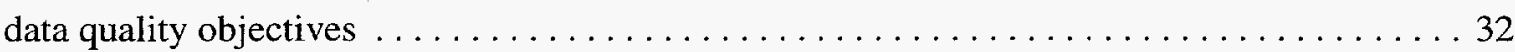

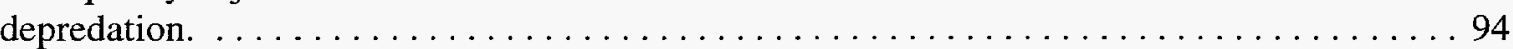

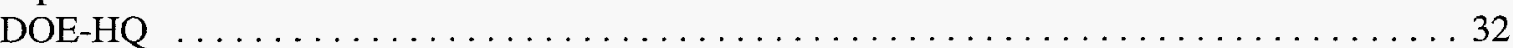

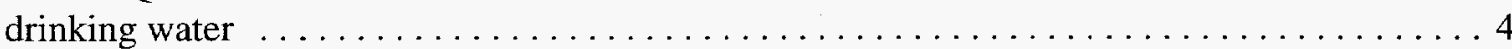

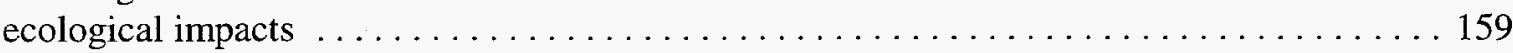

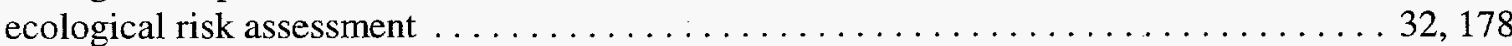

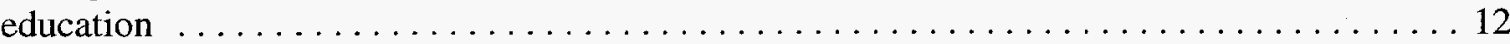

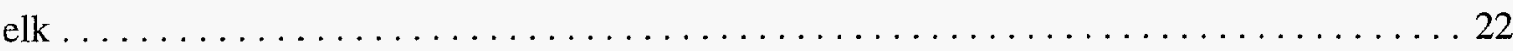

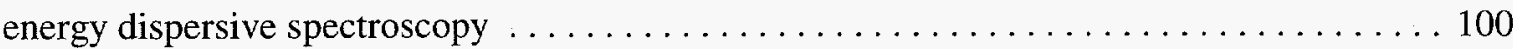

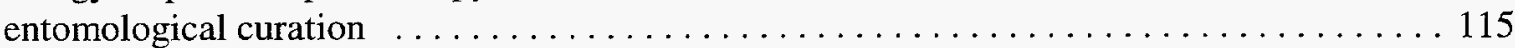

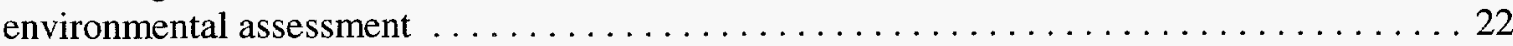

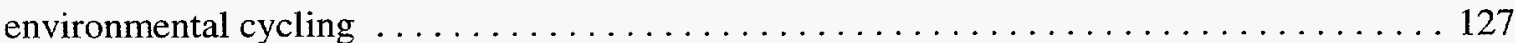

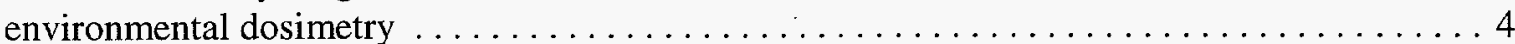

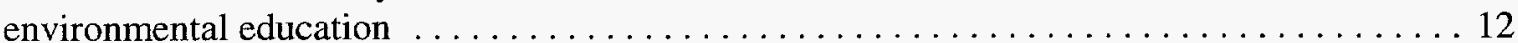




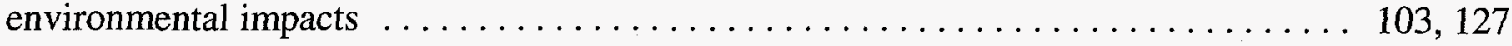

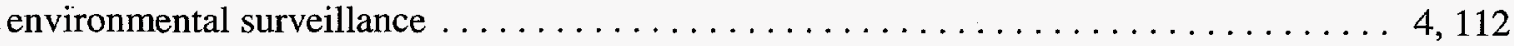

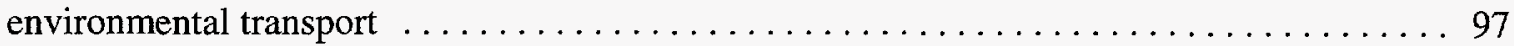

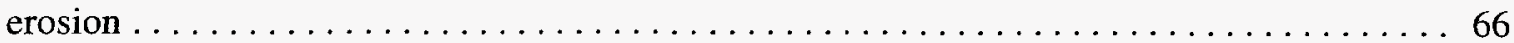

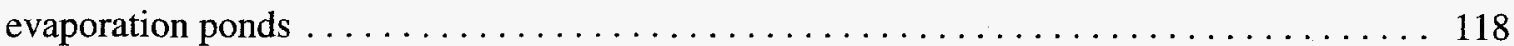

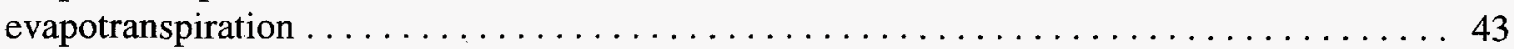

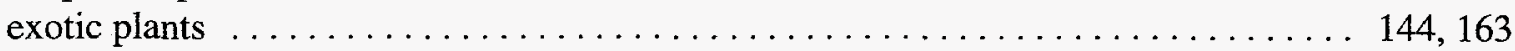

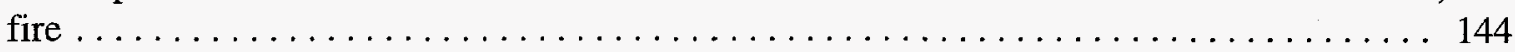

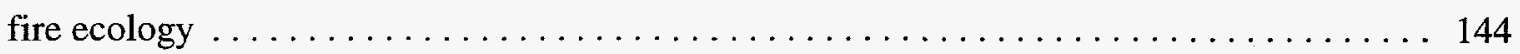

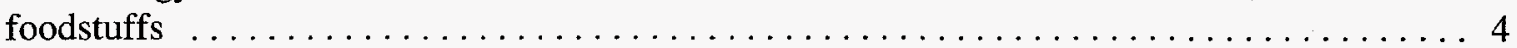

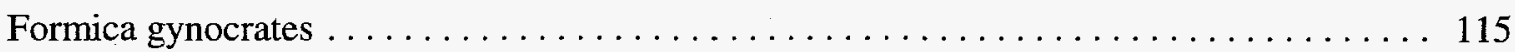

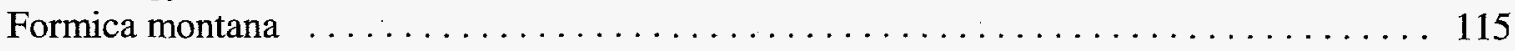

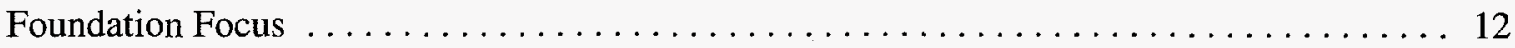

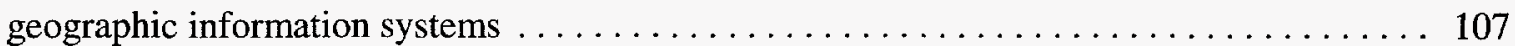

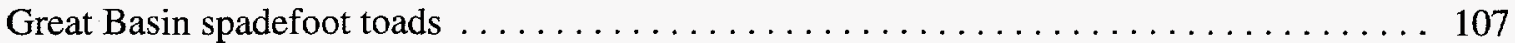

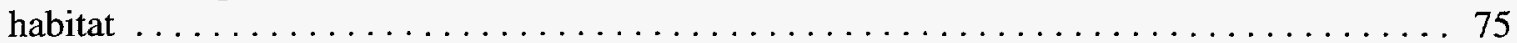

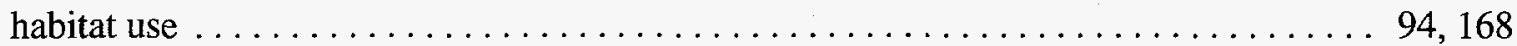

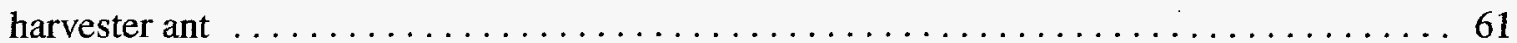

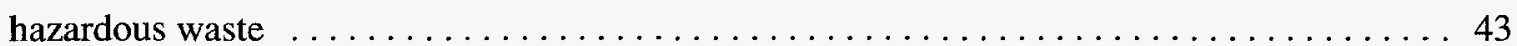

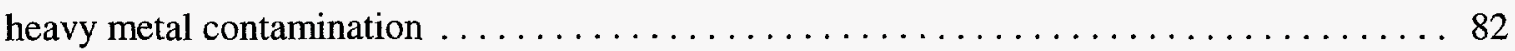

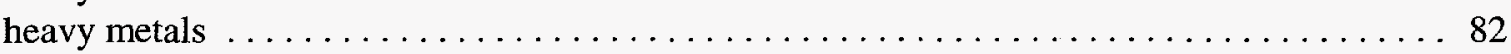

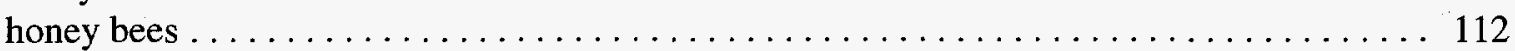

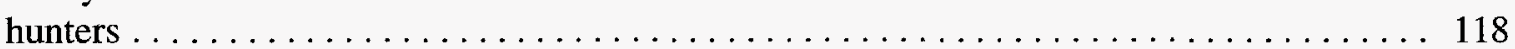

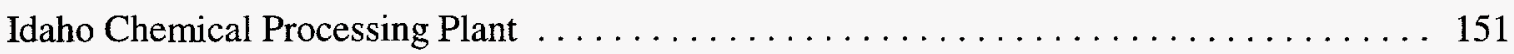

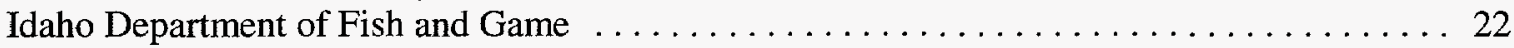

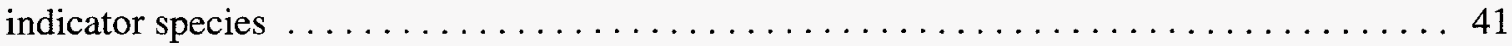

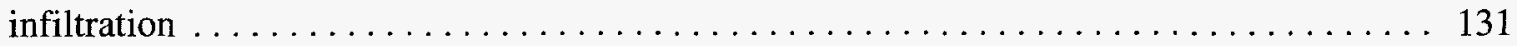

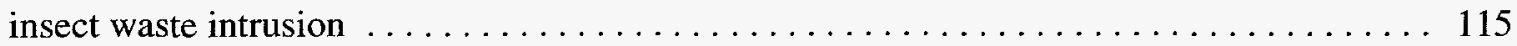

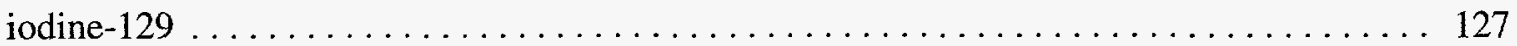

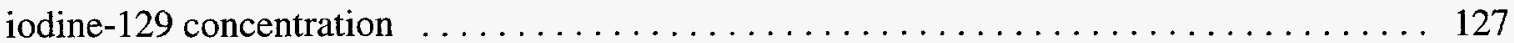

iodine-129/127 ratios . . . . . . . . . . . . . . . . . . . . . . . . . . . . . 127

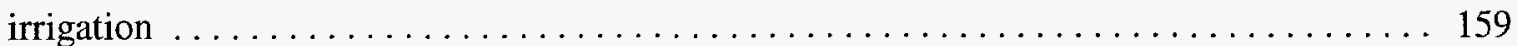

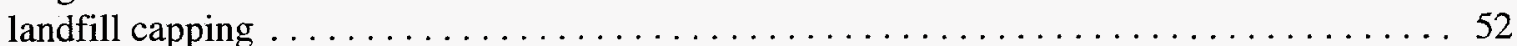

landfill cover . . . . . . . . . . . . . . . . . . . . . . . . . . . . . 154

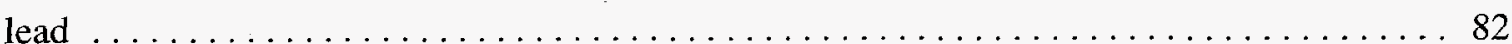

lichens .......................................... 100, 140

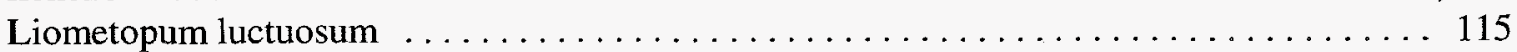

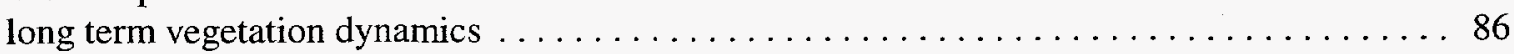

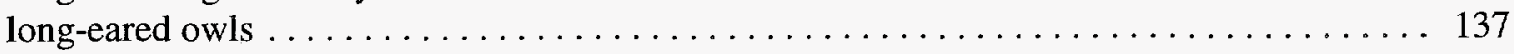

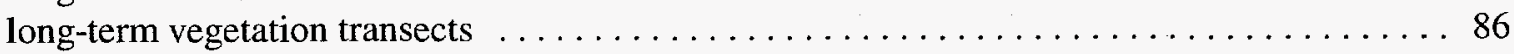

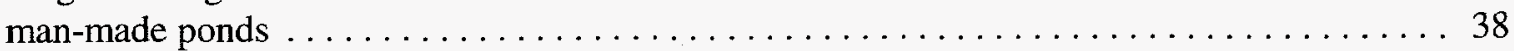

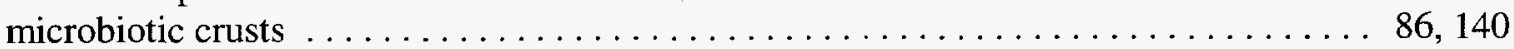

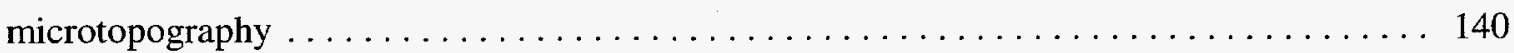

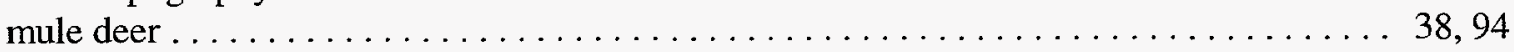

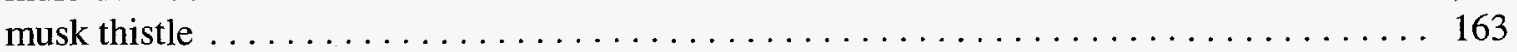

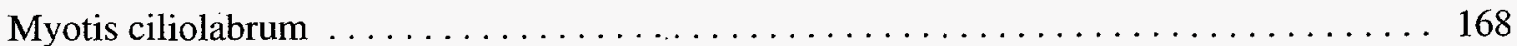

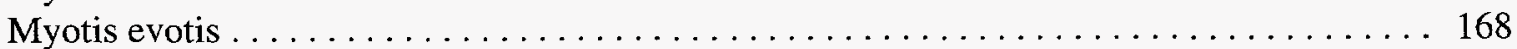

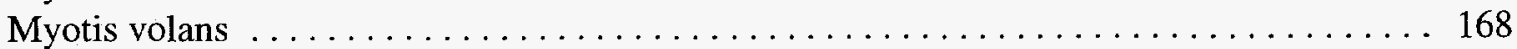




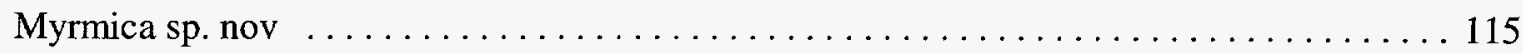

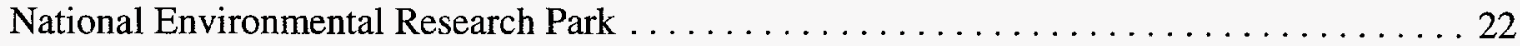

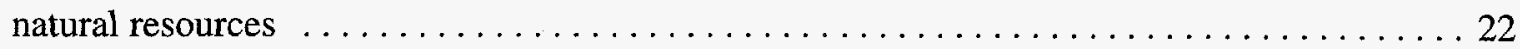

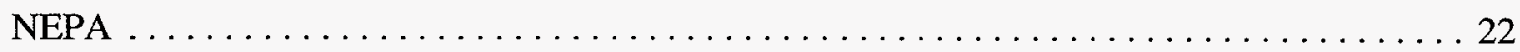

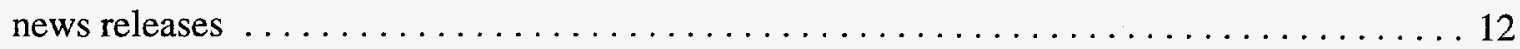

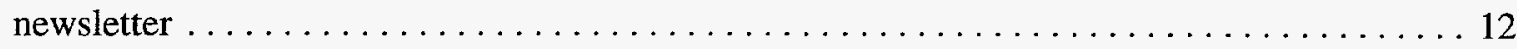

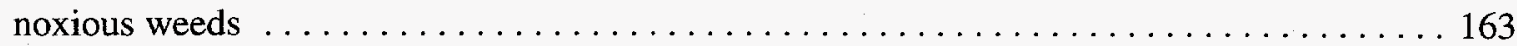

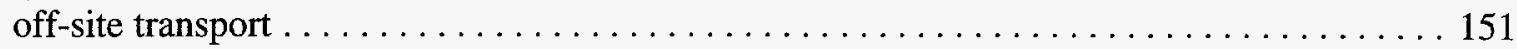

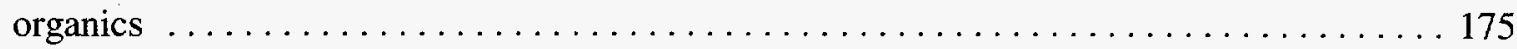

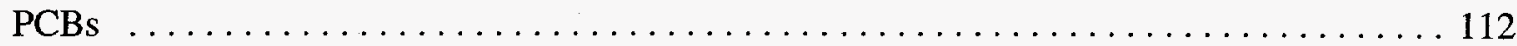

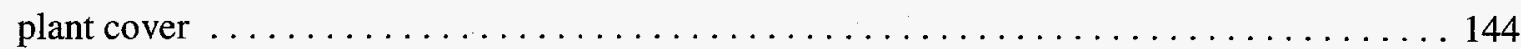

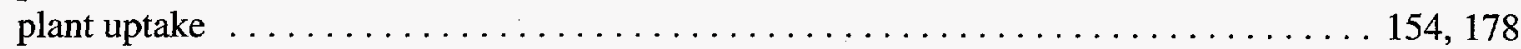

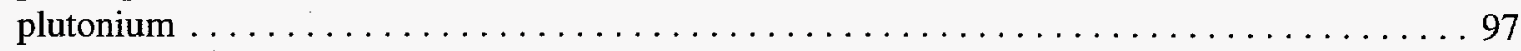

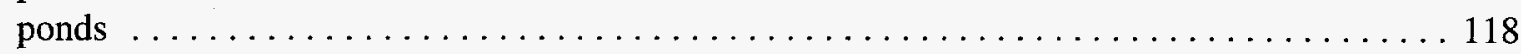

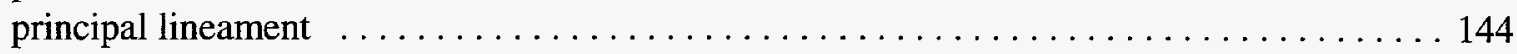

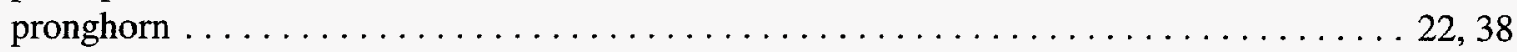

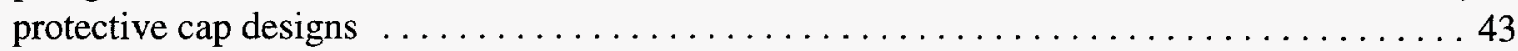

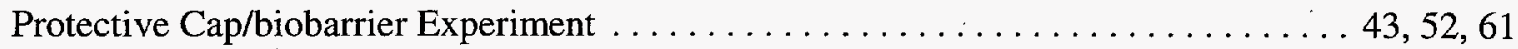

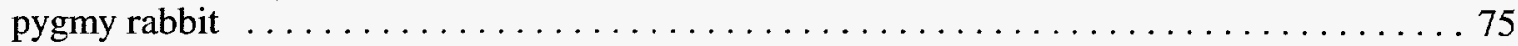

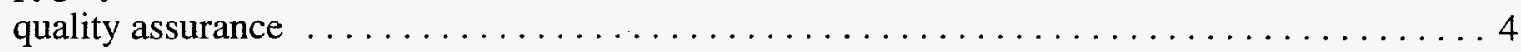

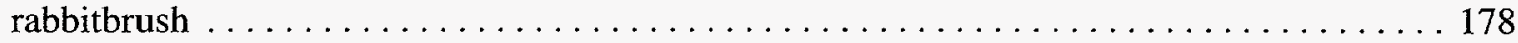

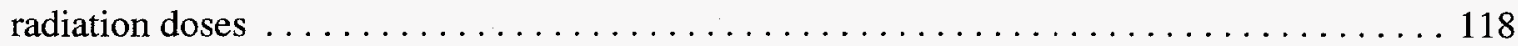

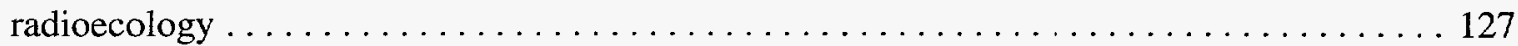

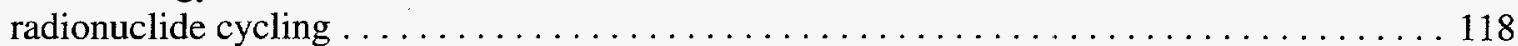

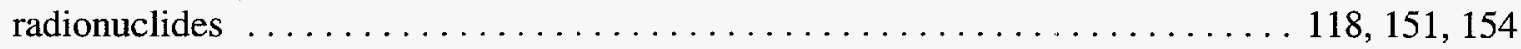

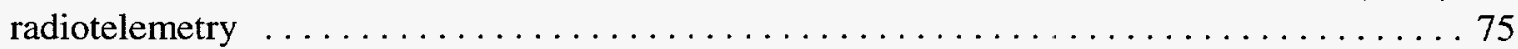

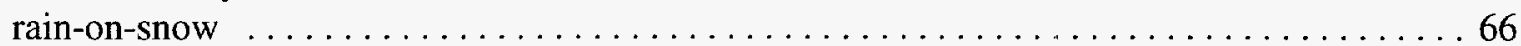

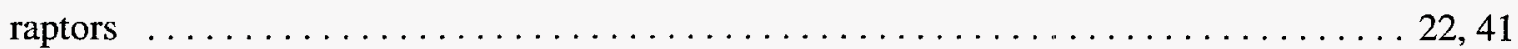

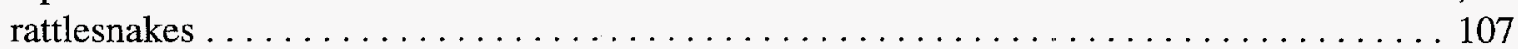

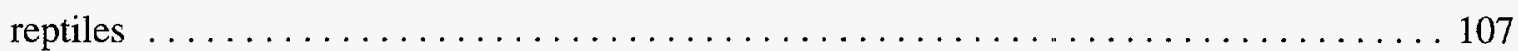

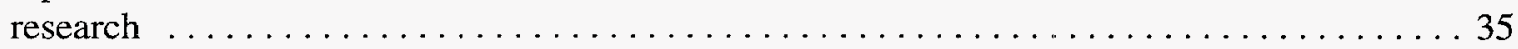

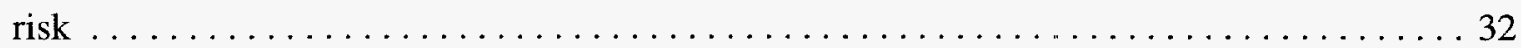

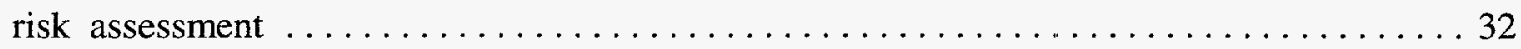

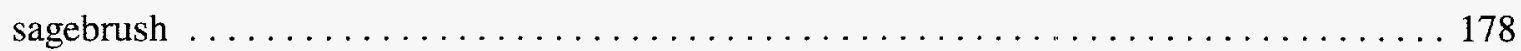

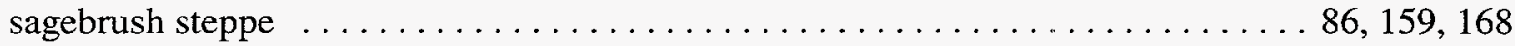

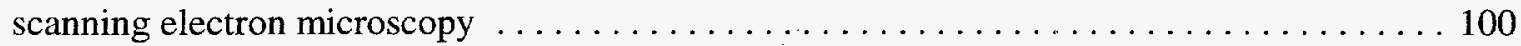

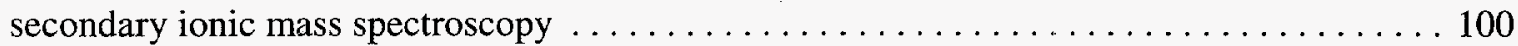

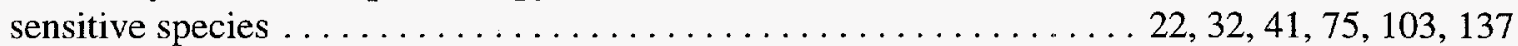

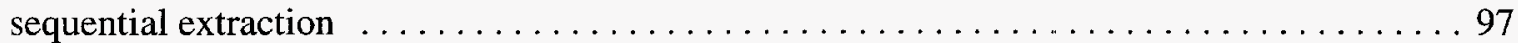

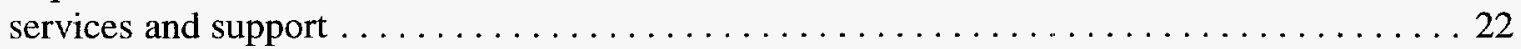

sewage wastewater . . . . . . . . . . . . . . . . . . . . . . . . 159

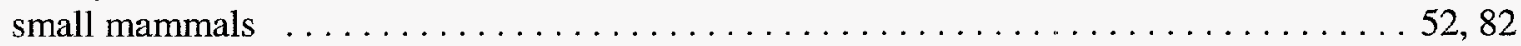

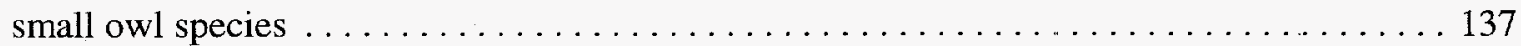

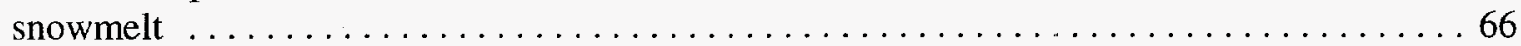

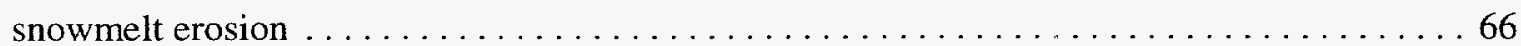

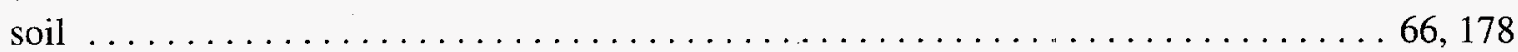

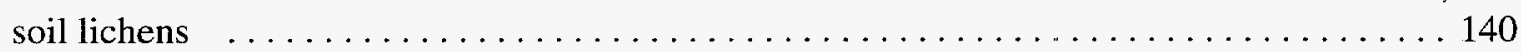

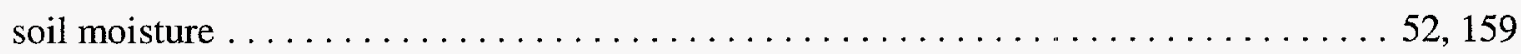




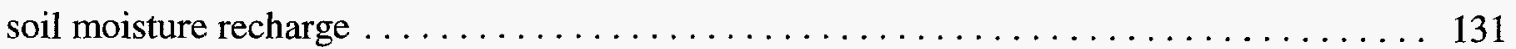

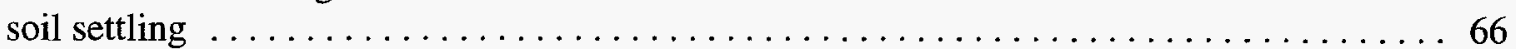

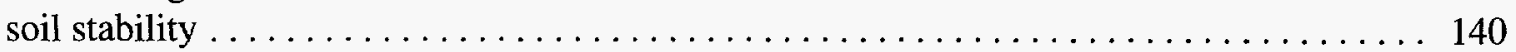

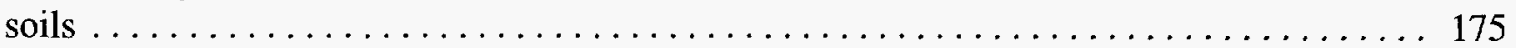

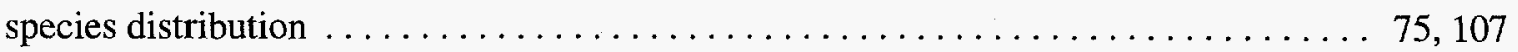

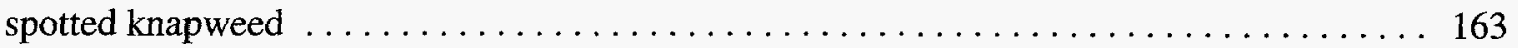

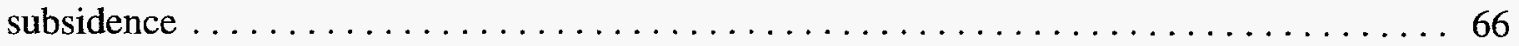

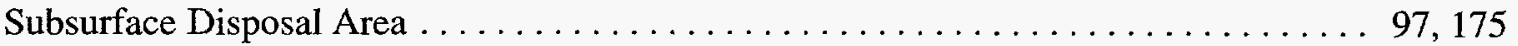

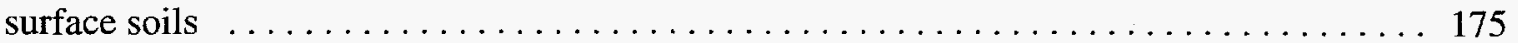

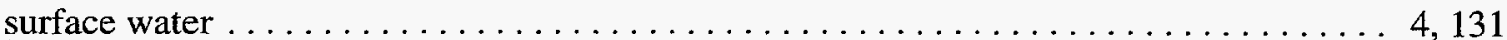

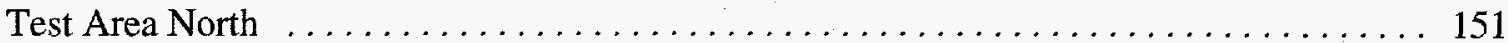

Test Reactor Area ............................. 118, 151, 154

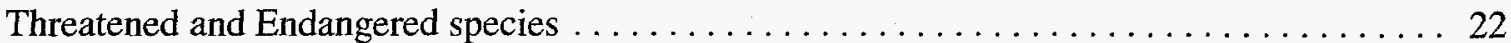

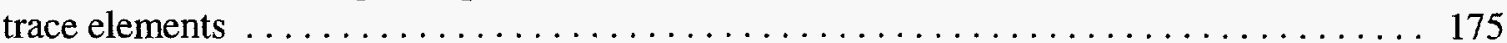

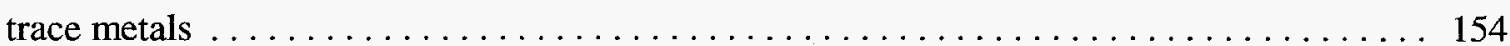

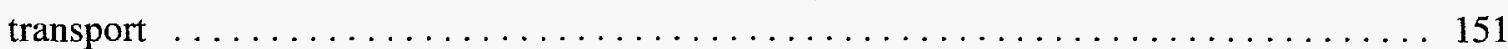

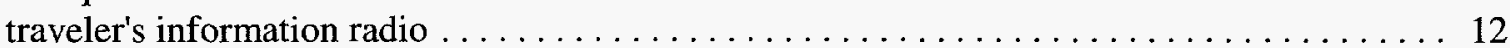

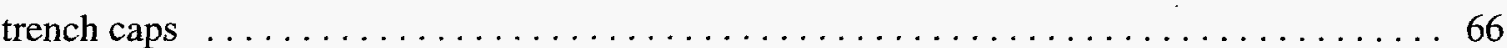

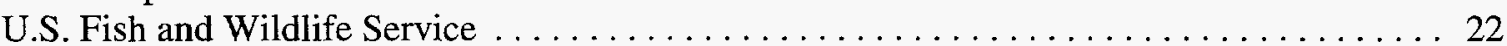

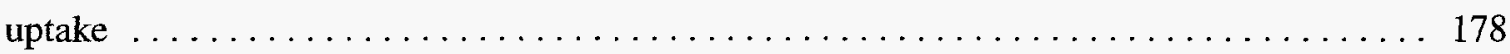

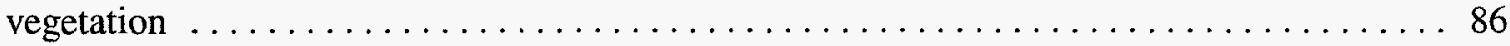

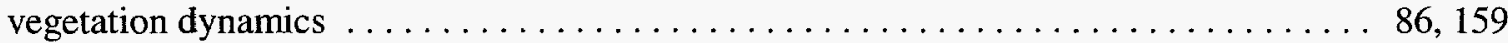

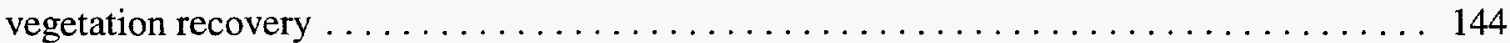

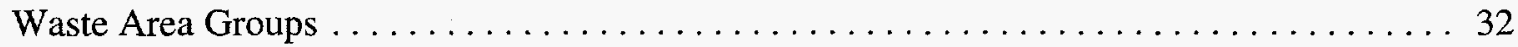

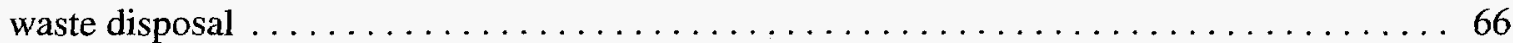

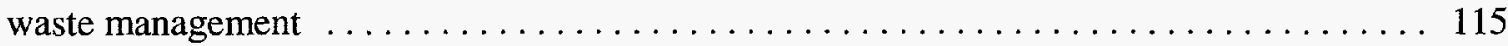

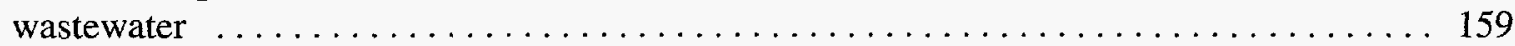

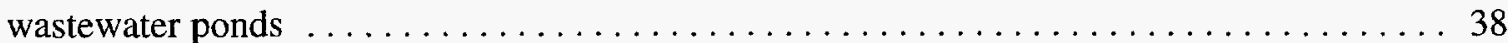

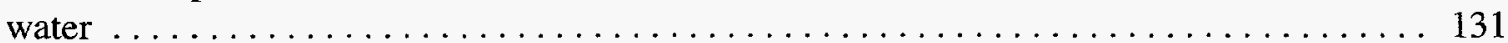

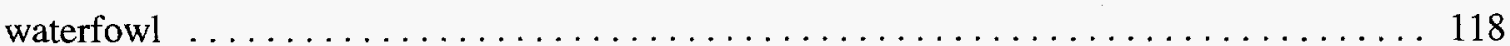

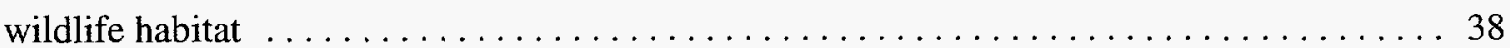

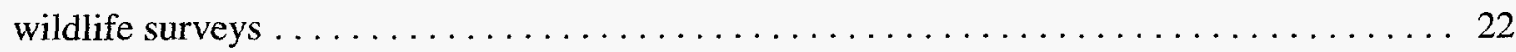

